George Alexandre Ferreira Dantas

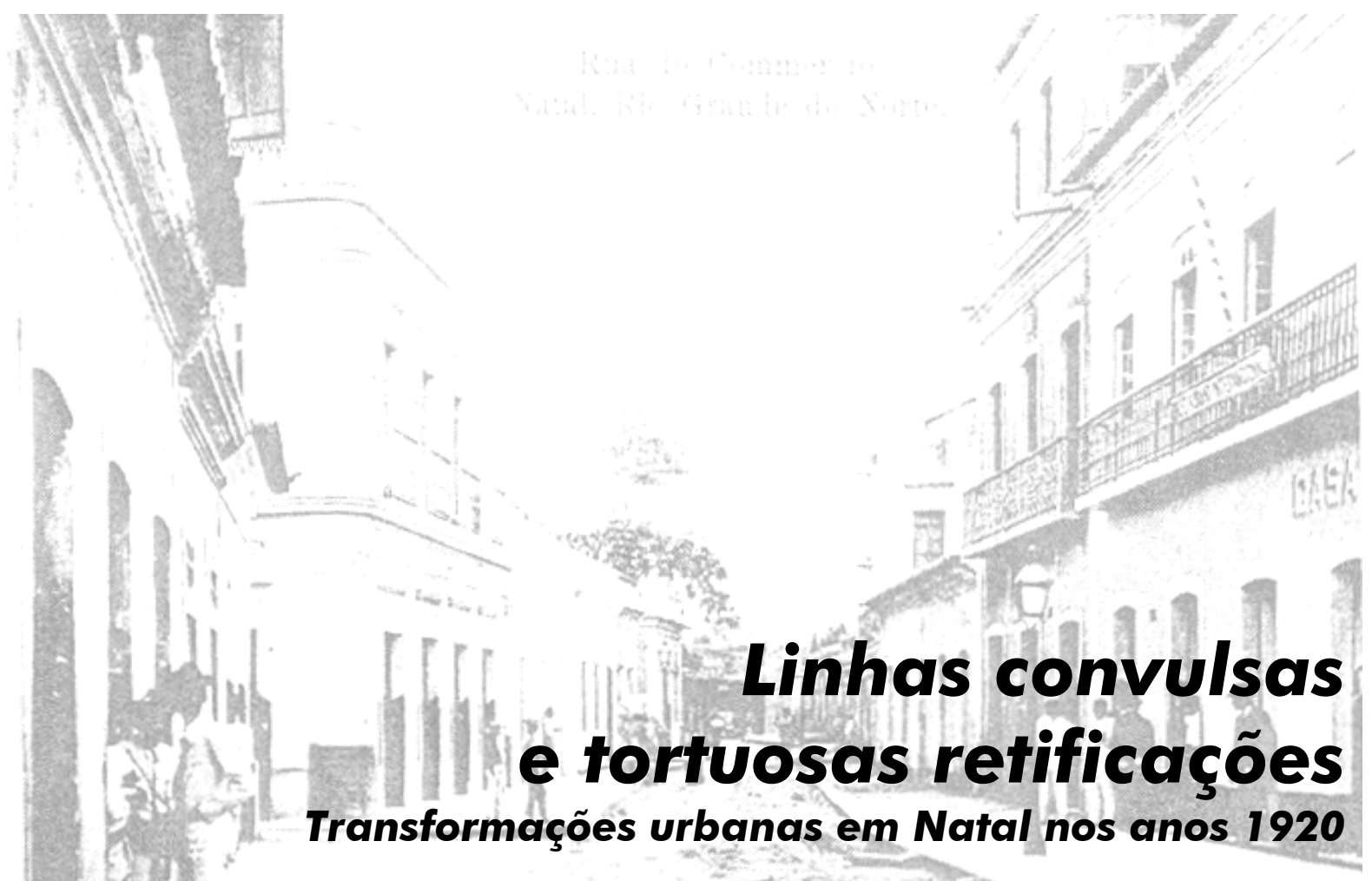


George Alexandre Ferreira Dantas

\section{Linhas convulsas}

\section{e tortuosas retifícações}

Transformações urbanas em Natal nos anos 1920 

Linhas convulsas e tortuosas retificações

Transformações urbanas em Natal nos anos 1920 

UNIVERSIDADE DE SÃO PAULO

ESCOLA DE ENGENHARIA DE SÃO CARLOS

DEPARTAMENTO DE ARQUITETURA E URBANISMO

PROGRAMA DE PÓS-GRADUAÇÃO EM ARQUITETURA E URBANISMO

\title{
Linhas convulsas e tortuosas retificações Transformações urbanas em Natal nos anos 1920
}

\begin{abstract}
Dissertação apresentada ao Programa de PósGraduação em Arquitetura e Urbanismo da Escola de Engenharia de São Carlos - USP, dentro da área de concentração Teoria e História da Arquitetura e do Urbanismo, como requisito parcial para a obtenção do título de Mestre.
\end{abstract}

Candidato: Arquiteto George Alexandre Ferreira Dantas Orientador: Prof. Dr. Carlos Roberto Monteiro de Andrade 
Ficha catalográfica preparada pela Seção de Tratamento

da Informação do Serviço de Biblioteca - EESC/USP

Dantas, George Alexandre Ferreira

D192L Linhas convulsas e tortuosas retificações :
transformaçóes urbanas em Natal nos anos 1920 / George

Alexandre Ferreira Dantas. -- São Carlos, 2003.

Dissertação (Mestrado) -- Escola de Engenharia de São Carlos-Universidade de São Paulo, 2003.

Área: Tecnologia do Ambiente Construído.

Orientador: Prof. Dr. Carlos Roberto Monteiro de Andrade.

1. Urbanismo. 2. História urbana. 3. Modernização. I. Título. 
FOLHA DE JULGAMENTO

Candidato: Arquiteto e Urbanista GEORGE ALEXANDRE FERREIRA DANTAS

Dissertação defendida e julgada em 07-10-2003 perante a Comissão Julgadora:

lauls de thah

Prof. Dr. CARLOS ROBERTO MONTEIRO DE ANDRADE (Orientador) (Escola de Engenharia de São Carlos/USP)
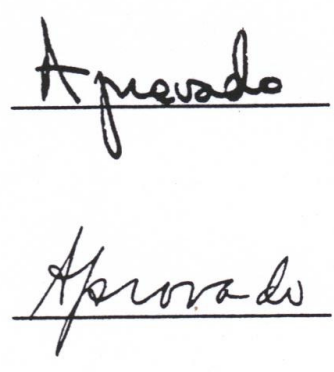

Aprovado

Profa. Tht. MARIA STELLA MARTINS BRESCIANI (Universidade Estadual de Campinas/UNICAMP)

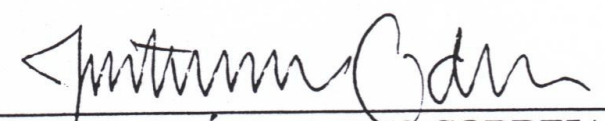

Prof. Dr. JOSÉ TAVARES CORREIA DE LIRA (Escola de Engenharia de São Carlos/USP)

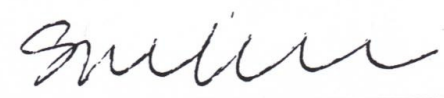

Profa. Dra. SARAH FELDMAN

Coordenadora do Programa de Pós-Graduação em Arquitetura e Urbanismo

Profa. Assoc. MARIA dO CARMO CALIJURI Presidente da Comissão de Pós-Graduação da EESC 


\section{RESUMO}

Esta dissertação discute o processo de transformações urbanas por que a cidade de Natal-RN passou na década de 1920, período decisivo para a conformação de sua estrutura e paisagem modernas. Procurando compreender o contexto político, cultural e social que suscitou o Plano Geral de Sistematização, elaborado pelo arquiteto Giacomo Palumbo entre 1929 e 1930, aborda-se: o processo mais longo de modernização urbana empreendido desde o final do século XIX, apontando a ascensão do olhar técnico, em especial o médico, sobre o espaço urbano; as representações de "crise" urbana que se instauraram em Natal no início dos anos 1920; as narrativas literárias e historiográficas que revelam o esforço pela compreensão dos significados das mudanças que se processavam e, tarefa na qual o papel do intelectual Câmara Cascudo foi fundamental, pela construção da história da cidade; a relação entre saneamento e educação que secundaram as discussões sobre o Plano elaborado pelo engenheiro Henrique de Novaes para Natal, em 1924; a administração municipal do engenheiro Omar O'Grady (19241930) e seu esforço pela racionalização e eficiência das reformas urbanas; o lugar e as influências do Plano de Palumbo no contexto da cultura urbanística moderna gestada no início do século XX; e, por fim, acompanha-se a passagem do "turista aprendiz" Mário de Andrade por Natal entre 1928 e 1929 e a representação de cidade que emerge dos seus relatos, a partir das errâncias pelo espaço tradicional - uma cidade distante das representações apologéticas e oficiais.

\section{Palavras-chave:}

Natal - reformas urbanas - anos 1920 - urbanismo - Omar O’Grady - Giacomo Palumbo Henrique de Novaes - Câmara Cascudo 


\section{ABSTRACT}

This dissertation aims to discuss the process of urban transformations by which the city of Natal has passed in the 1920s. This period was fundamental to conform Natal's modern urban structure and landscape. By intending to comprehend the social, cultural, and political context that foments the Master Plan, elaborated by architect Giacomo Palumbo between 1929 and 1930, it discusses: the urban modernization process that had been developed since last decades of XIXth century, pointing specifically the emerging of a technical approach on urban space; the representations of urban "crise" which marked the history of Natal in the beginnings of 1920s; the literary and historiographical narratives that reveal the efforts for comprehending the meanings of urban transformations and for constructing a history of the city, task in which the intelectual Câmara Cascudo was fundamental; the relations between sanitation and education into the urban plan elaborated by engineer Henrique de Novaes in 1924; the municipal administration of engineer Omar O'Grady (1924-1930) and his efforts to racionalizate and to get efficiency in the urban reforms; the influences and characteristics of Palumbo's Master Plan related to the culture of town planning developed since the beginnings of XXth century. Finally, it discusses the accounts on Natal produced by the intelectual Mario de Andrade in the end of 1920s.

\section{Keywords:}

Natal - urban reforms - 1920s - town planning - Omar O’Grady - Giacomo Palumbo - Henrique de Novaes - Câmara Cascudo 

Per me si va ne la città dolente,

Per me si va ne l'etterno dolore, Per me si va tra la perduta gente.

Dante Alighieri (Inferno, III, 1-3) 



\section{Agradecimentos}

Se é lugar comum referir-se ao caráter a um tempo coletivo e solitário do trabalho de pesquisa, que não escapa à interlocução esclarecedora e perspicaz e nem às incontáveis e angustiadas horas em frente à tela do computador, não deixa de ser por isso menos verdadeiro e importante. Cabe aqui então destacar as pessoas e instituições que me são caras e, de uma maneira ou outra, contribuíram à tessitura desta dissertação:

Ao professor Carlos de Andrade, pela acolhida em São Carlos, pela orientação e interesse vivos, ajuda fundamental na construção desta dissertação, nos seus questionamentos e indagações; aos professores do departamento de arquitetura da EESC-USP, em especial: Cibele Rizek, Hugo Segawa, Mário D’Agostino, Nabil Bonduki, Sarah Feldman e Telma Correia; e os funcionários Geraldo, Oswaldo, Ceneviva, Lucinda e Marcelo Celestini, deslindando, sempre que possível, os meandros burocráticos;

Aos professores José Tavares Correia de Lira (EESC-USP) e Maria Stella Bresciani (IFCH-UNICAMP) pela disposição, cuidado e erudição na leitura e discussão do texto da qualificação, o que possibilitou mudanças importantes para a compreensão da problemática, das hipóteses e saídas a este trabalho;

Aos amigos que ajudaram a dividir esta ingente solidão, cada um a seu modo, com inteligência, paciência e carinho. Em São Carlos, pela leitura e comentários atentos, incisivos e fraternos ao texto: Fernando Atique, Francisco Sales e Martina Acosta; pelo companheirismo e desvelo: Ceila Cardoso, Daniel Maciel, Fabiano Lemes, Gabriella Lima, Paula Sardeiro, Renata Cabral, Renata Macedo, Rosana Steinke, Stella Pugliesi e William Valbuena; pelo convívio, nos corredores, salas e cafés do SAP: Amanda, Cláudia Araújo, Cynthia Aleixo, Gabriela Campagnol, Jefferson, Luana Marelli, Raïssa Alves, Renato Locilento, Rossana Folz e Vanessa; pelas discussões cientificas, filosóficas e, principalmente, mundanas na praça da EESC: Dayse e Fritz Huguenin, Giuseppe Câmara, Hamilton Varela, Valderi Pacheco e Sílvio César; pela alegria de Mirela Macedo, Rodrigo Santana e Sílvia Macedo; ao colega de república André Naleto; e aos amigos de Natal, pela compreensão e força: André Luís e Alândia, Marcos Jr., Mário Március, Raphael Mendonça, Sadi Jr. e Cristina;

Ao grupo de pesquisa História da Cidade e do Urbanismo, do Departamento de Arquitetura da UFRN, pelas discussões, informações, pesquisas, envio de materiais, pela grande e imprescindível ajuda a esta dissertação e, principalmente, pela amizade: em especial à Angela Ferreira, Anna Rachel Baracho e Ana Caroline Dantas, além de Giovana Oliveira, Kleyne Dantas e Alenuska Guimarães, e todos os bolsistas e pesquisadores;

Aos funcionários das diversas bibliotecas e instituições que foram fundamentais a esta pesquisa; em São Carlos: Biblioteca Central da EESC-USP e o Centro de Pesquisa e Documentação do Depto. de Arquitetura e Urbanismo; em São Paulo: Biblioteca Municipal Mário de Andrade, Instituto Adolfo Lutz, Museu de Saúde Pública Emílio Ribas, Instituto de Estudos Brasileiros da USP, Biblioteca de História da FFLCH-USP, Biblioteca Central da Escola Politécnica; no Rio de Janeiro: Biblioteca Nacional, Biblioteca do Clube de Engenharia (à séria e competente Vaneza Fernandes), Instituto de Arquitetos do Brasil, Museu da República; em Natal: Instituto Histórico e Geográfico do Rio Grande do Norte, Arquivo Público Estadual; nos Estados Unidos (by e-mail): Catherine Bruck, do Illinois Institute of Technology (Chicago);

Ao professor Edgard Ramalho Dantas, sempre solícito e interessado nesta pesquisa, e ao seu pai Osório Dantas; à família O'Grady em Fortaleza e no Rio de Janeiro, em especial ao engenheiro Paulo Dantas O'Grady; à generosa acolhida da família de Giacomo Palumbo no Rio de Janeiro, sua filha, Yvette Palumbo, e seu neto, Hélio Eichbauer; 
À FAPESP (processo n. ${ }^{o}$ 99/03345-0), pela bolsa e apoio concedidos à pesquisa, fundamentais para a dissertação ora apresentada;

A toda minha família: Edmundo e Expedita, Leonardo, Suênia e o pequeno Murilo, Gustavo e Cláudio; aos meus sogros, Marcos e Albanita, e a Marcos Jr. e Érika; à acolhida em Campinas de Hélio, Idati, Alex e Sandro; e a todos os outros que, para não sermos injustos, não caberia listar aqui; por favor, sintam-se abraçados;

Aos colegas e amigos professores, funcionários e alunos do curso de Arquitetura e Urbanismo do Centro Universitário de João Pessoa que, neste último ano, foram um apoio e um incentivo importantes: em especial, Amélia Panet, Nilton Santos, Rossana Honorato e todos os outros empenhados na construção de um curso sério;

A Ana Karina, pela sua paciência, compreensão e amor, na ponte entre Natal e São Carlos, ajudando nos gestos materiais e imateriais.

As horas solitárias e os erros e deslizes são de minha responsabilidade.

Natal, Verão de 2003. 


\section{Sumário}

Lista de figuras

Quadros

Siglas utilizadas

Das tais linhas convulsas... (pensando numa introdução)

Capítulo I

Surge et Ambula: “crise" urbana em Natal na virada para a década de 1920

A vaga miseranda passa à porta

Cidade Nova para um novo regime

Representações de "crise"

Capítulo II

Não ha-tal, Natal: movimentos de construção e desconstrução da cidade colonial

1599-1889: uma cidade inexistente

O bonde (ou o "caningado rapa-coco") da História

Fabulações para uma história da cidade (moderna)

Capítulo III

Saneamento e educação no Plano Geral das Obras de Saneamento de Natal (1924)

Esforços de superação da "crise" urbana: 1920-1923

A "pauta modernizadora" do governo José Augusto

Uma nova paisagem para Natal

Capítulo IV

Construindo a cidade: a administração Omar O'Grady (1924-1930)

Capítulo V

“Caes da Europa": um plano para o futuro (1929-1930)

... e das tortuosas retificações (à guisa de conclusão ou nas pistas de um "turista aprendiz") 
O Novo Plano da Cidade - II - A Ribeira no "Master-Plan",L.C. Cascudo

A remodelação de Natal, C. Portinho

185

Os progressos constantes da aviaģão, C. Portinho

186

Excerto do Relatório de 1930 do prefeito Omar O’Grady

188

Resolução n. 304, de 6 de abril de 1929

190

Termo do contrato entre a Prefeitura de Natal e Giacomo Palumbo 


\section{Lista de Figuras}

\section{Caderno de imagens I}

Figura 1-01: Veroveringe van RIO GRANDE in Brasil. anno 1633

Figura 1-02: Natal em $1864 \quad \mathbf{8 3}$

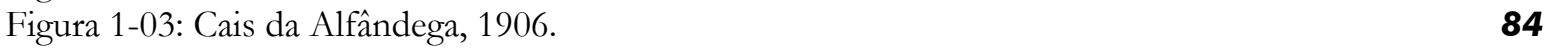

Figura 1-04: Planta da Cidade Nova $\quad \mathbf{8 4}$

Figura 1-05: Praça Augusto Severo $\quad \mathbf{8 5}$

Figura 1-06: Praça Augusto Severo $\quad \mathbf{8 5}$

Figura 1-07: Teatro Carlos Gomes $\quad \mathbf{8 5}$

Figura 1-08: Terrenos de propriedade da ETFL $\quad \mathbf{8 6}$

Figura 1-09: Praça André de Albuquerque $\quad 86$

Figura 1-10: o bonde descendo a Av. Junqueira Ayres $\quad \mathbf{8 6}$

Figura 1-11: A fonte pública do Baldo $\quad \mathbf{8 7}$

Figura 1-12: Matadouro público $\quad \mathbf{8 7}$

Figura 1-13: Isolamento de variolosos São Roque $\quad \mathbf{8 7}$

Figura 1-14: O Paço da Pátria, às margens do Potengi $\quad \mathbf{8 8}$

Figura 1-15: uma vista panorâmica do bairro das Rocas $\quad \mathbf{8 8}$

Figura 1-16: Rua do Commercio, bairro da Ribeira $\quad \mathbf{8 8}$

Figura 2-01: Praça André de Albuquerque $\quad 89$

Figura 2-02: Praça Sete de Setembro $\quad \mathbf{8 9}$

Figura 2-03: Praça da Alegria $\quad 90$

Figura 2-04: Av. Tavares de Lyra $\quad 90$

Figura 2-05: Av. Junqueira Ayres $\quad 91$

Figura 2-06: Av. Junqueira Ayres 91

Figura 3-01: Natal - vista da torre da Inspectoria F. O. Contra as Seccas 92

Figura 3-02: Rocas - Travessa Paraense $\quad 92$

Figura 3-03: Rocas - uma familia $\quad 92$

Figura 3-04: Esboço para o projeto de intervenção no bairro da Cidade Alta 93

Figura 3-05: blueprint do plano de saneamento de 1924

\section{Caderno de imagens II}

Figura 4-01: mapa da cidade de Natal de 1924, organizada pela Comissão de Saneamento de Natal

Figura 4-02: Panorâmica dos bairros da Ribeira e Rocas

Figura 4-03: Oitizeiro

Figura 4-04: Panorama da Barra Dunas e ponte da Estrada de ferro central

Figura 4-05: Praça do Palácio/ Natal

Figura 4-06: Omar O'Grady ante praias/ natalenses $\quad 148$

Figura 5-01: Vista aérea de Natal em 1930

Figura 5-02: Curva do Baldo, início da avenida Rio Branco 149

Figura 5-03: Beires e Castilho, do avião "O ARGOS", com Câmara Cascudo e o engenheiro 150

Omar O'Grady, em 1927

Figura 5-04: inauguração do Aero-Club de Natal

Figura 5-05: Trecho do Plano Geral de Sistematização 


\section{Quadro}

Quadro 01: investimentos (do governo estadual) em Natal em 1910-1911

\section{Siglas utilizadas}

ABL

CSN

ETFL

I(F)OCS

IHGB

IHGRN

RSU
Academia Brasileira de Letras Comissão de Saneamento de Natal Empresa Tração, Força e Luz de Natal Inspetoria (Federal) de Obras Contras as Secas Instituto Histórico e Geográfico Brasileiro Instituto Histórico e Geográfico do Rio Grande do Norte Repartição de Serviços Urbanos 


\section{Das tais linhas convulsas... (pensando numa introdução)}

\begin{abstract}
"Officialmente existe a Cidade do Natal ha tresentos e trinta annos. Relativamente parece com este titulo há oito ou nove annos. Ou melhor, imita cidade recem fundada, se o enviesamento das arterias não denunciasse a velhice". ${ }^{1}$
\end{abstract}

A exemplo de muitos, Luís da Câmara Cascudo não se furtou, ou escapou, de pronunciar ou escrever algo sobre o Plano Geral de Sistematização de Natal, exposto à visitação pública no prédio da Intendência Municipal em outubro de 1929. Vivenciando, e tentando compreender, como poucos, o processo de transformação por que Natal passava nos anos 1920, Cascudo esteve invariavelmente, em maior ou menor grau e mesmo à distância, envolvido com as principais discussões que mobilizaram o meio intelectual, artístico, técnico e político local.

Em meio aos mais variados artigos, desde o debate eminentemente técnico até as colunas sociais e as correspondências ao jornal "A República", os artigos de Câmara Cascudo se destacam e chamam a atenção para uma discussão que, tomando como mote "o novo plano da cidade", articularia também a cultura, a memória e a história de Natal.

As "linhas convulsas" que intitulam esta dissertação são uma das muitas imagens evocadas por Cascudo para falar da cidade em transformação nos anos 1920, processo no qual o plano seria um arremate, um ponto de culminância; sintetizam, de certo modo, uma das representações mais consistentes que se formou sobre o passado colonial das cidades brasileiras e que, no caso de Natal, ajudou a articular uma narrativa sobre a história da cidade que se tornaria hegemônica. A "atitude moderna" do plano de traçar retas, contra os "caminhos tremulos e indecizos das cidades", contra a "tortuosidade das ruas [que lembravam] um delírio de linhas convulsas", 2 marcaria um momento que seria lido depois como crucial dentro do processo mais longo de modernização urbana por que Natal passou desde o final do século XIX e durante as primeiras décadas do século XX.

Tais "linhas", ou, mais ainda, esses artigos de Cascudo, servem-nos portanto como ponto de partida para alinhavar os objetivos e as discussões que estruturaram a redação deste trabalho. Contudo, antes é importante observar que esta pesquisa nasceu antes mesmo do início do mestrado, nas investigações desenvolvidas desde o final do segundo semestre de 1997 (com uma bolsa PIBIC/CNPq vinculada ao departamento de Arquitetura da UFRN) que resultaram na monografia de conclusão da graduação intitulada "Natal, 'Caes da Europa': o Plano Geral de Sistematização no contexto de modernização da cidade (1929-1930)", apresentada em agosto de $1998 .^{3}$

Quais razões motivaram a proposição de um plano urbanístico naquele momento específico do desenvolvimento da cidade, questionava-se então. O plano parecia ter uma existência autônoma, que não se relacionava ou não falava sobre o presente ou o futuro da cidade. Existira como antes existira um "plano" Cidade Nova (1901-04), atribuído ao agrimensor italiano, funcionário da Intendência Municipal de Natal, Antonio Polidrelli, e como depois existiria o "Plano Geral de Obras" (1935-39), do Escritório Saturnino de Brito, isto é, uma seqüência de proposições urbanísticas aparentemente sem maiores ressonâncias para a formação do(s) território(s) da cidade, do seu "espaço real vivido". Sobre o plano

\footnotetext{
${ }^{1}$ Cascudo, 1929b; ao longo da dissertação foi mantida a grafia original dos documentos de época citados.

2 Ibid.

${ }^{3}$ Cf. Dantas, 1998.

${ }^{4}$ Como Rolnik (1992) propõe o conceito de território.
} 
elaborado pelo arquiteto greco-italiano Giacomo Palumbo conhecia-se apenas uma foto de sua planta geral, uma pequena biografia do autor, trechos do termo de contrato entre a Prefeitura de Natal e o arquiteto, e o relatório, de janeiro de 1930, do prefeito e engenheiro Omar O'Grady. ${ }^{5}$

A leitura do periódico A República, ${ }^{6}$ inicialmente compreendendo o período entre 1928 e 1931, foi o procedimento metodológico principal para superar a escassez documental e bibliográfica de então. A partir das páginas do jornal foi possível fazer emergir vários discursos sobre a modernização e sobre os significados de "moderno" - com todas as incongruências, contradições e ubiqüidade que esses termos podem encerrar - para a cidade em construção. Compareciam neste discurso questões, entre outras, sobre os instrumentos de gestão, como o zoning, a taxa de benefício e as city plan comissions, sobre a difusão de uma cultura urbanística norte-americana e européia, e suas ressonâncias nacionais, nas palestras e artigos de Anhaia Mello ou de Alfred Agache, por exemplo, envolvendo diversos intelectuais, políticos e técnicos, incluindo aí O’Grady e Palumbo, em entrevistas ou em artigos de punho próprio, enfim, das proposições urbanísticas e do processo de reforma e modernização urbanas que foram articuladas em torno da idéia de Natal como "Caes da Europa", (o que seria) o ponto central de um sistema tri-continental da aviação comercial, a "sala de visitas" do Brasil.

Retirava-se o plano de sua aparente autonomia e inseria-o na história da cidade, do seu processo de configuração e transformação urbanas, permitindo desvelar, pelo menos em parte, os discursos que o legitimaram, os interesses que se lhe articularam em torno, as representações e as discussões suscitadas. Se for possível falar em méritos dessa primeira pesquisa, eles estarão neste "entrar a cidade" e na emergência de personagens outros que não apenas o arquiteto, o autor do desenho para uma cidade de cem mil habitantes e em expansão.

Daí, portanto, a importância da discussão sobre a administração municipal do engenheiro O'Grady (de novembro de 1924 a outubro de 1930), das suas relações, institucionais e familiares, com a estrutura de poder baseada na cultura econômica do algodão da região do Seridó, em geral, e com a administração do presidente do estado Juvenal Lamartine (de janeiro de 1928 a outubro de 1930), em particular, e da confluência entre os ideários ou culturas urbanísticas americana e européia, sintetizada na figura desses dois profissionais: O'Grady e Palumbo. Este era o ponto de partida proposto para estabelecer uma discussão acerca da influência de suas formações e atuações para a configuração do espaço da cidade, do cotejo entre o projeto e o realizado (e do que pode falar o realizado e o apenas projetado), e das questões mais abrangentes sobre o processo e os mecanismos de transferência, tradução e interpretação deste ideário urbanístico à realidade brasileira.

De maneira geral, era a partir de tais questões, então intuídas, inicialmente formuladas ou brevemente respondidas, que se propunha aprofundar e analisar mais detidamente no projeto inicial de pesquisa para o mestrado, todavia ampliando o seu recorte temporal. Isto é, pretendia-se discutir o processo de transformação urbana por que passou a cidade de Natal durante toda a década de 1920, período no qual, escreveria Câmara Cascudo nos artigos já citados, teria finalmente se constituído como tal, superando (e eliminando os resquícios de) os "valores confuzos" herdados do período colonial, cujo maior testemunho estava impresso nas ruas - as "linhas convulsas" - da cidade.

\footnotetext{
5 Estes quatro documentos foram publicados em Miranda (1981); a foto do plano foi tirada na década de 1960 a partir da cópia do original que ficava exposto no prédio da Prefeitura até antes de ser destruída por um dos prefeitos biônicos, ironicamente um arquiteto, que passou pelo cargo neste período; agradecemos aqui ao Grupo de História da Cidade e do Urbanismo (Darq/UFRN) pelo acesso aos originais do relatório e do contrato, que disponibilizamos em seus trechos mais importantes (ver anexos), e ao sr. Edgard Dantas pela cessão de um foto mais nítida obtida a partir do original do plano, onde se pode observar mais detalhes.

${ }^{6}$ Fundado em julho de 1889, como instrumento de propaganda do partido republicano local, logo tornou-se "Órgão dos poderes do Estado" e diário matinal onde trabalharam e escreveram diversos intelectuais e políticos locais proeminentes na Primeira República, como Pedro Velho, Alberto Maranhão, Juvenal Lamartine, Manoel Dantas e Câmara Cascudo; no final da década de 1920, era o único periódico de circulação diária no estado.
} 
Embora seja uma abordagem legítima, dentro dos meandros de uma "história do urbanismo", o centro da análise na atuação de O'Grady e Palumbo não contemplaria mais a necessária abrangência para pensar uma "história urbana" dos anos 1920, para compreender o processo de configuração urbana nesta década, que, afinal, é o objetivo central da pesquisa. Diga-se isto não apenas pelo seu desenvolvimento durante o período de realização do mestrado, com a ampliação do banco de dados do jornal A República, a inclusão de outros importantes periódicos, como o Diário de Natal e A Imprensa, a pesquisa em e a "descoberta" de novos documentos e acervos, mensagens de governo, livros, plantas, planos, iconografia e depoimentos, mas pela tentativa de pensar um novo olhar, uma nova leitura, estabelecer um outro "diálogo" com estas fontes primárias e secundárias, qual seja, a princípio, não os considerar apenas como um aporte documental à época, mas, ao contrário, considerá-las dentro de um "projeto" de construção historiográfica e de uma série de representações sobre a cidade que foram mobilizadas para justificar e explicar as intervenções sobre o espaço urbano.

É claro que há uma série de meandros, interesses, intermediações, conscientes ou não, diretas ou não, entre as representações da cidade, os projetos elaborados, as intervenções realizadas e a forma urbana, que devem ser compreendidas (quando possível e mesmo em parte) antes de se estabelecer qualquer ilação.

As "linhas", ou melhor, os artigos escritos por Cascudo sobre o Plano Geral de Sistematização, embora se permitam considerações sobre a cultura urbanística - como quando cita Unwin, Steinhoff, o zoning, a "arte cívica" e o pragmatismo dos técnicos norte-americanos ${ }^{7}$ -, abriram-no principalmente para o debate cultural sobre a cidade em transformação. Nessa operação inversa, o plano foi tomado, não só por Cascudo, como uma possibilidade, concreta, de atualizar o espaço da cidade frente às necessidades dos novos tempos; como o contraponto necessário - de ordem, regularidade, beleza, salubridade, previsão, modernidade - ao que significavam tais "linhas". Os significados do plano se estendem assim para além das representações técnicas daqueles que o formularam; imbricam-se às aspirações pela construção de uma cidade moderna.

Assim, o plano consubstanciaria - e esta é uma das hipóteses centrais desta pesquisa - os esforços de modernização urbana defendidos e empreendidos pelas elites locais desde o final do século XIX e, em especial, ao longo da década de 1920. A centralidade do plano nesse processo só pode ser compreendida portanto se articulada às discussões, às propostas e às intervenções, aos desenhos, planos e "projetos" que o antecederam.

Nesse sentido, o capítulo I discute o conjunto de representações - que tematizaram uma "crise" urbana em função do quadro de fragilidade dos equipamentos e da inconstância no fornecimento dos serviços urbanos - que marcaram as discussões sobre Natal na virada para os anos 1920 e, principalmente, fundamentaram os discursos que apontavam para a necessidade de retomada de um "projeto" de modernização da cidade; em seu bojo, aborda a emergência de um olhar técnico sistematizado sobre o espaço urbano, a partir da publicação da topografia e geografia médicas de Januário Cicco, em 1920. Esse documento possibilitou estabelecer uma discussão que interpelasse não somente essas representações de "crise", mas, principalmente, os "projetos" de reforma urbana empreendidos desde a segunda metade do século XIX - que tinham como eixo o combate à insalubridade e a modernização econômica do estado.

Concomitante à "desconstrução" física da cidade colonial, uma série de leituras se formaram e, mais do que ajudar a explicar essas transformações, construíram os próprios significados desse processo. A formação de uma narrativa hegemônica sobre a história de Natal - cuja interpretação chave baseia-se na construção da imagem de uma cidade inexistente durante o período colonial - é o tema do capítulo II. Como será discutido, ao se apropriar da

${ }^{7}$ Cf. Cascudo, 1929c. 
tradição intelectual local - que já mobilizara uma série de temas caros ao pensamento social brasileiro para discutir a cidade -, ao trabalhar os documentos do período colonial, em especial os relatos dos viajantes, e ao se envolver com as lides do ambiente cultural dos anos 1920, Câmara Cascudo se tornaria o principal artífice dessa História. Narrativa na qual a década de 1920 se afigura como central para entender a construção da cidade moderna.

Aqui, a noção de representação como prática ${ }^{8}$ foi importante para estruturar essa discussão, identificando, ou problematizando, o lugar social e cultural de quem produz o discurso, a narrativa; mais ainda, os discursos não apenas representam o real, mas o instituem ${ }^{9}$ a partir da sua própria lógica operativa, dos seus sistemas de classificação e delimitação (e exclusão, como afirma Foucault), que estabelecem o que é válido ou não, o que é verdadeiro ou não. "... o discurso não é simplesmente aquilo que traduz as lutas ou os sistemas de dominação, mas aquilo por que, pelo que se luta, o poder do qual nos queremos apoderar”. ${ }^{10}$

Os capítulos seguintes tomam como eixos os fatos e acontecimentos da história da disciplina urbanística na década em questão para discutir como a cidade foi pensada, interpretada, tomada como objeto dos vários saberes que se lhe debruçaram sobre; servemnos como pontos de inflexão para entender os processos mais amplos de transformação urbana. Esse procedimento metodológico de abordagem reconhece, a partir de Tafuri, que é possível "realizar uma análise puramente lingüística de assentamentos como Radburn ou como as Green belt cities do New Deal Americano. Contudo, um método com este [...] resultaria inadequado para colocar aquelas propostas em seu próprio contexto". "Mesmo assim, deve-se ressaltar que as propostas propugnadas pelo saber urbanístico não surgem como mera conseqüência do ambiente social, político e/ou cultural. Ele introduz novos elementos ao debate, influi na forma de olhar, pensar e estruturar a cidade.

Assim, no capítulo III, discutem-se os esforços pela superação do quadro de "crise" urbana dos anos 1920 que, secundados pelas discussões em torno da importância da educação e do saneamento para a construção de uma nação moderna, culminariam na elaboração do Plano Geral das Obras do Saneamento de Natal, realizado sob a coordenação do engenheiro Henrique de Novaes, em 1924. Esse, que seria o primeiro plano de fato realizado para Natal, não se concretizaria, apesar da busca das condições materiais de exeqüibilidade que marcou a sua proposição, mas se constituiria em um importante marco para os debates técnicos que se seguiram.

De fato, o conjunto de estudos e proposições levados a cabo pela equipe chefiada por Novaes seria uma base fundamental para a gestão do engenheiro Omar O'Grady (19241930). Assim, ao lado dos esforços pela reestruturação administrativa da Intendência e pela autonomia financeira do município, esse período marcaria a emergência da instância municipal como uma voz ativa e atuante no processo de transformações urbanas de Natal. Como será discutido no capítulo IV, a figura profissional de O'Grady é determinante para entender a rearticulação de um projeto de modernização urbana na década de 1920.

Projeto esse que, na confluência de todos esses eventos e processos, seria finalmente consubstanciado no Plano Geral de Sistematização, elaborado pelo arquiteto greco-italiano Giacomo Palumbo entre 1929 e 1930. O capítulo V discute as possíveis filiações do plano ao ideário cidade-jardim, como o considerariam alguns escritos da época, e, assim, põe em pauta o tema da difusão e ressonância de modelos urbanísticos no Brasil.

Por fim, acompanhamos, ainda que brevemente, a passagem do "turista aprendiz" Mário de Andrade por Natal, em fins da década de 1920; as discussões e descrições sobre a cidade produzidas por esse observador privilegiado, cujas "portas" da cidade foram

8 Cf. Chartier, 1990.

9 Albuquerque Jr., 2001, p.23.

${ }_{10}$ Foucault, 2002, p.10.

11 Tafuri, 1984. 
franqueadas por personagens como Câmara Cascudo, Omar O’Grady e Antônio Bento, permitem-nos sondar alguns dos muitos significados que esse processo de transformação suscitou para o tecido social, e não apenas físico, da cidade.

Cabe ainda destacar três vínculos de pesquisa que foram fundamentais ao desenvolvimento desta dissertação: 1) a aprovação do projeto de pesquisa de mestrado pela FAPESP em outubro de 1999 (processo n. 99/03345-0), o que possibilitou, entre outras coisas, a realização de viagens a São Paulo, Rio de Janeiro e Natal, o acesso a novos acervos (em especial o da Biblioteca Nacional, no Rio de Janeiro), a realização de entrevistas e a ampliação de bibliografia atinente; 2) no âmbito da pesquisa "Habitação social e arquitetura moderna no Brasil (1930-1965)" do grupo Arqhab (coordenado pelos professores Carlos de Andrade, Nabil Bonduki e Sarah Feldman), o levantamento do material concernente à produção imobiliária estatal e à legislação urbanística de Natal permitiu coligir boa parte das leis referentes ao espaço urbano de Natal no período, o que mostrou a institucionalização do Plano Geral de Sistematização na forma de baliza legal ao crescimento da cidade até 1947, pelo menos, e a permanência do Código de Obras, promulgado por O'Grady em 1929, até outubro de 1964, quando foi substituído pelo Código de Urbanismo e Obras da Prefeitura do Recife, de 1961, até que fosse confeccionado um novo para Natal (o que ocorreria em 1969); e 3) a troca de dados e informações e a discussão de temas conexos, assim como a coleta, elaboração e formatação de um banco de dados de periódicos e de iconografia para a pesquisa "Modernização e Configuração Urbana: um estudo sobre as transformações da cidade de Natal (1889-1945)", junto ao grupo de pesquisa de história da cidade e do urbanismo do departamento de arquitetura da UFRN (coordenado pela prof. a Angela Ferreira). 


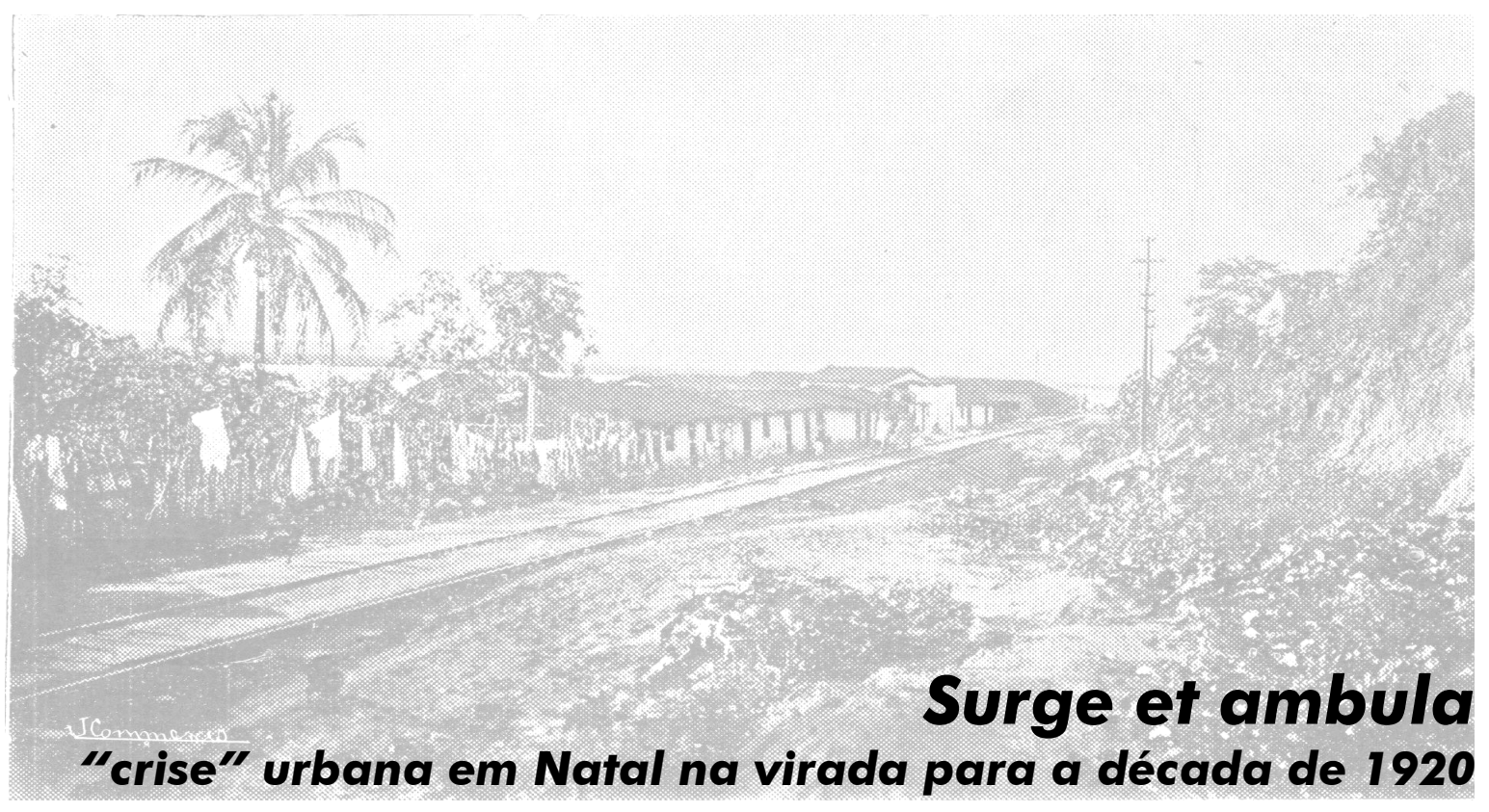


A afirmação de um clima benfazejo, que se impunha aos males dos homens, às suas "orgias de mil pecados, sem remissão e sem remédio", é central na leitura que o médico Januário Cicco fez sobre Natal e as endemias e epidemias que vicejavam em seu espaço urbano. Retomando alguns elementos constitutivos da medicina social e da discussão higienista e sanitarista sobre as cidades, Cicco inscrevia-se assim nos meandros de uma disputa que buscava justificar e legitimar o saber, os discursos e as práticas de um conjunto de intelectuais e profissionais - principalmente médicos e engenheiros - que secundaram ou mesmo lideraram, imiscuídos na estrutura de poder da República Velha, a busca deste tema obsessivo à época: o progresso. ${ }^{1}$

\footnotetext{
"Natal é a cidade mais saudavel do Norte do Brazil. Á margem do oceano e cercada por montanhas de areia ou dunas, cobertas de exuberante vegetação, é batida pelo vento éste-sueste constante e moderado, trazendo á cidade as riquezas de um ar marinho, leve, puro e tonificador. De clima temperado, a sua temperatura não excede de $32^{\circ}$ á sombra". ${ }^{2}$
}

Assim Januário Cicco, formado pela Faculdade de Medicina da Bahia em 1906, iniciava a sua topografia e geografia médicas para Natal, publicadas em seu livro "Como se Hygienizaria Natal", de 1920. Ocupando alguns dos principais cargos da área da saúde na cidade nesse período - era Inspetor da Saúde do Porto, chefe das clínicas do Hospital de Caridade Jovino Barreto e médico da Empresa Tração, Força e Luz -, Cicco transitava por diversas áreas e esferas de governo e poder que lhe permitiam uma visão abrangente da cidade, diretamente ligado às questões que hoje poderiam ser chamadas urbanas. Tais questões, para Cicco, "reclamam o nosso empenho, appellam para o nosso patriotismo, exigem mesmo o nosso sacrificio, desafiam os nossos creditos de gente civilizada, cuja cultura se méde tambem pelas condições de vida de que nos cercamos". ${ }^{3}$

Vinculando diretamente a problemática da saúde pública às reformas urbanas e, conseqüentemente, a um projeto de modernização social e econômica, a descrição, a narrativa e o diagnóstico construídos pelo médico Januário Cicco estabelecem, para o pesquisador atual, um importante documento sobre a cidade de Natal na virada para os anos 1920. Mais ainda, por ser um texto crítico e propositivo para uma cidade que já havia passado por um primeiro

\footnotetext{
1 Cf. Telles, 1999; Bresciani, 1998; Herschmann, 1994. Otília Arantes lembra que, "em país dependente e de capitalismo periférico, o moderno é uma obsessão nacional, entendido via de regra como esforço de atualização, sendo o metro a evolução das sociedades centrais. Modernizar-se - dos hábitos de consumo até os sentimentos estéticos - era condição de formação nacional, redenção do passado colonial etc" (1998, p.37).

2 Cicco, 1920 , p.07.

3 Ibidem, p.39.
} 
ciclo de reformas urbanas, permite entender, balizar e discutir as diversas representações que procuraram denunciar, tornar visível e, de certo modo, problematizar o quadro de fragilidade dos serviços e equipamentos urbanos e a constante ameaça de colapso no seu funcionamento na virada para a década de 1920.

Quadro que, desde a inconstância dos serviços de abastecimento d'água e de energia elétrica, dos atrasos constantes na circulação dos bondes, da precariedade do calçamento e da insuficiência da coleta do lixo, até a falta de hábitos higiênicos, de educação alimentar ou mesmo de regras de comportamento - no teatro, na biblioteca, nos bondes, nas ruas, nas praças e passeios públicos -, ilustrou e conformou todo um conjunto de temas que foi mobilizado para estabelecer novas bases e questões que justificassem e reestruturassem as reformas urbanas que se julgavam e se defendiam como necessárias à cidade. Uma constante na imprensa periódica local desde meados da década de 1910, pelo menos, essas representações de uma "crise" urbana são, portanto, um ponto de partida para compreender o projeto de modernização para Natal articulado durante os anos 1920.

Afinal, para além das discussões sobre a insuficiência técnica da Usina elétrica do Oitizero, sobre os atrasos e os constantes descarrilamentos dos veículos do bonde devido às linhas mal conservadas ou mesmo sobre a (falta de) qualidade da pavimentação urbana, o que estava em questão era a condição "moderna" de Natal ou, mais ainda, a sua condição mesma de cidade. Sucumbir a esse quadro significava assistir a perda dos signos urbanos modernos havia pouco e mal-e-mal instaurados e, pior, voltar à condição de atraso e ignorância que marcara a vida urbana de Natal no período pré-republicano. O quadro de fragilidade dos serviços e equipamentos urbanos era formulado, de fato, como uma situação-limite que, assim, reclamava urgência na resolução dos problemas. Como diria Manoel Dantas, em um artigo de 1921 sobre "os serviços da cidade":

\footnotetext{
"Ao governador deve ser oferecido pela intendencia, commercio e população de Natal todo o concurso possivel até com sacrificio, para a reabilitação dos serviços publicos municipais de luz, força, viação e abastecimento d'agua. [...]. Os effeitos da desorganização dos serviços estão se fazendo sentir na cidade, com uma evidência alarmante. Retrocedemos a olhos vistos. [...]. A realização dos serviços de tracção, luz e esgotto é uma necessidade inadiável, porque, ou a cidade melhora os seus serviços, sobretudo os de tracção, agua e luz, on a cidade morre que em tanto importa a perda de sua atividade". ${ }^{4}$
}

Contundente, o artigo de Dantas exprime com clareza e angústia a incerteza, os impasses e a forma como os problemas eram enunciados e conformavam a discussão sobre a cidade. Entretanto, tais palavras não eram apenas peça de retórica de um dos publicistas locais mais articulados, entusiasta do processo de modernização de Natal e partícipe na construção da história da cidade; ${ }^{5}$ baseado num relatório elaborado pela Comissão de Urgência convocada pelo governo estadual e composta pelos engenheiros Henrique de Novaes, Décio da Fonseca e Borges de Mello para avaliar as condições e apontar soluções para os serviços e equipamentos urbanos de Natal nesse mesmo ano -, o artigo revela a influência crescente do olhar técnico sobre a cidade e marca, outrossim, um momento de mudanças que acarretariam - no que nos interessa discutir mais de perto - a reorganização completa dos serviços urbanos e a criação da Comissão de Saneamento de Natal, em 1924, responsável pela elaboração do Plano Geral das Obras de Saneamento da capital. Momento em que o discurso técnico enfatizaria, cada vez mais, a indissociabilidade da formulação de um projeto de modernização para a cidade da consecução das redes técnicas dos serviços urbanos, em especial do saneamento.

\footnotetext{
${ }^{4}$ Dantas, M., 1921, p.01, grifos nossos.

${ }^{5}$ Sobre Manoel Dantas e o seu papel na construção da história de Natal, veja-se o capítulo II.
} 
Pretende-se, portanto, discutir neste capítulo o contexto de formação das representações desse quadro de precariedade dos serviços e equipamentos urbanos e, no seu bojo, a emergência de um olhar técnico sistematizado sobre a cidade e seus problemas, como o demonstra, por exemplo, o livro do médico Januário Cicco. Para tanto, cabe antes discutir, mesmo que de forma resumida, alguns temas que marcaram as propostas anteriores de transformação da cidade e que podem ser estruturados em dois eixos: as formulações em torno do combate à "cidade insalubre" e as propostas de modernização econômica que visavam transformar Natal em uma cidade de fato.

\section{“... tem sido pouco satisfactorio o estado sanitario da nossa capital"}

As primeiras propostas de reformas urbanas para Natal seriam estruturadas principalmente no contexto de combate à falta de salubridade de seu espaço urbano, suas causas, efeitos e representações, baseadas no pensamento higienista eivado na "teoria miasmática"; " seria também o mote dos discursos e das práticas que, de forma acerba e explícita com a ascensão da República, proporiam a superação da imagem de atraso e da estrutura da velha e insignificante, como se afirmava, "aldeia" colonial e a construção da cidade moderna. Com efeito, este seria o eixo central das normativas e das propostas de transformação do espaço urbano de Natal até o início da década de $1920{ }^{7}$

Mais ainda, seria por meio do discurso técnico, em especial e primeiramente o médico, que a cidade e os seus problemas se fariam visíveis, dizíveis. Não mais o registro estratégico-militar (apontando, principalmente, a localização do Forte, e o número de habitações, soldados, homens e armas) do século XVII, os apanhados administrativos dos funcionários reais da Colônia ou o diletantismo, a curiosidade pelo pitoresco ou o cientificismo naturalista de alguns viajantes estrangeiros do início do XIX; agora o espaço urbano começaria a ser esquadrinhado, assim como os costumes de sua população, com o objetivo de estabelecer as causas para a insalubridade e a irrupção de epidemias e endemias.

O relato do médico do Partido Público, incluído na mensagem do governo provincial de 1851, é um dos primeiros, se não o primeiro, "diagnóstico" sistematizado e, sem dúvida, de pretensões mais abrangentes na leitura da cidade, e na qual a questão do clima configurava-se um ponto de partida para entendê-la.

\footnotetext{
"Esta cidade vantajosamente situada muitos metros a cima da superficie do mar, circumstancia que faz ser menos intenso o calor, apesar de sua latitude constantemente lavada pelos ventos, que sopram diariamente de terra para o mar, e vice-versa, e bafejada quando cresce temperatura pela briza do Oeste, que refresca o ar e o purifica, possúe um clima saudavel, que não favorece o desenvolvimento de epidemias que em outros climas menos felices deterioram a saude e aniquilão a vida". 8
}

Se o clima local não condenava a saúde da cidade a priori, seria o exame minucioso, a partir da ótica do pensamento higienista, de todos os elementos naturais - lagoas, fontes, ribeiras - e aqueles construídos pelo homem - matadouros, mercados, cemitérios, etc. -, assim como das próprias condições de vida e habitação da população, que apontaria as razões do "desequilíbrio do estado sanitário" da cidade. A discussão sobre a epidemia de bexiga, que se propagara dois anos antes e deixara um saldo de mais de 150 óbitos em Natal, revela a relação

\footnotetext{
6 Sobre a introdução do pensamento higienista no Brasil, Cf. Andrade, 1992, Abreu, 1997, e Gunn, 1998, dentre outros estudos.

${ }^{7}$ Sobre a história da higiene urbana e do saneamento em Natal, Cf. Ferreira et al., 2003 (livro que aguarda publicação, no qual participei como pesquisador e co-autor).

${ }^{8}$ Wanderley, 1851, p. 11.
} 
de determinação entre o meio e as (más) condições de vida da população, o que se sobrepunha inclusive às benesses do clima - um dos temas centrais presente nas formulações e polêmicas dos intelectuais no século XIX: ${ }^{9}$

\begin{abstract}
"A epidemia de bexiga, que ultimamente se grassou nesta cidade, nada prova contra a bondade do seu clima; por quanto é facto verificado que ella fora importada de Pernambuco por um soldado, que de la viera; e, si tanto durou foi porque sahindo do Quartel Militar, onde fizera as primeiras victimas, deixou logo o bairro alto desta Cidade, depois de ter causado alguns estragos, para ir-se aninhar na Campina da Ribeira, lugar pouco arejado, ja por causa dos morros de areia, que a circundão, offerecendo barreira á livre circulação dos ventos, e ja por causa do local cerrado e denso, que destrui completamente o doce e suave movimento da viração: lugar em fim onde morão a pobreza, a indigencia, e a miseria, com todos os seus horrores. Portanto é facil de achar-se na má alimentação desses miseraveis, na falta de aceio, e nos excessos de todo genero á que se atirão com furor, a causa porque ahi a bexiga durou tanto, e fizera os maiores estragos: e tanto é assim, que, depois que a Presidencia tomou a providencia acertada de mandar fornecer alimentos e medicamentos á pobreza desvalida, sôb a direcção do Medico do Partido Publico, a peste logo declinou, e a mortalidade logo diminuio consideravelmente pela regularidade do tratamento pharmaceutico dictetico e hygienico". ${ }^{10}$
\end{abstract}

A mensagem de 1851 delimitaria, assim, não só os temas, mas principalmente aqueles espaços por que se bateriam as ações reformistas do discurso civilizador e higienista até o início do século XX. As intervenções de cunho higienista e sanitarista significariam, além do afastamento dos chamados equipamentos insalubres da área urbana e da condenação das águas estagnadas, também disciplinar e domesticar comportamentos e costumes, expurgar tradições que não coadunavam com o "projeto" de cidade moderna ensejado pelas elites - um "projeto" que começaria a ganhar forma apenas com a ascensão da República -, principalmente daquela parte que cada vez mais, com o crescimento demográfico das cidades, seria tematizada como "perigosa", "rude" e "estranha" ao "corpo da cidade", a sua salubridade e moralidade. Discurso que apenas se esboçava aqui, esse disciplinamento e negação são característicos do processo de modernização que ocorreria em grande parte do mundo ocidental. ${ }^{11}$

Sem uma estrutura de "hygiene publica" minimamente organizada - contava-se em Natal apenas com um único depósito de medicamentos e o Médico do Partido Público, cargo existente desde 1831, pelo menos, além dos esporádicos médicos estrangeiros embarcados nos navios que fundeavam o rio Potengi e que acabavam diagnosticando e receitando em terra durante a permanência da sua embarcação ${ }^{12}$ - pouco se podia fazer frente aos imperativos da higiene.

"Esta Cidade tambem se ressente de um mal gravissimo, que fere muito de perto a saude publica, o qual é a falta de Policia Medica, que fiscalise o mercado do peixe, o consumo das carnes verdes, e a venda de todos os generos de primeira necessidade entregue a discrição de quem quer especular, abusando da credulidade de uns, da necessidade de muitos, e do bom senso de todos; mas em fim ainda não; e este o maior dos males: o mais horroroso, por atacar de frente a saude publica, a moral, e a civilisação é haverem ainda expostas à venda em algumas tavernas, onde o pobre

\footnotetext{
${ }^{9}$ Cf. Ventura, 1991, p. 17-68.

${ }^{10}$ Ibidem.

11 A condenação dos costumes tradicionais, a negação de qualquer elemento da cultura popular, a política rigorosa de expulsão dos pobres da área central, além de um cosmopolitismo agressivo e identificado à Paris, conformaram o processo de transformação do espaço, do modo de vida e da mentalidade carioca na virada para o século XX (Cf. Sevcenko, 1983); comentando a "tragédia do desenvolvimento" que pode ser lida no Fausto de Goethe, Berman (1986, p. 68) afirma que o apagar de qualquer vestígio da aparência do velho mundo parece ser endêmico à modernização.

${ }^{12}$ Ferreira et al., 2003, cap.2; Cascudo, 1947, p.203-214.
} 
povo paga caro as embaçadellas, que recebe, substancias medicamentosas, panacéas e, com que especulão aquelles mesmos que ja tem a consciencia calejada no habito de mentir e tudo falsificar?? Cabe aqui informar-vos que, a despeito das diligencias, e esforços que empregou o meu antecessor para levar a effeito a construcção da casa de caridade, decretada pela Lei n.132 de 1 de Novembro de 1845, não lhe foi possivel realisar tão religioso e patriotico empenho, ja pela deficiencia de fundos para isso indispensaveis, e ja por outras causas, que igualmente me tem retardado em lançar os fundamentos de uma obra tão util e necessaria". ${ }^{13}$

As ações de combate às epidemias limitavam-se, até então, às medidas assistenciais organizadas quando as epidemias prorrompiam, com a construção de enfermarias com materiais de rápida execução - estruturas de madeira com cobertura de palha de coqueiro -, distribuição de alimentos e o atendimento médico nas localidades com maior incidência epidêmica, fato que se agravava com o déficit de profissionais da saúde em toda a província do Rio Grande do Norte. Os poucos médicos da região iam e vinham de acordo com a geografia e a virulência das epidemias. ${ }^{14}$ Quadro não muito diferente do restante do país, tendo em vista a situação precária da formação em medicina nas faculdades brasileiras até meados do século $\mathrm{XIX}^{15^{2}}$

Em meio a tal precariedade, o que se afigurava ainda mais urgente era uma solução para as águas e os ares estagnados. Clara ressonância do movimento higienista oitocentista que, sob os influxos da teoria dos meios e da teoria dos miasmas, insistiria sobre "os males advindos da estagnação de todo o tipo - de água, lixo e homens" e faria da circulação um imperativo das reformas das cidades. ${ }^{16}$ Assim, a fonte pública do Baldo e a Campina da Ribeira, elementos naturais estruturais do núcleo urbano do período colonial, presentes nos relatos dos viajantes e na cartografia portuguesa e holandesa desde os primórdios da cidade (fig. 01), são transformados nos dois grandes focos de desequilíbrio da "hygiene publica".

O mapa de Natal de 1864 (fig. 02), presente no "Atlas do Império do Brasil", é o primeiro registro gráfico conhecido em que a cidade deixa de ser indicada apenas como um apenso esquemático aos elementos importantes aos interesses da navegação e defesa territorial da costa brasileira. Além da trama urbana e da massa edilícia representadas, aparece, elemento dominante inconteste na representação bi-dimensional da cidade, a mefítica Campina da Ribeira. Dividindo os dois núcleos iniciais de ocupação da cidade - os bairros da Ribeira e da Cidade Alta -, tornava-lhe mais difícil a comunicação e a circulação, quando da cheia das marés ou com as chuvas, e aumentava o terror miasmático à putrefação, à exalação de vapores e, principalmente, à estagnação das águas e dos ares, tornando-se campo propício, dir-se-ia, para o desenvolvimento e irrupção das epidemias.

\footnotetext{
Outro tanto se póde dizer a respeito da lagoa na Campina da Ribeira, a qual, ficando entre os dous bairros, em que se divide a Cidade recebe as aguas da chuva, como as que jorrão pelo cano do aterro na enchente das grandes marés; dessa mistura fica estagnada uma grande parte que não pode retrogradar, e que se putrefaz, lançando para a atmosféra em abundancia miasmas mortiferos, que felismente, sendo acarretados pelos ventos, que quasi sempre soprão de feição, parte se precipita sobre as águas do rio, e sobre os mangues, e parte vai exercer, reforçando os que lá encontra, sua ação deleteria nos habitantes doutro lado do rio, onde são mui frequentes as febres intermittentes, maxime no inverno [...]". ${ }^{17}$
}

\footnotetext{
13 Wanderley, 1851, p. 13-14; grifos nossos.

14 Cf. Ferreira et al., 2003, cap. 2; Cascudo, 1947, p.203-214.

${ }^{15}$ Cf. Schwarcz, 1993, p. 191-198.

16 Andrade, C., 1992, p.26.

17 Wanderley, 1851, p.13.
} 
O Baldo também demandava preocupações, afinal era a fonte principal para $\mathrm{o}$ abastecimento d'água da cidade:

\begin{abstract}
"Tendo demonstrado quanto é vantajosa a topographia desta Cidade, quanto é bello o ar, a agua pura, e o clima agradavel, devo agora dizer, que a não serem estes beneficios, que a Divina Providencia se apraz de conceder á esta Cidade, a saude de seus habitantes seria flagelada por mil causas de destruição, que o mais grosseiro exame descobre: certamente o Bardo [o Baldo] situado perto de uma das entradas da Cidade (lugar aliás de recreio e distração, e que em outro paiz seria de mil incantos) é um dos focos de infecção; por quanto recebendo no inverno todas as aguas que escoão das eminencias que o dominão, e com ellas as immundicias, que tambem descem; as folhas que se despem as arvores, que o cercão, e que ahi se putrefazem; as impuridades dos vestidos de sãos e doentes, que nelle são lavados; a immundicia sáe com as aguas pelo esgoto, em quanto este tem lugar, mas o resto fica, e fica cada vez peior, não só porque continua a receber impuridades, como tambem porque, crescendo a temperatura, a evaporação se faz com mais força, as aguas se reduzem, seccão, e o lindo Bardo se torna asqueroso e medonho, deixando ver o seu fundo de lodo, e lama putrida, donde se despendem miasmas para asphixiarem o mundo inteiro: entretanto um ou outro caso de febre intermittente perniciosa se observa!"18
\end{abstract}

A partir da mesma preocupação com o desequilíbrio causado pelos "miasmas", o vicepresidente da província registrava ainda os problemas com a localização de alguns equipamentos dentro do núcleo urbano.

\footnotetext{
"Passando dessas causas de insalubridade proprias do terreno ás que nascem da falta de hygiene pública, devo notar o matadouro publico no meio de uma das ruas da Cidade, onde existem constantemente materias animaes em putrefação; de que não resulta o mal que era para temer, por causa da elevação desse terreno, d'onde os ventos atirão para longe os miasmas, que dahi se levantão diariamente; mais a prudencia pede que se remova do centro da cidade esse foco de infecção, o qual pode um dia alterar o ar, e, este assim viciado, produzir os maiores estragos". ${ }^{19}$
}

Embora de forma sucinta, deve-se registrar as diversas ações realizadas para combater a constante insalubridade da capital nos anos seguintes, sempre à mercê dos inúmeros surtos epidêmicos e das levas de migrantes que irrompiam na cidade nos períodos de maior estiagem no sertão, como nas secas de 1877-79, 1890, 1902-04 e 1915. Os equipamentos considerados insalubres foram construídos ou removidos para áreas periféricas, como o cemitério público do Alecrim (1856) - rompendo com a prática das inumações em "solo sagrado", nas igrejas, seus arredores ou em torno dos cruzeiros, que se tornavam impraticáveis com o grande número de óbitos ocasionados pelas epidemias; o "Hospital da Caridade" (1855), o Lazareto da Piedade (1882) e o Mercado Público (1888); em 1882 foi organizado um serviço de abastecimento d'água, com a cessão dos direitos de exploração ao dinamarquês Phelippe Leinhardt; introduziu-se o hábito do banho de mar como prática medicinal, e começou-se a montar um aparato estatal de controle e disciplina social, com legislação e instrumentos repressores próprios, a partir da organização da "Inspectoria de Hygiene Publica" estadual, em 1892. ${ }^{20}$

\footnotetext{
18 Ibidem, p. 12-13.

19 Ibidem, p. 13-14; grifos nossos.

${ }^{20}$ Ferreira et al., 2003, cap.2.
} 


\section{A vaga miseranda passa à porta}

Antes de discutirmos a organização e a tentativa de sistematização das propostas de reforma urbana para Natal nos primeiros anos republicanos, é importante abrir um parêntese para um tema crucial ao processo de modernização das cidades nordestinas na virada para o século XX, embora esteja contemplado apenas transversalmente nesta pesquisa: a temática das secas e, especificamente, a questão dos retirantes nas cidades.

Se o fenômeno climático acompanha a história brasileira desde os seus primórdios, com relatos esparsos já no século XVI e outros mais documentados, com todo o cortejo de horrores que o exacerbou, a partir do século XVIII, seria apenas na seca de 1877-79 que haveria os primeiros esforços para enfrentar o problema: uma comissão imperial foi formada para estudar e propor soluções, principalmente no Ceará. Em Fortaleza, organizaram-se distritos de "abarracamentos" dentro dos limites urbanos, numa tentativa de disciplinamento da multidão de sertanejos que acorreu à capital cearense em um número nunca antes visto mais de 110 mil retirantes numa cidade que tinha ainda pouco mais de vinte e cinco mil habitantes; no Rio Grande do Norte, experimentou-se a criação de colônias agrícolas para conter a massa de retirantes longe da capital.

A falta de estrutura, assistência médico-hospitalar, distribuição de alimentos e, pior, o desvio e malversação dos "socorros públicos", das verbas federais emergenciais destinadas ao combate aos efeitos das secas, ajudam a explicar a tragédia que se seguiu. A colônia Sinimbu, no vale do Ceará-Mirim, hoje dentro da região metropolitana de Natal, com mais de 6.600 pessoas e 1.200 cabanas de palha, tornou-se uma concentração de moléstias, de endemias, resultando no seu fracasso ainda em meio a grande seca. Em Mossoró, Aracati e, em especial, Fortaleza, além das primeiras tentativas de organização com os "abarracamentos", o espetáculo "repugnante" da multidão de miseráveis foi tematizado como uma agressão a "sensibilidade de uma elite urbana civilizada", com as cenas de "anarquia", o aumento desmesurado da criminalidade e da prostituição, as imagens da ociosidade em oposição à ética capitalista do trabalho, a virulência das epidemias (em apenas um dia morreram 1.004 pessoas na capital cearense e nos seus arredores em decorrência da varíola), o aumento extorsivo do preço dos gêneros alimentícios, a corrupção e o desvio das verbas dos socorros públicos, a degradação moral e social que parecia corromper a todos, ricos e pobres e, pior, para as classes dirigentes, o esboço de organização popular, "uma atitude nova, diferente dos padrões rurais de relacionamento com as autoridades, em que a submissão dos camponeses é parte integrante de sua integração social". ${ }^{21}$ O mesmo quadro calamitoso de mortandade e "imoralidade" atingiu Mossoró: entre janeiro de 1878 e outubro de 1879 teriam sido sepultados em seu cemitério público mais de 30 mil pessoas e pelo menos mais de cinco mil nos arredores, onde se organizaram abarracamentos. ${ }^{22}$

Com a contenção da leva de retirantes em 1877 pela colônia Sinimbu, a questão dos retirantes seria colocada de forma dramática em Natal nos momentos mais graves do fenômeno e quando coincidiam com epidemias, como em 1890, 1904, sobremaneira, e 1915. O ainda estudante de Engenharia Henrique de Novaes, ao chegar a cidade em 1904, como integrante da comissão chefiada pelo engenheiro Sampaio Correia para ultimar a estrada de ferro que uniria Natal a Ceará-Mirim, guardaria o relato do seu chefe sobre o estado de convulsão que havia tomado conta da cidade, situação agravada pela epidemia de varíola que se seguiu:

\footnotetext{
${ }^{21}$ Neves, 2000, p.107.

22 A fonte primária sobre as colônias agrícolas criadas durante a seca de 1877-79 é Marconde, 1878, p. 10; a bibliografia sobre as secas é muito extensa e aqui citamos apenas alguns trabalhos: para um esboço histórico da seca no RN Cf. Guerra (1929a) e, no Brasil, Silva (1978, p.90-92) e Avelar Jr. (1994); sobre a seca no Ceará, Cf. Neves (1995; 2000).
} 


\begin{abstract}
"Natal estava invadida por cerca de 4 mil retirantes, a dormirem ao relento nas ruas mais afastadas do centro, quase sem vestes e sem alimentos, que não lhes podia fornecer a pequena população da cidade, em geral pobre, de 10 a 12 mil habitantes no máximo. Vezes várias, as famílias dos engenheiros hospedados no hotel, situado no centro comercial, tiveram de acudir, com um prato de sopa ou com uma fatia de carne, a retirantes, caídos nas proximidades, exaustos de fome". ${ }^{23}$
\end{abstract}

De forma similar ao encantamento e, principalmente, ao terror que a presença das grandes multidões suscitaram nas grandes cidades européias do século XIX, reeditando, em uma escala muito ampliada, a discussão sobre o caráter dual da cidade - "benéfica, segundo uns, efígie do progresso e da beleza, fermento da vida social mesmo no anonimato das multidões; maléfica segundo outros, sinônimo do caos, da perversão, enfim de uma indigência e feiúra" 24 -, a presença dos retirantes nestas cidades marcaria as primeiras representações do perigo social das multidões, das classes pobres, dessa gente "inculta", "rude" e estranha. Alterando a ordem e o encanto civilizatório de espaços urbanos que se transformavam e elitizavam e representados como um estorvo, os retirantes seriam utilizados como justificativa à normatização das esferas pública e privada da vida urbana e às legislações e ações sanitaristas restritivas às práticas populares.

Para fechar este parêntese, é importante observar pelo menos mais dois aspectos relacionados à temática das secas e que dizem respeito diretamente à história urbana e urbanística. Em primeiro lugar, a presença dos retirantes na cidade, além de suscitar e reforçar ações e legislações higienistas que mediavam os interesses das elites em sanear o corpo moral e físico das cidades, justificavam discursos inflamados em prol da região e o pedido de mais verbas federais para os chamados "socorros públicos", recursos que deveriam ser usados, afirmava-se, para minorar os efeitos devastadores da seca na economia.

Mais ainda, a materialização e delimitação da própria região Nordeste surgiu dos discursos sobre as secas e seu quadro de horrores e misérias. Superando a antiga divisão entre Norte e Sul, o Nordeste começou a aparecer como um recorte específico na geografia do país: aquele sujeito às estiagens. $\mathrm{O}$ "Nordeste é, em grande medida, filho das secas; produto imagético-discursivo de toda uma série de imagens e textos, produzidos a respeito deste fenômeno, desde que a grande seca de 1877 veio colocá-la como o problema mais importante desta área". ${ }^{25}$

Assim, não era a imprensa ou os políticos de oposição que denunciavam a calamidade, mas os próprios líderes políticos. Em telegrama para o presidente Rodrigues Alves, Tavares de Lyra, então presidente do Rio Grande do Norte, relatava o quadro de horrores da seca de 1904:

\footnotetext{
"Pelas estradas, misturadas aos bandos de famintos, notam-se já famílias de antiga representação social, que dispunham de relativa fortuna, anniquiladas pela secca. São innumeros os furtos pelos campos, sendo já numerosos os assaltos á casas de comércio e residências. Não resta mais nenhuma esperança de inverno. [...]. Espectaculo da nudez e fome, mesmo na capital, urgentissimo. Nesta cidade, alem do pessoal aproveitado nos trabalhos da estrada do Ceara-Mirim e de milhares que aguardam passagem, [...], vagam pelas ruas outros milhares de indigentes sem abrigo
}

\footnotetext{
${ }_{23}^{3}$ Novaes, 1987, p.69.

${ }^{24}$ Choay, 1996, p.09.

25 Albuquerque Jr., 2001, p. 68; do mesmo modo, Evaldo Cabral aponta que a percepção do nordeste deveu-se decisivamente ao ciclo das grandes secas do final do século XIX e início do XX (Cf. Mello, 1984); é importante ressaltar que a configuração geográfica atual do Nordeste é fruto também de uma série de medidas técnico-políticas, vinculadas principalmente às disputas em torno da abrangência do chamado "polígono das secas", ao longo do século XX; a primeira divisão oficial, que instituiu cinco regiões no Brasil, data de 1938 (na qual o Nordeste era composto pelo Ceará, Rio Grande do Norte, Paraíba, Pernambuco e Alagoas); a composição atual, que acresceu Bahia, Sergipe, Maranhão e Piauí, é de 1969 (Cf. Avelar Jr., 1994, p. 06-10).
} 
nem pão, esmolando da caridade dos habitantes. [...]. Começam a apparecer casos de dysentheria e variola". 26

Talvez nem seja necessário ressaltar que o uso destes "socorros" esteve voltado não para combater seriamente os flagelos das secas, ${ }^{27}$ mas, sim, para resolver os problemas e os arranjos político-eleitorais dos grupos políticos dominantes e, também, para financiar parte das obras de melhoramentos e aformoseamento das cidades. Em Natal, por exemplo, neste mesmo ano de 1904, a Intendência Municipal organizou diversas frentes de trabalho para os retirantes, na abertura de ruas da Cidade Nova, no calçamento e arborização da Cidade Alta, na abertura de picadas e na colocação dos trilhos da estrada de ferro construída sob a direção da comissão da qual Novaes fazia parte, e na construção da praça Augusto Severo, todas realizadas com estas verbas, como bem atestou o governador de então, Tavares de Lyra. ${ }^{28}$ Entre 1915 e 1919, boa parte da construção da estrada de automóveis do Seridó, obra de infra-estrutura essencial para viabilizar e escoar a produção de algodão do estado, foi realizada com a mão-de-obra retirante e com os recursos técnicos da Inspetoria de Obras Contra as Secas (IOCS). ${ }^{29}$

A IOCS, criada por meio do Decreto-lei Federal n. ${ }^{0}$ 7.619, em 21 de outubro de 1909, com o intuito de sistematizar os saberes que se formavam, integrar as ações de combate às secas - conjugando as obras de açudagem, irrigação e circulação ${ }^{30}-$, e centralizar o controle das verbas federais para combater o clientelismo denunciado, acabaria nas mãos dos grupos políticos locais, como ressaltaria o próprio inspetor da IOCS, o engenheiro Aarão Reis, na década de 1910. O seu relatório, de 1920 (quando o órgão já se chamava IFOCS - Inspetoria Federal, mudança instituída por intermédio do decreto n. ${ }^{\circ}$ 13.687, de 9 de julho de 1919), é esclarecedor ao explicitar as razões do malogro das ações do órgão que chefiava: a submissão da técnica aos "interesses de campanário", isto é, às estruturas políticas locais e aos seus interesses eleitorais. Esses interesses determinavam, por exemplo, o traçado das estradas e a localização dos açudes sem obediência às recomendações técnicas, "obras onerosas que bem poderiam ter sido dispensadas, preços quilométricos só explicáveis pela ganância incontida, [...], estações, depósitos, oficinas e mais dependências acanhadas, mal projetadas e mal construídas", além da falta de uma política continuada que garantisse o uso racional dos recursos. $^{31}$

A participação de diversos profissionais, mas sobretudo de engenheiros, na formação e elaboração dos saberes técnicos desenvolvidos acerca do fenômeno das secas ou mesmo na

\footnotetext{
26 Tavares de Lyra (Mens. Gov.), 1904, p.12-13.

27 A crítica à malversação no uso dos "socorros" já estava na pauta de parte da imprensa, como um elemento a mais no jogo político de disputa pelo poder: "A immoralidade tem chegado ao seu auge no que diz respeito a soccorros publicos. [...]. Os dinheiros publicos não servem para matar a fome dos infelizes indigentes, mas sim para encher as algibeiras de meia duzia de felizardos e especuladores politicos. [...] Ao envez disto, porem, a policia espanca os indigentes, as pobres e infelizes mulheres e innocentes creanças; fere-os, levando-os a refe e espada, como succedeu, no bairro da Ribeira, na noite de 22 do corrente! Nem ao menos pagam o salario dos infelizes, que reclamam o que é seu. [...] Com os dinheiros publicos estão se fazendo serviços particulares [...]" (Balzac. "Scenas e factos". Gą̧ta do Natal, Natal, n.128, p.04, 27 jul. 1889).

28 Tavares de Lyra (Mens. Gov.), 1904, p.09: "Contractei com o illustre architecto Herculano Ramos o aterro e ajardinamento da 'Praça Augusto Severo', trabalho indispensável á salubridade desta cidade. Tratando-se do saneamento de um logar, onde desembarcam os retirantes, serviço em que será applicado o material adquerido pela Comissão Central de Socorros [...] entendi que o seu custeio deveria correr por conta dos recursos que dispõe a caixa de origens diversas para auxílio dos flagellados."

${ }^{29}$ Cf. Ferreira Chaves (Mens. Gov.), 1916; 1917; 1918; 1919.

$30 \mathrm{O}$ engenheiro cearense Miguel Arrojado Lisboa, primeiro Inspetor de obras contra as secas, colocava claramente, para o sucesso das ações da agência, a necessidade de conjugar as obras de açudagem e de abertura de estradas com um programa de irrigação, o que seria ratificado por outros profissionais, como Aarão Reis e Clodomiro da Silva; contudo, o terceiro elemento desta tríade que definia a existência da Inspetoria, praticamente nunca foi pauta nas suas ações, não só pela falta de interesse e recursos federais (na década de 1920, criou-se, durante a presidência do paraibano Epitácio Pessoa, uma Caixa Especial para Obras de Irrigação no Nordeste, com receita fixa de 2\% sobre os recursos da União, todavia extinta em 1924 sem mesmo ter sido implantada), mas porque também não interessava aos chefes políticos locais, afinal, programas de irrigação significariam a socialização do uso dos açudes.

${ }^{31}$ Reis, 1920, p.226-249.
} 
administração da IOCS, é o segundo aspecto que interessa destacar. Engenheiros que, como Aarão Reis, tiveram participação direta e decisiva no processo de modernização de várias cidades brasileiras. Além de Reis, responsável pela comissão que trabalhou na elaboração e construção de Belo Horizonte no final do século XIX e Inspetor de obras contra as secas entre 1913 e 1919, os engenheiros André Rebouças, Saturnino de Brito, Adolfo Herbster, Sampaio Correia, Henrique de Novaes e Omar O'Grady, dentre outros, tiveram experiências nestes dois campos de atuação: o combate às secas e o urbanismo, quer na proposição de planos de reforma e expansão ou diretamente na sua administração. Novaes e O'Grady, em especial, porque tiveram uma relação direta com o processo de transformações urbanas de Natal na década de 1920, completaram e forjaram suas formações nas lides da IFOCS, antes de trabalharem como administradores urbanos.

Se as secas eram ou não o principal problema da região, não cabe discutir neste momento; contudo, é importante observar que esses saberes técnicos e científicos que se formaram em torno dos problemas das secas e que pretendiam ultrapassar os limites estreitos do assistencialismo, transformando a natureza da região em um dado quantificável, em uma "fórmula aritmética mais simples", como diria Euclydes da Cunha, na primeira parte d'Os Sertões, ${ }^{32}$ foram transformados numa das peças centrais à constituição da "ideologia do planejamento". Ideologia esta que escudou, sob o véu da "neutralidade" científica, os interesses político-econômicos das classes dominantes locais na disputa pela alocação dos recursos humanos e das verbas federais, ${ }^{33}$ debalde o esforço desses mesmos profissionais em denunciar a submissão da técnica à política.

\section{Cidade Nova para um novo regime}

De forma constante, o "estado sanitário" da capital foi cada vez mais objeto de preocupação nas falas oficiais até a segunda década do século XX. O olhar e o discurso higienista se tornaria recorrente, apontando, em especial e cada vez mais, a necessidade de pôr termo aos hábitos desregrados da maioria da população. Pedro Velho, ${ }^{34}$ por exemplo, Inspetor de Saúde Pública do governo provincial em 1886, atribuiria quase que exclusivamente à "incúria da população" as causas para o estado "pouco lisonjeiro" da higiene pública de Natal:

\footnotetext{
"A cidade do Natal, principalmente a parte denominada Cidade Alta ocupa uma situação topográfica altamente vantajosa, no ponto de vista da higiene. Constante e largamente lavada pelas vivificantes correntes do ar marítimo, sem focos naturais de infecção, dispondo hoje do grande melhoramento de ter água canalizada, em chafarizes e nas casas particulares, o que lhe falta depende, como dissemos, da incúria da população, e pode reduzir-se a dois pontos capitais: - melhor alimentação e mais asseio. [...]. No que diz respeito a asseio podemos afirmar que não há nenhum, como provam imundas esterqueiras, em ruas e travessas de trânsito público, onde, aos raios ardentes do sol de estio, entram em rápida decomposição, viciando a atmosfera e exalando um cheiro insuportável, detritos vegetais de toda natureza". ${ }^{35}$
}

\footnotetext{
32 Cunha, 1902, p.34; a propósito, Euclydes da Cunha foi engenheiro civil e militar, formado pela Politécnica do Rio de Janeiro e pela Escola Militar, respectivamente, e trabalhou na superintendência de obras públicas da prefeitura de São Paulo e alguns meses na comissão de saneamento de Santos, em 1904.

33 Cf. Silva, 1978.

34 Pedro Velho de Albuquerque Maranhão, médico formado pela Faculdade de Medicina do Rio de Janeiro em 1881 (embora tenha estudado os quatro primeiros anos na Faculdade da Bahia), e jornalista, foi um dos principais agitadores e articuladores republicanos no Rio Grande do Norte, um dos fundadores do jornal A República, governador do estado entre 1892 e 1896, deputado federal e senador até 1907, ano do seu falecimento, e principal líder político da chamada "oligarquia Albuquerque Maranhão"; o poder político do seu grupo familiar à frente do governo estadual perduraria de 1892 até 1913 (Cf. Oliveira, 1999, e Souza, 1989).

35 Apud Cascudo, 1947, p.210-211.
} 
Para combater esta "incúria" e os focos não naturais de infecção começaria a ser montado um aparato médico-sanitarista restritivo e punitivo, que tentaria cada vez mais avançar, por meio de procedimentos amparados numa legislação higienista, nas esferas da vida na cidade, quer públicas ou privadas, o que mostra a ampliação da própria noção de higiene e saúde públicas.

Se é verdade que os dicionários não dão conta da velocidade das mudanças semânticas, eles de alguma maneira cristalizam e demarcam os significados e acepções das palavras de um determinado período. Neste sentido, e apenas para ilustrar, vale lembrar os verbetes sobre saúde e higiene de dois destes que pertenceram a intelectuais locais e hoje compõem o acervo do IHGRN. Para Francisco Constancio, no segundo quartel do século XIX, a higiene era um ramo da medicina que ensinava a conservar a saúde; esta, por sua vez, seria o estado de "perfeita conservação das funcções dos homens e dos animaes". No início do século XX, o dicionário de Castelbranco já abrange o adjetivo "pública" à noção de higiene, referindo-se ao "conjunto de conhecimentos e preceitos que asseguram a saude das populações consideradas em massa"; a saúde referia-se ao perfeito equilíbrio das funções orgânicas do indivíduo, a não existência de doenças, ao vigor e à conservação das forças físicas. $^{36}$

A ampliação dessas noções é sem dúvida tributária dos esforços de constituição da medicina como ciência social ao longo do século XIX, para a qual os cuidados com a saúde eram de "natureza essencialmente social"; ademais, como afirmariam os médicos alemães, por exemplo, era essencial entender o mundo moral e físico em que o indivíduo estava inserido para diagnosticar as doenças e combatê-las com precisão. ${ }^{37}$ Esforços que teriam clara ressonância no corpus teórico dos principais centros difusores da profissão no Brasil, principalmente no período pós-1870: as faculdades de medicina do Rio de Janeiro e de Salvador. ${ }^{38}$

Logo no início do governo de Pedro Velho (1892-1896) seria criada a "Inspectoria de Hygiene Publica", cujas atribuições incluíam a "fiscalização do saneamento das localidades e das habitações" e "a inspeção de escolas, repartições públicas, fábricas, estabelecimentos de empresas, oficinas, hospitais, lazaretos, hospícios, prisões, quartéis, estabelecimentos de caridade e beneficência, arsenais, asilos e quaisquer habitações coletivas, públicas ou particulares". ${ }^{39}$ Nos anos seguintes seriam acrescidas à legislação sanitarista as atribuições e a abrangência da ação do inspetor de higiene, do médico ajudante, dos delegados sanitários e demais funcionários, as multas e punições às infrações ao código sanitário e o serviço da polícia sanitária, proposições e ações que começariam a mudar um espaço urbano indistinto socialmente, onde ricos e pobres conviviam contiguamente.

Não se pode deixar de mencionar que essa série de normativas, restrições e punições, escudadas no combate à cidade insalubre, guarda uma relação direta com a formação dos territórios populares na cidade, expulsando os moradores que não tinham condições de obedecer às novas exigências construtivas para os dois bairros centrais - a Cidade Alta e a Ribeira - e contendo a grande leva de retirantes que acorria à cidade fugindo das secas e em busca de trabalho nas obras de modernização da capital, na construção de ferrovias, nos melhoramentos do porto (figura 03), na abertura de estradas, ruas e avenidas. ${ }^{40} \mathrm{O}$ surgimento de bairros como o Alecrim, as Rocas e o Passo da Pátria, por exemplo, está vinculado aos movimentos dessa nova lógica de ocupação espacial, na qual a segregação se tornaria estrutural.

\footnotetext{
36 Constancio, 1836; Castelbranco, 1918.

${ }^{37}$ Cf. Rosen, 1980, p.77-141 passim.

${ }^{38}$ Cf. Herschmann, 1994; Schwarcz, 1993.

39 Anexo da Inspetoria de Higiene (assinado pelo Dr. Segundo Wanderley) In Chaves, 1896, p.02.

${ }^{40}$ Cf. Santos, 1998; Oliveira, 1999.
} 
Se as mensagens oficiais e os eufemismos em torno da insalubridade da capital iam e vinham junto com as epidemias, o que não deixa de revelar a falta de qualquer ação efetiva, é certo que o tema da cidade insalubre logo seria consubstanciado nos discursos sobre a necessidade da modernização econômica de Natal; seria o fio principal a compor a tessitura de uma trama que reclamaria de forma veemente transformações e reformas urbanas. Com o advento da República, as capitais e cidades mais avançadas econômica e politicamente ganharam um novo status dentro do processo conturbado de passagem de uma sociedade agrária para uma urbana no Brasil. A cidade não seria apenas o locus de uma nova civilidade forjada à européia, mas, no contexto latino-americano, um elemento central para "criar a modernidade, estendê-la e reproduzi-la". ${ }^{11}$

Isso se traduziria inicialmente, em Natal, nas discussões em torno da superação do isolamento geográfico da cidade - confinada, como enfatizariam muitos, entre as dunas, o rio e o mar -, cujas conseqüências não se mediam apenas nos parcos indicadores econômicos, mas, principalmente, nos vários aspectos de sua vida social. ${ }^{42}$ Para além das mensagens oficiais ou dos relatórios técnicos, foi principalmente nas páginas dos periódicos que os apelos, as reclamações, as repreensões, as demandas pelo "progresso", enfim, ganharam forma e cores mais vivas.

A imprensa, como um veículo de expressão dos poucos setores mais articulados da sociedade, assumiu o papel de "ponta de lança" da modernidade. Foi onde os intelectuais encontraram espaço para externar a necessidade de modernizar o país, suas estruturas e seu povo, atualizando-o frente ao mundo civilizado. Como aríetes a solapar antigos hábitos e tradições, atribuindo valores, julgando e apontando o certo e o errado, consideravam-se não apenas representantes dos novos tempos, mas condição precípua para a sua concretização. ${ }^{43}$

Assim, em Natal, ao lado das demandas pelos melhoramentos do porto, pela constante dragagem do leito do rio e pela desobstrução da sua barra de entrada, eram noticiadas constantemente aquelas que implicavam a normatização do espaço urbano da cidade. O serviço de correios, por exemplo, não poderia continuar funcionando baseado apenas nos topônimos locais de uso tradicional:

\footnotetext{
“... uma falta muito sensivel é notada ahi, principalmente pelas pessoas que têem correspondencia para a cidade do Natal. Refiro-me á ausencia de placas de denominação das ruas e praças, e numeração das casas. Como a cidade é pequena e todos [...] se conhecem, a camara municipal entende que o serviço do correio pode ser feito muito bem. A verdade é que, quando chega ahi uma pessoa sem posição saliente e a quem se escreve de fóra, as cartas ficam retidas porque aquelles que as escrevem não podem bem endereçal-as [...]. Algum estranho que ahi chega e que procura saber a casa de um amigo ou parente não se lhe pode fazer mais do que ensinar-lhe com os classicos: vá por aqui, dobre a mão direita, desça acolá, e, ou então fazel-o proceder de uma pessoa que o conduza pelo labyrintho de nossas ruas". ${ }^{4}$
}

Não havia mais espaço para denominações como rua estrada nova, rua da palha, beco novo, rua capoeira, rua atrás da cadeia, rua da luz onde mora Pereira, descida do Rosário ou mesmo a rua Grande, largo em torno da qual se dispuseram as primeiras casas e prédios públicos da cidade, o poder religioso e o secular. Agora seriam, respectivamente, ruas José de Alencar, 21 de Março, Voluntários da Pátria, Gonçalves Dias, 11 de Junho, Felipe Camarão,

\footnotetext{
${ }^{41}$ Gorelik, 1999, p.55-56.

42 Como será discutido no cap. II, o tema do isolamento geográfico e econômico é essencial para o "projeto" historiográfico local que começou a se estruturar com o advento da República.

43 Sobre o papel dos intelectuais na primeira República, Cf. Sevcenko, 1983; sobre o da imprensa, Cf. Goodwin, 2000; Bertucci, 1996.

${ }^{44}$ S/t, Gazeta do Natal, Natal, n.27, p.04, 31 mar. 1888; grifos nossos.
} 
Sete de Setembro e Praça André de Albuquerque..$^{45} \mathrm{O}$ enquadramento do espaço urbano, numerando-o e nomeando-o, aqui preocupado com a assunção de símbolos pátrios e de identificação republicana, levava ao estranhamento da população, colocada à mercê deste projeto de modernização e que via os seus valores e signos de reconhecimento não se ajustarem aos novos padrões de civilidade. De fato, a institucionalização das denominações destrói os registros populares, "desfazendo os suportes subjetivos da memória da população local e da identidade coletiva de um determinado território urbano". ${ }^{46}$

Mesmo assim, o registro antigo ainda teimou em persistir ao lado da nomenclatura oficial. Como lembraria Câmara Cascudo várias décadas depois, em seu livro de memórias: "Nasci [em 1898] na rua José Bonifácio, que ninguém sabia em Natal quem fora. Toda a gente a dizia Rua das Virgens, no bairro da Ribeira". ${ }^{47}$

Longe de ser um apenas episódio anedótico ou pitoresco do processo de modernização, as propostas de regularização da nomenclatura das ruas revelam muito das características do "projeto" de reforma urbana que as elites propugnavam e que, em Natal, apenas esboçavam no final do século XIX. Além do interesse em modernizar o sistema administrativo urbano, o que está intimamente relacionado ao sistema policial e fiscal, essas propostas, ao fazer uso de temas e nomes nacionais, demonstram também o esforço em superar o caráter provinciano e acanhado da cidade. ${ }^{48}$ Não à toa, no final da década de 1920 , o IHGRN proporia uma nova regularização da nomenclatura das ruas, praças e largos de Natal, justificando-a como complemento necessário ao Plano Geral de Sistematização. ${ }^{49}$

Do mesmo modo, as práticas herdadas do mundo rural - como os tiros de roqueira a qualquer hora do dia ou da noite - e aquelas que eram consideradas um estorvo à moralidade urbana civilizada, enfim, as práticas populares como um todo, também não coadunavam com este projeto de civilidade que cada vez mais se afirmava, não somente em Natal, mas em todo o Brasil. A Ribeira, bairro comercial e "porta de entrada" para os visitantes e passageiros em trânsito, não podia mais ter "vivandeiras" nem "cortiços" dando

\footnotetext{
“à sociedade espectaculos de quadros vivos à portas abertas! Ahi ellas praticam as maiores immoralidades, proferem em vozes altas palavras tão cabelludas que arrepiam as carnes, [...], e quando dão para gritar, saltam, berram, como se estivessem em hospital de doudos.

Taes e tão immoraes scenas as farçantes representam com os ganhadores de rua, e os carregadores de canecos d'agua, que, [...], rolam pombos à vista de todos!

A moral publica offendida, a sociedade insultada e as familias desrespeitadas, pedem e imploram a vós, cidadão dr. Chefe de Policia [...]". ${ }^{50}$
}

Estes costumes e práticas "brutais e inconvenientes" de um "povo rustico e ignorante" 51 não podiam mais fazer parte do espaço urbano de uma cidade que pretendiam civilizar. Sob o enquadramento de "usos indevidos", as representações da rafaméia, das chamadas classes perigosas, foram lidas a partir da interpretação local dos padrões estrangeiros de civilidade e moralidade, notadamente europeus, afastando-os dos centros e das áreas que às

\footnotetext{
45 Proposta, depois efetivada, da Câmara municipal de Natal publicada na Gaz̧eta do Natal, Natal, n.40, p.03, 16 maio 1888.

46 Bresciani, 2001, p.13.

47 Cascudo, 1968, p.39; Ramón J. (2001, p.133), discutindo o projeto de 1860 de regularização da nomenclatura da cidade de Lima, no Peru, afirma que, mesmo depois de 25 anos de realização das mudanças, a população local continuava a usar as antigas e tradicionais denominações.

48 Ramón J., op. cit.

49 A proposta alterava a nomenclatura de 169 logradouros púbicos, relacionando-os às efemérides da história do Rio Grande do Norte; Cf. "Sugestões do IHGRN para as novas designações e suas justificativas das ruas de Natal", A República, Natal, n. 162 , p.04, 16 jul. 1930.

50 (assinam “diversas famílias”). "Cidadão, Dr. Chefe de Policia”, Gazeta do Natal, Natal, n.154, p.04, 08 fev. 1890.

51 (assina "uma victima”). "Os tiros de roqueiras", Gazeta do Natal, Natal, n.170, p.04, 07 jun. 1890.
} 
elites interessavam ordenar. ${ }^{52}$ Que as "vivandeiras" fossem para detrás do quartel ou para a rua do Camboim, ${ }^{53}$ isto é, para a não-cidade, descampados não normatizados afastados dos estreitos limites urbanos de então.

Quando o inspetor de higiene em 1896, o médico Segundo Wanderley, ${ }^{54}$ propôs o arrasamento da fonte pública do Baldo, não o fez apenas porque era considerado um "foco perene de molestias miasmaticas", mas porque se convertia "diariamente em theatro de escandalosas exibições, affectando não só a integridade sanitaria, como attentando affrontosamente contra os bons costumes e moralidade publica" ${ }^{55}$ Consolidava-se um novo padrão moral que não aceitava ou incluía as práticas, tradições e costumes populares (e o saber da medicina popular, por exemplo, com seus elixires, chás, etc.), lidos como desregrados, ignorantes, promíscuos, fruto de uma gente nascida de uma "mistura perversa de raças e tradições", sem aptidão para a disciplina do trabalho, cultivados no ócio e na indolência, num apego às crendices passadistas resistentes às luzes da Razão. ${ }^{56}$ Tal era a imagem do povo brasileiro construída por diversos intelectuais, juristas, médicos, cronistas, de um pensamento cientificista que veria nas reformas urbanas e no fomento à imigração estrangeira a possibilidade de regeneração racial e social desta população, ou de parte dela, afinal os negros, mulatos, mamelucos eram considerados antropologicamente inferiores, quando não congenitamente incapazes para o trabalho livre. ${ }^{57}$

A proposta do médico Segundo Wanderley traduz esse momento em que o ímpeto do "projeto" civilizador e modernizador do país formulava-se indissociável das reformas urbanas. "Difficil e muito difficil se torna o saneamento de uma Capital nas condições que a nossa se acha collocada, ressentido-se da falta de um calçamento regular, sem um systema de esgôto apropriado, cuja maioria dos quintaes è feita de fachina e as cloacas abertas na superficie do solo", afirmaria o médico. Para acautelar a "saude publica", continuou, fazia-se urgente mais três "melhoramentos de carater sanitario", além do arrasamento da fonte do Baldo e da série de medidas profiláticas: o aumento do aqueduto que desviava as águas pluviais que se acumulavam na Campina da Ribeira; a remoção do matadouro público; e a mudança do lazareto ou a construção de um novo prédio fora do perímetro da cidade, de tal forma situado que não levasse as suas emanações para a cidade. ${ }^{58}$

Apesar dos esforços da Inspetoria de Higiene ou mesmo, embora em menor medida, da Intendência Municipal, ${ }^{59}$ o alcance dessas propostas permanecia reduzido não apenas devido ao restrito orçamento de um estado e de um município de recursos exíguos, mas também às próprias limitações de um saber especializado que ainda se construía. Se o campo urbanístico nem mesmo se nomeava, o médico sofria as conseqüências da chamada "revolução bacteriológica", que mudaria decisivamente a forma como se explicava a propagação das doenças.

A criação da Cidade Nova (atuais bairros de Tirol e Petrópolis), o terceiro bairro oficial de Natal, um sistema reticulado de baixa densidade e de amplas avenidas (fig. 04), incorporou uma série de temas presentes no debate higienista, como a exigência legal dos recuos entre as habitações, que implicaram em mudanças na forma urbana e na tipologia da cidade. Iniciada em 1901, segundo a resolução municipal n. 55, e “concluída” em 1904 pelo agrimensor italiano Antonio Polidrelli, funcionário da Intendência de Natal, configurou-se

\footnotetext{
${ }^{52}$ Cf. Ribeiro e Cardoso, 1996; Pechman, 1996.

${ }^{53} \mathrm{~S} / \mathrm{t}$, Gazeta do Natal, Natal, n.154, p.04, 08 fev. 1890.

${ }^{54}$ Médico formado pela Faculdade de Medicina da Bahia, em 1886, Manuel Segundo Wanderley (1860-1909) participou também da vida política e cultural da cidade: abolicionista, republicano, mas também poeta, jornalista e teatrólogo (Oliveira, G., 1999, p.116).

55 Anexo da Inspetoria de Higiene In Chaves, 1896, p.02.

56 Telles, 1999.

${ }^{57}$ Rolnik, 1997, p.67-74

58 Anexo da Inspetoria de Higiene In Chaves, 1896, p.02.

${ }^{59}$ Um breve apanhado sobre a atuação da Intendência Municipal será discutido no capítulo IV.
} 
como a negação radical da cidade antiga, colonial, cujos hábitos, edifícios e equipamentos eram considerados insalubres.

As choupanas e casebres pobres existentes foram desapropriados ou vendidos, por pouca coisa, quase nada, em terras que ainda pouco valiam. Há registros de que pelo menos 300 moradias tenham sido colocadas abaixo para a abertura das avenidas projetadas. ${ }^{60}$ Logo tornar-se-ia destino obrigatório e preferido da elite local: primeiro para fins de semana esporádicos e depois, ao longo das décadas, como moradia fixa para as classes mais abastadas. Inspirado em Pedro Velho, o governador de então Alberto Maranhão (1900-1903 e 19081913) ${ }^{61}$ recordaria, em carta endereçada a Câmara Cascudo, as razões da Cidade Nova: a imperial Petrópolis fluminense denominou o antigo Belmonte, o Tirol "foi uma simples fantasia sem justificação real. Uma lembrança da província austríaca, qualquer coisa de reminiscência recalcada de leituras literárias, e nada mais". ${ }^{62}$

Se a posterior escolha dos nomes para a Cidade Nova não passava de mera reminiscência literária, ${ }^{63}$ o que não deixa de revelar o olhar desterrado das elites para a sua própria cidade, a sua criação teve influência decisiva na estruturação futura de Natal. O bairro seria o espaço por excelência do novo regime na cidade, ${ }^{64}$ tanto pela conformação de uma estrutura urbana que não se articulava com a parte antiga da cidade, herdada do período colonial, quanto pelo aspecto exclusivo que marcou a consolidação de um processo de crescimento que tinha na segregação sócio-espacial um elemento estrutural.

A Cidade Nova foi a síntese desta imagem da cidade salubre criada pela elite: higiênica, ampla, larga, cujo reticulado orientava-se pela penetração dos ventos dominantes, mas também expurgada das choças e casebres, da gente pobre que habitava o futuro bairro, da incúria que ajudava a disseminar epidemias. Muito além dos estros literários, dos sítios e pontes bucólicas, a constituição da Cidade Nova lançou as bases para implantação de um mercado de terras, expropriando ou expulsando posseiros e valorizando os terrenos de políticos, comerciantes e pequenos industriais vinculados ao grupo político local, principalmente com a criação e expansão das linhas de bonde à tração animal, em 1908, e elétrico, em 1911. ${ }^{65}$

Além da Cidade Nova, uma série de propostas, resoluções e medidas se sucederam até 1913, conformando o primeiro ciclo de reformas urbanas por que Natal passou, a sua Belle Époque. ${ }^{66} \mathrm{~A}$ introdução de inovações técnicas, de novos serviços e equipamentos urbanos, mas principalmente a ênfase no melhoramento e "aformoseamento" do espaço urbano da cidade, com a construção de praças, largos, avenidas e alguns edifícios "modernos" - ecléticos ou neoclássicos -, foram decisivos para espraiar o sentimento de se estar vivendo em uma cidade em transformação, nova, moderna. Alguns cronistas mais entusiasmados saudavam como fato consolidado os novos hábitos, os maneirismos e as roupas, de preferência talhadas na "dernier

\footnotetext{
60 Sobre a Cidade Nova, Cf. Cascudo, 1947; Miranda, 1981; Ferreira, 1996; Santos, 1998; Oliveira, G., 1999; Ferreira et al., 2003.

${ }^{61}$ Alberto Frederico de Albuquerque Maranhão nasceu em Macaíba-RN, em 1872, e faleceu em Angra dos Reis-RJ, em 1944; formou-se bacharel em Direito pela Faculdade de Pernambuco, a exemplo de quase todos os representantes da elite política e intelectual local, foi promotor público de Macaíba, secretário de estado entre 1892 e 1895, procurador geral do estado até 1900, quando assumiu o seu primeiro mandato como governador; foi ainda diretor do jornal A República e deputado federal, entre 1904 e 1908 (Cf. Oliveira, G., 1999, p.112-113).

62 Alberto Maranhão (em carta da década de 1930 ou 40) apud Cascudo, 1947, p. 351-357.

${ }^{63} \mathrm{Ou}$ talvez e muito provavelmente reminiscência dos anos de estadia na capital federal como deputados ou senadores que assistiam ou acompanhavam o corpo diplomático evadir-se em massa à Petrópolis fluminense nos meses de calor, quando aumentavam a ocorrência das epidemias e endemias (Cf. Carvalho, J., 1987, p.19).

${ }^{64}$ Santos, 1998, p.42-54, 207.

${ }^{65}$ Cf. Ferreira, 1996; Santos, 1998.

66 Sobre as reformas urbanas empreendidas nesse período, Cf. Souza, I., 1989; Santos, 1998; Ferreira et al., 2003, e, em especial, Oliveira, G., 1999, que discute os vínculos entre as propostas e ações de transformação do espaço físico da cidade e o projeto político-econômico do grupo político dos Albuquerque e Maranhão, que, baseado economicamente nos engenhos de açúcar e na indústria salineira, governou e dominou o estado entre 1892 e 1913, e cujo principal líder e articulador foi o médico Pedro Velho.
} 
cri de la mode parisien", exigidos para os (poucos) espaços transformados em cenário da vida urbana: "Domingo passado, o povo elegante de Natal, affluiu extraordinariamente ao jardim da praça Andre de Albuquerque. Ali vimos, o que havia de melhor na nossa sociedade: d'este rapaz smart e maneiroso á mademoseille garrola e encantadora. Foi portanto aquella, a reunião chic da fleur fine do nosso meio social". ${ }^{67}$

Entusiasmo derivado, sem dúvida, da série de ações que tiveram impacto, direto ou indireto, nas possibilidades de transformação e de usufruto desse espaço urbano. Dentre essas, o início das obras do Teatro Carlos Gomes (atual Alberto Maranhão), em 1898; a complementação da linha férrea entre o Rio Grande do Norte e a Paraíba, em 1902; a publicação da extensa Resolução n. ${ }^{\circ}$ 92, em 1904 - que, entre as várias normativas que buscavam regular as esferas da vida pública e privada em Natal, dedicou um capítulo específico ao tema da habitação, tornando obrigatório alinhamentos, dimensões mínimas para fachadas, janelas, portas, calçadas e, apenas para a Cidade Nova, recuos lateral e frontal; a contratação, nesse mesmo ano, do arquiteto Herculano Ramos ${ }^{68}$ para conclusão das obras do teatro, além da sua decoração e cenografia, e para projetar, desenhar e conduzir a construção da Praça Augusto Severo (figs. 05 e 06) - construída em frente ao teatro, sobre a antiga e "miasmática" Campina da Ribeira, tornar-se-ia um dos símbolos principais desse primeiro ciclo de reformas urbanas, um espaço elegante, salubre e civilizado, em uma cidade tematizada como infecta e incivil, local para olhar e ser visto, para a realização do footing, antes e depois das apresentações teatrais; entre 1904 e 1908, foram concluídas as obras de construção da ferrovia Natal-Ceará-Mirim; o saneamento da fonte do Baldo, transformada em logradouro público aberto à população; a reforma do bairro comercial da Ribeira, com a retificação de algumas ruas, como a do Commercio, a abertura de novas, como a Sachet (atual Duque de Caxias), a Almino Afonso e a Tavares de Lyra, e o aterro e nivelamento da Praça Leão XII; o "aformoseamento" da Cidade Alta, com o calçamento e arborização de suas principais ruas e a demolição de dezenas de edifícios que não atendiam às exigências de alinhamento e salubridade; e a continuidade das obras de desmatamento e abertura das ruas projetadas para a Cidade Nova. ${ }^{69}$

A segunda administração estadual de Alberto Maranhão (1908-1913) marca o ápice e, ao mesmo tempo, o fim desse primeiro ciclo de reformas urbanas. Período no qual a cidade ou melhor, algumas de suas avenidas, largos e praças - foi pensada como o suporte físico e simbólico do poder de sua elite; no qual, formulava-se, a cidade teria superado o atraso da sua estrutura colonial e a insignificância na rede urbana estadual e regional e tornado-se uma capital de fato, centro administrativo, político e econômico do Rio Grande do Norte.

Ápice porque ocorreu uma aceleração nos esforços de modernização e, em especial, a introdução de inovações técnicas que tornaram mais visível e plausível o sentido de progresso e de moderno, como o bonde e a eletricidade. Ainda em 1905, quando a Empresa de Iluminação a Gás Acetileno foi inaugurada e substituiu os antigos lampiões a querosene, usava-se apagar os bicos de luz três dias antes e até três dias depois do período de lua cheia. ${ }^{70}$ Apesar dos problemas na produção e distribuição da energia elétrica em Natal a partir de 1911, quando foi construída a Usina Elétrica do Oitizeiro, a eletricidade suscitou a ampliação das possibilidades e dos significados da vida urbana: uma vida social noturna mais freqüente, a ida aos cinemas, a importação e uso de eletrodomésticos, a música nas vitrolas, as bombas de

\footnotetext{
67 "Cronica mundana”, Gazeta da Semana, Natal, n.1, p.02, 23 ago. 1914.

${ }^{68}$ Nascido em Minas Gerais, cursou a antiga Academia Imperial de Belas Artes no Rio de Janeiro e complementou seus estudos de construção civil na Europa. Fez parte de diversas comissões no Brasil a partir de 1876, como naquela que avaliou a Casa de Detenção do Recife, em 1882 (Segawa, 1998, p.30). Contratado em 1904, permaneceu em Natal até 1914, pode-se dizer que foi o responsável pela feição arquitetônica e paisagística do primeiro ciclo de reformas urbanas em Natal (Cf. Maranhão, 1904; Tavares de Lyra, 1904, 1905; Miranda, 1981; Oliveira, G., 1999).

${ }^{69}$ A lista de obras e serviços citados nesse parágrafo baseou-se nas mensagens de governo (de 1898 a 1914) e em Oliveira, G., 1999, p.59-95.

${ }^{70}$ Cascudo, 1947, p.301.
} 
distribuição para o abastecimento d'água. Sabe-se que, mesmo mal aproveitada, vinculada ao capital estrangeiro e sem pesquisa nacional que incentivasse a expansão do consumo para a maioria da população durante a Primeira República, a eletricidade foi "motor" essencial à modernização, à industrialização das regiões mais avançadas economicamente do país. ${ }^{71}$

Contudo, sem estrutura administrativa e recursos financeiros suficientes, tanto na esfera de governo estadual quanto municipal, para executar os serviços e obras idealizados, o governo de Alberto Maranhão valeu-se de duas medidas básicas. Primeiro, contratou - ou mesmo incentivou a criação de - diversas empresas que os realizassem, como a empresa para os melhoramentos do porto, a Companhia Ferro Carril de Natal, criada em 1908, para transporte, com bondes à tração animal, de cargas e passageiros dentro do perímetro urbano da cidade, e a Empresa de Melhoramentos de Natal, a qual foi entregue a maioria dos serviços urbanos anteriormente a cargo do Estado (a gerência da concessão de aforamentos, do abastecimento d'água, a construção da usina elétrica, em 1911, e, em conseqüência, a organização do sistema de iluminação e do bonde elétricos).

\begin{tabular}{|c|c|c|c|}
\hline \multicolumn{2}{|c|}{ Quadro 01: Investimentos (do governo estadual) em Natal } & \multirow{2}{*}{\multicolumn{2}{|c|}{1911}} \\
\hline \multicolumn{2}{|c|}{1910} & & \\
\hline Item & Valor (em Contos de Reis) & \multicolumn{2}{|r|}{ Valor (em Contos de Reis) } \\
\hline Calçamento & $19: 795 \$ 013$ & Calçamento & $95: 605 \$ 013$ \\
\hline Hospital Juvino Barreto & $3: 290 \$ 830$ & Jardins e praças públicas & $36: 708 \$ 588$ \\
\hline Penitenciária & 33:000\$ & Arborização & $1: 207 \$$ \\
\hline Arborização & $1: 207 \$$ & Teatro Carlos Gomes & $149: 400 \$ 680$ \\
\hline Teatro Carlos Gomes & $30: 694 \$ 650$ & Avenida Tavares de Lyra & $38: 325 \$ 930$ \\
\hline Parque Estadual & $780 \$ 040$ & Avenidas na Cidade Nova & $28: 993 \$ 272$ \\
\hline Polígono de tiro Deodoro & $4: 217 \$ 880$ & Avenida Junqueira Ayres & $4: 300 \$$ \\
\hline Avenida Tavares de Lyra & $18: 263 \$ 350$ & Inspetoria de Higiene & $9: 300 \$ 023$ \\
\hline Asilo Padre João Maria & $540 \$$ & & \\
\hline Palácio do Governo & $743 \$ 300$ & & \\
\hline Avenidas 9 e 10 na Cidade & $2: 044 \$ 340$ & & \\
\hline \multicolumn{4}{|l|}{ Nova } \\
\hline Atheneu & $1: 230 \$$ & & \\
\hline Armazém do almoxarifado & $15: 060 \$ 620$ & & \\
\hline Quartel de Segurança & $9: 136 \$ 192$ & & \\
\hline Estação do Porto do Padre & $7: 212 \$ 050$ & & \\
\hline Armazém para Inflamáveis & $19: 618 \$ 625$ & & \\
\hline Inspetoria de Higiene & $102 \$ 500$ & & \\
\hline Para um total de & $166: 936 \$ 390$ & Para um total de & $877: 908 \$ 795$ \\
\hline
\end{tabular}

Em segundo lugar, a captação de recursos externos vultosos que possibilitassem, justificava-se, a aceleração do processo de modernização, o "aformoseamento" da capital e o desenvolvimento das forças produtivas do estado. Em 18 de setembro de 1909, o governador sancionou a lei n. 270, autorizando o empréstimo de cinco mil contos de réis $(5.000: 000 \$)^{72}$ junto a bancos franceses, valor então correspondente à arrecadação de quatro anos do estado. A lista de "obras públicas na capital" entre 1910 e 1911 é muito extensa e, dela, cabe destacar o montante de recursos destinados aqueles espaços e obras que pretendiam suscitar e forjar

\footnotetext{
71 Magalhães, 2000.

72 Ou o equivalente a 350.000 Libras, com os banqueiros Perles Frêres, Engene Vasseur e o Banco Sindical Francez, que seriam "amortizaveis em 37 annos, á razão de $1 \frac{1}{2} \%$ por semestre e a juros de $5 \%$ ao anno. Foi representado do estado no extrangeiro para tal fim o Sr. Hidelfonso Pereira Simões, agente de negocios estabelecido na praça do Recife. O estado deu como garantia especial a renda sobre o imposto da exportação do sal e os rendimentos extraordinarios provenientes dos serviços a se effectuarem com os fundos do dito emprestimo" (Maranhão, 1910, p.34). A transcrição do contrato original, em francês, é encontrado na mensagem de governo de 1927 (Cf. Medeiros, 1927, p.190-197). O empréstimo só terminaria de ser pago em 1954 (Souza, I., 1989, p.237).
} 
novas sociabilidades dentro de um padrão de civilidade burguesa. O Teatro Carlos Gomes (fig. 07), por exemplo, cuja reforma, elaborada e executada sob a direção do arquiteto Herculano Ramos, consumiu mais de $17 \%$ do total dos investimentos em obras públicas realizadas em Natal nestes dois anos. ${ }^{73}$

Por outro lado, esse momento significou também o fim desse primeiro ciclo de reformas urbanas e o início de uma "crise" urbana - uma série de representações que procuraram tematizar os significados da perda e da não continuidade do processo de modernização - que perduraria até o início da década de 1920, o que se explica, mas não se esgota, pela história política e econômica local.

Várias razões podem ser evocadas para explicar este processo. Desde a perda de coesão e capacidade de articulação política da "oligarquia" dos Albuquerque e Maranhão após mais de duas décadas à frente do poder estadual, principalmente depois do falecimento do seu principal líder, o médico Pedro Velho; pelo declínio do principal sustentáculo econômico desse grupo político: a indústria canavieira; ${ }^{74}$ ou pela própria fragilidade econômica do estado, incapaz de suportar a sobrecarga no orçamento causada pelo pagamento dos juros e pela amortização do empréstimo francês de 1909; pelo início da Primeira Guerra Mundial, que causou a desvalorização de diversos produtos exportados pelo porto de Natal, e pela grande seca de 1915 - embora não tão calamitosa quanto às de 1877 e 1904 - "responsável" pelo êxodo de mais de seis mil norte-rio-grandenses para o norte e sul do país e pelo prejuízo de mais de $70 \%$ na pecuária, como afirmou o governador que sucedeu Alberto Maranhão entre 1914 e 1919 , o ex-desembargador Ferreira Chaves. ${ }^{75}$

Embora essas explicações sejam importantes, não se pode deixar de mencionar que elas se imiscuem nas disputas da época e revelam, assim, os rearranjos de poder na máquina administrativa estadual, a troca de acusações, a busca por reconhecimento em meio a um quadro de "transição" política que só se estabilizaria com a assunção de José Augusto ao governo do estado em 1924. Podem ser considerados também como parte dos discursos instituidores do próprio Nordeste que, ao afirmar a condição "periférica" da cidade e do estado, ajudariam a delimitar os espaços físico e simbólico da região, para diferenciar-se, legitimar-se, tornar-se visível, reivindicar recursos. ${ }^{76}$

Logo, é principalmente a partir dos próprios limites do processo de modernização urbana que se pode compreender a série de representações de uma "crise" urbana que se seguiu. Se a parte central da cidade havia de fato se transformado ao cabo desse primeiro ciclo de reformas urbanas, afastando-se da imagem colonial indesejada, é certo que as outras partes da cidade e a maior parte da sua população permaneciam à margem desse processo, sem condições de acesso às possíveis benesses da modernização e seus signos exteriores.

\section{Representações de “crise”}

A palavra "crise" aparece pouco no conjunto de falas, documentos e, principalmente, artigos compulsados por esta pesquisa. Não obstante, ela parece adequada para discutir o

\footnotetext{
73 Esse quadro refere-se apenas aos investimentos diretos efetuados pela administração estadual; parte significativa dos recursos do empréstimo foi repassada às empresas concessionárias, como em 1910, quando a Empresa de Melhoramentos de Natal recebeu o repasse de aproximadamente 900:000\$ (novecentos contos de Réis) para a consecução das obras e serviços a seu encargo: construção da usina elétrica, implementação do bonde e da iluminação elétricas e de uma rede telefônica, construção de um balneário na praia da Limpa, de fornos de incineração do lixo, etc.; somadas as duas rubricas, foram gastos apenas nas obras públicas de Natal pelo menos 40\% do valor do empréstimo captado (Cf. Maranhão, 1910, p. 17-20; 1911).

${ }^{74}$ De uma exportação de 13 mil toneladas em 1888, cujos valores atingiram mais de 1.300 contos de réis, em 1891 (para 14.323,32 toneladas exportadas), e 1.200, em 1897 (para 9.557,251 toneladas), houve uma depressão acentuada até 1913, com apenas 15,09 toneladas exportadas. Mesmo com a recuperação posterior, a produção e a exportação do açúcar não conseguiram atingir os mesmos patamares do final do século XIX: em 1928 foram exportadas 4.944,48 toneladas, pouco mais de um terço do que já havia sido produzido no auge dessa cultura (Souza, I., 1989, p.40-46).

${ }^{75}$ Ferreira Chaves, 1916, p.05-10.

76 Albuquerque Jr., 2001.
} 
período que se seguiu ao fim da segunda administração de Alberto Maranhão. Afinal, mesmo pouco nomeada, a noção de "crise" permeia muitas das representações que tematizaram o quadro de precariedade dos equipamentos e serviços urbanos até o início da década de 1920.

Contudo, deve-se ressaltar que essa noção de "crise" não tinha um significado unívoco e nem mesmo atendia a interesses coordenados; ao contrário, muitas vezes aparecia em discursos opostos, cujo único ponto de aproximação era a discussão sobre a cidade. Mesmo assim, as expressões sobre essa crise se avolumaram, exacerbaram-se no "atraso" da vida social e cultural e de certa forma ganharam às ruas, em especial com os motejos sobre o bonde e sobre o tema da cidade do "já teve". ${ }^{77}$

Essa noção poderia referir-se tanto ao sentimento de não acomodação, de insatisfação, às vezes mesmo de impotência, frente às dificuldades em acalentar o sonho de construção de uma cidade moderna, como repetiria um cronista anônimo, ainda em 1912, que não conseguia se conformar:

\begin{abstract}
"Com o monte de lixo feito diariamente no pé da calçada do mercado do lado do quartel general, pelos respectivos negociantes. Com a innundação na Ribeira, quando cai qualquer chuvada. Com immundicie na rua Gonçalves Dias; [...]. Com o bond de burro que ainda funciona para o extinto prado. [...] Com o Polytheama, sem ventiladores, não obstante seja uma casa tão decente". ${ }^{78}$
\end{abstract}

Ou ainda à percepção da transição por que a cidade passava, que saudava as inovações tecnológicas, mas repreendia o abandono da sociabilidade recatada e os valores tradicionais da pequena cidade do século XIX e, mais ainda, a adoção de hábitos urbanos considerados muito liberais e indecorosos. O lamento conservador se fazia ouvir, mas resignava-se frente à considerada marcha inexorável do progresso:

\footnotetext{
"As sympathicas filhas desta terra, minhas gentis patricias, ainda não estão de todo contaminadas do elevado grau de adiantamento das bellas cariocas. O Rio é o foco onde as filhas das outras cidades vão beber as modas, que ás vezes é alli exagerada. Ellas se addaptam logo ao meio bastante corrompido da capital federal e cahem depois em sua terra como elemento de progresso na arte feminina nocivo e perigoso para as suas amigas que ao dar-lhes as boas vindas observam-nas dos pés as cabeças [...]. Hoje, com a evolução da terra potyguar que se civilisa, ellas começam a perder a sua encantadora simplicidade de encarar a moda para se receber sorridentes, cheias de alegria, os ridiculos modelos dos figurinos. Já se namora em Natal, com bastante perfeição. Tempos atraz, não muito longe, a timidez era o caracteristico de nossas senhoritas, [...]". ${ }^{79}$
}

A “crise" era expressa também nas críticas acerbas que punham em xeque a forma como se dava - ou às vezes mesmo a necessidade de - o processo de modernização. Para quê o bonde e a energia elétrica, se a cidade não tinha condições de mantê-los, questionavam alguns editoriais do Diário de Natal em 1910.

\footnotetext{
"Para justifica que o diário se manifestou contrário aos melhoramentos dos esgottos e abastecimento d'agua, o 'orgam' da orligarchia [A República] citou a seguinte phrase que diz termos empregado em um dos nossos artigos analysando os contractos feitos pelo dr. Alberto [Maranhão]: Natal não está ainda em condições de ter luz e bondes electricos. [...] Que é que tem esta proposição com os projectados serviços
}

\footnotetext{
77 Cf. o capítulo II.

78 "Não posso me conformar", O Martelo, Natal, s/n, p.2, 02 jun. 1912.

79 “As natalenses". O Alfinete, Natal, n.1, p.1, 05 dez. 1915.
} 
de esgottos e abastecimento d'agua á esta capital? Com relação a estes serviços nós dissemos que elles eram necessários, indispensáveis e que urgiam ser feitos mesmo com algum sacrificio por parte do estado. [...] Quando a luz e bondes electricos dissemos que Natal não estava ainda em condições de tel-os e dissemos uma verdade. Cidade pequena, pobre, mal edificada com ruas esburacadas e de casebres ordinarios era uma extravagancia illuminal-a á luz electrica, tanto mais já se tendo um serviço de illuminação a acetylene montando e funcionando regularmente". ${ }^{80}$

Representações de "crise" que nos permitem desvelar os interesses conflitantes, as fissuras na aparente homogeneidade do "projeto" urbano das elites locais. Afinal, a reforma da cidade, a introdução de inovações técnicas e a criação e manutenção dos serviços e equipamentos urbanos foram tomados como objetos privilegiados no campo político de legitimação e discussão que - apesar do autoritarismo e das práticas violentas que caracterizaram as ações dos grupos políticos dominantes ao longo da Primeira República ${ }^{81}$ - se constituiu desde o final do século XIX, principalmente nas páginas dos periódicos.

No Rio Grande do Norte, O Diário de $\mathrm{Natal}^{82}$ foi um dos poucos, e talvez mais importante, veículo de imprensa a ocupar o campo oposto das falas e dos projetos oficiais, cujo porta-voz era o jornal A República. Originado da folha semanal "O Nortista" (publicado entre 1892 e 1895), o Diário marcou a posição dos setores e intelectuais descontentes com a República. Já em seus primeiros números ironizava o pretenso democratismo do novo regime, afirmando: "Essa Republica não nega a origem de uma verdadeira fidalguia burgueza que tem e que disfarça". 83

Os ecos de uma crítica nostálgica da monarquia, anti-moderna ou mesmo antiurbana, que marcara pelo menos a linha mestra inicial das formulações impressas no jornal, ${ }^{84}$ cederiam cada vez mais espaço, na primeira década do século XX, ao questionamento sobre a forma como se processavam as transformações urbanas. Nada escapou à pena mordaz e ácida impressa no Diário: nem a Cidade Nova, intitulada "Cidade das Lágrimas", alcunha que, ao denunciar a expulsão das centenas de pessoas que ocupavam o "matagal" que daria lugar ao novo bairro, sintetizou, pode-se afirmar hoje, o custo social, o caráter autoritário, excludente e segregador deste primeiro ciclo de reformas urbanas; nem as obras de calçamento, de drenagem, os serviços de limpeza, os espaços urbanos reformados e transformados em símbolos da cidade moderna em construção - como a Praça Augusto Severo; a malversação no uso dos recursos públicos; o desvio de materiais importados da Europa; a insignificância das reformas frente à receita auferida por meio de impostos considerados exorbitantes; ou mesmo a competência do arquiteto Herculano Ramos. ${ }^{85}$

\footnotetext{
80 “Triste situação", Diário de Natal, Natal, n.1250, p.01, 10 ago. 1911.

81 Cf. Carvalho, J., 1987; sobre as práticas políticas dos Albuquerque e Maranhão, Cf. Bueno, 2002, e Souza, I., 1989.

82 Este Diário de Natal a qual nos referimos circulou entre 1895 e 1913; existiram outros três com o mesmo nome (a única variação é a utilização da partícula "do" no lugar do "de"), mas sem relação de continuidade: um, o primeiro periódico diário que circulou em Natal, durou apenas dois meses de 1893 (Cf. Fernandes, 1908, p.95); outro, de orientação católica, circulou entre 1924 e 1932, quando foi transformado n’A Ordem, folha diária vespertina mantida pela igreja local; por fim, o Diário de Natal, ainda em atividade, criado em 1939 e vinculado aos Diários Associados (Cf. Cascudo, 1947, p.335-336).

83 (assina "Breakista"). "Estrada de ferro de Natal a Nova Cruz." O Nortista, São José do Mipibu, n.08, p.04, 25 mar. 1892

84 Possivelmente tributária das posições do seu proprietário e redator-chefe, Elias Souto; nascido em Assu-RN, em 1848, foi Coronel da Guarda Nacional, membro do Partido Conservador da Monarquia, participante do movimento abolicionista e um entusiasmado jornalista, fundador de inúmeros periódicos, dentre eles "O Nortista" e o "Diário de Natal"; quando faleceu, em 1906, já era considerado o principal opositor do chamado grupo "pedrovelhista” (Cf. Bueno, 2002, p. 247-255; Oliveira, G., 1999, p.114; Cascudo, L.C., 1947, p.334-335; Fernandes, L., 1908, p.94-95, 102-103); Tavares de Lyra, um dos seus principais adversários, incluiria Elias Souto, em seu "História do Rio Grande do Norte" (1921, p.743-744), como um dos "cincoenta rio-grandenses illustres, fallecidos antes de 1910".

85 Dentre os muitos artigos do Diário de Natal compulsados no banco de dados da pesquisa, Cf. "De meu canto", n. 2974, p.01, 28 jun. 1906; "Electricos", s/n, p.02, 19 set. 1908; "Sortes' de pelotiqueiro", n. 4246, p.01, 05 ago. 1911; "A sorte delles...", n. 4249, p.01, 06 ago. 1911; "Lágrimas de crocodilos", n. 4250, p.01, 12 ago. 1911; "Ainda os melhoramentos", n.4286, p.01, 06 out. 1911; "De meu canto", n.4333, p.01, 12 dez. 1911.
} 
Se, portanto, as críticas que punham em "crise" a cidade se faziam ouvir com maior ou menor veemência - quer em chave positiva ou negativa - desde o início do processo de modernização da cidade no final do século XIX, pode-se afirmar que essas representações ganharam especificidade e contornos mais nítidos ao longo dos anos 1910 e, principalmente, no início dos 1920, a partir das discussões sobre as condições precárias dos serviços e equipamentos urbanos havia pouco instaurados. Contudo, muito mais do que pôr em questão a veracidade ou não de tais representações, o que interessa discutir é como a noção de "crise" apareceu e foi apropriada nos discursos para legitimar as novas bases do projeto de reforma urbana empreendido na década de 1920.

Mesmo assim, e embora não se proponha entrar nos meandros da história econômica, cabe uma observação sobre as bases materiais desse processo. Sabe-se que o estabelecimento e a possibilidade de manutenção e extensão "dos níveis de serviço providos pela infra-estrutura decorrem do respectivo estágio de desenvolvimento". Mais ainda, o baixo desenvolvimento específico da região, e do Brasil como um todo, a precariedade das condições de produção e reprodução social e, mais especificamente, do nível de subsistência da força de trabalho, expõem os estreitos limites inerentes à modernização no Brasil. ${ }^{86}$ Sem uma classe média urbana expressiva e com um mercado de trabalho ainda em constituição, apenas uma parcela muito pequena da população tinha condições de pagar pelos serviços urbanos oferecidos. "Também nas alturas da Lagoa Seca mora bastante operário que devido a careza do bonde, come areia todo o dia pra atingir o centro da cidade, longe”, registraria Mário de Andrade nas páginas do seu diário de turista aprendiz, quando da sua passagem no final da década de 1920 por Natal. ${ }^{87}$

Neste sentido e a despeito de uma possível má administração ou mesmo do desvio de verbas, é significativo que, apesar dos investimentos provenientes dos cofres do estado destinados a sua constituição, a Empresa de Melhoramentos de Natal se encontrasse falida já em 1912, sem recursos para a manutenção e a expansão dos serviços. A criação da ETFL (Empresa Tração, Força e Luz) em 1913 pouco alterou a situação anterior, apesar do aporte de capital dos empresários paulistas que se associaram aos concessionários de Natal.

Ao contrário, os anos seguintes foram pródigos na denúncia das condições precárias dos serviços e equipamentos urbanos. Agora havia a quem responsabilizar pela "crise" da cidade. Dos periódicos de vida curta, freqüentemente semanários humorísticos, às falas oficiais das mensagens de governo ou aos artigos dos jornais com estrutura consolidada, como A Imprensa, ${ }^{88}$ tornaram-se comuns as imprecações contra a ETFL:

\footnotetext{
"Jamais cansaremos de clamar destas columnas, contra os abusos da Empreza Tracção, Força e Luz. Factos Recentes levam-nos a endereçar estas linhas, com vistas ao Dr. Honorio de Barros, gerente da mesma, que parece 'philosophar' ás reclamações populares. Agora mesmo s.s. deu-se ao luxo de mandar arrancar solipas [dormentes dos trilhos], deixando pedregulho entulhando as ruas por conseguinte prejudicando os transeuntes". ${ }^{89}$
}

A persistência nesse quadro de precariedade começava a pôr em risco, formulava-se, os padrões urbanos "civilizados" minimamente alcançados; pior, o estado da salubridade pública permanecia preocupante, mesmo sem a eclosão de epidemias ou endemias:

\footnotetext{
${ }^{86}$ Embora discuta a crise dos anos 1980 no Brasil, a premissa apresentada por Csaba Deák (1999, p.21) nos é útil para compreender esse contexto de "crise" dos serviços urbanos em Natal.

87 Andrade, M., 1976, p.259, "Natal, 2 de janeiro [de 1929]".

88 Jornal de propriedade do Coronel Francisco Cascudo, pai de Câmara Cascudo, onde este iniciou suas atividades jornalísticas, alguns esboços ainda do que viria a se tornar uma pesquisa etnográfica consistente, além de suas primeiras elucubrações e críticas literárias; o jornal circulou entre 1914 e 1926.

89 "Inqualificavel - A Empreza Tracção, Força e Luz, enscena. O gerente "philosopha". A Avenida, Natal, n.1, p.2, 12 jul. 1914.
} 
“A Empreza Tracção Força e Luz que em hora aziaga para a nossa capital, encampou os serviços de abastecimento de agua e luz e transporte urbano e remoção do lixo dos domicilios, [...], tem vindo nesse crescendo inadjectivavel de relaxamento e de descaso pelos direitos do publico a que serve, até ao ponto de, como agora acontece, suspender, em pleno inverno, por cerca de vinte dias já, o serviço de remoção do lixo dos domicilios.

Este facto escandaloso para o qual se invoca a justificativa comica e immoral de uma crise de burros na empresa (!) [...]. Semelhante desmando põe, [...], em perigo a salubridade publica, a vida dos habitantes da cidade, [...].

O lixo exposto às chuvas constantes do inverno que atravessamos, em caixões abertos, fermenta, apodrece, desenvolve gazes lethaes, cria enxames de moscas, o que tudo vae atacar a vida do natalense, [...]. Os animaes de tiro da Empreza, pobres burros lazarentos, baixaram ao hospital, [...]. Natal tem visto crescer o seu coefficiente de mortalidade, à medida que cresce a incuria dessa Empreza."

Quem quer que penetre nas officinas [da usina elétrica] do Oitizeiro surprehende-se logo por uma grande alteração na perspectiva daquelle recanto nemoroso. É effeito de um hymalaia de lixo que se ergue ali dentro barrando o horizonte e atirando na atmosphera uma tromba de gazes densos, mephiticos, podres, que vão malignal-a e diffundir os miasmas terriveis da fieuvre jaune". ${ }^{90}$

Os textos que tematizam essa "crise" se avolumaram e acabaram construindo um quadro de retrocesso e de pessimismo. ${ }^{91}$ As pessoas pareciam se perder em meio a tanto mato, capim e monturos de lixo que se acumulavam pela cidade. Os bondes, além de não atenderem a demanda, desmanchavam-se ao longo dos trajetos, deitando por terra a sua fiação elétrica, trazendo riscos à vida dos pedestres e usuários dos veículos. ${ }^{92}$ Os logradouros públicos sofriam na mesma desatenção, mesmo aqueles que haviam sido construídos e tomados como símbolos das primeiras reformas urbanas do período republicano, dos esforços de superação do dito atraso da estrutura, imagem e hábitos da cidade colonial, como o jardim da Praça Augusto Severo: "Aquelle logradouro há muito tempo constitue um fóco perigoso de mosquitos, devido a lama, que arrastada pelas marés de enchente, se accumulam no leito causando exhalações putridas, sendo os transeuntes obrigados a levar o lenço ás narinas". ${ }^{93}$

As interrupções no fornecimento de energia eram constantes, o que afetava diretamente, além do funcionamento da iluminação pública já considerada precária, o abastecimento d'água, o transporte coletivo e, inclusive, a circulação dos jornais. ${ }^{4}$ Se esta precariedade era evidente mesmo nas áreas valorizadas pelas elites, quer de moradia ou de lazer, os serviços de água, luz e limpeza públicas eram "uma trindade de utopias para os moradores das areas mais afastadas". ${ }^{5}$

"Não é de hoje nem de hontem que se tem chamado, pelas columnas de alguns jornaes, a attenção de quem de direito, para o completo abandono em que se encontra a rua Cabugy.

\footnotetext{
90 Pereira, 1916.

${ }^{91}$ Cf. Soares, 1999 , cap. 2.

92 “Tópicos \& Notícias", A Imprensa, n.1416, p.02, 19 out. 1919; Mello e Souza, 1920, p.40.

93 “Topicos \& Noticias", A Imprensa, n.1371, p.01, 28 ago. 1919.

94 “Agradecemos o atraso da circulação desta folha, logo pela manhã, a essa empresa macabra e fraudulenta sob a gerencia deste italiano desconhecido, que se chama Americo Gentil. Hontem, o bairro da Ribeira ficou as escuras desde as quatro horas, causando com isso, prejuizos a todos que tem luz em suas residencias, principalmente aos jornaes que circulam pela manhã. Interessante, é que, o bairro preferido é sempre o da Ribeira...". In "Empresa Força e Luz - Uma vergonha para nós!...", Natal Jornal, n.1, p.2, 04 maio 1919.

95 Natal Jornal, n.1, p.1, 04 maio 1919.
} 
Si bem que não seja onde as principais arterias, não deixa de ser, [...] uma rua da capital. Ladeirosa, sem nenhuma hygiene, pois o matagal ultimamente cortado, não foi, nem siquer, retirado, verificando-se assim, o seu completo apodrecimento.

Alem disto, è uma rua exquisita, quasi intransitavel, porque, devido as grandes enchurradas, seu leito está transformado em barrocas, grutas ou cavernas, as mais horriveis que se pode imaginar!

Quem se atreverá a passar pela rua Cabugy, a noite ou mesmo de dia?! É um precipicio, é um perigo de vida; [...]". ${ }^{96}$

A situação chegou a tal ponto que até mesmo a greve dos operários da ETFL, em 1919, encontrou respaldo na imprensa e a aquiescência do governo estadual. Insatisfeitos com as chamadas medidas abusivas praticadas pela direção, como os preços extorsivos dos víveres vendidos no "Barracão", a cobrança da passagem dos funcionários que tomavam o bonde para ir almoçar em casa ou que faziam o caminho de ida e volta do trabalho e os baixos salários, os operários dos diversos setores da Empresa - limpeza pública, usina elétrica, transportes públicos, etc. - pararam todas as atividades. Sem respaldo público ou governamental, os diretores da Empresa desistiram das medidas e aumentaram os salários de seus empregados. "A cidade esteve ameaçada de ficar hontem às escuras, caso o Sr. [Américo] Gentil não tomasse o bom alvitre de capitular ante a indignação do operariado vilmente explorado pela Empreza". ${ }^{97}$

Tanto a propriedade da Empresa, no Oitizeiro, onde ficavam as oficinas de manutenção, os fornos de incineração do lixo e a usina elétrica - uma área "pantanosa e coberta de viçoso capinzal" (figura 08) - quanto a saúde de seus funcionários, constantemente acometidos pelas endemias de inverno, o impaludismo e a febre amarela, eram tomados como um retrato da penúria em que se encontrava o espaço urbano de Natal. Mesmo atendendo e clinicando constantemente, como médico da Empresa, Januário Cicco admitia que pouco podia fazer frente às más condições de trabalho e habitação que degradavam o ambiente:

\begin{abstract}
"Não é sem o meu protesto que a Empresa mantém aquele viveiro de morte; propuz o seu saneamento e a prophylaxia preventiva, desde que assumi a responsabilidade de cuidar daquella bôa gente, mas até hoje continua no mesmo estado o pantanoso capinzal, e, endemo-epidemico, o impaludismo alli vae ceifando vidas preciosas á familia e á Patria.

Custava tão pouco, numa area relativamente pequena, fazer o deseccamento do estreito valle, canalizando as aguas empoçadas, por uma serie de valletas ao Oitizeiro, que se não pode perdoar tamanha indifferença pela vida dos que teem a infelicidade de residir e trabalhar naquellas cercanias." 98
\end{abstract}

A amiúde interrupção no fornecimento de energia, devido às precárias condições técnicas (e sanitárias) da Usina Elétrica do Oitizeiro, tornou cada vez mais insustentável a atuação e o contrato da Empresa com o governo do estado. Isto acarretaria na rescisão do contrato já no primeiro ano do mandato do governador Antonio José Mello e Souza (19201923), com a penhora de parte das rendas e bens da Empresa para o pagamento das multas contratuais.

"Desde muito tempo eram maus quasi todos os serviços, de que se incumbira por
contracto a Empresa de Tracção Força e Luz desta capital. No principio do
corrente anno, alem de defficientes, verifiquei serem tambem onerosos, porquanto

${ }_{96} \mathrm{~S} / \mathrm{t}$, "Dirigida ao Sr. Governador do Municipio", A Pua, Natal, n.1, p.2, 21 nov. 1920.

${ }^{97} \mathrm{~S} / \mathrm{t}$, "Greve dos operarios da E. T. F. e Luz - o Sr. Gentil capitula", A Imprensa, Natal, n.1417, p.01, 21 out. 1919.

${ }_{98}$ Cicco, 1920 , p.33. 
somente a illuminação publica estava custando ao Thesouro cerca de 110 contos de réis quando o teto orçamentario era de 66 contos." [Devido à diversas medidas de economia, como a instalação de medidores nos edifícios públicos, o estado conseguiu economizar um gasto que estava em 62:437\$ para 48:000\$]. "Infelizmente o estado dos fios conductores da energia electrica para os bondes não permittia que essa paciência fosse de longa duração. Esses conductores partiam-se frequentemente em plena rua, o que constituia um grave perigo para a população, cujas reclamações se amiudavam". ${ }^{99}$

Enfim, no início da década de 1920, tal sentimento de retrocesso, de efemeridade, espraiou-se da "crise" dos serviços e equipamentos urbanos para as várias esferas da vida social, colocando, em várias formulações e por meio de várias vozes, uma situação-limite que interpelava a sua própria condição de cidade, como transparece nesse artigo sobre os cinemas de Natal:

"Natal é uma especie de enfermo desenganado. Cada dia, cada hora, a sua situação se aggrava, e todos os meios empregados para evitar o seu desaparecimento se vão tornando improficuos. Deixamos a parte as suas pessimas condições hygienicas e voltemos agora as nossas vistas para os seus generos de diversão.

Temos ha muito tempo dois cinemas: Polytheama e Royal, ambos de propriedade do sr. Americo Gentil e arrendados ao sr. Alberto Leal, que ha annos, explora em nossa terra esse ramo de negocio. O Royal, situado em um dos principais pontos do bairro alto, alem de ser um verdadeiro alojamento de pulgas, permitte a entrada de grande numero de pessoas descalças, dando-nos uma impressão de cinema de quinta ordem. O seu operador não pode ser peior; arrebenta-se a fita de minuto a minuto; a molecada entra a assoviar o que a pianista está assoprando; as pulgas dmordem as pernas dos espectadores; a meninada bate palmas e dá gritos que ninguem se move, não ha quem tome providencias para cessar taes abusos.

O Polytheama, se bem que menos frequentado, é quasi a mesma coisa. Dizem que embaixo do palco há lixo para um dia de transporte nas carroças da limpesa publica. [...]. Enfim, os dois unicos estabelecimentos de diversão de nossa capital estão prestes para entrar para a galeria do 'já teve' se o sr. Americo Gentil não rescindir o contracto ficando ele mesmo com suas casas". 100

Os bondes foram possivelmente a melhor expressão dessa "crise", tornando-se matéria constante nos periódicos, principalmente depois da eletrificação das linhas, em 1911. Se os bondes eram para alguns a "alma da cidade" (figuras 09 e 10), dessa nova cidade em transformação, por meio dos quais era possível senti-la pulsar, vibrar, adivinhar-lhe os estados de espírito, acolhendo a todos "sem distinção de classe, de cor ou de política", enfim, sem os quais a nova cidade não tinha vida; ${ }^{101}$ o seu funcionamento constantemente precário era, por conseguinte, constitutivo da "crise" da cidade em formação.

A intermitência do pulsar desta alma, o bonde, no caso, não é nem metáfora nem retrato, metonímia talvez, das frágeis bases técnicas em que se assentava este processo de modernização; é expressão dessa condição débil que impedia o funcionamento minimamente razoável dos serviços de tração urbana e de iluminação pública e, pior, para o olhar médico, do bombeamento do sistema de abastecimento d'água da cidade.

"Não sei como pudemos viver tanto tempo sem elle!", afirmaria um cronista anônimo de 1923, percebendo com sutileza a potencialidade de mudança na introdução desses melhoramentos e novas tecnologias, levando a, mesmo numa pequena cidade como Natal,

\footnotetext{
${ }^{99}$ Mello e Souza (Mensagem de Governo), 1920, p.38.

100 "Cinemas". Jornal do Norte, Natal, n.1, p.2, 17 jun. 1921; grifos nossos

101 "O bond". A República, Natal, n.217, p.01, 23 set. 1923.
} 
novos ritmos, novas dimensões e formas de apreensão da cidade: das errâncias no espaço restrito da cidade colonial às novas velocidades, extrapolando pouco a pouco os seus limites físicos, e às novas sociabilidades no contato próximo "entre toda sorte de passageiros, com suas palestras, informações, bisbilhotices", forjando a "psycologia de uma população". ${ }^{102}$

Assim, ao pôr em "crise" a cidade, tais representações constituíram o esteio das discussões que propugnavam a rearticulação de um novo projeto de modernização urbana para Natal. Tornaram mais vivos e exacerbaram os anseios pela construção de uma cidade moderna. Ao mesmo tempo, e apesar da responsabilização da ETFL, a noção de "crise" naturalizou a leitura desse processo. Transformou em um mero problema de má administração ou desatenção na gestão dos serviços e equipamentos urbanos o que, na verdade, encontra suas raízes na estrutura social extremamente desigual e no processo de modernização elitista e excludente brasileiros. O que, no final, desresponsabiliza a todos. ${ }^{103}$

A partir de então diversos esforços foram envidados para reorganizar os serviços urbanos e melhorar as condições de salubridade da capital. A aparente estabilidade do estado sanitário não resistiu à primeira grande irrupção epidêmica; as demografias sanitárias e os altos índices de mortalidade desvelavam e ao mesmo tempo espacializavam as endemias do seu espaço urbano. Foi dentro desse quadro, e para responder a ele, a partir da codificação da realidade em dados que podiam ser comparados sincrônica e diacronicamente, que o médico Januário Cicco construiu a sua topografia e geografia médica de Natal. Uma crítica, se é permitido dizê-lo, que se juntou ao clima decadentista e pessimista que perpassa a leitura dos vários jornais na virada para a década de 20 , à imagem da cidade do "já teve" e do efêmero. Contudo, esta crítica não se funda nas exterioridades e signos de uma civilidade burguesa; antes de mais nada, é um esforço de compreensão abrangente do espaço e da vida urbana, incluindo aí, principalmente, as condições de vida das classes populares, sua habitação, alimentação e (falta de) hábitos higiênicos.

\section{Como higienizar Natal}

Depois da devastação de milhares de vidas devido à influenza, em 1918, Carlos Chagas, Diretor Geral da Saúde Pública brasileira, fez circular um telegrama entre todos os Inspetores de Saúde dos Portos do Brasil solicitando as medidas necessárias a cada localidade para conter o avanço de novas epidemias de alcance mundial. Para Januário Cicco, Inspetor da Saúde do Porto de Natal, não era necessário nada de novo, exceto a execução do artigo 56 do Regulamento Geral de Saúde Pública, de 1914: "no laconismo da minha resposta quis affirmar que nenhuma disposição regulamentar, nem outra qualquer medida prophylactica seria capaz de nos premunir com tanta segurança como a creação dos serviços de defesa, constantes daquele dispositivo de lei". ${ }^{104}$

Contudo, ao contrário de países como os Estados Unidos, a Inglaterra, França e Itália, onde "a legislação sanitaria attinge os limites da perfeição", o Brasil permanecia à mercê de um "indifferentismo morbido", de uma incúria administrativa de "estadistas de ultima hora", que constrangiam as repartições e órgão de higiene e saúde pública com "politicalhas" e deixavam as cidades dependendo da "vontade augusta dos Deuses do Olympo", ${ }^{105}$ como o caso de Natal mostrava-se exemplar, onde as benesses das condições climáticas apenas impediam o pior:

"A despeito das vantagens do nosso clima e comquanto pareça paradoxal, Natal é uma cidade onde muito se morre.

102 Ibidem.

103 Cf. Telles, 1999.

${ }^{104}$ Cicco, 1920, p.04; este Regulamento foi sancionado pelo Decreto Federal n. ${ }^{\circ} 10.821$, de 18 de março de 1914.

105 Ibidem, p.04-05. 
A sua população de 22 mil habitantes deveria dar um coefficiente minimo de lethalidade, e no emtanto a cifra do obituario de Natal espanta, causando serias apprehensões, principalmente si se procura balancear a natalidade”. ${ }^{106}$

Enquanto sua crítica mais geral às condições e à política de saúde pública no país era amiúde mordaz e irônica, a apreciação das condições locais exigiu-lhe maiores cuidados e ressalvas, construindo-se por força do diagnóstico da cidade, por meio da sua topografia e geografia médicas. Cabe então acompanhar como a cidade apareceu no discurso médico, desdobrando as configurações históricas e administrativas, observando as subdivisões dentro de cada bairro a partir de suas formas próprias de assentamento e das suas endemias particulares. Assim, constituía-se uma nova forma (de divisão) do espaço urbano que esquadrinhava os seus meandros e revelava alguns núcleos que estavam encobertos nas generalizações oficiais.

A área urbana da cidade dividir-se-ia, grosso modo, entre a Cidade Baixa ou Ribeira e Cidade Alta. Contígua à primeira, mais ao norte e separada apenas por uma faixa de 400 metros - sobre a qual seria expandida a Ribeira, a partir do Plano Geral de Sistematização -, fica o bairro das Rocas. A Cidade Alta, o platô elevado de ocupação primeira da cidade, estende-se a leste até a Cidade Nova, desdobrando nos bairros de Petrópolis e Tirol, e ao sul até o Alecrim; este último, por sua vez, podia ser subdividido em Baixa da Beleza, Boa Vista e Refoles. ${ }^{107}$

O esquadrinhamento minucioso do espaço urbano pelo higienista, diria Cicco, assemelhava-se aos preparativos de um general para a guerra ou de um engenheiro para uma obra - não se podia avançar sem um reconhecimento prévio da situação, sem um projeto que "estuda os motivos de exito, traça na carta geographica o ataque ao inimigo, e, emquanto lhe resta outra melhor hypothese de victoria, não expõe os seus soldados ao infortunio de uma derrota" ${ }^{108}$ Assim, antes da proposição de soluções, partia-se para a busca acurada de reconhecimento do território e das condições culturais da população, incorporando os novos estudos etiológicos e a microbiologia à concepção do meio como elemento propiciador de endemias, moléstias e irrupções epidêmicas. A preocupação com as fontes de abastecimento, com as lagoas e, fundamentalmente, com a estagnação das águas era retomada com veemência, não mais pela exalação de gases pútridos, os miasmas, mas pelos focos, larvas, mosquitos, que encontravam ambiente propício no lodo, na lama ressecada, nas poças e olhos d'água, em todo o meio líquido que estivesse parado.

Embora a teoria miasmática tivesse refluído e sido praticamente desconsiderada com as pesquisas de Pasteur, a concepção mesológica perduraria no século $\mathrm{XX}$, como pode ser comprovado nas proposições e nos projetos do engenheiro Saturnino de Brito ${ }^{109}$ ou mesmo na topografia e geografia médica de Cicco. Atualizando os conhecimentos médico-sanitários por meio dos avanços da teoria microbiana, Cicco retomava essa concepção para compreender a insalubridade da cidade e da região, construindo uma relação estreita entre o ambiente urbano ou rural, as moléstias e os hábitos da população.

\footnotetext{
“A relação que existe entre as moléstias e a região onde se desenvolvem tem ainda como factores etiologicos as condições individual e collectiva, notando-se que nos bairros operarios de Natal são aggravantes á etio pathogenia, como predisponentes, a falta de hygiene corporal, as habitações insalubres, o excesso de habitantes em cada domicilio e a viciação do ar, decorrente daquella promiscuidade". ${ }^{110}$
}

\footnotetext{
106 Ibidem, p.14.

107 Ibidem, p.07-08.

108 Ibidem, p.21.

109 Andrade, 1992, p.27.

${ }^{110}$ Cicco, 1920, p.13.
} 
Por isso, as medidas profiláticas, as vacinações e revacinações, as desinfecções, o esforço do médico no embate diário pela cura dos seus pacientes, pouco podiam frente à falta de educação, a falta de uma cultura higiênica, de habitações salubres e a inexistência de uma rede eficiente de abastecimento d'água e de dejeto dos esgotos, afirmaria Cicco. "Si o Governo quizer amparar efficientemente o seu povo, servindo as populações de rêdes de esgoto e não regateando despesas para a instrucção official no Brasil, em futuro mais proximo a miseria terá desaparecido, na razão directa da prosperidade do paiz". ${ }^{111}$

Não seria, ou não se pretendia, que o saneamento e a higiene fossem realizadas como nas reformas urbanas conduzidas pelo engenheiro Pereira Passos, parte de um projeto maior de modernização impetrado pela elite dirigente, e que teve na "Revolta da Vacina" um dos seus episódios mais contundentes. A modernização do espaço urbano, por meio da "ditadura Passos" e da "ditadura sanitária", desvelava um projeto civilizatório excludente que repunha as diversas práticas de repressão e punição do período colonial, como o chicote para lacerar a carne dos revoltosos, identificando-os, assim, socialmente e mostrando a sua submissão à ordem, da mesma forma que a marca da vacina significaria a prostração à autoridade sanitária. Sevcenko revelaria na leitura da "Regeneração" de Passos a conformação de um espaço ordenado que segregava e separava, impondo grades, prisões e açoites, morais e físicos, aos indesejados, ao rebotalho vagabundo que se entremeava e sobrevivia, mesmo antes das reformas, nas entranhas do centro da cidade. ${ }^{112}$

Cicco, então, ao propugnar a necessidade inconteste de fazer as águas circularem, de reformar o espaço urbano a partir da reforma da habitação, principalmente das classes populares, e da mudança e introdução de novos hábitos que tinham a higiene como eixo central, não estava afastado do ideal de disciplinamento, da organização e do governo racional da cidade, que era o oposto utópico da "cidade pestilenta". ${ }^{113}$ Procurava, talvez se possa afirmar, a "disciplina suave" do "conforto civilizado", que não reprimiria ou proibiria, mas substituiria as formas de satisfação corporal do "conforto selvagem". ${ }^{114}$ Ao invés da promiscuidade - lida no adensamento demográfico do bairro do Alecrim, na convivência indesejada da lavagem de roupas, corpos e animais em logradouros públicos como o Baldo, ou nos comportamentos considerados indecorosos e degradantes, como o alcoolismo e a prostituição no Passo da Pátria - o conforto dos fluidos em circulação. Em especial, o conforto da água tratada que chegaria através das tubulações do sistema de abastecimento, e da rede de esgotos que, ao canalizar e eliminar os dejetos, ajudaria a evitar o contato com a sujeira e os excrementos presentes no solo contaminado pelas fossas negras ou pelas simples cavas superficiais onde se enterrava até o entulho acumulado pela limpeza pública.

Confortos que a cidade não contava ou mal dispunha, mesmo nos ditos espaços civilizados construídos para o usufruto das elites. O serviço de abastecimento d'água, existente desde 1882, era "detestavel", diria Cicco. Proveniente de um tanque circular que recebia águas de nascentes próximas, cujos terrenos eram "pantanosos, cobertos de capim e farta vegetação", o abastecimento da cidade estava sob risco constante:

"Como já tive occasião de dizer, a captação d'agua dessas fontes é feita por bombas
e levada a um grande reservatorio circular, coberto de telha metallica e protegido
por uma tela de grandes malhas. As suas paredes foram revestidas a cimento e o
tempo abriu-lhes lojas onde moram sisudos sapos, respeitaveis cobras, e se divertem
as lagartixas. O pó e as folhas seccas alli conduzidas pelo vento entreteera uma certa

111 Ibidem, p.14.

112 Cf. Sevcenko (marcado pelo Foucault de "Vigiar e Punir"), 1984.

113 Andrade, 1992, p16.

${ }^{114}$ Cf. Beguin, 1977; sabe-se que Saturnino de Brito preconizava um "higienismo pedagógico", em oposição ao "higienismo despótico" à Oswaldo Cruz (Cf. Andrade, 1992, p. 235). 
decomposição, mantida ainda pelo corpo de algum daquelles animaes que tem a desventura de se sepultar no liquido precioso.

Pois essa agua assim, sem outro beneficiamento, é levantada por bombas, conduzida ao serviço de abastecimento e usada pela população, que, graças a Deus, ainda está vivissima!"115

O Baldo - na zona intermediária entre a Cidade Alta e o Alecrim - permanecia, na avaliação de Cicco, como um foco de doenças do aparelho gastro-intestinal, onde proliferavam mosquitos transmissores da malária. Apesar de ser uma das fontes principais da cidade, as formas tradicionais de uso do espaço público a condenavam: "Nessa lagôa dão de beber ao gado leiteiro, banha-se gente do povo, lava-se roupa e se refrescam os animaes de serviço".

Para Cicco, a limpeza das principais ruas e praças de Natal era uma farsa, "murmurando-se imprecações aos dinheiros gastos sem o accerto de melhores applicações", a rede de assistência pública médico-hospitalar estava "soffrivelmente installada" (o Isolamento de Tuberculosos era uma "casa sem condições de habitabilidade, humida, baixa, cujo piso repugna, situada á margem direita da Great Western e immediações do mangue, sendo mais a Ante-Camara da Morte do que o amparo [...] daquelles desgraçados") e a rede de esgotos inexistia. No seu lugar, fossas negras sem tratamento químico, cavas superficiais para o enterro da sujeira, ao redor dos terrenos e saindo às ruas e praças, quando não eram os dejetos diretamente espargidos no solo. ${ }^{116}$ Situação que se tornava mais crítica nas "casas de nosso operario":

\footnotetext{
"com o piso desprotegido e por onde se arrasta a filharada amarellenta e nua, mesclando o chão com as proprias dejecções, misturando á sujidade do local a côdea de pão que lhe cáe das mãos, não ha remedio contra as reinfecções, tonicos que reorganizem decadências, nem fossas que eduquem um povo de analphabetos". ${ }^{117}$
}

Após uma análise minuciosa de cada bairro, discutindo as especificidades endêmicas, as condições nosográficas e os problemas que eram gerais à cidade, Cicco proporia uma série de medidas em prol da sua salubridade. A circulação das águas, dos fluidos, era tomado como imperativo, seguindo a tradição higienista que continuou na engenharia sanitária, ${ }^{118}$ partindo daí a condenação das lagoas e fontes como "perigosas a vida collectiva", ${ }^{119}$ mesmo na Cidade Nova (Petrópolis e Tirol), o bairro que avaliava como o mais salubre e aprazível da capital. Contudo, a solução definitiva para o problema da saúde das cidades, de qualquer cidade com mais de dois mil habitantes, e não apenas de Natal, estava na construção de uma rede de esgotos eficiente e na educação (higiênica, moral, profissional) do povo.

A compreensão do papel central das ações higienistas e sanitaristas na reforma urbana, que teria reflexo direto na melhoria social e na elevação do padrão moral das classes populares, permeia este livro e situa Cicco no seio do pensamento do movimento higienista, propondo a reforma da vida cotidiana por meio das mudanças nos costumes e nas habitações das classes populares. A idéia das moléstias, das pestes, como elementos de desordem, de desestruturação da tessitura social da cidade, permanecia, embora agora centrada no indivíduo, devido aos avanços da teoria microbiana. ${ }^{120}$

\footnotetext{
115 Cicco, 1920, p.31.

116 Ibidem, p.21, 40; grifo nosso.

117 Ibidem, p.17.

118 Cf. Andrade, 1992.

119 Cicco, 1920, p.11.

${ }^{120}$ Cf. Andrade, 1992.
} 
Defensor de uma nova moral e pudicícia burguesas, o olhar do médico, sem dúvida elitista, não conseguia esconder a incompreensão e o preconceito em relação às práticas e estratégias populares, consideradas todas como causa e conseqüência da promiscuidade e da degenerescência. ${ }^{121}$ Ao que parecia tão afrontoso, como o Passo da Pátria, não cabia nem reforma - era a destruição pura e simples.

\footnotetext{
“Á montante do rio Potengy, e aquem do matadouro, há outro bairro de operarios, de pequeno commercio, [...], cujas condições de vida se oppõem a qualquer prosperidade. De habitações humidas, baixas, sob cujos tectos vivem promiscuamente e em excesso os seus moradores, o Passo da Patria é também uma zona de plantações de capim e de criação de porcos". ${ }^{122}$
}

O que Cicco não dizia, afinal esta descrição diferia pouco das outras acerca dos bairros populares, era que, além de capins e porcos, esta era uma zona de pândegos e de prostituição, de tudo que parecia mais corrompido ao olhar "civilizado" das elites. Um memorialista depois lembraria que, mesmo entre as meretrizes, não podia haver ofensa maior do que ser chamada de "puta do Passo da Pátria", tal a sordidez e degradação do espaço e daqueles que lá moravam. ${ }^{123} \mathrm{O}$ expurgo, "a destruição do bairro como unica medida prophylatica", apenas exacerbava o caráter autoritário da ação higienista, presente mesmo na sedução e suavidade do conforto civilizado, que era essencialmente uma busca pela renovação da "machina humana", pela elevação da sua capacidade produtiva que "a orgia, os festins e a concupiscência travaram em meio do caminho". ${ }^{124}$

Mas, para tanto, fazia-se necessário desmontar o paradoxo existente em Natal: uma cidade de clima favorável à salubridade, mas com altos índices de mortalidade. A partir da análise das séries estatísticas da demografia sanitária e da sua experiência como médico atuante na cidade desde 1909, Cicco tentaria desfazê-lo em duas ordens: uma analítica e a outra propositiva, isto é, desmontava conceitualmente algumas explicações para a insalubridade da cidade que haviam sido a escusa para diversas intervenções no espaço urbano e, por outro lado, propunha ações para a eliminação real e prática desse mesmo paradoxo.

Os dados de 1919 apontavam um obituário geral de 1093 pessoas, para uma população de 21.948 habitantes, registrando o alto índice de 49,79 mortes por mil habitantes. Ademais, mais da metade deste obituário era de crianças entre 0 e 5 anos (573 óbitos, o que significava $52,42 \%$ do total).

\footnotetext{
"Nem mesmo assim, todavia, se desvirtuam as qualidades preciosas do nosso clima, porque a ceifadora de vidas infantis não é nenhuma molestia epidemica, mas, em sua maioria, a falta absoluta de cuidados na alimentação da primeira edade, que, só por si, é bastante para entreter as gastro-enterites fataes, quando lhes não succedem as infecções, tão communs ás creanças pelo uso dos consoladores, pela alimentação de má qualidade e contactos impuros". ${ }^{125}$
}

Não eram as epidemias, enfatizava Cicco, responsáveis únicas pelo constante desequilíbrio do estado sanitário da capital. Não era um fator externo, um inimigo que prorrompia nos portos e nas estações ferroviárias, mas a má condição de vida da maioria da população, que se revelava nas habitações precárias, na alimentação pobre, na falta de hábitos

\footnotetext{
121 Rolnik, 1997; Bonduki, 1998.

122 Cicco, 1920, p.11.

123 Pinto, 1971, p.40-41.

${ }^{124}$ Cicco, 1920, p.29, 43.

125 Ibidem, p. 14 .
} 
higiênicos, fatores agravados pela deficiência do sistema de abastecimento d'água, pela inexistência de uma rede de esgotos, pela precariedade dos serviços e equipamentos urbanos.

O problema, na verdade de âmbito nacional, como demonstravam as pesquisas da missão Rockefeller no final da década de 1910, dados avalizados pela viagem de estudos de Belisário Penna, eram as verminoses em geral, e a ancilostomose, o popular amarelão, em particular, que minavam as forças do homem nacional. Um problema que atingiria principalmente as populações do campo e das cidades menores do interior, dos sertões brasileiros, o que permitia a intelectuais como Monteiro Lobato, diria Cicco, estudar as causas da decadência do Brasil no "complexo mórbido que empresta o zoo-parasitismo" à "inferioridade do homem do campo". ${ }^{26}$

O que aflora, por fim, na geografia e topografia médicas de Januário Cicco é a descrição de uma cidade onde as condições de vida e os hábitos da (maioria da) sua população ainda eram considerados pré-modernos, isto é, distante dos padrões de civilidade burguesa. As imagens dos animais ainda a chafurdar soltos no espaço urbano (um indício talvez da fluidez na separação entre o público e o privado), do lixo depositado nas ruas, da má localização do matadouro e do cemitério, dos banhos e lavagens de roupas, corpos e animais em logradouros públicos como o Baldo, das constantes inundações na Ribeira, somavam-se às dos costumes tradicionais, das festas e cantorias, da complexa rede de relações sociais construídas pelas classes populares. Testemunhava, assim a permanência de práticas do século XIX ou mesmo do período colonial que se pretendiam superadas. O que, ao lado de todas as representações sobre a "crise" que se abatera sobre Natal nesse período, impunha a necessidade de rearticulação e retomada, formulava-se, do "projeto" de modernização empreendido pelas elites locais.

A idealização de uma cidade moderna, baseada na teoria e prática médico-sanitária e na consecução de redes eficientes de saneamento, constituiu-se também como uma contraposição às outras idealizações que contemplavam apenas os signos e exterioridades da civilização burguesa. Ao construir a descrição e análise da realidade do espaço urbano, incluindo e discutindo sobremaneira os territórios populares, fez desta contraposição um documento que fala muito acerca dos significados e limites das intervenções públicas anteriores sobre o espaço urbano de Natal.

Se este documento tem uma importância que permite discutir as intervenções e propostas que lhe são anteriores, é importante observar que o conjunto de temas, análises e proposições desenvolvidas por Cicco pautariam, direta ou indiretamente, diversas e importantes ações que se estruturariam durante as duas décadas seguintes. Talvez não seja possível realmente falar em uma influência direta, apesar da ressonância dessa pequena obra na imprensa ${ }^{127}$ e da contínua atuação de Cicco como médico em Natal, mas, com certeza, numa das sínteses mais consistentes dos debates e anseios que o ambiente técnico, social e, sobretudo, cultural suscitou na virada para a década de 1920.

\footnotetext{
${ }^{126}$ Ibidem, p.15.

127 Cf., por exemplo, “A grande verdade do pequeno livro 'Como se hygienizaria Natal” (Cascudo, 1920, in Mamede, 1970, v.1, Parte 1, p.176).
} 


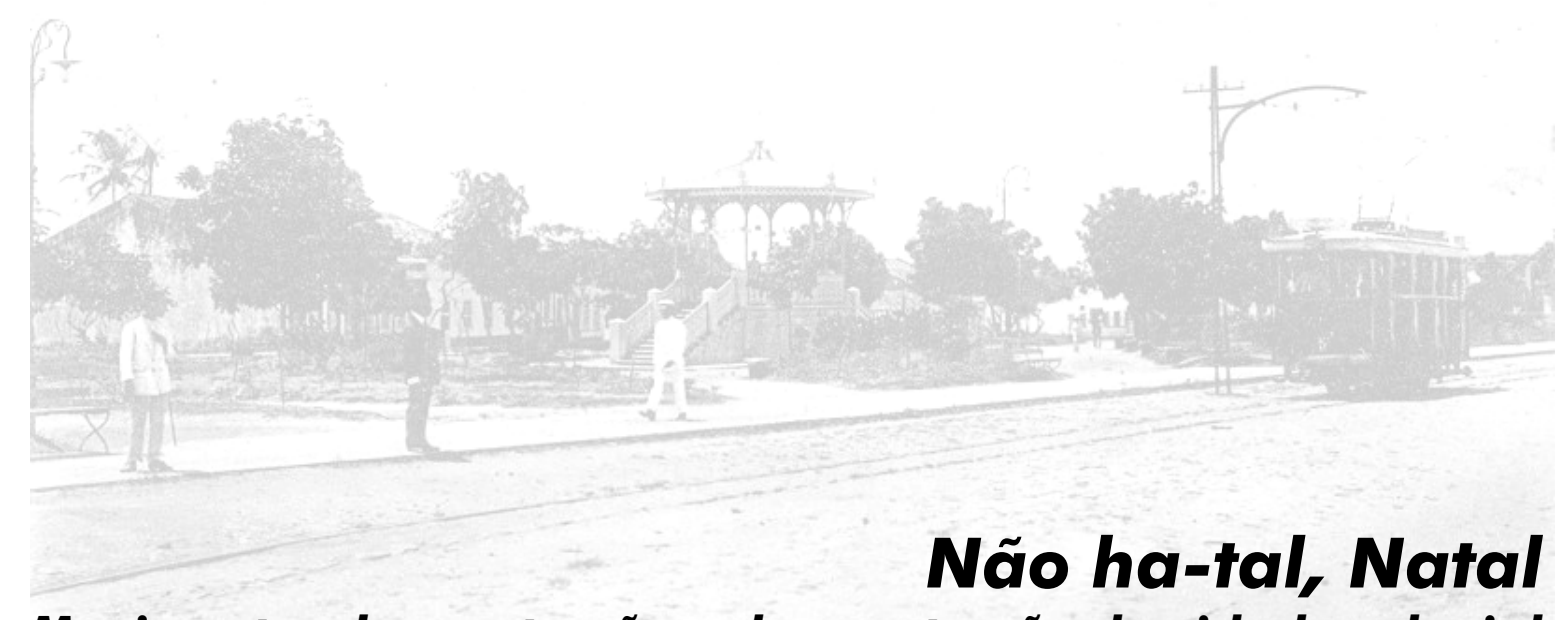

Movimentos de construçáo e desconstruçáo da cidade colonial 
Vindo de Pernambuco, onde se instalara para tratar da sua tuberculose sob os auspícios do clima dos trópicos, o português filho de ingleses Henry Koster chegou a Natal em fins de 1810. Registrando sem parcimônia tudo pelo caminho, desde as explicações para os topônimos, os costumes, o uso da rede, a tipologia habitacional ou o fausto de um jantar em uma casa-grande, não lhe escapou a aridez, a desolação e a dificuldade para chegar à capital da então província do Rio Grande do Norte por via terrestre. As dunas, em turbilhão pelo vento violento, mudando sempre de forma e posição, tornava a marcha lenta e cansava homens e animais, quer em comboios com mercadorias, quer em pequenas expedições como a de Koster. ${ }^{1}$

Contudo, chamou-lhe ainda mais atenção a condição daquela cidade chamada Natal, onde a configuração do seu espaço urbano mal se esboçava nas poucas, empoeiradas e incompletas ruas da Ribeira e da Cidade Alta, como se lê no registro espantado que deixou:

\footnotetext{
“cheguei ás onze horas da manhã á cidade do Natal, situada sobre a margem do Rio Grande ou Potengi. Um estrangeiro que, por acaso, venha a desembarcar nesse ponto, chegando nessa costa do Brasil, teria uma opinião desagradável do estado da população nesse país, porque, se lugares como esse são chamados de cidades, como seriam as vilas e aldeias? Esse julgamento não havia de ser fundamentado e certo porque muitas aldeias, no Brasil mesmo, ultrapassam esta cidade, o predicamento não the foi dado pelo que é, ou pelo que haja sido, mas na expectativa do que venha a ser para o futuro". ${ }^{2}$
}

Repetia e atualizava, assim, e de forma mais elaborada, os relatos de vários outros viajantes ou funcionários da administração colonial que passaram por Natal entre os séculos XVII e XVIII e que deram conta de sua condição precária de cidade. Em 1608, o governador geral do Brasil, D. Diogo Meneses, relatou ao Rei que a povoação havia pouco fundada não tinha "gente" (ou melhor, colonizadores brancos). Há o registro da existência de catorze casas em 1614. Sessenta em 1631. O príncipe Maurício de Nassau, no documento Sommier Discours de 1638, descreveu-a como uma cidade mui decaída. ${ }^{3}$ A paupérie da terra a alijava de maiores observações, como diria o personagem Alviano, nos "diálogos das grandezas do Brasil", do século XVII: "Deixemos logo esse Rio Grande por esteril".

O tamanho diminuto e a pouca importância de Natal que transparecem nesses relatos logo tornar-se-iam motivos para remoques entre os habitantes da porção setentrional da

\footnotetext{
1 A viagem a Natal consta no capítulo V do livro "Viagens ao Nordeste do Brasil” (Koster, 1817, p.96-117).

2 Koster, 1817, p.109-110; grifos nossos.

${ }^{3}$ Cf. Cascudo (1947, p.52-67) e a série de documentos dos séculos XVI e XVII sobre a capitania do Rio Grande transcritos por Hélio Galvão (1979, p.239-302).

${ }_{4}^{4}$ Brandão, 1930, p.43.
} 
Colônia. O sétimo bispo de Olinda, D. Antonio Frei Luiz de Santa Tereza, reportaria em ofício à Santa Sé de fins do século XVIII: A civitate Natali, seu non tali (ut attenta ejus ternuitate per jocum dicitur). ${ }^{5} \mathrm{O}$ trocadilho seria a única menção à cidade na passagem dos naturalistas Spix e Martius pelo Nordeste, registrada no seu Reise in Brasilien in den Jahren 1817 bis 1820 (publicado em Munique entre 1823 e 1831): "também as duas províncias setentrionais, Rio Grande do Norte e Ceará, são idênticas nas suas condições físicas à de Pernambuco. A capital da primeira, a cidade de Natal, é a mais insignificante entre as cidades da costa ao norte do Brasil ("Cidade - não há tal', dizem os vizinhos)". 'Sem o tom jocoso, as "Memórias históricas" de Joze Pizarro e Araújo seguiam na mesma trilha, apontando a contradição entre as suas reais condições e o título de cidade outorgado desde a fundação: "a capital d'esta Provincia, bem que se denomine [cidade de] Natal desde 1599, (...), contudo não passa agora de villa florescente". Câmara Cascudo, que compulsou muitos desses relatos, afirma que o motejo perdurou até o final do século XIX.

Mais do que arrolar as descrições de Natal nesses e em outros documentos do período colonial - tarefa já empreendida com maior ou menor propriedade pela memorialística e historiografia locais -, interessa discutir neste capítulo a maneira como esses relatos, narrativas e cartografias foram apropriados e conformaram não só uma história da cidade, mas principalmente um projeto historiográfico que, muitas vezes - quer direta ou indiretamente -, legitimou a República e os intentos de modernização urbana defendidos e promovidos pelas elites políticas e econômicas envolvidas. Isto é, a contraparte desse processo que, no âmbito da história urbanística, tem sido chamado de "desconstrução da cidade colonial". ${ }^{8}$

Desconstrução física - derribando casas, sobrados e quarteirões ditos insalubres, refazendo fachadas, construindo novos prédios ao sabor fin-de-siècle europeu, alargando e retificando ruas ou mesmo destruindo o tecido urbano do período colonial - que, para além dos imperativos e diretrizes técnicas, não pôde se desvencilhar do conjunto de formulações do pensamento social e histórico no Brasil da virada para o século XX. ${ }^{9}$ Não se destruíam apenas as pedras, as paredes, os elementos materiais que tornavam visível essa cidade, mas principalmente o conjunto de significados, negativos sobretudo, que parecia encerrar. Atraso, ignorância, indolência, insalubridade, falta de ordem, erros de fundação e localização, desleixo na construção de ruas e cidades, foram algumas das palavras e temas mobilizados para compor uma interpretação recorrente nos vários discursos sobre o espaço colonial que se tornaria hegemônica. ${ }^{10}$

Freqüentemente em negativo, a representação desse espaço na construção do passado foi parte integrante e fundamental, como se pretende discutir a partir do caso de Natal, do processo de modernização urbana empreendido no início do século XX. Já se afirmou o lugar que as formas de representação da cidade ocupam nas políticas e nas práticas de intervenção urbanas, como os saberes constituídos formam constructos intelectuais que

\footnotetext{
5 Tradução do Cônego Estevam Dantas: "Da cidade do Natal, ou não tal, como em vista do seu tamanho por graça se diz" (apud Cascudo, 1942, nota 12 ao cap. V, p.116).

${ }^{6}$ Spix e Martius, 1938, vol. 2, p.270; grifo nosso.

7 Araújo, 1822, p.147.

8 utilizamos essa expressão no sentido empregado, por exemplo, no texto introdutório da coletânea "Urbanismo no Brasil" (Leme, 1999) ou no artigo de Ana Fernandes e Marco Aurélio Gomes (1991) que discute a construção do campo temático da história urbana no Brasil.

9 É sabido, como discute José Lira (1999), que o saber urbanístico no Brasil seria atravessado, em especial entre as décadas 1920 e 1940, pelas mais várias hipóteses de formação do Brasil; Cândido Campos (2000), de forma similar, aponta como a introdução do urbanismo no Brasil foi enredado no debate brasileiro acerca da construção da nação e da sua nacionalidade.

${ }^{10}$ A brasilianista Roberta Delson (1979) revela, por exemplo, no início dos seus estudos sobre a criação de vilas e cidades no Brasil do século XVIII, a sua surpresa ao se deparar com a representação - a qual chamará de "mito" - quase axiomática nos estudos sobre a América Latina, da cidade colonial desordenada e da falta de planejamento português no Brasil. Antes ainda, em estudo publicado inicialmente em 1968, Nestor Goulart (Reis, 2000a, 2000b) já chamara a atenção, a partir de vasta pesquisa documental, para a existência de planos urbanísticos no Brasil desde o século XVI e a sua relação com os interesses da metrópole sobre a colônia.
} 
ajudam a delimitar campos conceituais que orientam a observação e a avaliação da própria cidade; ${ }^{11}$ ou mesmo o lugar das palavras e dos nomes na construção da realidade social e do discurso na formação do objeto sobre o qual se debruça. ${ }^{12}$

Aqui, importa deslindar especificamente uma certa interpretação na leitura da história da cidade que seria tema recorrente, ou melhor, substrato de várias representações que moveram discursos e justificativas no processo de modernização urbana de Natal. Interpretação que, embebida na série de registros dos viajantes europeus e mobilizando leituras cientificistas, deterministas e evolucionistas, procedimentos sociológicos, geográficos e históricos ou mesmo forjando mitos fundacionais, seria retomada e atualizada na década de 1920 e culminaria na construção hegemônica de sua história, cujo principal artífice foi Luis da Câmara Cascudo.

Além do vínculo e retomada, numa perspectiva crítica, da tradição intelectual local, em especial as representações de cidade e tentativas de análises históricas de Henrique Castriciano, Eloy de Souza, Manoel Dantas e Tavares de Lyra, e da pesquisa direta em documentos do período colonial (relatos de viajantes, atas do senado da câmara, cartas de aforamento, etc.) este processo seria perpassado, em Cascudo, pelas lides do modernismo e do regionalismo, pelo diálogo franco com Mário de Andrade, pelo olhar de um etnógrafo em formação, pela sua escrita ensaística, pelo elemento criativo e literário que é indissociável da sua obra, na qual a tradição oral popular ganhou uma significância que a equiparava aos fatos e registros oficiais que caracterizam a história tradicional. ${ }^{13}$ Os contos e ditos fantásticos passaram, então, a fazer parte da história da cidade, do seu povo, do seu ethos, assim como os elementos da cultura material e não-material da região e do país, dentro de uma perspectiva universalista, como o demonstram as suas obras da fase mais madura; dentre elas, o "Rede de Dormir" (1959), cuja epígrafe de Bruno Schier é um exemplo: faria a história a partir de tudo aquilo que pertence, exprime e define a presença humana, como a jangada, os gestos, a alimentação, a literatura oral, a rede de dormir. ${ }^{14}$

Contudo, antes de se analisar a leitura e contribuição - em formação nos anos 1920 de Cascudo, cabe acompanhar e discutir os textos que lhe antecederam e ajudaram a forjar a interpretação-chave à elaboração da história de Natal. Relacionados cronologicamente aos ciclos mais intensos de modernização urbana, a tessitura desses textos, todavia, afasta-se daquele tipo apologético, oficial ou oficioso de artigos e matérias, de relatórios técnicos e mensagens de governo. É certo que, ao expressar certos ideais de modernidade e civilidade, não escaparam às injunções e elaborações de época acerca dos significados da cidade moderna. Entretanto, vê-los apenas como justificativas aos interesses das elites nos projetos de reforma urbana, além de ser uma interpretação simplista ou mesmo errônea, desconsidera-os per se e obscurece os valores, os signos, as palavras, os fatos, as interpretações mobilizadas que ajudam a entender os sentimentos de uma época. ${ }^{15}$

O que interessa é exatamente o fio condutor que está na raiz desses textos e de sua interpretação, isto é, o tema da construção da cidade moderna, que, conformando uma tese central a este capítulo, pressupôs uma dupla operação: tanto a transformação física da cidade quanto a construção imagética e historiográfica da cidade sobre a qual se intervinha e se

${ }^{11}$ Cf. Bresciani, 1998, p.242.

${ }^{12}$ Cf. Pechman, 1998, e Pesavento, 1998; a coletânea organizada por Bresciani (2001) põe em questão as "palavras da cidade", seus conteúdos, significados, deslizamentos semânticos e imbricações nos processos sociais de urbanização.

13 História tradicional no sentido empregado por Burke (1990; 1992).

${ }^{14}$ Cf. Araújo, H. H., 1998, p.61,69; Andrade, M. O., 1999; a citação é: “Temos de nos habituar a considerar como fontes de história os mesmo fenômenos cotidianos de nossa vida popular, cujo valor testemunhal de modo algum é inferior às crônicas e documentos antigos. Da ornamentação de um pórtico e de um instrumento agrícola, da forma de uma casa e boina de uma mulher, pode-se haurir mais informação da História da Civilização que de muitos molhos de atas dos nossos arquivos" (Bruno Schier, Aufbau der Deutschen Volkskultur, p.334, apud Cascudo, 1959, p.09).

${ }^{15}$ Como vários desses textos se aproximam de um formato literário, podemos concordar com Keith Thomas (1983, p.19) quando afirma que a literatura, embora deficiente como fonte histórica, é insuperável como "guia para os sentimentos e idéias pelo menos dos setores mais articulados da população". 
idealizavam e operavam reformas urbanas e planos gerais. Isto é, pari passu à "desconstrução da cidade colonial", à construção física, material, da cidade moderna e à assunção de seus símbolos e valores, a construção historiográfica da (imagem da) cidade colonial.

Processo no qual a apropriação dos relatos dos viajantes dos períodos colonial e imperial foi fundamental. Mesmo ao longo do século XIX o Novo Mundo apareceu recorrentemente, no imaginário europeu, como uma "terra mal emersa da criação", em que havia o predomínio da natureza sobre a sociedade e cujo tempo histórico era sempre o devir. ${ }^{16}$ E essa condição de vir-a-ser, aliado à problematização da questão racial, esteve na base da construção da história (oficial) da nação. ${ }^{17}$ Futuro posto em formulação e, no esteio de leituras cientificistas, em construção, principalmente a partir da chamada "geração de 1870", formada pelos "homens de sciencia", bacharéis, médicos, cientistas e, depois, também engenheiros, que arrogariam para si o papel principal na transformação do país em uma nação civilizada e moderna. ${ }^{18}$

Em Natal essa formulação e construção seriam feitas a partir da constatação de uma ausência, do vazio, da inexistência de uma cidade que era apenas um predicamento pelo que viria a ser no futuro, como afirmou Koster, mas que não existia de fato. "Cidade apenas no nome" ou uma "massa esperando aspecto", diria Cascudo em fins da década de 1920. ${ }^{19}$ A condição de cidade instituída desde a sua fundação (sem ascender na hierarquia de importância dos aglomerados urbanos coloniais: arraial-freguesia-vila-cidade), ${ }^{20}$ embora até o início do século XX não condizente com o título de nascença, colocava diversos problemas aos intelectuais que tentavam pensar a história da cidade e a sua incipiente transformação que vivenciavam e da qual eram partícipes. Quer apontando o erro fundacional dos portugueses, o que explicaria o seu atraso e a psicologia de seus habitantes, estabelecendo a crítica à colonização portuguesa e o elogio da civilização holandesa, constituindo um mito de origem que tornava plausível a construção da Natal moderna, ou as bases sistemáticas de uma historiografia local, o novo regime político apareceria, para a elite local - intelectual sobremaneira, ${ }^{21}$ como o momento de tornar presente esse futuro, de dar aspecto a uma massa indistinta, de dar substância ao nome.

\section{9-1889: a ausência de uma cidade}

Se há o registro de alguns textos de cunho historiográfico e/ou memorialístico, desde o último quartel do século XIX, como o "Breve notícia da província do Rio Grande do Norte" (1877) de Manoel Ferreira Nobre ou o ensaio "Homens de Outr'ora" (1898) de Manoel Dantas, além de referências esparsas em alguns artigos ou trechos de mensagens oficiais, não obstante a consulta ao conjunto de fontes desse período faz supor que essa produção era pouco significativa tanto em volume como em qualidade. ${ }^{22} \mathrm{O}$ esforço pela construção mais sistemática e consistente de uma história local apareceria no início do século XX, vinculado à criação do Instituto Histórico e Geográfico do estado.

\footnotetext{
${ }_{16}$ Mori, 1999; vale lembrar que para o naturalista alemão Alexander von Humboldt, cuja obra - e em especial Ansichten der Natur (1808) - teve grande influência sobre o pensamento científico oitocentista e sobre os viajantes-cientistas que se arvoraram aos trópicos, a História do Homem era dependente da aparência exterior da Natureza, do contorno do montes, da fisionomia de animais e plantas, do azul do céu, da forma das nuvens, da transparência atmosférica, etc. (Cf. Belluzzo, 1999, v. 2, p.23-24).

17 O ensaio do naturalista Von Martius sobre "como escrever a história do Brasil”, publicado na Revista do IHGB em 1844, falava no Brasil como um "país que tanto promete", cujas bases assentavam-se em suas três raças formativas (Cf. Schwarcz, 1993, p.111-113).

${ }_{18}$ Cf. Sevcenko, 1983; Ventura, 1991; Schwarcz, 1993; Herschmann e Pereira (orgs.), 1994.

${ }^{19}$ Cascudo, 1929b, 1929c.

${ }^{20}$ Cf. Marx, M., 1991.

${ }^{21}$ Embora pareça ocioso afirmar, não se pode deixar de mencionar que os nomes da elite intelectual, em sua maioria, estavam estreitamente vinculados, quando não se confundiam, aos nomes dos grupos dominantes política e economicamente.

${ }^{22}$ Cf. na bibliografia o conjunto de documentos e acervos consultados para esta pesquisa.
} 
Fundado em 1902, sob os auspícios da primeira administração do governador Alberto Maranhão, o IHGRN não se afastaria do padrão dos seus pares nacionais estabelecidos ainda no Império. Caracterizavam-se mais como "sociedades de corte" do que como agremiações intelectuais e por produzir um saber de cunho oficial que ajudava a recriar o passado e a solidificar mitos de fundação. Subvencionados diretamente pelo estado, legitimavam as elites locais e escreviam uma história eminentemente regional. ${ }^{23}$

Embora não seja o interesse deste trabalho discutir a especificidade da composição social e da produção historiográfica do IHGRN - o que exigiria, de início, uma pesquisa acurada em sua revista ${ }^{24}$, não se pode esquecer o papel que a instituição desempenharia na organização de um importante acervo ou na inserção de diversos intelectuais, empenhados na construção da história de Natal como cidade, no seu quadro de sócios. Congregando documentos raros, coleções particulares e oficiais, cartapácios do período colonial, relatos de viajantes, permitiu a elaboração de estudos mais fundamentados, como o "Índios célebres do Rio Grande do Norte" de Luiz Fernandes. Ademais, era um centro de discussão intelectual que, bem ou mal, reverberava temas candentes colocados nacionalmente.

É dentro desse espírito de época que se pode compreender a série de nove artigos que Henrique Castriciano ${ }^{25}$ dedicou ao poeta popular Lourival Açucena por ocasião do seu falecimento. Publicados originalmente no jornal A República entre julho e agosto de 1907, seriam reeditados nas décadas de 1930 e 1960 - aqui na forma de livro organizado por Cascudo e intitulado "Nosso amigo Castriciano". 26

Nascido em 1827, Lourival Açucena, o trovador do "bom humor grosseiro" herdado da "velha chalaçaria portuguesa", aparece para Castriciano como um mote para pensar e discutir a cidade. Era antes de tudo um "typo representativo" da Natal antiga e o seu falecimento representava o fim de um período de uma cidade ainda em transição no início do século XX. ${ }^{27}$ Eivado numa leitura determinista que em vários momentos parece estar se remetendo a "Os Sertões" de Euclydes da Cunha, ${ }^{28}$ não é a qualidade da poesia de Lourival que interessa, salvo quando denuncia ou revela traços atávicos, matrizes formadoras do tipo local ou nacional. De fato, um esboço de crítica literária que, tributária das formulações da chamada "Escola do Recife" e, em especial, de Silvio Romero, tomaria as noções de raça e natureza como fundamentos científicos para entender a formação de uma literatura e de um estilo originais sob os trópicos. ${ }^{29}$

Assim, não surpreende que os três primeiros artigos fossem destinados à descrição do meio físico, da cidade "que serviu de berço à curiosa figura literária" que Castriciano se propunha a estudar. Natal era descrita como um arremedo de cidade que os melhoramentos empreendidos dentro do regime republicano pouco puderam fazer para mudar-lhe as características. $^{30}$

\footnotetext{
${ }^{23}$ Mesmo no caso do IHGB, sediado no Rio de Janeiro; cf. Schwarcz, 1993, p.99-140.

${ }^{24}$ Publicada desde 1903 com periodicidade irregular, permitiu a divulgação de documentos inéditos, além das atas de reunião e da produção de seus sócios.

${ }^{25}$ Nascido em Macaíba-RN em 1871 e educado no Recife, Castriciano, poeta simbolista de muita influência nos círculos intelectuais locais, ocupou diversos cargos públicos; foi secretário de governo de Tavares de Lyra em 1904, procurador-geral e secretário de estado de Alberto Maranhão entre 1908 e 1913 e vice-governador entre 1914 e 1924; foi co-fundador da Liga de Ensino e organizador da campanha pela instrução pública das classes populares e, sobretudo, das mulheres; esteve à frente da criação da Escola Doméstica em Natal, em 1911. Faleceu em Natal em 1947 (Cf. Oliveira, G. P., 2000; Araújo, H. H., 1995; Cascudo, 1921; 1965).

26 As referências ao texto de Castriciano que se seguem baseiam-se na transcrição dos noves artigos publicados no livro organizado por Câmara Cascudo (1965, p.189-216).

27 Castriciano, 1907, partes II e VII.

${ }^{28}$ Ibidem, parte I; o grande sucesso editorial e a rápida difusão já a partir da primeira edição d' "Os Sertões” (Ventura, 2000), ajudam a explica a força de um estilo e de uma narrativa presente, por exemplo, nesses artigos de Castriciano.

${ }^{29}$ Cf. Ventura, 1991.

${ }^{30}$ Castriciano, 1907, parte II.
} 
Resultado do "erro dos que a fundaram", a cidade permaneceu enquistada por três séculos entre o rio, as dunas e o oceano. "Ella devia estar na outra margem ou, por exemplo, em Guarapes", onde, devido a menor largura do rio Potengi, facilmente se construiria uma ponte que permitisse o acesso ao sertão da pecuária e produtor de algodão. Isolada, "sem communicação fácil para o interior", sem comércio, indústria, recursos próprios ou movimento, escravizada cultural e comercialmente à capital pernambucana, "Natal ficou sendo uma cidade curiosa, mixto singular de bucolismo e de civilização em esboço". ${ }^{31}$

Mais ainda, o meio físico - "a topographia da capital, a paysagem doce e aspera ao mesmo tempo, a vizinhança do mar, a brutalidade do nordeste" - e social determinara o comportamento psicológico do natalense comum, fruto do isolamento e, por conseguinte, do atraso. Eram, como exemplificava ordinariamente o poeta Lourival, assimiladores, bastante indolentes e um pouco sensuais, ignorantes (da vida moderna nos grandes centros), céticos e incapazes de profundas afeições ou de ódios acirrados. ${ }^{32}$

Tentando estabelecer a especificidade local, Castriciano evocava no entanto uma série de representações comuns acerca do povo e do que seria a raça brasileira. Por outro lado, se o clima e o meio influíam negativamente na formação do indivíduo, esses determinantes não lhe apareciam irreversíveis ou inconciliáveis. Intelectual filho do "século da ciência", da fé no poder transformador do progresso, Castriciano vislumbrava nas transformações materiais do meio físico a possibilidade de superação do atraso e do atavismo psicológico do natalense. Mesmo dentro de modelos hierárquicos, normativos e eurocêntricos, desvencilhava-se assim do viés condenatório de alguns autores que tiveram influência no meio intelectual brasileiro, como Buffon ou Cornelius de Pauw, para quem a "ação depravadora" dos trópicos atravancaria o progresso e a superação do estado selvagem. ${ }^{33}$

Se a saída para o impasse, como se afigurava a possibilidade de progresso nos trópicos, poderia ser entrevista na transformação do meio físico, ela era resumida e sintetizada no tema da superação do isolamento não apenas geográfico, mas principalmente e em conseqüência, social, cultural, psicológico.

A facilidade de locomoção, de circulação (de idéias e mercadorias), o rápido intercâmbio entre as pessoas, o acesso aos periódicos das cidades maiores e aos livros (relativamente) recém-publicados no Brasil e no exterior apareciam para Castriciano como condições essenciais para efetivar tal passo, para civilizar-se enfim, como testemunhavam os jovens de sua própria geração. "Sacudir de um momento para o outro a poeira do tempo, colher impressões novas, tomar passagens a bordo ou no trem, viajar, educar o espírito e a retina" deixara de ser algo extraordinário, pelo menos para os mais abastados. Ao contrário daqueles nascidos antes de 1850, para os quais uma viagem a Recife "constituía grande acontecimento na existência do indivíduo", um verdadeiro regalo. ${ }^{34}$

Os artigos seguintes - partes IV a VIII - dedicavam-se a entender o poeta Lourival e sua inserção no meio físico e social de Natal. Ascendência, descrição física, modo de falar e andar, predicados intelectuais, influências e interesses artísticos, posicionamento político, leituras e autores favoritos, hábitos, desventuras na boemia, a minudência do relato de Castriciano procurava fixar a expressão viva de um tipo, demonstrar como a individualidade conformava-se, constrangia-se, restringia-se aos condicionantes do meio.

Aluno inteligente, de "assombrosa memória", Lourival tivera a oportunidade de estudar francês, latim, filosofia, retórica, música; conhecia de sobejo história antiga, as tragédias gregas e "Os Lusíadas". Contudo, em meio ao "retardado sentir natalense" não pôde

\footnotetext{
31 Ibidem, parte I.

32 Ibidem

33 A visão dos trópicos no pensamento europeu e a influência dessa leitura na formação da crítica literária no Brasil são discutidas por Roberto Ventura (1991).

${ }^{34}$ Castriciano, 1907, parte III.
} 
acompanhar a "evolução da intelectualidade brasileira". Assim, sua produção poética também se ressentia na modorra local. Os vôos curtos de sua musa continuavam com uma "insuportável feição arcádica" mesmo no auge do romantismo no Brasil. ${ }^{35}$

Se possuía versos tão datados ou mesmo sem qualidade artística, o que explicaria a persistência da fama do poeta popular por tantos anos, até o início do século XX? A razão, insistia Castriciano, estava no meio isolado fisicamente e, por conseguinte, atrasado social e culturalmente. ${ }^{36}$

\begin{abstract}
"E só descendo a chronica local se pode compreender essa singular organização de bohemio, retardatário no meio da evolução litteraria do paiz, não por incapacidade, mas pelas exigências do meto que elle, na qualidade de legitimo gosador, nunca procurou contrariar e sim interpretar. Nem Gregorio de Mattos, nem Maciel Monteiro. Faltou-lhe a mordacidade de um, a placidez do outro e o ambiente intellectual em que os dous se formaram". ${ }^{37}$
\end{abstract}

Enquanto a Corte e diversas outras províncias tinham evoluído ao longo do século XIX, Natal não recebera nenhum quinhão desse progresso. Estava presa ainda aquela vida acanhada, mesquinha, embora simples, ingênua, natural, que marcara a vida no Brasil colônia, para a qual Lourival era, mais do que um tipo, um símbolo. ${ }^{38}$ Símbolo do período em que "a área da cidade mais ou menos decentemente construída era insignificante; havia grande número de palhoças e entre os dois bairros estendiam-se muitos metros de terreno desocupado, predispondo os moradores de uma outra parte ao retraimento que o tempo mudou em rivalidade". ${ }^{39}$

Símbolo persistente que parecia ser a um só tempo matéria curiosa, de assombro, espanto e, principalmente, de incômodo. Assombrava porque, como um elemento pitoresco, encarnava "o espírito alegre da antiga sociedade natalense" ainda no início do novo século; incomodava porque lembrava as conseqüências e os significados da permanência dos elementos do isolamento da cidade, apesar do advento do novo regime e do século XX. Nas palavras de Castriciano,

\footnotetext{
"A Republica como que reformou a capital; esta alargou-se, estendeu-se, porém os melhoramentos não alteraram a sua physionomia de aldeia.

Esta só poderá ser modificada quando tivermos o commercio que nos trará a communicação por via férrea do centro; movimento marítimo capaz de nos interessar pela causa do exterior; prompta circulação urbana e o accrescimo da fortuna particular de modo a permitir a construcção de prédios de architectura moderna; os elementos enfim que em toda parte concorrem para o progresso e para a civilização.

Contudo, o jardim [Augusto Severo], o theatro [Carlos Gomes], o calçamento e o nivelamento de certas ruas, especialmente da Avenida Rio Branco, deram-nos um ar mais distincto embora o conjuncto da cidade, desde as casas mal construídas até o
}

\footnotetext{
${ }^{35}$ Ibidem, parte IV; embora não seja nosso interesse discutir o mérito literário da obra de Lourival, cabe lembrar que a crítica de Castriciano não ilumina o vínculo do versejar popular e sertanejo de Lourival à tradição ibérica, expresso na métrica de "quadras", "parcelas" de cinco sílabas e nove pés, martelos, etc. (sobre os modelos de versos sertanejos Cf. Cascudo, 1939, p.15-19 et seq.), como pode ser percebido em alguns dos poucos versos transcritos por Castriciano.

36 Ibidem, parte IV.

37 Ibidem, parte VIII.

38 Ibidem, parte VII e VIII; o sentimento "nativista", que marcara as discussões dos vários grupos políticos e intelectuais locais desde o final do Império, continuou na crítica ao tipo de "federalismo" - acusado de olhar com desdém para as antigas províncias do Norte - da Primeira República (Cf. Bueno, 2002).

${ }^{39} \mathrm{Ibidem}$, parte II; embora não nomeie, Castriciano aqui se refere claramente às disputas entre xarias e canguleiros.
} 
aspecto dos habitantes deva impressionar pouco satisfatoriamente o viajante que notará logo a nossa curiosidade matuta". ${ }^{40}$

Inescapável e eloqüente conclusão a que esse intelectual e homem de governo fez chegar. Interessado havia muito nas "causas retardatárias do nosso progresso", ${ }^{41}$ Castriciano não se iludia, ou melhor, contentava com as reformas urbanas empreendidas até 1907. Sem atacar decisivamente as questões que se lhe afiguravam essenciais, Natal mantinha ainda a sua acanhada "physionomia de aldeia", permanecia como um arremedo de cidade; condição que exacerbava o sentimento de atraso em relação ao que se considerava "civilizado".

Propondo estabelecer uma crítica literária da obra de Lourival, o texto de Castriciano todavia não se demora a pôr em primeiro plano a matéria que lhe subjaz e logo o fundamenta: a relação de determinação entre o meio, as condições sociais e a história. A narrativa sobre o poeta popular ajudava assim a moldar e ilustrar a interpretação sobre as condições do atraso de Natal. Cidade que não era cidade, pouco mais que aldeia, a possibilidade de projeção para o futuro como "capital digna" baseava-se na capacidade de se reverter as condicionantes negativas impostas pelo meio, superando os elementos geográficos e históricos do seu isolamento, pode-se resumir grosso modo a elaboração de Castriciano.

Não se pode deixar de sugerir uma última possibilidade de leitura desses artigos, que aparece em contraponto. A incompletude das reformas empreendidas sob o regime republicano até aquele momento revelava-se, mais do que na persistência da obra de Lourival - que, sem o mesmo "ambiente social" que lhe formara, definhava junto com os costumes, as festas, os eventos nos quais foi pródigo ${ }^{42}$, na insatisfação das elites republicanas, que se manifestava em textos como esse de Castriciano. Em transição, Natal não era mais a "aldeia" bucólica e cediça da geração do velho poeta, mas também não era (ainda) a cidade almejada pelo projeto modernizador dessas elites.

Em fevereiro de 1909, Eloy de Souza ${ }^{43}$ abriria a série de conferências programadas para o salão de honra do palácio do governo, durante a segunda administração de Alberto Maranhão, retomando o tema da cidade em transição e exacerbando o sentimento de incômodo frente aos costumes ainda não assentados à nova realidade urbana - que se ansiava transformar. Em suas palavras, “...de cinco anos a esta parte, Natal perdeu por assim dizer, repentinamente, costumes que pareciam inveterados, não encontrando, entretanto, sucedâneos em harmonia com as necessidades espirituais de seu tempo".

Incômodo que se traduzia em descompasso, revelando assim a chave de leitura de sua narrativa, o que permite compreender o itinerário que percorre para chegar a "uma época de hábitos que, apesar de nos serem mais próximos, parecem, entretanto, afastados e remotos, como se os víssemos através de um binóculo invertido". ${ }^{45}$ Que hábitos eram esses, cuja distância - social, cultural e temporal - demarcava claramente?

Não os daqueles que habitavam as terras ainda por descobrir ou mesmo daqueles que a conquistaram e defenderam - advertia Souza a sua platéia -, mas "dos que fizeram a cidade, semearam os povoados, plantaram as fazendas, situaram e moveram os primeiro engenhos"; isto é, daquela população, urbana e rural, que se assentou e se consolidou ao longo do século XVIII na cidade de Natal. Costumes moldados em uma vida social sem atrativos, em um

\footnotetext{
40 Ibidem

${ }^{41}$ Causas que já se esforçara por identificar no seu relatório de secretário do governo de 1904, importante documento que dá conta das ações governamentais tomadas por ocasião da grande seca desse mesmo ano (Cf. Idem, 1904).

42 Castriciano, 1907, parte VII.

43 Irmão de Henrique Castriciano, Souza nasceu em Recife, em 1873; bacharelou-se em Ciências Sociais e Jurídicas na Faculdade de Recife, em 1894; foi deputado federal (de 1897 a 1914 e de 1927 a 1930) e senador da República (de 1915 a 1927 e de 1934 a 1942) pelo Rio Grande do Norte; faleceu em Natal em 1959 (Cf. Cardoso, R., 1999, p.47-60).

${ }^{44}$ Souza, E., 1909, p.40.

45 Ibidem, p.31.
} 
espaço urbano precário, "com a sua igreja, a cadeia, a forca, o pelourinho, a casa da câmara e as moradas esparsas pelo areal dos dois bairros, entaipadas umas, outras, e eram o maior número, tecidas de ramos e cobertas com as folhas das diferentes palmeiras indígenas", tudo isso contribuía para compor um quadro de estagnação e atraso. ${ }^{46}$

\begin{abstract}
"Dois séculos após a fundação da cidade e criação da capitania, ainda vivíamos quase tão primitivamente como os naturais, contra os quais havíamos cruamente pelejado, e, por ventura, nos encontrávamos em atraso maior e pobreza mais generalizada do que ao tempo da ocupação holandesa, quando se construíram os primeiros engenhos de açúcar, e a vida agrícola atravessou uma fase de atividade desconhecida". ${ }^{47}$
\end{abstract}

Dando vazão a uma representação que se tornava recorrente acerca da presença holandesa no nordeste no século XVII, Souza lamentava que, ao contrário do Recife, nada houvesse restado (ou sido realizado), material e culturalmente, da obra civilizatória da administração de Maurício de Nassau em Natal. Ao invés da herança da suposta modernidade da experiência batava nos trópicos, o retorno "ao nosso lamentável estado de indolência anterior". ${ }^{48}$

Ecos do período de contestação ideológica ao Império brasileiro que, em conseqüência, condenou também o passado e as heranças da colonização portuguesa. A rejeição ao passado lusitano estava contida implicitamente em muitas das formulações - quer envolvidas no evolucionismo, no "germanismo da Escola do Recife", no republicanismo e/ou no abolicionismo - daqueles que compuseram o ambiente intelectual brasileiro fin-de-siècle. $\mathrm{O}$ obscurantismo na relação entre o poder temporal e o espiritual, a monarquia que pervertera a vida política, o monopólio comercial que segregara o Brasil do mundo, o trabalho servil que viciara a sociedade e a indispusera para a civilização e a miscigenação que comprometera a possibilidade de futuro do país compunham um conjunto de tópicos de crítica ao passado colonial - e imperial, do qual também se nutriu a nostalgia do Brasil holandês e o seu movimento de revalorização historiográfica. ${ }^{49}$

É certo que essas críticas logo atingiram as reflexões sobre as cidades e sobre o processo de modernização do início do século XX. No Recife, em especial, o período holandês fundamentaria um "mito de origem" que opunha a urbanização da ilha de Antônio Vaz - o plano original da Cidade Maurícia - ao não-urbanismo português, cujo tecido remanescente - representado por ruas e edifícios insalubres, escuros, abafados, irregulares testemunhava a decadência do passado colonial. As necessidades de reformas urbanas modernizadoras formuladas no discurso das elites encontravam assim uma justificativa que era inscrita na história da cidade. Uma vocação original para a regularidade e a racionalidade construtivas, para a domesticação da natureza, para o planejamento da cidade, que, projetando-se por sobre os séculos e destruindo a herança urbana portuguesa, unia a construção da cidade moderna à "idade de ouro" da cidade civilizada de Mauriţstadt. ${ }^{50}$

Sem vestígios materiais da ocupação holandesa em Natal que permitisse uma recriação historiográfica por este viés, Eloy de Souza não desenvolve o tema e se restringe ao lamento de fundo nostálgico com o qual certamente travara contato no Recife. É importante observar que essa idealização do passado seria logo substituída na historiografia local por uma visão crítica e negativa da administração batava. Se Tavares de Lyra já apontara a impossibilidade de se falar em um empreendimento civilizador e urbanizador para o território

\footnotetext{
46 Ibidem, p.08-11.

${ }^{47}$ Ibidem, p.13.

48 Ibidem

${ }^{49}$ Mello, E., 1986 (em especial os capítulos 8, "Nostalgia nassoviana”, e 9, "Olinda ou Olanda").

${ }^{50}$ Cf. Lira, J. T. C., 1996, p. 212-225.
} 
do que seria depois o Rio Grande do Norte, Rocha Pombo e, principalmente, Câmara Cascudo enfatizariam a ação deletéria que teria depauperado e atrasado ainda mais a região e, especificamente, Natal. ${ }^{51}$

Para Souza, os hábitos que pareciam tão distantes - embora tão próximos, reconhece - no tempo e no espaço também não eram decerto aqueles forjados no ambiente sertanejo, em especial da região do Seridó, para o qual tece um longo e respeitoso elogio. Lugar de homens de "espírito prático", de "elementos étnicos mais aptos", o sertão era representado como fonte de reserva moral e física da nação. ${ }^{52} \mathrm{O}$ elogio à esfera privada do espaço senhorial, patriarcal, tutelado, da casa sertaneja e da casa-grande não desvirtua todavia as suas considerações sobre a cidade; o que desmonta, desde logo, uma leitura apressada que o vincule estritamente às tendências agraristas, anti-urbanas, de parte do pensamento social brasileiro para as quais a cidade era um espaço de decadência.

De certo modo, o elogio de Eloy de Souza ao sertão pode ser aproximado àquelas manifestações tradicionalistas de valorização do nordeste que, depois, na década de 1920, fariam parte do movimento regionalista; conscientes da decadência da região, apontavam para a construção nostálgica do seu "passado glorioso". ${ }^{53}$ Não por acaso, Souza foi um dos colaboradores do Rio Grande do Norte, ao lado do seu irmão Henrique Castriciano, do "Livro do Nordeste", com um artigo sobre os cantadores da região. ${ }^{54}$ Atitude que não era nova, tendo em vista a ação de ambos em promover aspectos da cultura regional - a culinária e os desafios dos cantadores e violeiros, por exemplo - nos eventos oficiais de recepção a visitantes ilustres desde o início do século XX. ${ }^{55}$

Entretanto, esse movimento de valorização não correspondia a uma defesa do espaço tradicional da cidade. Ao contrário, a "agonia do velho Natal" era saudada com impaciência e regozijo:

\begin{abstract}
"Natal, minha senhoras e meus senhores, se transforma e sente-se que aos poucos irá deixando essa amarga tristeza que ainda lhe dá um aspecto soturno e mau. [...]. A cidade desperta do seu sono três vezes secular e eu sinto bem a alegria de ver que a estão vestindo de novo, para alegria de uma vida nova. [....]. O mesmo esforço que tem rasgado avenidas empedra o areal, ameniza as ladeiras, saneia as terras alagadas. Começou a viação urbana e o bonde cimentará de vez a obra de pacificação entre os dois bairros. [...]. Tudo mudado. Metade uma geração levou para a sepultura costumes simples, tradições ingênuas, hábitos pitorescos, e alguma coisa que por ventura reste desse passado irá antes de nós ou irá conosco na voragem do tempo, na pressa do progresso impaciente". ${ }^{56}$
\end{abstract}

Frente à força do tempo e às promessas do progresso, não havia espaço para nostalgias, remorsos ou restrições. Não importava a "mutilação da paisagem do sertão" pelas estradas de ferro e de automóveis ou pelas barragens e açudes, se isso significasse minorar o sofrimento das secas; nem a perda das "tradições ingênuas", das peixadas ao luar, das "cavalhadas bizarras", das romarias fluviais, dos passeios aos arrabaldes, se isso significasse

\footnotetext{
51 Cf. Tavares de Lyra, 1921; Pombo, 1922; Cascudo, 1924, 1926, 1947; o primeiro escrito de Câmara Cascudo serve-nos de exemplo para ilustrar essa visão crítica: "O Rio Grande do Norte, jugulado sob a manopla ferrea do batavo, gemeu 21 annos. As privações e os massacres estão no domínio da História. A obra material foi nulla e insignificante. [...]. A missão civilizadora de Nassau não chegou aqui, apezar da sua visita" (Cascudo, 1924, p.51-52).

52 Souza, E., 1909., p.15-31.

53 Cf. Azevedo, N. P., 1984.

${ }^{54}$ Editado pelo Diário de Pernambuco em comemoração ao seu primeiro centenário, o "Livro do Nordeste" foi organizado por Gilberto Freyre e publicado em 1925, com a colaboração de diversos intelectuais e artistas da região.

55 Cf. Araújo, H. H., 1995, p. 22-23; a conferência de 1909, que ora comentamos, já trazia a primeiro plano a figura dos "afamados cantadores, boêmios incorrigíveis, vagabundos notâmbulos", como Manoel do Riachão, Manoel Tavares e o exescravo e rabequista Fabião das Queimadas (Cf. Souza, E., 1909, p. 26-27).

56 Souza, E., 1909, p. 44-45.
} 
uma cidade adequada às "necessidades espirituais" - e aos imperativos econômicos - dos novos tempos. ${ }^{57} \mathrm{Em}$ meio ao conjunto de influências teóricas que podem ser desveladas ao longo da conferência, há pelo menos duas outras observações que devem ser feitas sobre o conjunto de considerações que Eloy de Souza estabelece para falar dos "costumes locais".

Antes de mais nada, deve se chamar a atenção para este que é possivelmente o primeiro registro de uma interpretação que se tornaria chave à historiografia local: a cidade, depois de um "sono" trissecular, assumiria finalmente, em princípios do século XX, a sua condição outorgada desde a fundação. Estabelecia assim um vínculo entre o "projeto" modernizador das elites republicanas no estado e um suposto destino histórico inscrito nas suas origens - um mito de fundação - que teria várias e diversas implicações ulteriores. Em 1911, por exemplo, Tavares de Lyra, em um livro de divulgação sobre o Rio Grande do Norte - uma espécie de mensagem de governo para-oficial -, exporia claramente essa relação, inscrito no sentimento comum a muitos de entusiasmo com a República e com as transformações engendradas no contexto do novo regime:

\begin{abstract}
"Natal, que tem mais de tres séculos, era, não ha mais de vinte annos, uma pequena cidade atrazada, sem hygiene, sem conforto, sem movimento, sem vida, apesar de sua excepcional posição topographica. A população era de cerca de dez mil almas e a casaria, formando ruas em sua maioria estreitas e tortuosas, das quaes apenas algumas tinham calcamento e illuminação a kerozene, era baixa, pobre, sem gosto, dando-lhe um aspecto de accentuada decadencia. [...]. A transformação da Capital começou com o novo regimen". ${ }^{58}$
\end{abstract}

A naturalidade e o entusiasmo com que Eloy de Souza afirmou "tudo mudado" parece exprimir - e esta é a segunda observação que interessa destacar - muito mais a condição do observador do que a realidade sobre a qual se debruçava, ou melhor, para a qual lançava as suas vistas. Não à toa fez uso da imagem do "binóculo invertido": o instrumento do cronista "estrangeiro" que registrava despreocupadamente o pitoresco, o exótico, o alheio; suas lentes revelam o sentimento de descompasso, de não pertencimento, enfatizam a distância dessa elite letrada em relação àqueles costumes, e configuram um olhar "desatento" do mundo em que habitavam - como diria Sérgio Buarque na década de 1930 acerca dos intelectuais republicanos. ${ }^{59}$

Lentes européias, "civilizadas", contemporâneas e expectadoras do "bota-abaixo" realizado no Rio de Janeiro sob a liderança do engenheiro Pereira Passos, para as quais os hábitos populares eram sempre vistos como desregrados, desajustados, incompatíveis; defeituosos até, como Souza referir-se-ia a respeito do descuro das "mais elementares condições de higiene" da maioria dos natalenses, da apatia, da "moleza tropical", da falta de cordialidade, de "polidez e do respeito", quer de crianças, jovens ou adultos. "Em qualquer parte onde vos encontreis [as moças e senhoras da cidade] casualmente reunidas, haverá sempre exata coincidência em notardes os recíprocos defeitos, oriundos desse eterno estar em casa ...". ${ }^{60}$

Para a cidade em transformação, ou mesmo em processo de criação - como se afigura nas representações sobre Natal -, e seus novos (e poucos) espaços e cenários de uma vida pública normatizada, exigiam-se novos modos, novos hábitos, novos comportamentos, distantes dos costumes locais e do ambiente que os forjou. Possibilidade que só se encontraria, preconizava Souza, na organização de um sistema educacional extensivo para homens e

\footnotetext{
57 Ibidem, p.30-46 passim.

58 Tavares de Lyra, 1912, p.417, grifos nossos.

${ }^{59} \mathrm{Na}$ sua crítica destinada diretamente aos intelectuais da Primeira República (Cf. Holanda, 1995, p.159-163 passim).

${ }^{60}$ Souza, E.,1909, p.43.
} 
mulheres, e não na tradição - resquício de um passado que se supunha, ou que se desejava, superado.

Pouco mais de um mês depois, em 21 de março de 1909, Manoel Dantas ${ }^{61}$ daria seqüência ao ciclo de conferências programadas para o salão de honra do palácio do governo estadual com o tema "Natal daqui a cinqüenta annos". Criação literária, misto de ficção científica - no sentido dos textos prospectivos ou dos ensaios utópicos oitocentistas -, humour, crônica jornalística, anseio cosmopolita e libelo progressista, o texto logo se tornaria um "clássico", um parâmetro ao qual, nas décadas seguintes, voltar-se-ia para medir o quanto a cidade tinha - ou não - se modernizado ou para atestar a presciência do conferencista. ${ }^{62}$

Contudo, resumir a importância da conferência a um mero exercício de futurologia acaba por deslocá-la do seu contexto. Ademais, não observa que, assumindo um formato de escrita mais livre, sem as preocupações cientificistas dos textos de cunho etnográfico ou geográfico, ${ }^{63}$ podia exprimir acerba e claramente os desejos, as visões, as figurações do significado de civilização e progresso urbano de pelo menos um dos representantes mais ilustrados e atuantes das elites republicanas locais; isto é, tira-lhe o chão que o torna mais significativo e compreensível.

Se o texto suscita várias possibilidades de discussão, ${ }^{64}$ não parece errôneo afirmar que o fio condutor da sua narrativa se assenta na construção da história da cidade. De fato, a especulação sobre a Natal projetada cinqüenta anos a frente só é possível após esse movimento (em quatro atos): a fundação em um território edênico; o caimento, como nos contos populares e nos textos bíblicos, em conseqüência das "paixões indomáveis", do ódio, da cobiça e da vingança, do sangue derramado e da natureza destruída; o terceiro ato é o da punição e purgação pelo isolamento e pela insignificância; por fim, a permissão divina para retomar o seu desenvolvimento, para modernizar-se e ingressar na modernidade. ${ }^{65}$ Surge et ambula, determina-o. A república era este momento de determinação e refundação da cidade.

Narrativa fabulosa e nebulosa - com referências, amiúde cifradas, à posse inicial do território, à colonização portuguesa, à ocupação holandesa, à Guerra dos Bárbaros, dentre outros temas da história oficial da nação, além dalguns fatos pitorescos do início do século XX - em que a tese sobre a história da cidade ganha uma versão mítica, atemporal, como um conto popular que poderia ser transmitido oralmente. Não obstante as tintas de um enredo fantástico, o substrato é similar aos textos de Henrique Castriciano e de Eloy de Souza.

Homem de muitas leituras, atento às notícias e às transformações que aconteciam no mundo ocidental, ${ }^{66}$ preocupado com questões colocadas nacionalmente - como a difusão da educação -, a cidade que surge em sua conferência é uma reiteração da fé no saber técnicocientífico como uma esfera neutra acima dos conflitos e dramas sociais e nas potencialidades civilizatórias do capitalismo.

\footnotetext{
${ }^{61}$ Manoel Dantas nasceu em uma fazenda da região do Seridó (sertão do RN) em 1867 e formou-se bacharel em Ciências Sociais e Jurídicas pela Faculdade de Direito do Recife em 1890; foi jornalista, advogado, inspetor de instrução pública, (é considerado) precursor de estudos mais sistemáticos sobre a história e a geografia do estado, vice-governador entre 1904 e 1906, e presidente da intendência de Natal em 1924, ano em que faleceu.

${ }^{62}$ Comentando o Plano Geral de Sistematização de Giacomo Palumbo, Câmara Cascudo (1929b) diria: "O prolongamento da [Av.] Sachet aceitou o plano inconsciente e primitivo do começo do xadrez. Manoel Dantas que morou no Natal velho sonhou em 1909 a Ribeira 'enxadrezada".

${ }^{63}$ Como os ensaios "Homens d'outrora" (1898) ou "O problema das secas" (1901) (In Dantas, M., 1941).

${ }^{64}$ Como aponta o ensaio “O mito de fundação de Natal ...”, de Pedro de Lima (2000).

${ }^{6}$ Cf. Dantas, M., 1909, p.24-25; a proposição de uma leitura em quatro atos é de Pedro de Lima (2000, p.25-28), embora devamos ressaltar a dessimetria dessa "peça", quase toda concentrada no quarto e último ato: o "renascimento" da cidade depois de um "sono trissecular".

${ }^{66}$ Vários autores (dentre eles Lima, 2000) comentam, por exemplo, que Manoel Dantas já em junho de 1909 traduziu e publicou, n'A República, um resumo do "manifesto futurista" de Marinetti (divulgado originalmente no Le Figaro, em fevereiro desse mesmo ano).
} 
Dentro dessa perspectiva, por exemplo, o texto de Manoel Dantas vislumbrava a resolução dos problemas sociais seculares presentes na história brasileira, como aqueles evidenciados nos períodos mais graves das secas. A racionalidade do homem moderno, transmudada na figura dos engenheiros das comissões federais e nas grandes obras que cumpririam a promessa sebastianista de transformar o sertão em mar, punha por terra os entraves ao crescimento. "A seca desapareceu, ou por outra, o homem venceu a seca", afirmaria: “... barragens colossais haviam fechado aquelas passagens que se escancaravam como partes de uma grande muralha de resistência violentamente rompida. Formaram-se deste modo quatro lagos artificiais bastante extensos e profundos, cujas águas [...] foram se infiltrando pelas terras, foram se desviando pela irrigação, de maneira a converter quase todo o Seridó num vasto brejal". A pujança econômica do sertão seria parte essencial na consolidação de Natal como centro econômico e político do estado. "Natal alegra-se com estes resultados, porque é o escoadouro dos produtos do sertão" ${ }^{67}$

Todavia, interessava-lhe ainda mais as fantasmagorias e o movimento febril da grande cidade moderna. A Natal que surge da sua narrativa é uma metrópole feérica e industrial onde os ícones da modernidade belle époque cingiam-se aos grandes equipamentos, máquinas, transporte de massa, fulgores de eletricidade; aonde convergiam as artes, os negócios, a arquitetura e também o imenso transatlântico, os aeroplanos e tramways, as longas estradas de ferro do trem transcontinental - anulando distâncias e tempos, diminuindo diferenças e ampliando a percepção do mundo, como num "caleidoscópio monstro"; onde as inovações tecnológicas, o telégrafo, os tubos pneumáticos, o telefone, a "fotografia à distância" - que exibia "as óperas e as outras peças de efeito que a esta mesma hora entusiasmam as casas de espetáculo de Paris, Londres e Nova York" -, os ascensores elétricos, os mostradores e as vitrines, faziam parte do cotidiano de seus habitantes; onde o porto recebia uma população cosmopolita que formiguejava em pandemônio por entre os "guindastes elétricos, restaurantes, cafés-concerto, bares, bazares"; onde a "miríade de lâmpadas elétricas" e de "cores caprichosas" iluminavam "os esplendores e as misérias da civilização"; onde "as torres dos edifícios e as chaminés das usinas parecem braços erguidos para o céu num desafio a forças desconhecidas"; 68 onde o elogio do progresso - e a urbanização sem pudor das dunas, dos fundos de vale, do mangue, das margens do rio e do mar - se fazia ao lado do registro poético da paisagem natural. ${ }^{69}$

O entusiasmo com as possibilidades civilizatórias de uma nova realidade urbana permeia todo o texto, pontuado por certas "palavras-fetiche" - como "moderno" e "Haussmann" - que, mesmo usadas de forma imprecisa e sem referências, ampliavam as fantasias e excitamentos: ${ }^{70}$

\footnotetext{
“(...), a cidade antiga sepultou-se na sombra de uma recordação do passado, para ceder o lugar à Natal moderna, bela e radiante, com suas avenidas, parques e praças, com suas árvores, muitas árvores, sombreando o asfalto e oxigenando o ar. Todos os serviços municipais foram reorganizados. Dinheiro não faltava (...) nas obras de melhoramentos de uma cidade que se destinava a ser uma das maiores metrópoles do Novo Mundo. O Haussmann desse renascimento ...". ${ }^{71}$
}

Para além "da névoa do Sonho [de] uma cidade gigante", ${ }^{72}$ cosmopolita, feérica e industrial, pode-se perceber uma concepção de cidade circunscrita e restrita, cujo acesso e uso

\footnotetext{
${ }^{67}$ Dantas, M., 1909, p.36-37.

68 Ibidem, p.27-37.

${ }^{69}$ Como aponta Lima, P., 2000, p.45-46.

${ }^{70}$ Sevcenko (1992, p.227-231) discute em especial a palavra-fetiche "moderno" no imaginário da metrópole em ebulição que era São Paulo no primeiro pós-guerra.

${ }_{71}^{7}$ Dantas, M., 1909, p.38-39.

${ }^{72}$ Ibidem, p.43.
} 
e ocupação do solo era determinado hierarquicamente. Não à toa figuraria como emblema dessa cidade, num monumento erguido em sua praça central, uma frase - "façam o progresso que eu mantenho a ordem"73 - atribuída ao principal líder republicano no RN, Pedro Velho, para lembrar, pode-se dizer hoje, a face excludente e autoritária e as limitações inerentes à modernização no Brasil. ${ }^{74}$

A descrição de Manoel Dantas da Natal depois de cinqüenta anos cristalizava de fato um processo de segregação sócio-espacial que, no momento de sua conferência, apenas se insinuava. A Cidade Nova, criada havia poucos anos, seria o bairro aristocrático, artístico, do luxo e do bom gosto arquitetônico. A Ribeira consolidar-se-ia como o bairro do "alto comércio, da Bolsa, dos grandes estabelecimentos bancários", com um novo traçado urbano, substituindo a malha do período colonial pelo "xadrez de ruas, praças e avenidas". O Alecrim abrigaria a grande massa de operários, não muito distante do "burgo industrial", que se estenderia em direção ao Guarapes e à Macaíba, pela estrada do sertão. No lugar do aglomerado popular das Rocas, um novo "bairro das Dunas, cingido (...) pela avenida BeiraMar", destinado à população cosmopolita organizada em torno do porto. A Cidade Alta núcleo urbano original - não resistiria à força dos novos tempos: "O aborígine quis opor à invasão do progresso o dique de suas tradições; porém, dia a dia, as casas se transformam, as ruas se alargam, a vida circula, impetuosa, febril, dominadora". Do outro lado do rio Potengi, atravessado por inúmeras pontes, surgiria "uma cidade imensa, ou antes, estendem-se filas de armazéns, oficinas, docas, casas de negócio, albergues, estalagens, casas de campo". ${ }^{75}$

Algumas dessas idéias se transformariam em propostas ou seriam concretizadas nos anos e décadas seguintes. O bairro das Dunas no lugar das Rocas, por exemplo, reapareceria como um "bairro operário" no Plano Geral das Obras de Saneamento de Natal do engenheiro Henrique de Novaes, em 1924; e como um "bairro-jardim" no Plano Geral de Sistematização do arquiteto Giacomo Palumbo, entre 1929 e 1930, que Cascudo sintomaticamente chamaria de "cidade novíssima das Dunas", numa provável reminiscência da conferência de Manoel Dantas. $^{76}$

O caráter prospectivo da conferência externava portanto os anseios de parte da elite intelectual local para um "projeto" de modernização urbana que, com maior ou menor sucesso, tentava-se implantar desde a última década do século XIX. Com ênfase na estética e na técnica e tendo como modelo as grandes reformas urbanas européias - em especial a Paris de Haussmann - ou, no caso das cidades menores, o maior exemplo nacional, o Rio de Janeiro, a "Paris nos trópicos" do engenheiro Francisco Pereira Passos, as cidades brasileiras ou melhor, as suas elites - esforçavam-se por superar a estagnação econômica herdada do período colonial e todas as representações daí decorrentes. ${ }^{77}$

Assim, pode-se aventar que as "previsões" de Manoel Dantas, pelo menos no que concerne às transformações urbanas de Natal, são umas das primeiras verbalizações do "projeto" insistente que se formulava para a cidade e que seria depois articulado e ganharia corpo definitivamente com os planos urbanísticos da década de 1920. Ao atar as pontas de um passado distante e impreciso ao momento de refundação da cidade com a República, a conferência "Natal daqui a cinqüenta annos" ajudou, em sua versão mítica, a construir esse passado que se negava; em paralelo, ao apontar para o futuro, formou um retrato significativo dos intentos das primeiras elites republicanas.

\footnotetext{
${ }^{73}$ Ibidem, p.34.

${ }^{74}$ A esse respeito, veja-se por exemplo Vera Telles (1999).

75 Dantas, M., 1909, p.32-35.

${ }^{76}$ Cf. Cascudo, 1929c; em artigo anterior (1929b), Cascudo já havia citado explicitamente a conferência de Dantas ao falar sobre a Ribeira; os planos de Novaes e Palumbo serão discutidos nos capítulos 3 e 5 , respectivamente.

77 Deve-se ressaltar que esta referência à Paris não foi amiúde técnica ou concreta, mas emotiva, constituía-se como um modelo político e ideológico, um instrumento de propaganda e ilusão, como afirma Del Brenna (1985, p.09). O Rio de Janeiro teria um papel semelhante em relação às cidades brasileiras menores, como ressalta Pinheiro (2002; 1998), ao discutir o conceito de haussmannização e suas ressonâncias no Brasil, mais especificamente em Salvador e no Rio de Janeiro.
} 


\section{O bonde (ou o "caningado rapa-coco") da História}

O tema da construção da cidade moderna teria pelo menos dois desdobramentos importantes nos anos seguintes. O primeiro diz respeito ao esforço sistemático pela construção da história oficial do estado e, principalmente, da sua capital. O segundo surgiu no contexto da "crise" dos serviços e equipamentos urbanos por que Natal passou na virada para a década de 1920 e teve como síntese as formulações sobre a cidade do "já teve".

Ao lado dos ensaios, das pequenas monografias, das plaquetas resultantes de conferências, dos artigos especulativos e das crônicas em geral que, de alguma forma, abordavam a história da cidade, vieram a lume alguns trabalhos importantes e extensos. ${ }^{78}$ Resultado de pesquisas exaustivas, expondo e transcrevendo documentos compulsados em profusão, estabelecendo longas notas explicativas e organizando cronologicamente fatos e nomes, principalmente aqueles vinculados à história política, esses trabalhos começaram a consolidar e a transformar em estatuto a leitura ou interpretação sobre a história da cidade que vinha se desenvolvendo desde o início do século XX.

Os livros sobre a história do Rio Grande do Norte de Augusto Tavares de Lyra, publicado em 1921, e do historiador profissional Rocha Pombo, de 1922, destacam-se em meio a essa produção local de então. Diga-se isto não apenas pelo volume dos textos (o primeiro tem mais de oitocentas páginas e o segundo quase quinhentas), mas, principalmente, pelo maior rigor científico na escrita, na exposição de temas e assuntos e no uso das citações, pela indicação dos documentos consultados e pela transcrição, muitas vezes integral, dos registros do período colonial. $\mathrm{O}$ que os transformou em fontes primeiras aos estudiosos que se dedicaram ao tema posteriormente, incluindo aí o próprio Câmara Cascudo - sobre o qual discutiremos adiante -, ou mesmo os pesquisadores contemporâneos. ${ }^{79}$

Escritos sob os influxos das comemorações pelo Centenário da Independência e sob os auspícios do Instituto Histórico e Geográfico Brasileiro, os dois calhamaços se aproximam no interesse de construir uma história em evolução cujo ponto de chegada é a República; de sedimentar uma memória que estabelecesse não um, mas "o passado comum" que legitimasse as ações e os "projetos" contemporâneos das elites dirigentes; de buscar nesse passado a matéria-prima ou o ponto de partida para especular e projetar o futuro; de, principalmente em Tavares de Lyra, delimitar uma região e um estado, demonstrar-lhe as contribuições à constituição da Nação, apontar-lhe os traços singulares que a/o diferenciam dentro da (história da) Federação e, assim, reivindicar-lhe necessidade e atenção próprias. ${ }^{80}$

Membro da elite dirigente, ex-governador do estado, ocupante de cargos federais importantes, tanto no legislativo quanto no executivo - foi Ministro da Justiça e Ministro de Viação e Obras Públicas, a qual estava subordinada a IFOCS -, a "tarefa" do historiador aparece mais premente para Tavares de Lyra. Atuando como jurista no início do século XX, foi uma das principais vozes em defesa do estado na questão dos limites geográficos com o Ceará. Seria a partir dos estudos históricos e da documentação existente sobre o período colonial no Brasil que construiria sua argumentação jurídica. Evocando cartas régias, mapas antigos, éditos e cartas de vereação Tavares de Lyra ajudou a resolver, a favor do Rio Grande

\footnotetext{
${ }^{78}$ Como, por exemplo, o "Ensaio crorographico" sobre o RN, apresentado no Congresso Brasileiro de Geografia de 1915, e a monografia "Denominação dos municípios", de 1922, ambos de Manoel Dantas; as "Notas sobre a Ribeira do Apody", de Nonato Mota, publicado em 1921; ou, na Revista do IHGRN, os estudos de Luiz Fernandes sobre os "índios célebres do RN" e os de Alfredo de Carvalho sobre "os hollandezes no RN".

${ }^{79}$ Além do interesse para os historiadores locais, Tavares de Lyra produziu outras obras ainda hoje relevantes, principalmente pela compilação dos dados primários, sobretudo aquelas dedicadas às "Instituições políticas do Império", como afirma Murilo de Carvalho (1981, p.185-186).

${ }^{80}$ Cf. Odalia, N., 1997; Albuquerque Jr., 2001.
} 
do Norte, a querela entre os dois estados ${ }^{81}$ Essa experiência não só o inspirou a escrever e a sistematizar a história local, ${ }^{82}$ mas, pode-se dizer, foi decisiva para que compreendesse o "papel" da História para construção da legitimidade do projeto de modernização. Tarefa não muito diversa daquela pela qual se bateram, por exemplo, dois políticos e intelectuais importantes da Primeira República: Washington Luís e José Américo de Almeida. O primeiro ajudando a forjar a figura mítica do nobre bandeirante - o que era tomado como uma vocação original do desbravamento rodoviário e do papel central de São Paulo no concerto da Federação -, e o segundo construindo a imagem do "homem do norte" como o único capaz de entender e encaminhar as soluções para a região nordeste, que então começava a ser delimitada e tornada visível e dizível. ${ }^{83}$

Contratado pelo governo do estado e com o patrocínio do IHGB, Rocha Pombo se imbuiu na mesma tarefa de construção de uma história oficial local. Se o primeiro preocupouse em coligir e transcrever a documentação original a qual teve acesso, preenchendo a narrativa com longas citações, o segundo estabeleceu um texto mais rigoroso e minucioso, explorando a narrativa e a discussão e o cotejo das fontes primárias.

Mesmo assim, ambos seguem um itinerário semelhante: apontam o lugar central do médico Pedro Velho e do seu grupo político na articulação do movimento republicano no estado e, mais importante nessa leitura, na consolidação do regime e na concretização das reformas urbanas que teriam transformado a imagem decadente e atrasada da capital do estado. ${ }^{84}$ A construção de Natal como uma cidade de fato aparecia como o testemunho físico do significado de progresso e civilização advindo com o novo regime. Afirmar, como Rocha Pombo o fez, que "a edificação urbana já perdeu o aspecto colonial" 85 era atestar que os signos de atraso e decadência - a permanência do passado colonial na estrutura urbana da cidade - haviam sido superados.

Se é ponto comum a leitura que ambos empreendem sobre a importância do advento da República para a transformação de Natal, o mesmo não pode ser dito acerca da outra ponta dessa história - a fundação do núcleo urbano e a sua elevação à categoria de cidade. Para Tavares de Lyra, a condição de Natal como cidade nos seus anos iniciais era um fato inconteste, a despeito do seu ulterior desenvolvimento precário ou da mofa dos vizinhos: "Tem havido affirmações de que a povoação ou villa de Natal foi elevada à categoria de cidade durante o regime hollandez. Não é exacto. Antes da invasão batava, já Frei Vicente de Salvador e outros se tinham á cidade [...], havendo mesmo documentos officiaes que provam que o era". Dentre esses, o mais importante citado é o "Auto da repartição das terras da capitania do Rio Grande do Norte", de 1614, onde pela primeira vez é usado o topônimo Natal para designar o núcleo urbano existente. Tavares de Lyra observa ainda que o documento é datado da "cidade do Natal". Ademais, lembra que o termo do município de Natal foi estabelecido - e aqui cita o "Livro que dá Razão do Estado do Brasil", de Diogo de Campos - em 1611, pelo então Governador Geral D. Diogo de Menezes. ${ }^{86}$

Rocha Pombo, por sua vez, não nega que Natal logo foi cidade. "Em todo o caso, comquanto ainda insignificante, estava creada a povoação, a que se dava já o titulo de villa, e mesmo de cidade". Contudo, a única razão para explicar a titulação - empregada inclusive nos

${ }^{81}$ Cf. Tavares de Lyra, A., e Lemos, V., 1905a, 1905b; não à toa, essa querela marca a produção inicial da Revista do IHGRN (Cf. por exemplo vols. I a IV, 1903-1906, XI-XII-XIII, 1913-1915, e XVIII-XIX, 1920-1921); a convite do governador Alberto Maranhão, Rui Barbosa assumiu a incumbência de defender o RN junto ao Supremo Tribunal Federal; sobre a querela, Cf. Maranhão, 1903, p.04; 1904; 1908, p.11; 1913, p.21; Tavares de Lyra, 1904, p.05; Ferreira Chaves, 1915, p.05.

82 Cf. o prefácio de Carlos Tavares de Lyra à $3^{a}$ edição do "História do Rio Grande do Norte" (Tavares de Lyra, 1998); este livro seria a primeira parte de sua trilogia sobre (a história, a geografia e a etnografia de) o estado; desejo parcialmente concretizado com a publicação de "Chorographia do RN" (1924), em que traz algumas "notas ethnographicas".

83 Sevcenko, 1992, p.137-138; Reis, 1997, p.154-156; Almeida, 1923; Albuquerque Jr., 2001.

${ }^{84}$ Tavares de Lyra, 1921, p. 593-634; Pombo, 1922, cap. XVIII, “sob o novo regimen”.

85 Pombo, 1922, p.486.

${ }^{86}$ Cf. Tavares de Lyra, 1921, p. 693-697; o “Auto da repartição...” foi publicado na seção "Archivo" da Revista do IHGRN (vol. VII, n. 01-02, 1909, p.05-82). 
documentos oficiais -, afirma o historiador, estaria no uso popular de chamar qualquer povoação de vila ou cidade. Se era cidade de direito, não o era de fato, mesmo séculos depois da sua fundação. "Natal, que é o primeiro nucleo de população que ali se forma, até principios do seculo XIX não passava, pelas suas proporções, de uma pequena aldeia". Para comprovar essa assertiva e descrever Natal, Pombo apoiou-se largamente no relato (e no espanto) oitocentista de Koster. Este "(por volta de 1810 ou 1811) admirou-se muito de que se desse o nome de cidade a um grupo de casas menor do que muitas aldeias". ${ }^{87}$

Mesmo assim, a descrição que ambos empreenderam constrói um forte contraste entre o espaço urbano colonial e a cidade "transformada" do início dos anos 1920. Neste sentido, é importante observar as fotografias que ilustram o livro de Rocha Pombo. Sem relação direta com o texto, e enquadrando os principais espaços e edifícios da área central de Natal, constituem uma espécie de narrativa paralela que testemunha o "progresso" da cidade. Os planos fechados, o movimentos nas ruas e praças, o bonde em movimento, os senhores encasacados, enfatizam uma ordem urbana desejada e, afirmava-se, concretizada (ver figuras 2-01, 2-02, 2-03 e 2-04). Seria sintomático que, mesmo quando enquadraram temas mais dinâmicos, tais fotografias exprimam uma forte sensação de estaticidade?

Em contraponto à construção dessa história oficial da cidade - embora participe desse processo - é importante destacar uma das representações mais significativas que foram formuladas em meio à "crise" dos serviços e equipamentos urbanos que se exacerbou desde meados da década de 1910: a da cidade do "já teve". O artigo de fundo do número inaugural de um pequeno periódico, um dos muitos que se autodenominavam humorísticos e que tiveram vida curta nas primeiras décadas do século XX em Natal, talvez seja o primeiro registro dessa representação: "É nesta terra do já teve, aos dezesseis dias do ventoso e friorento mes de julho, do anno da graça do caningado bonde rapa-coco que lançamos aos quatro cantos do mundo, o numero primeiro d'A Plateia [...]". ${ }^{88}$

Formulação irônica que, se por um lado, tentava expressar a condição de efemeridade ou de retrocesso na condição de Natal como cidade civilizada, por outro lado e ao mesmo tempo, afirmava um momento anterior, próximo mas impreciso, é verdade, de posse do que se considerava moderno e progressista. Externava assim a insatisfação com a perda, ou melhor, a dificuldade de manter os signos modernos havia pouco instaurados. "[...] os dois unicos estabelecimentos de diversão [os cinemas Polytheama e Royal] de nossa capital [estavam] prestes para entrar para a galeria do "já teve", caso não fossem reformados e modernizados, afirmava um editorial de $1921 .^{89}$

A euforia e o entusiasmo com as reformas e a introdução de inovações tecnológicas e de equipamentos e serviços urbanos, principalmente na segunda administração de Alberto Maranhão (1908-1913), dava lugar, em parte da camada letrada local, ao pessimismo e à inquietação ante a precariedade da cidade..$^{90} \mathrm{O}$ antiprograma de abertura do jornal $\mathrm{O}$ Alfinete, em dezembro de 1915, expressa esse sentimento: "Não ha necessidade de artigo de fundo. Para que programma, se em Natal tudo é ephemero?". ${ }^{91}$ Uma crítica radical, talvez, que marca na própria condição de efemeridade do periódico a sua relação com uma cidade que, como tal, ainda estava em formação.

Não se pode deixar de mencionar que o tema da cidade do "já teve" incorporava também o olhar de fora que informara decisivamente a maneira como os intelectuais locais falavam e construíam as referências sobre a sua própria cidade. O sentimento de perda somava-se às elaborações sobre a cidade por se fazer, a cidade que não existia, e cuja condição

\footnotetext{
87 Pombo, 1922, cap. V e XVII.

88 "Artigo de fundo". A Plateia, Natal, n.1, p.1, 16 jul. 1916 (grifos nossos).

89 “Cinemas". Jornal do Norte, Natal, n.1, p.2, 17 jun. 1921.

${ }^{90}$ Cf. Soares, 1999, cap. 2.

91 "Para que". O Alfinete, Natal, n.1, p.1, 05 dez. 1915
} 
projetava-se no futuro, como afirmara Henry Koster no início do século XIX. Ademais, e este é um aspecto importante a destacar, esse tema permite entrever o modo como a massa de pobres e remediados, normalmente à margem do processo de modernização urbana, incorporava, "via", "lia" e, de certa forma, trazia ao seu cotidiano os signos modernos: com apelidos e gracejos que assomavam às páginas dos jornais, com versos populares e irônicos e, às vezes, reagindo com violência. $O$ bonde, por exemplo - cuja situação, como foi dito no capítulo 1, talvez tenha sido a melhor expressão das formulações sobre a "crise" dos serviços e equipamentos urbanos em Natal na virada para a década de 1920 -, era o "caningado rapacoco" a atravessar aos "cambolhões sem conforto" a cidade com seus guinchos e estalidos mecânicos, toda aquela ruidosa traquitana moderna que parecia desmanchar-se ao longo dos trajetos. ${ }^{92}$

\section{Fabulações para uma história da cidade (moderna)}

É desse conjunto de representações que Luís da Câmara Cascudo ${ }^{93}$ parte para construir a sua narrativa sobre a história da cidade. Embora se aproprie da produção historiográfica anterior, dos temas discutidos e, principalmente, dessa interpretação-chave que vinha se desenvolvendo desde o início do século XX, Cascudo não se limita a repeti-los ou atualizá-los. Em meio às discussões, influências e disputas intelectuais dos anos 1920, às aproximações e oposições entre regionalismo, tradicionalismo e modernismo, a cidade não é mais tomada (somente) por uma perspectiva "civilizadora", pelos discursos apologéticos do "progresso"; e nem o viés de condenação ou o olhar paternalista que enquadra como exótico ou pitoresco é mais o único meio para entender, descrever e se aproximar do espaço tradicional da cidade, dos hábitos e das relações sociais que aí se desenvolvem.

Assim, o novo e original registro cascudiano também não escapou, muito ao contrário, ao conjunto de discussões sobre o processo de modernização por que a cidade passava. De fato, a observação da cidade em transformação é tomada como objeto privilegiado da sua produção intelectual e literária desde os primeiros escritos. As crônicas cotidianas - quer abordando a situação do pedinte em Natal, a inadequação da moda européia ao clima tropical, a paisagem natural que circunda a cidade ou o desaparecimento das festas populares, por exemplo ${ }^{94}$ - revelam um observador atento que, ao assumir paulatinamente um papel de liderança e referência no meio intelectual local a partir dos anos 1920, seria decisivo na construção não somente da compreensão mas dos próprios significados desse processo.

Afirmar isto significa chamar a atenção para uma narrativa que, ainda em formação na década de 1920, tornar-se-ia hegemônica, principalmente depois da publicação do livro "História da Cidade do Natal", em 1947. Um marco na produção historiográfica local desde a sua primeira edição, a estrutura e a discussão do livro todavia não podem ser compreendidas sem uma olhar em perspectiva tanto para vários dos textos que Câmara Cascudo publicou nas duas décadas anteriores como para o debate técnico e intelectual que os secundara.

\footnotetext{
${ }^{22}$ Cf. (sem título), O Momento, Natal, n.1, p.4, 13 maio 1918; "No Baldo", Gazeta da Semana, Natal, n.1, p.3, 23 ago. 1914; "Um automovel vae de encontro a um bond", Diário de Noticias, Natal, n.1, p.1, 11 nov. 1914; "A falta de modos na moda", $A$ Palavra, Natal, n.1, p.2, jul. 1921. Uma breve explicação etimológica: o adjetivo "caningado" - sem registro no dicionário Aurélio - costuma ser utilizado para pessoas que repetem, de forma seguida, irritante e insistente, uma mesma conversa; os ruídos feitos pela passagem do bonde eram ainda assemelhados ao som do instrumento manual utilizado para raspar a polpa do coco.

${ }^{93}$ Nasceu em Natal em 1898 e faleceu na mesma cidade em 1986; filho único de uma família abastada, para os padrões locais no início do século XX, e próxima ao círculo de poder em Natal, Cascudo teve uma educação privilegiada desde cedo; começou a escrever n'A Imprensa, diário de propriedade do seu pai, o Coronel Francisco Cascudo; estudou Medicina no Rio de Janeiro até o quarto ano mas acabou se formando bacharel em Direito, pela Faculdade do Recife, em 1927; a obra de Cascudo é imensa - com mais de 150 publicações, entre livros e plaquetes, além de uma rica marginália e uma prolífica correspondência - e ainda pouco estudada.

94 Esses são alguns dos temas discutidos por Cascudo em suas primeiras crônicas n'A Imprensa, em 1918, segundo a bibliografia anotada por Zila Mamede (Cf. Mamede, 1970, vol. I, p.163-168).
} 
Em meio aos muitos temas discutidos e à irregularidade da escrita ensaística que marca o livro, oscilando entre a história, a memória e a literatura, ${ }^{95}$ há dois capítulos em especial (o XV, "Cidade Alta e Ribeira", e o XXII, "Xarias e Canguleiros") que nos ajudam a compreender a consolidação dessa narrativa sobre a história da cidade. Mais ainda - e este aspecto interessa sobremaneira a esta pesquisa e à tese que conforma este capítulo -, delimitam o momento preciso em que Natal teria superado a sua condição de não-cidade, em que teria deixado para trás as razões que justificavam o remoque colonial "Não ha-tal, natal".

$\mathrm{Na}$ narrativa de Cascudo, os anos 1920 conformaram esse momento de fundação da cidade (moderna), em que Natal assumiria a condição que lhe foi outorgada havia mais de três séculos. A leitura sobre a reforma da Avenida Junqueira Ayres é muito emblemática para a interpretação desse processo.

A Junqueira Ayres, no final da década de 1920, era a avenida por onde passavam os bondes e os ônibus, desciam as normalistas e estudantes rumo à Escola Doméstica; rumo à Av. Tavares de Lira, iam-se às vitrines à moda parisiense, aos cafés e rotisseries e aos pontos chics de reunião, passear a elegância e o spleen de Natal; assistir as regatas no rio Potengi ou aos espetáculos e filmes do Cine-theatro Carlos Gomes e do Politheama. Pela Av. Junqueira Ayres passavam muitos daqueles que tinham seus afazeres entre os bairros da Ribeira e da Cidade Alta. O seu calçamento defeituoso, além de um entrave à circulação na pequena capital, era a lembrança de um passado que não se queria para Natal; o passado expresso nos antigos topônimos - antiga Ladeira, Subida da Ladeira ou rua da Cruz - que designavam o único e difícil acesso, a "ladeira íngreme, escorregando como sabão depois das chuvas", ${ }^{96}$ entre os dois núcleos primeiros que configuravam o espaço urbano da Natal do período colonial. Diria Cascudo:

\footnotetext{
"O antigo aterro colonial foi lentamente sendo substituído por pedras soltas, empedrado, trilha, calçada, paralelepípedo. Várias vezes o aclive foi rebaixado. A história termina quando o prefeito Omar O'Grady venceu o barro, tirou as pedras e vestiu a ladeira com o calcamento que resiste a tempo, água e esquecimento". ${ }^{77}$
}

A história que terminava era aquela do passado colonial. "O prefeito Omar O’Grady pôs Natal no caminho do século XX. Estava [ainda] no XVIII". 98 Embora não quisesse resumir todo um processo de transformação em apenas uma década ou nos seis anos de administração de Omar O'Grady, ou mesmo em uma única obra de reforma urbana, o calçamento da Junqueira Ayres adquiria, para Cascudo, uma importância chave para simbolizar ou sintetizar essa passagem para uma cidade moderna.

A cidade colonial aparece como uma cidade fragmentada, bi-partida, separada pela própria conformação fisiográfica, pela, como seria tematizada durante o século XIX e início do XX, terrífica e "miasmática" Campina da Ribeira. Um dos traços característicos desta separação entre os dois núcleos primeiros da cidade estaria na tradição "belicosa" das disputas, escaramuças e brigas entre os homens dos dois bairros, que perduraram do século XVIII até o terceiro quartel do século XIX, e que poderia ser resumida no grito de guerra que os separava: "Xaria não desce! Canguleiro não sobe!"

A mofa de ambos provinha da alimentação preferida em cada bairro no final do período colonial. Xaria, morador da Cidade Alta, era o comedor do xaréu (do gênero Caranx). Canguleiro, morador da Ribeira (cidade baixa), era o comedor do cangulo ou peixe-porco

\footnotetext{
$95 \mathrm{O}$ ensaio como elemento central e estrutural na escrita de Cascudo é discutida por Araújo, H. H. (1998).

${ }_{96}$ Cascudo, 1947, p.148.

${ }^{97}$ Ibidem, p.149; grifos nossos.

98 Ibidem
} 
(Balistes carolinensis). ${ }^{99}$ A nominação, contudo, não explicava a dissensão, a rivalidade que durou décadas. "Moleques, valentões, meninos de escola, desocupados, praças do Exército [cujo quartel ficava na Cidade Alta] e do então Batalhão de Segurança [sediado na Ribeira] mantinham o fogo sagrado dessa separação inexplicável", que tinha como palco privilegiado das batalhas de "espadas de arco de barril, pedradas, areia e insultos dignos de toda a malandragem de um morro carioca", o beco do tecido (atual rua Juvino Barreto), aos pés da rua da Cruz, a Junqueira Ayres, quase sempre depois das festas populares e religiosas. ${ }^{100}$

Pondo de lado a discussão dos aspectos sociológicos ou antropológicos desta rivalidade que fez parte da tradição popular e oral da cidade, ${ }^{101}$ importa observar que o esmaecimento desta "separação inexplicável" estaria estreitamente vinculada ao processo de modernização da cidade e à introdução dos melhoramentos e novos equipamentos urbanos, em especial os novos meios de transporte: inicialmente o bonde a burros, em 1908, e elétrico, a partir de outubro de 1911, e os automóveis e "auto-omnibus" na década seguinte. A facilidade de comunicação entre os dois núcleos seria decisiva e consolidaria, nos anos 1920, a transformação e passagem para a cidade do século XX. A afirmação de Cascudo é muito significativa a este respeito, embora tenha permanecido em aberto por sugestivas reticências: "O calçamento da avenida Junqueira Ayres levou esse elemento a ponto de fusão. Misturaramse, confundiram-se, uniformizaram-se. Xarias e canguleiros morreram. Ficou o Natalense..."102

Sem a pretensão de se estabelecer uma exegese ou "arqueologia" do texto do livro "História da Cidade do Natal", é importante destacar que esta interpretação de Cascudo estruturou-se no calor das discussões dos próprios anos 1920, como pode se depreender dos muitos artigos e livros que escreveu neste período. Mais ainda, temas, trechos e capítulos do livro podem ser encontrados, por vezes ipsis literis, em vários desses escritos, como "Joio" e "Histórias que o tempo leva", ambos de 1924, ou o artigo "Cidade do Natal", de 1926.

Em "Joio", por exemplo, livro de crônicas, alguns quase contos e crítica literária, ${ }^{103} \mathrm{O}$ tema da cidade em transição é claramente marcado. É a cidade da "fortaleza [que] dormita, toda negra, massiça e quadrada, guardando, ha trez seculos, a terra pequena que se chama Natal"; espaço de, pelo menos, duas temporalidades distintas: o da cidade moderna, dos sons barulhentos, do cinema e dos bondes, que à noite se recolhe e cede lugar ao silêncio, à quietude das ruas da cidade antiga, às "notas graves do sino da cathedral". O povo aparece, para Cascudo, alheio aos movimentos em ambas cidades: "nas ruas distantes, n'um amontoado informe de casinhas, o povo dorme, fatigado, embrutecido, alcoolisado, esquecido do amanhã, da luta de hontem, do horror de hoje". ${ }^{104}$

Para além dos procedimentos literários - que possibilitavam-no, por exemplo, entabular uma conversar esclarecedora com o presidente Parrudo, governante da província do Rio Grande do Norte em 1838 -, ainda era possível vislumbrar, nos anos 1920, o tempo da cidade antiga. Cidade para a qual se voltava quando se enfastiava da "civilisação e dos

\footnotetext{
99 Observe-se que o Dicionário Aurélio, pelo menos em sua mais recente edição (CD-Rom Novo Aurélio Século XXI, ed. Nova Fronteira, 2000), incorpora os dois termos, xaria e canguleiro, pelo seu significado sócio-geográfico em Natal. 100 Cascudo, 1947, p.233-35.

101 As razões desta rivalidade, que não se restringia aos motejos e anedotas depreciativas de um bairrismo etnocêntrico, poderia ser discutido, como aventa Veríssimo de Melo, à luz da antropologia e psicologia sociais (1968, p.11-18), a partir da permanência de algumas características culturais dos povos primitivos da região, os Petiguara (ou Potiguares), pertencentes à família lingüística Tupi-Guarani. De qualquer maneira, se Cascudo registra um declínio desta tradição antes de 1880, Veríssimo aponta de forma sugestiva a sua transferência para os esportes no século XX: por exemplo, em 1915 foram fundados o $\mathrm{ABC}$ e o América, ainda hoje os principais clubes de futebol do estado; o primeiro pelos jovens da Ribeira, canguleiros portanto, e o segundo, alguns meses depois, pelos da Cidade Alta. "Um dos fundadores do ABC, Vicente Farache, confessou-nos que eles sempre exploraram essa rivalidade nos prélios contra os xarias do América” (Ibidem). 102 Cascudo, 1947, p.235; grifos nossos.

103 A crítica de Cascudo, que havia se voltado para os autores potiguares em "Alma patrícia" (1921), com o intuito de estabelecer uma tradição literária local (Cf. Araújo, H.H., 1998; 1995), arvorava-se agora ao debate nacional, pondo em tema livros de autores como Menotti Del Piccia, Roquette Pinto, Agrippa de Vasconcelos, Lucilo Varejão, Jorge de Lima, Gustavo Barroso, dentre outros (Cf. Cascudo, 1924a).
}

${ }^{104}$ Cascudo, 1924a, p.16-18, "Natal à noite". 
confortos de hoje" e pela qual transitava, não por meio dos livros ou nas andanças pelos "velhos logradouros", mas pela memória dos que viveram o século XIX e ainda resistiam às primeiras décadas do XX. Se há um apelo nostálgico nesse escrito - quando afirma sofrer a saudade de um tempo que não viu -, esse sentimento é claramente mediado pelas representações de um "triste homem de uma civilisação requintada", como Cascudo se qualificaria, o que o impedia de compreender totalmente uma época a qual chama de "estranha". ${ }^{05}$

O esforço de aproximação, ou recriação, do passado por meio da literatura exacerbase em "Histórias que o tempo leva...". Esse procedimento não é exclusivo de Cascudo: a literatura, para a sua geração, muito mais do que um "campo privilegiado dos recursos expressivos da linguagem", é uma referência para compreender e discutir os mais variados aspectos da vida social. ${ }^{106}$ Nesse livro - resenhado por Gilberto Freyre e Mário de Andrade -, o escritor apenas aparentemente cede lugar ao historiador. A representação do passado surge como uma narrativa em que se amalgamam os fatos históricos oficiais e as lendas, os mitos, os elementos da memória coletiva da cidade. Nesse sentido, é exemplar a leitura que empreende da lenda que se criou em torno da morte do holandês Pieter van Broeck. Lenda que é transformada em enredo literário que, por sua vez, passa à história da cidade - e a assombraria ainda. ${ }^{107}$

As narrativas sobre o período do jugo holandês ou sobre a passagem de Koster por Natal, em 1810, revelam ainda o manuseio das fontes originais que fundamentariam a (re)escrita de Cascudo sobre a história da cidade. As imagens da cidade diminuta, desvinculada da rede urbana do período colonial e, por isso, tacanha e sem desenvolvimento são iluminadas pelos documentos dos viajantes.

Entretanto, a primeira tentativa de Cascudo de sistematização da história da cidade aparece no artigo "Cidade do Natal", publicado num periódico local em 1926. A apropriação da narrativa histórica que se delineava desde o início do século revela-se na afirmação de que embora fosse "cidade desde o nascimento", Natal chegava ao século XX apresentando a mesma "estrutura do século XVIII. As mesmas praças, ruas e limites". Para tanto, constrói seu breve artigo comparando os vários relatos aos quais teve acesso, citando em especial as descrições do espaço urbano - ou de um espaço que não existia. ${ }^{108}$

Da paupérie dos primeiros trinta e quatro anos de um arruado com título de cidade que só interessava aos portugueses como ponto de defesa territorial até a incipiente organização social que emergiu no século XIX - a pretensão da assunção de ares urbanos por meio de um bosquejo de legislação urbana, impondo normas de civilidade, respeito ao silêncio e ao decoro da vida urbana -, poucos fatos faziam-se dignos de notar, como o período sob ocupação holandesa, quando passou a chamar-se Nova Amsterdan. A cidade, "mui decaída", não interessou ao holandês, preocupado apenas com o desenvolvimento da pecuária para o abastecimento das capitanias de Pernambuco e Itamaracá. Assim, seguiram-se os séculos, num contínuo esforço de manutenção precário onde as débeis reclamações do Senado da Câmara mendigavam qualquer reconhecimento àquela cidade de origem mas quase sem vida. Essa trajetória poderia ter culminado na mudança da capital para Caraubinha, proposta do presidente da província em 1873, Henrique Pereira de Lucena, por considerar Natal "uma vila insignificante e atrasadíssima do interior". Desta forma, Cascudo, na conclusão do artigo, afirmava que "toda a atual cidade é uma conquista. Um trabalho moderno". ${ }^{109}$

\footnotetext{
105 Ibid., p.49-51, "O passado vivo".

106 Araújo, H.H., 1998, p.09.

107 Cf. Cascudo, 1924b, p.34-42; essa relação entre a faceta de escritor e de historiador de Cascudo é discutida por Araújo (Ibid.)

108 Cascudo, 1926.

109 Ibid., p. 18-34 passim.
} 
Mas este trabalho moderno era ainda mais recente do que aqueles apontados por Eloy de Souza; remontavam aos esforços de superação do clima decadentista que se instaurara no início dos anos 20 e situava-se dentro do ciclo de reformas urbanas empreendidas, em especial, pelo engenheiro Omar O’Grady a partir de 1924.

Esta interpretação - que tematiza os anos 1920 como o período chave para entender a transformação de Natal em uma cidade de fato - apareceria de forma clara nos dois artigos que escreveu por ocasião da exposição aberta ao público do Plano Geral de Sistematização no prédio da Intendência Municipal.

A discussão do plano abria possibilidades para discutir a própria história da cidade e os significados da sua condição durante o período colonial para a trama urbana herdada. As representações em negativo dessa herança ilustram as descrições que estabelece. As ruas do bairro comercial da Ribeira, por exemplo, abrir-se-iam - a partir das reformas contidas no plano - perpendicularmente ao rio em diversas praças. Destruía-se, assim, a "teia de aranha das ruas irracionais", a tortuosidade que lembrava um "delírio de linhas convulsas", o desmantelo, "os exemplos dos caminhos trêmulos e indecisos das cidades doentes de coloração estética", cujos únicos remédios eram um fósforo e duas latas de querosene, como propôs o engenheiro Sampaio Correia - e lembraria Câmara Cascudo - em visita a Natal no mesmo período. ${ }^{110}$

Entretanto, a proposta de Palumbo estava distante de fazer tábula rasa, consentiria Cascudo, citando Raymond Unwyn e apontando o pragmatismo dos urbanistas americanos. Era "a utilização da massa citadina num plano racional de correção. Correção na parte existente", 111 correção dos confusos valores herdados do passado. Os esforços de modernização passavam pela vitória do homem sobre a natureza - "duma situação topográfica que não consentiu que a indiferente atenção dos homens desvirtuasse o que naturalmente estava feito" vontade dentro de alinhamentos invisíveis [que deram] bem cedo o plano disparatado d'uma cidade em curvas, oblíquas e ângulos agudos". ${ }^{113} \mathrm{O}$ desleixo e descompromisso do ruador lusitano, tão bem ilustrada na história de Natal lida por Cascudo, era então afrontada pela atitude moderna e segura de traçar retas. A descrição da Ribeira no Master Plan de Palumbo demonstrava uma audácia respeitosa, onde "tudo ou quase tudo se poupou. Os traçados obedeceram a linha tradicional paralelas e verticais ao rio. Apenas o braço do homem alinhou raciocinadamente os valores confusos que herdamos em nome da cidade." "Valores confusos que caracterizavam esta cidade em latência, "uma massa esperando aspecto", uma natureza, bela e selvagem, esperando o esforço racional do homem para dar-lhe forma.

Cascudo, muito mais do que explicar, ajudaria a construir assim o processo de modernização por que Natal passava; a transformação de uma cidade a-histórica, como se afirmava, para uma outra, moderna, adequada às exigências da circulação e do comércio, do automóvel e do avião.

\footnotetext{
${ }^{110}$ Cascudo, 1929a

${ }^{111}$ Idem, 1929b.

${ }^{112}$ Cascudo, 1929a.

113 Ibid.

${ }^{114}$ Idem, 1929b.
} 


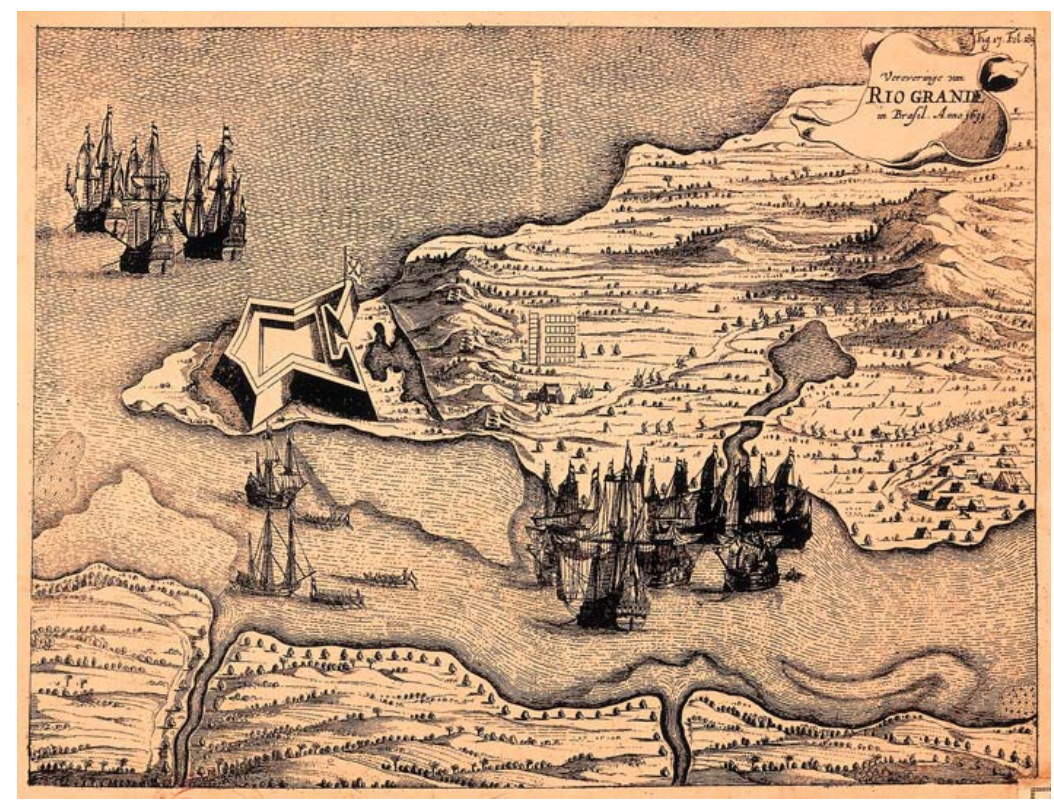

Fig. 1-01: "Veroveringe van RIO GRANDE in Brasil. anno 1633". Uma das muitas gravuras, possivelmente de Johannes de Laet, elaboradas pelos holandeses para divulgar as suas conquistas no nordeste do Brasil na primeira metade do XVII; à esquerda a Fortaleza dos Reis Magos, ao centro o que seria depois conhecido como Campina da Ribeira, e no canto inferior direito apenas uma indicação da localização de Natal, chamada de "aldeia dos portugueses" (Cf. Reis, 2000; Miranda, 1999).

Fonte: Reis Filho, 2000.

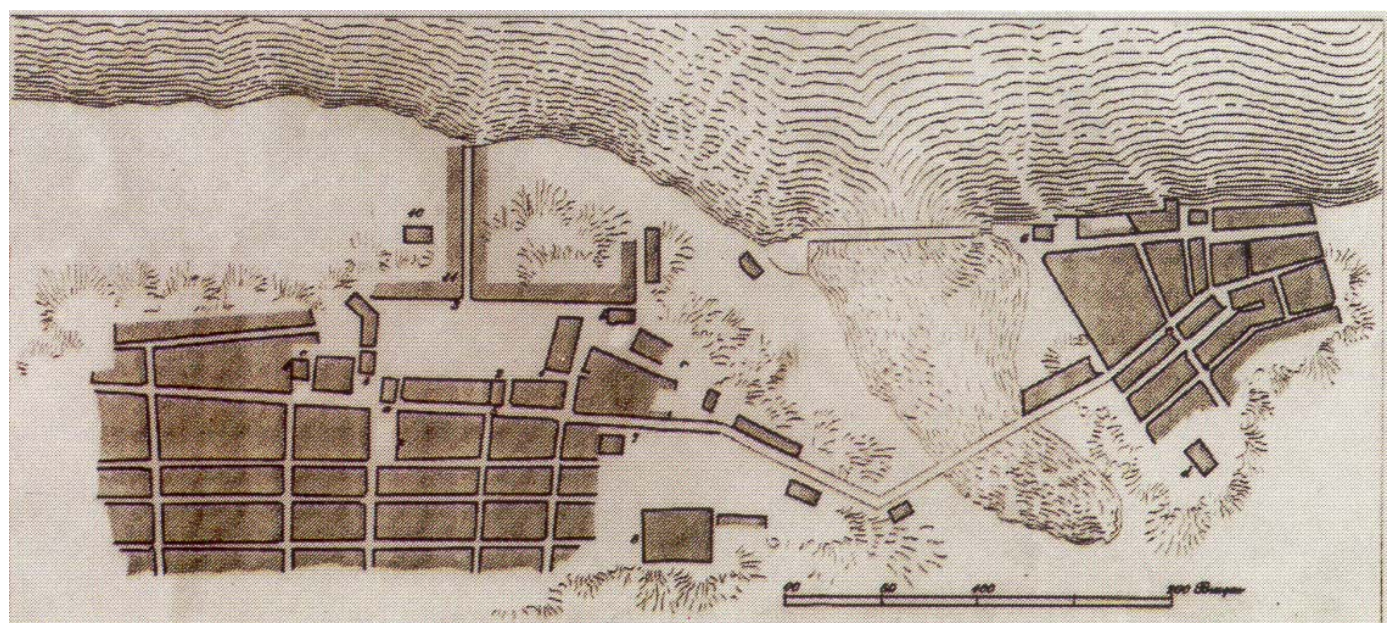

Fig. 1-02: Primeiro mapa conhecido de Natal (em que deixa de ser mero apenso gráfico à descrição da costa e da barra de entrada), elaborado em 1864 e presente no Atlas do Império do Brasil, de Candido Mendes de Almeida (1868). À esquerda a Cidade Alta (o vazio era a chamada Rua Grande, depois Praça André de Albuquerque) e à direita a Ribeira; a separar os dois bairros, a miasmática Campina da Ribeira. Fonte: Acervo Olavo de Medeiros Filho. 


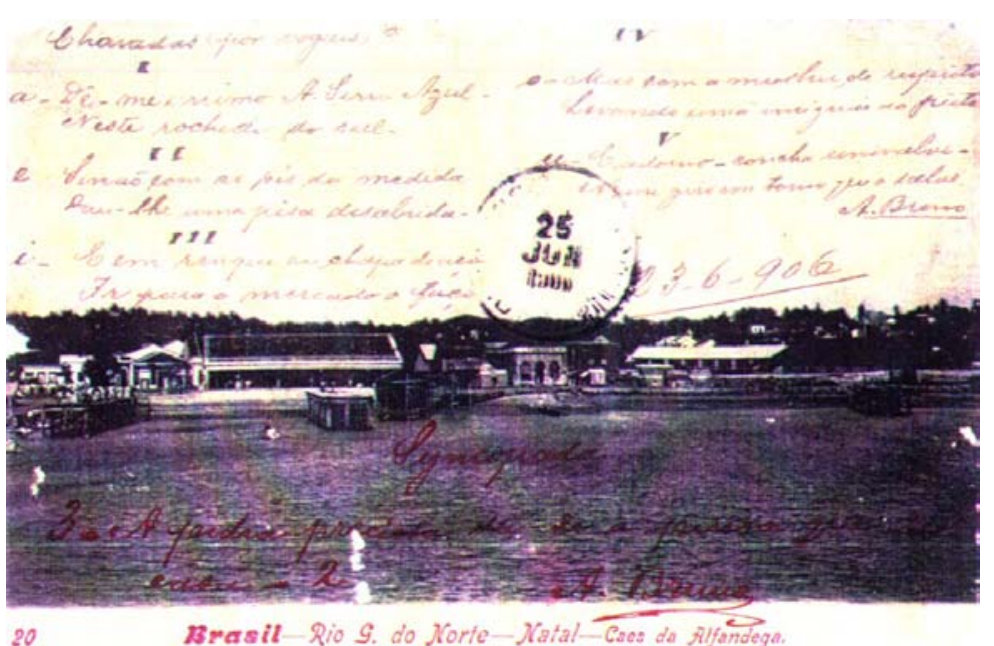

Fig. 1-03: Postal (com data manuscrita) de 1906 do "Caes da Alfandega" de Natal . Fonte: Acervo Diário de Natal.

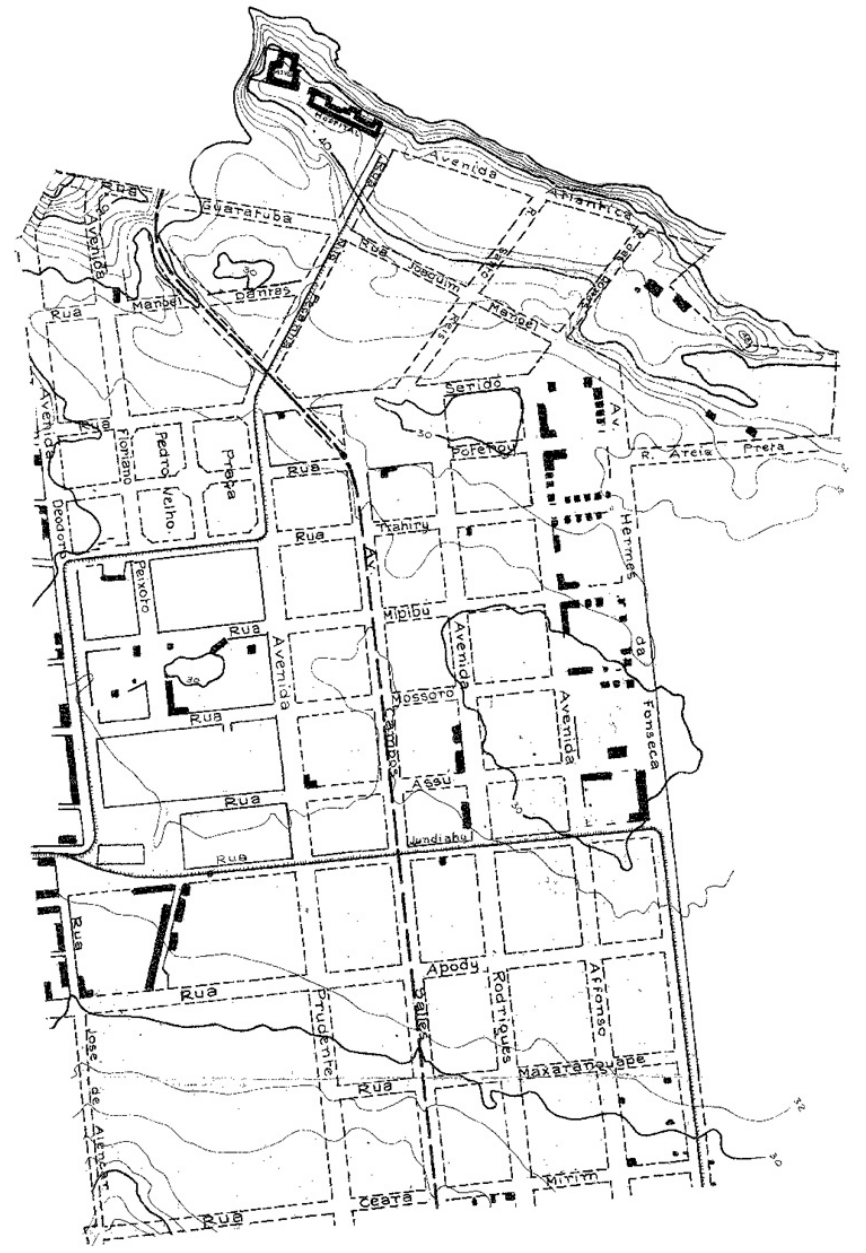

Fig. 1-04: planta da Cidade Nova elaborada pelo arquiteto João Maurício (Cf. Miranda, 1981) a partir da descrição de Cascudo (1947, p.351-355; por sua vez, baseado no relatório do secretário de governo em 1904, Henrique Castriciano) e sobre a base cartográfica da década de 1970; o traçado da malha em xadrez foi iniciada em 1901 com o funcionário da intendência municipal Jeremias Pinheiro da Câmara e concluído em 1904 pelo agrimensor italiano Antonio Polidrelli, "quase no aspecto de nossos dias" (Ibidem, p.354); contudo, há algumas incongruências entre esta planta e a descrição de Cascudo que só poderiam ser superadas caso fosse localizada a planta cadastral organizada entre 1907-08. Fonte: Ferreira, 1996. 


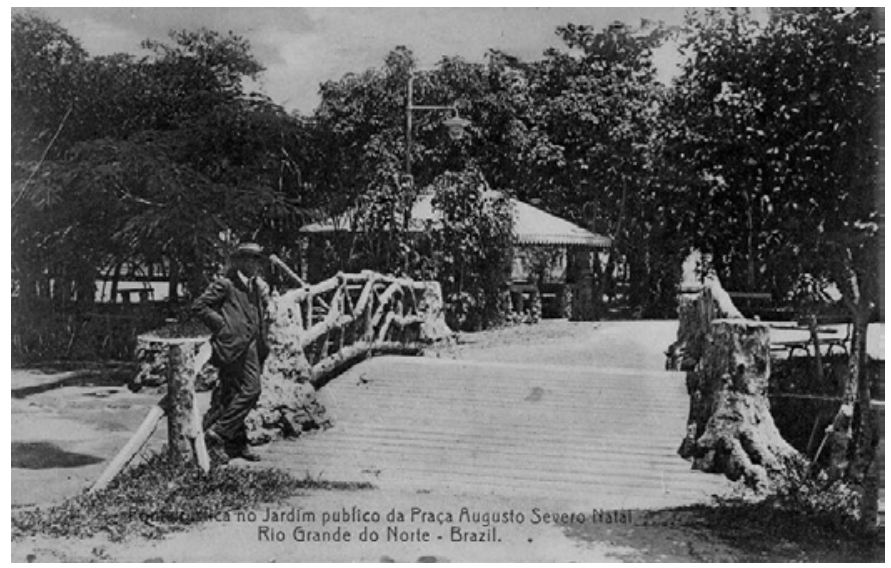

Fig. 1-05: cartão-postal da década de 1910 cujo tema era a Praça Augusto Severo e o seu jardim público pitoresco, projetado e construído sob a direção do arquiteto Herculano Ramos; ao lado do Teatro Carlos Gomes, compôs um dos principais loci de novas sociabilidades de Natal na Primeira República. Fonte: Acervo Diário de Natal.

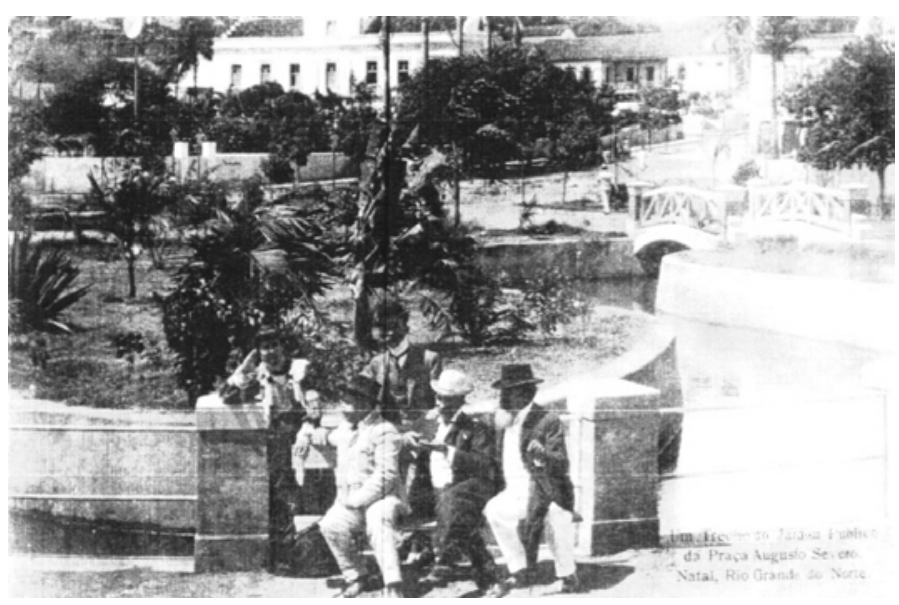

Fig. 1-06: pormenor da Praça Augusto Severo em cartão-postal da década de 1910. Fonte: Acervo Diário de Natal.

Theatro Carlos Gomes Natal . Rio Grande do Norte - Brazil.

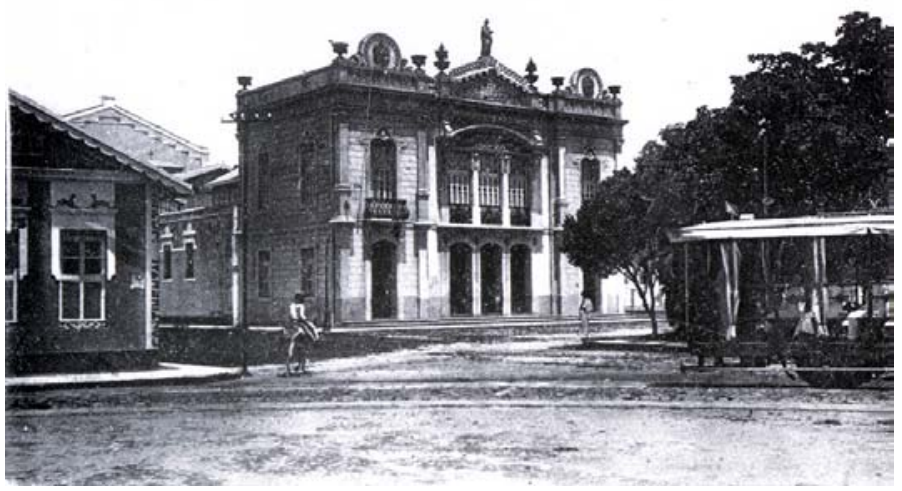

Fig. 1-07: Teatro Carlos Gomes (atual Alberto Maranhão) em cartão-postal da década de 1910; as árvores à direita indicam parte da praça Augusto Severo. Fonte: Lyra, 2001, p.45. 


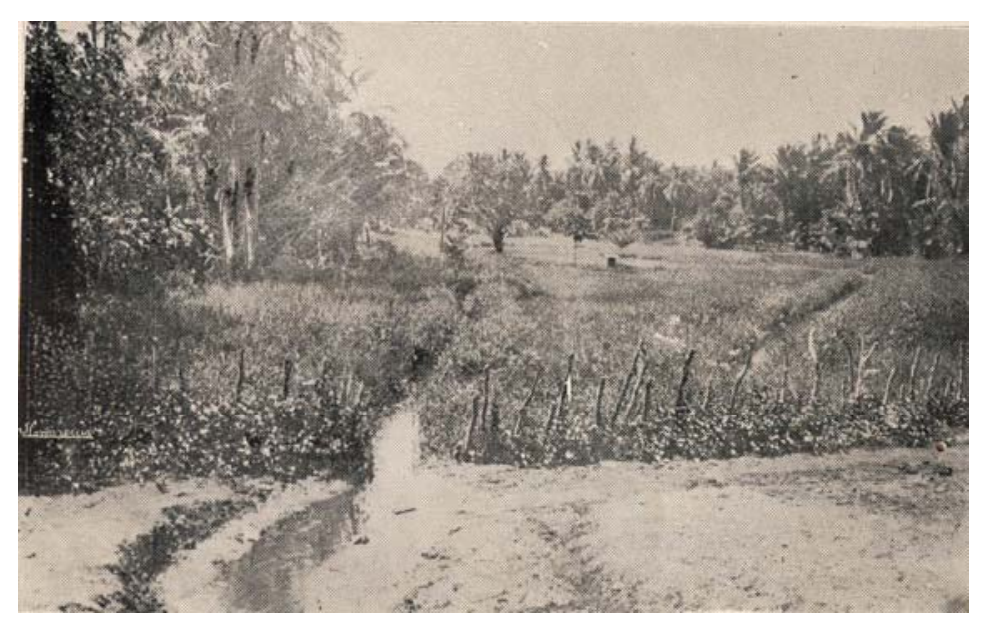

Fig. 1-08: Terrenos de propriedade da ETFL, no Baldo.

Fonte: Cicco, 1920.

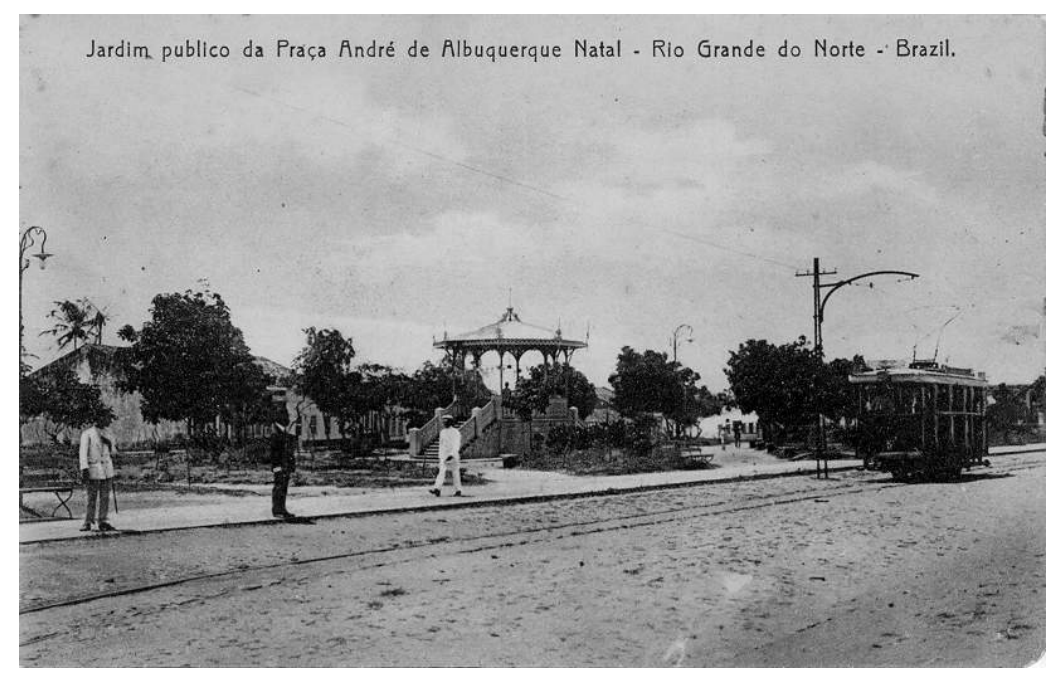

Fig. 1-09: O bonde e a cidade - Praça André de Albuquerque, Cidade Alta Fonte: Acervo Diário de Natal

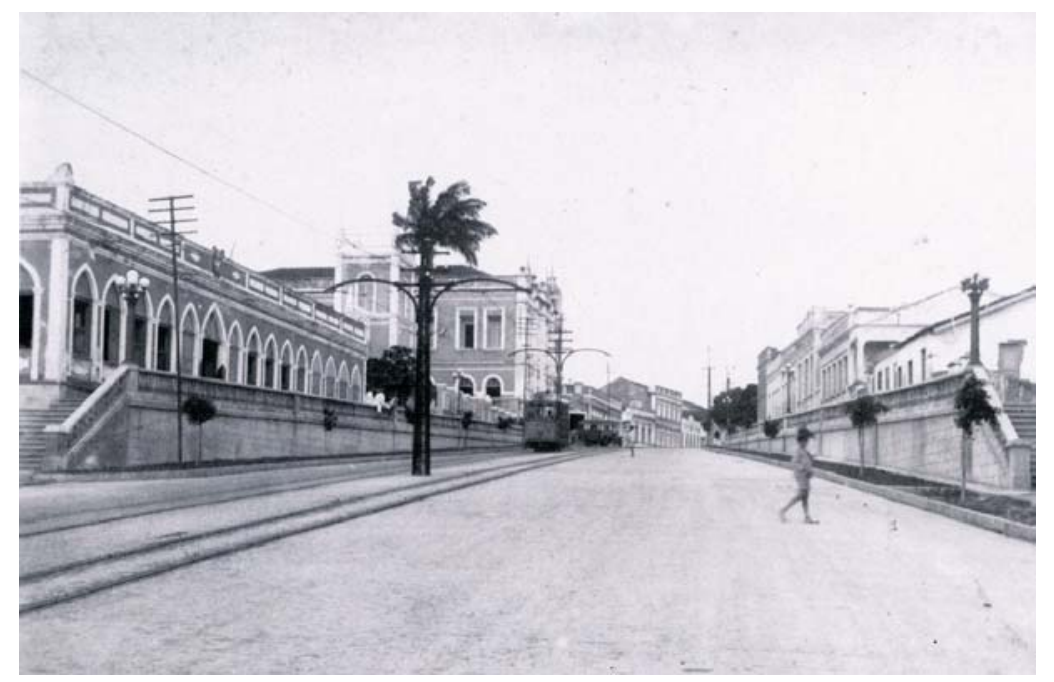

Fig. 1-10: O bonde e a cidade - descendo a Av. Junqueira Ayres. Fonte: Lyra, 2001. 


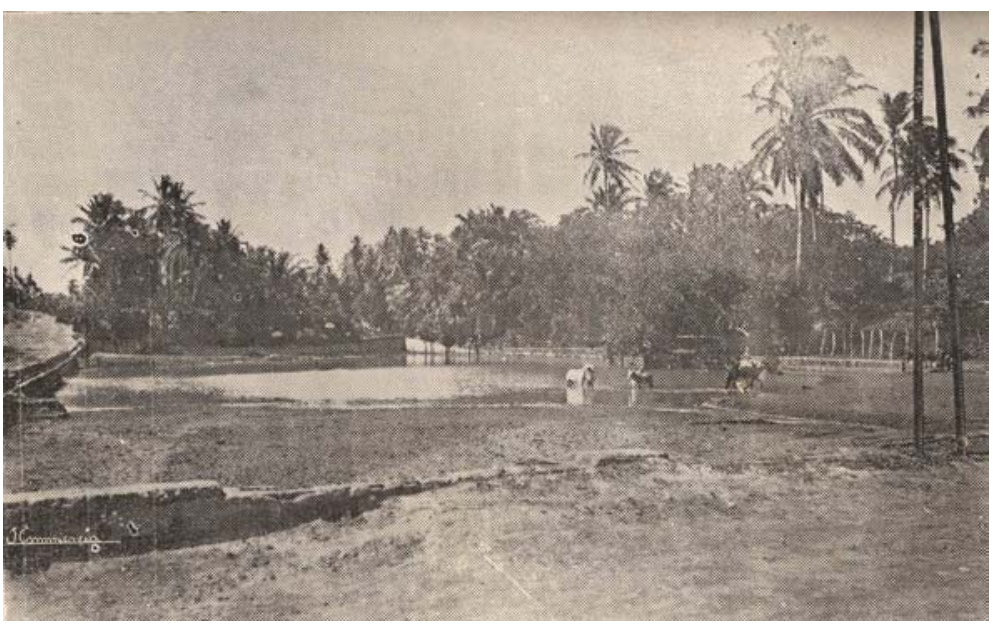

Fig. 1-11: A fonte pública do Baldo... e os animais dividindo o consumo com os homens Fonte: Cicco, 1920.

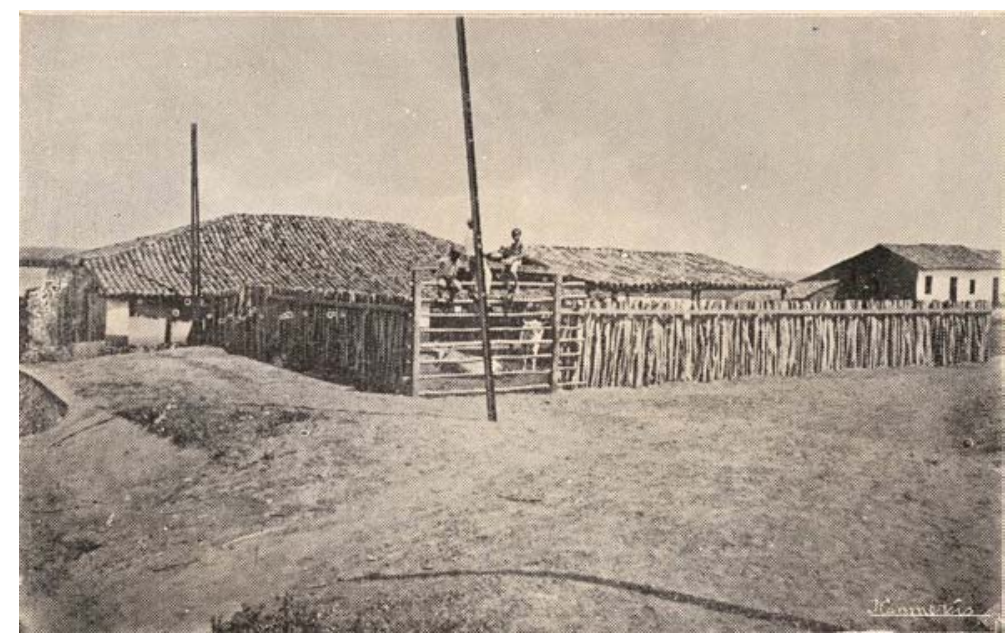

Fig. 1-12: a precariedade do matadouro público Fonte: Cicco, 1920.

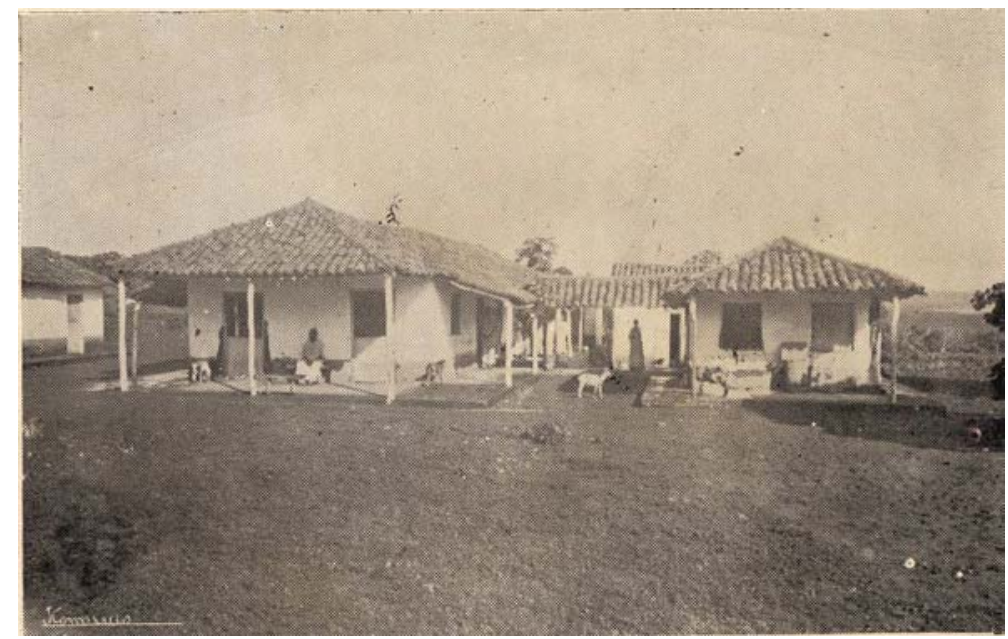

Fig. 1-13: O Isolamento de variolosos São Roque Fonte: Cicco, 1920. 


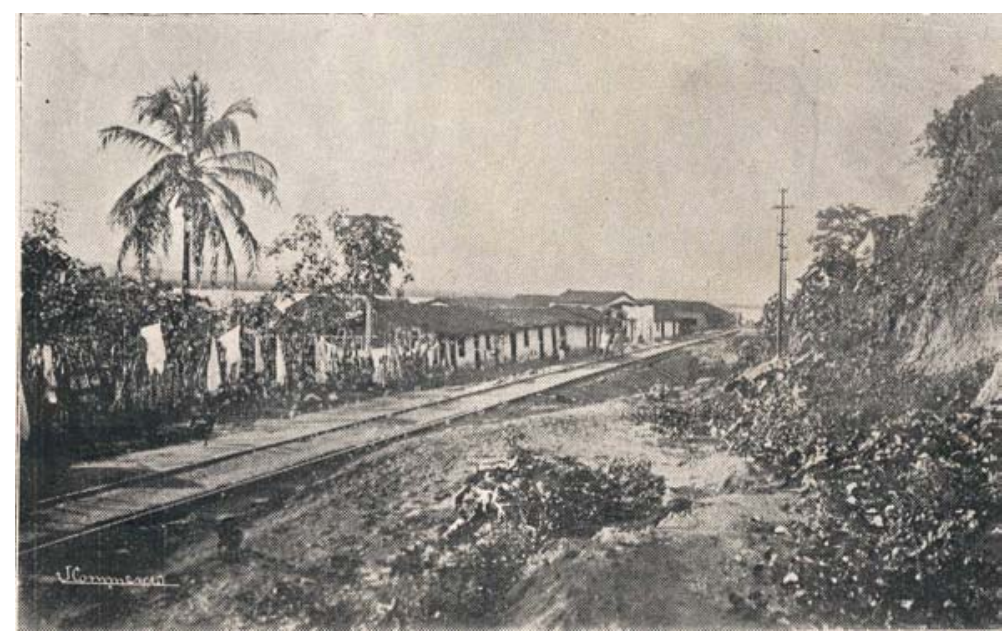

Fig. 1-14: a precariedade do matadouro público Fonte: Cicco, 1920.

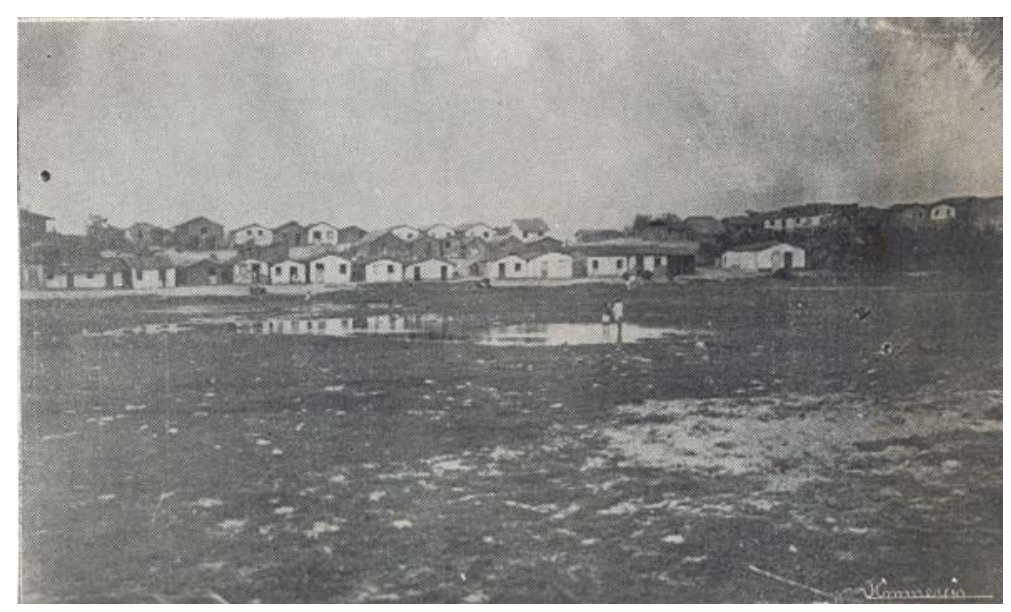

Fig. 1-15: vista do bairro das Rocas Fonte: Cicco, 1920.

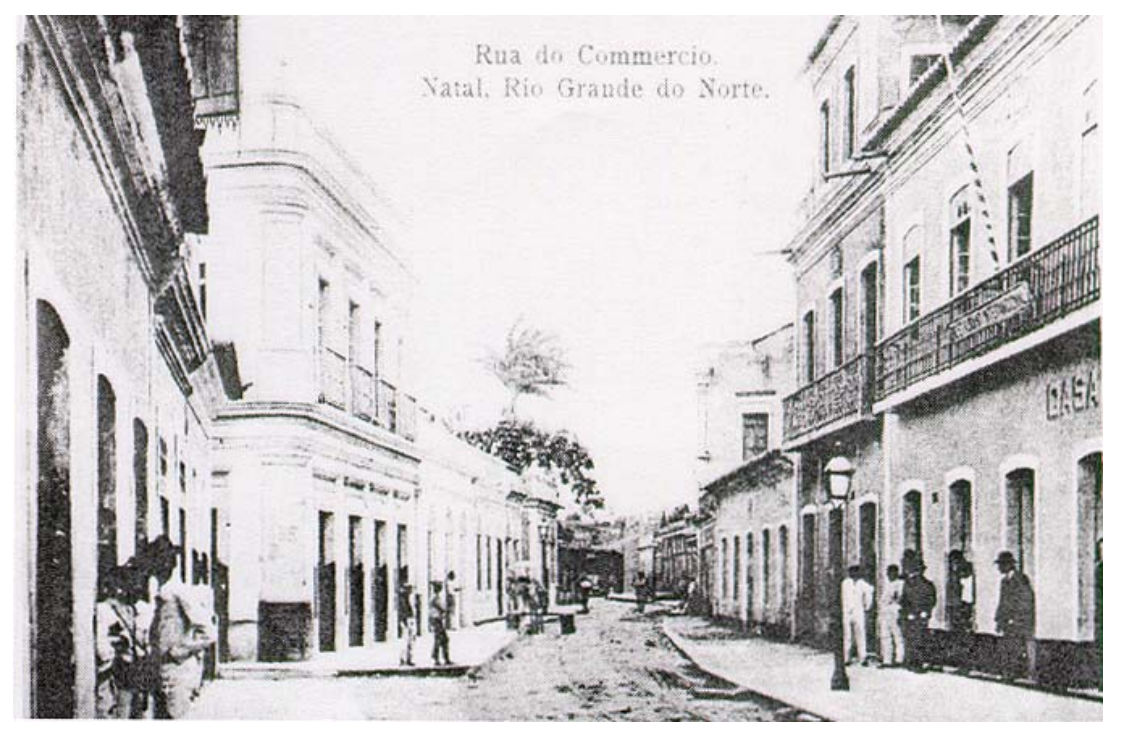

Fig. 1-16: a "civilizada" Ribeira - rua do Commercio (atual rua Chile) Fonte: Acervo Diário de Natal 


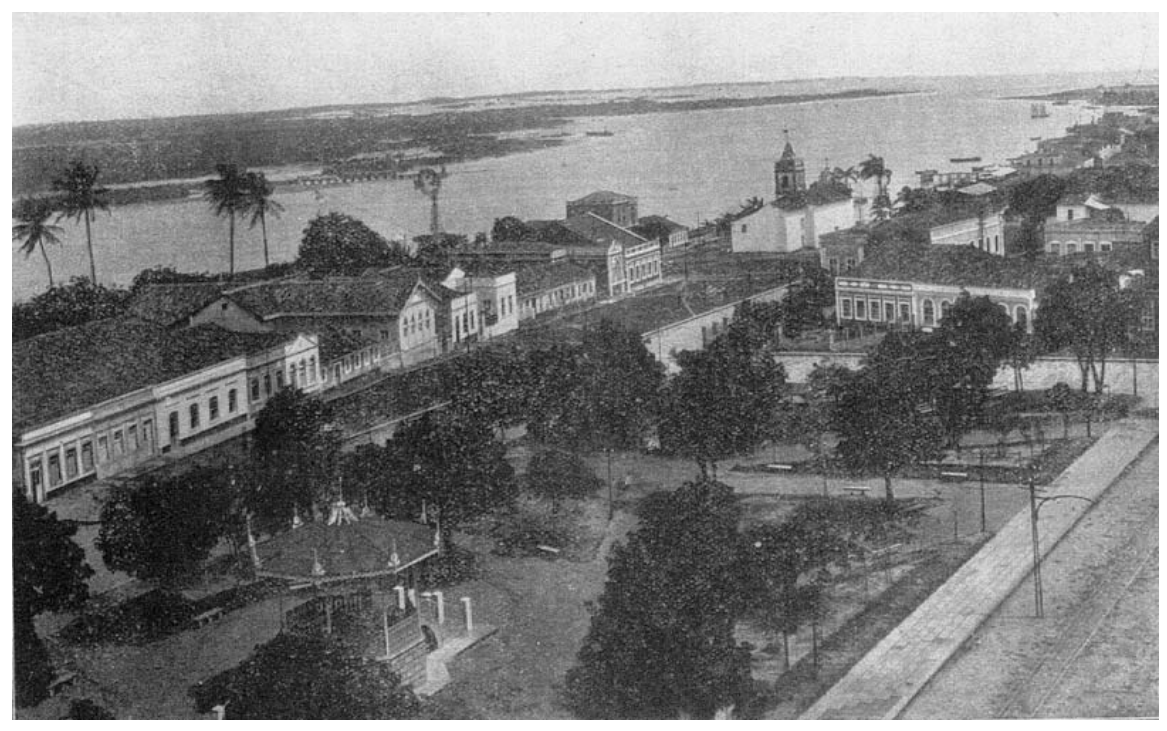

Fig. 2-01: a cidade oficial documentada pelo historiador Rocha Pombo a praça André de Albuquerque, Cidade Alta, vista do alto da torre da Matriz Fonte: Pombo, 1922.

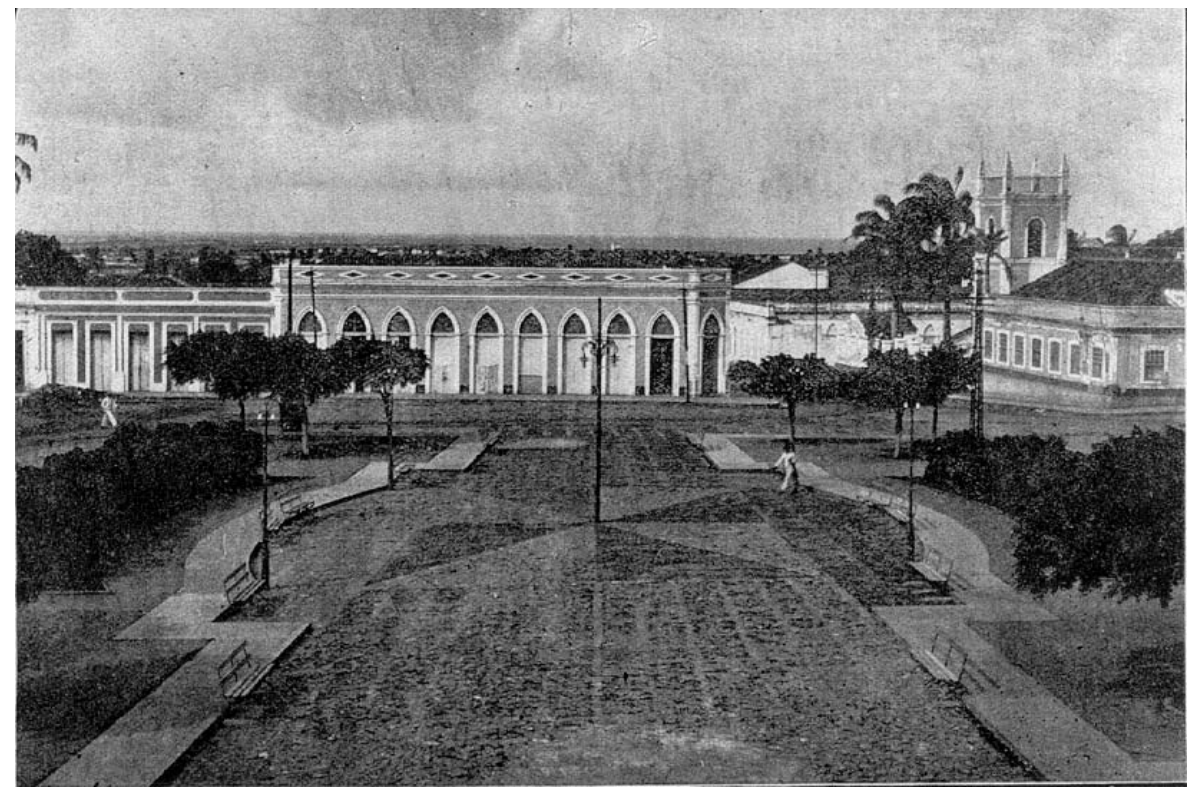

Fig. 2-02: a cidade oficial documentada pelo historiador Rocha Pombo a praça Sete de Setembro, Cidade Alta, vista a partir das escadarias do Palácio do Governo Fonte: Pombo, 1922. 


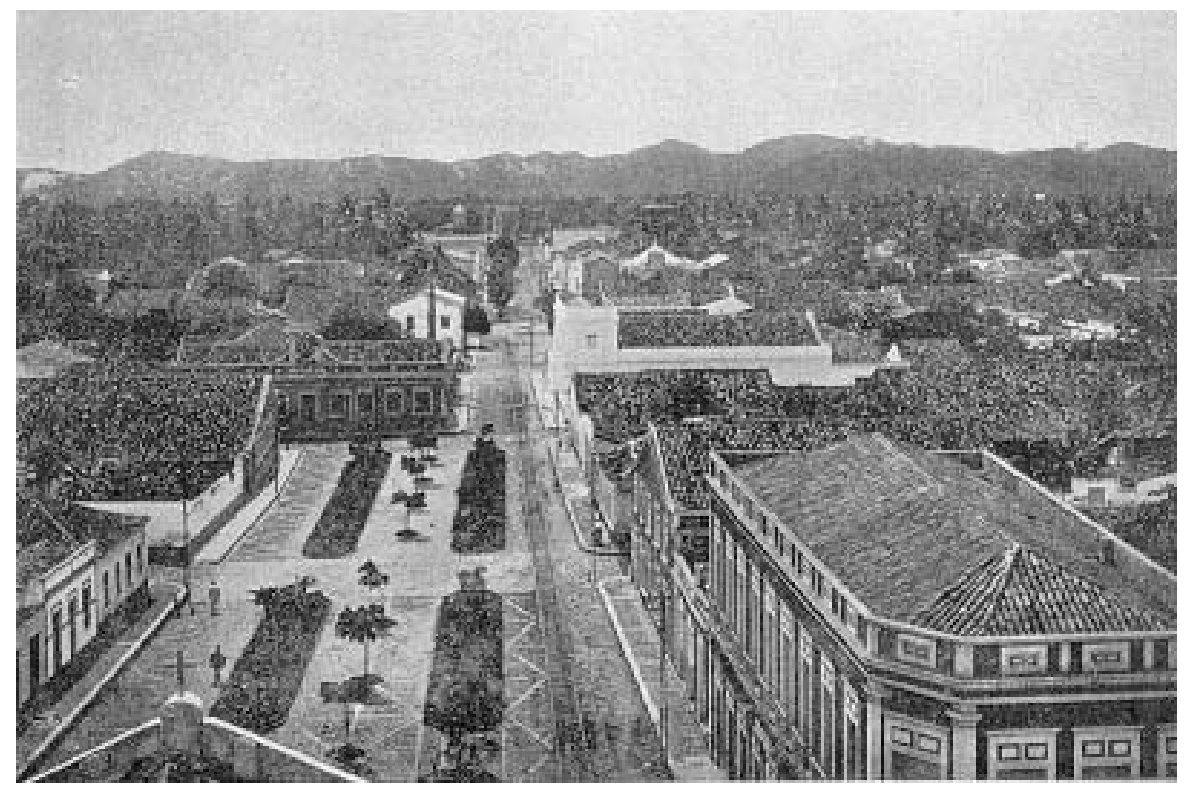

Fig. 2-03: a cidade oficial documentada pelo historiador Rocha Pombo a praça da Alegria (atual Padre João Maria) vista do alto da torre da Matriz Fonte: Pombo, 1922.

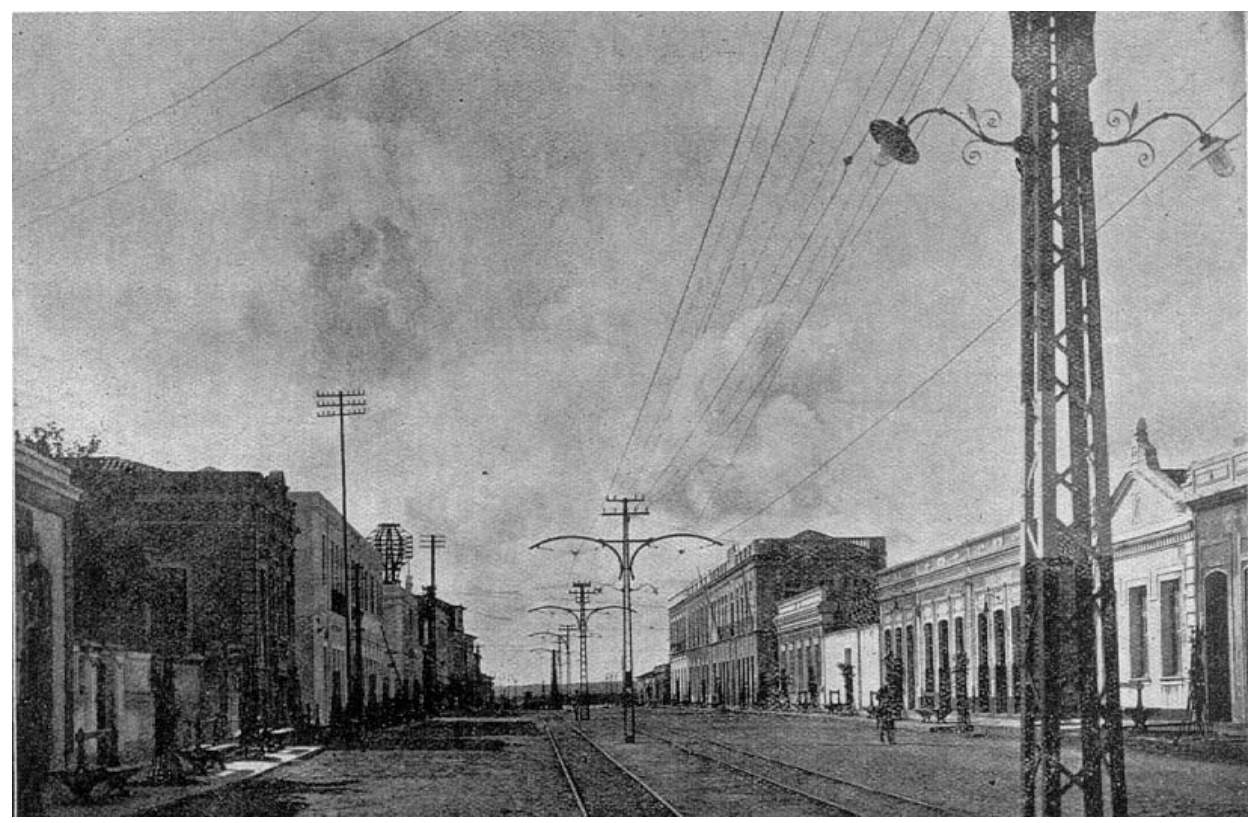

Fig. 2-04: a cidade oficial documentada pelo historiador Rocha Pombo A "chjc" Avenida Tavares de Lyra, Ribeira. Fonte: Pombo, 1922. 


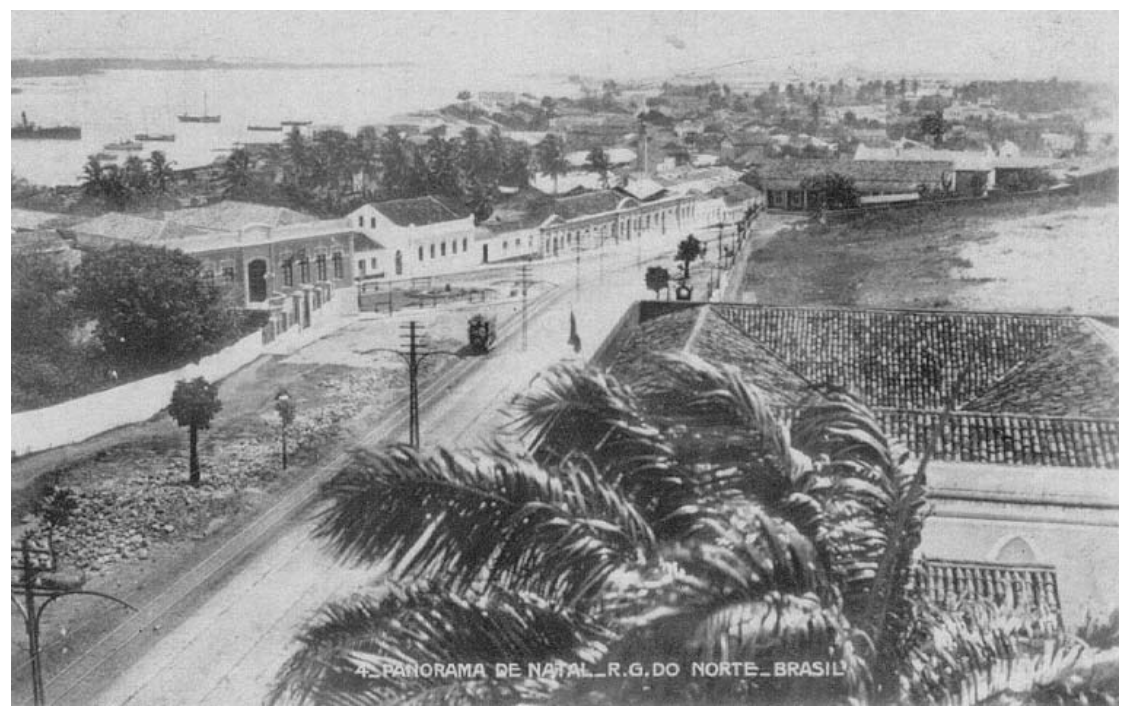

Fig. 2-05: Av. Junqueira Ayres, década de 1920

Fonte: Acervo Diário de Natal

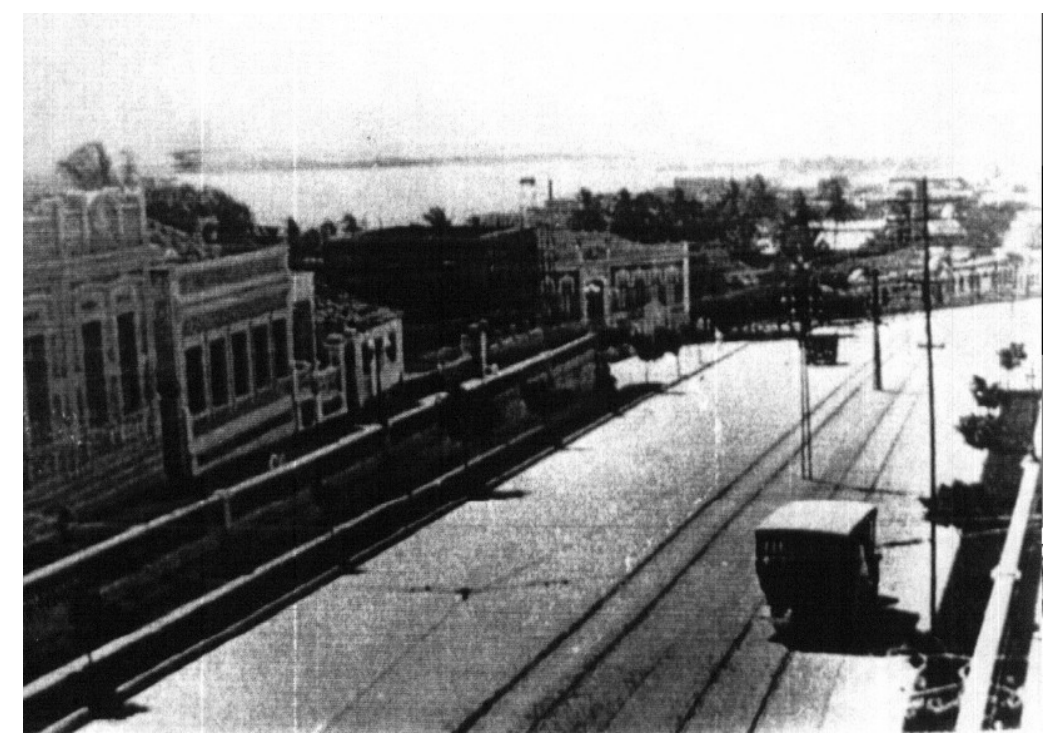

Fig. 2-06: Av. Junqueira Ayres, década de 1930 (os ônibus dividem o espaço com o bonde)

Fonte: Acervo Diário de Natal 


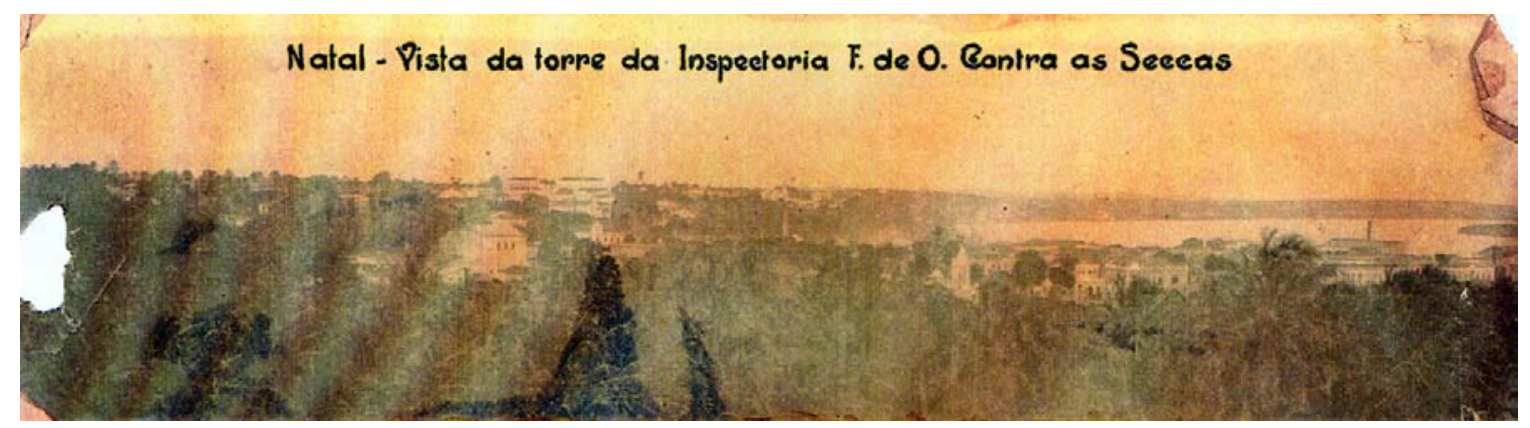

Fig. 3-01: "Natal - vista da torre da Inspectoria F. O. Contra as Seccas". Fonte: CSN, 1924.

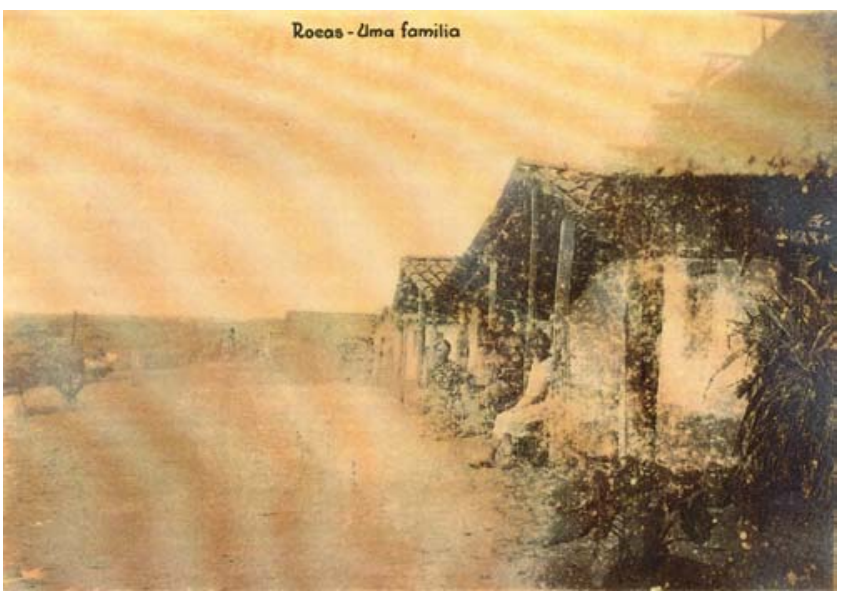

Fig. 3-02: "Rocas - Travessa Paraense". Fonte: CSN, 1924..

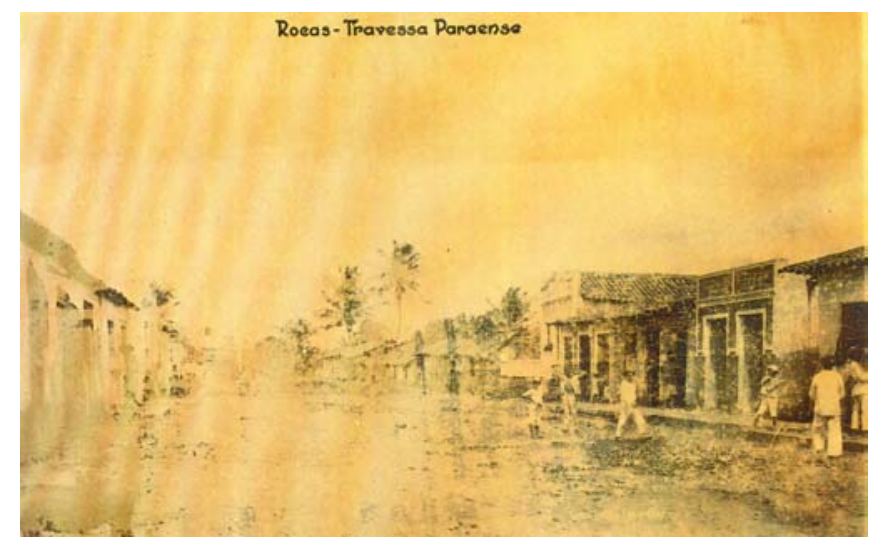

Fig. 3-03: "Rocas - uma familia"; embora muito esmaecidas, estas fotos constituem-se importantes registros das condições de habitação em bairros populares de Natal, no caso as Rocas.

Fonte: CSN, 1924. 


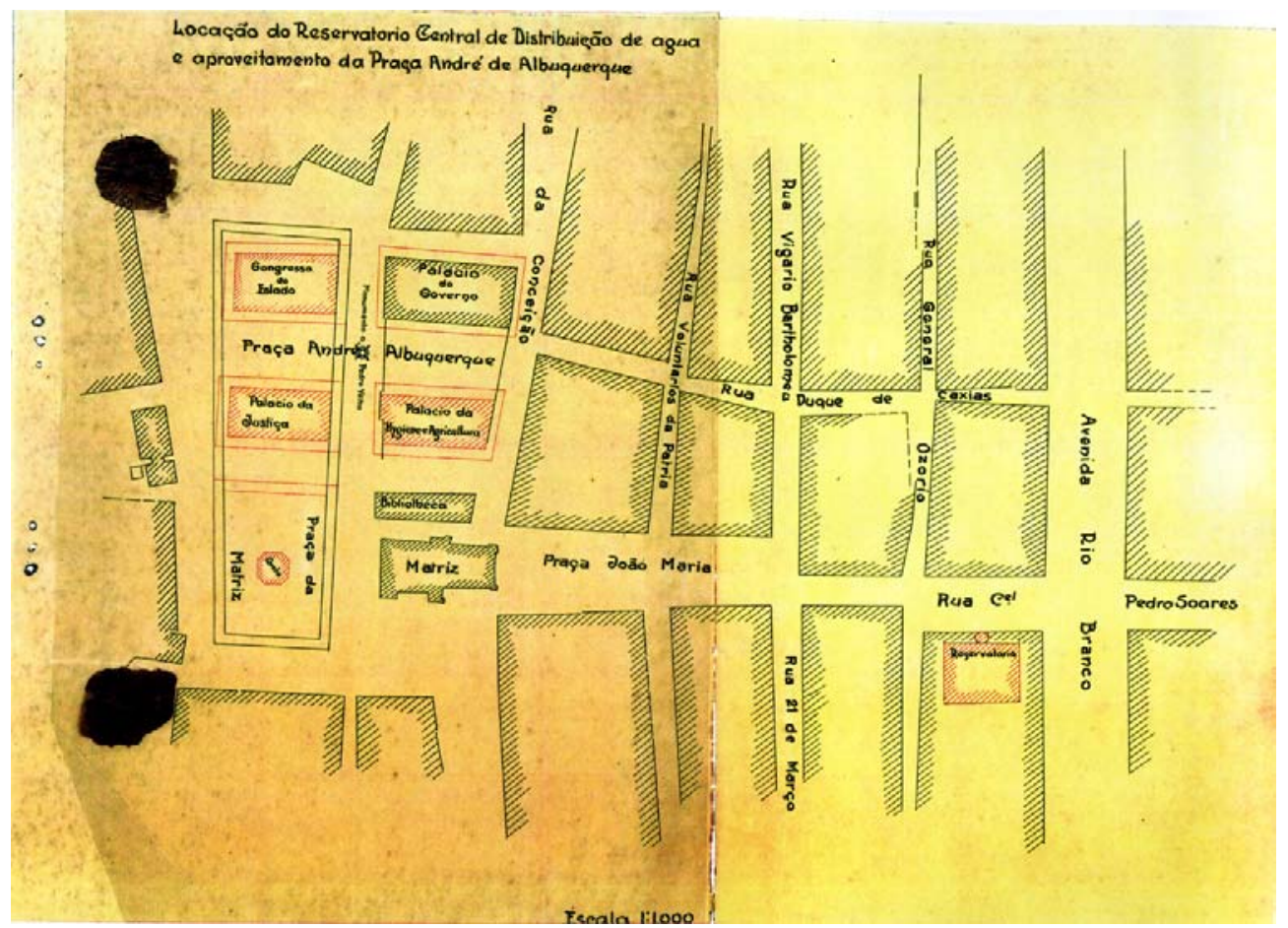

Fig. 3-04: Esboço para o projeto de intervenção no bairro da Cidade Alta, localizando os novos prédios do centro administrativo e alterando a configuração da Praça André de Albuquerque.

Fonte: CSN, 1924. 
Linhas convulsas e tortuosas retificações: transformações urbanas em Natal nos anos 1920 


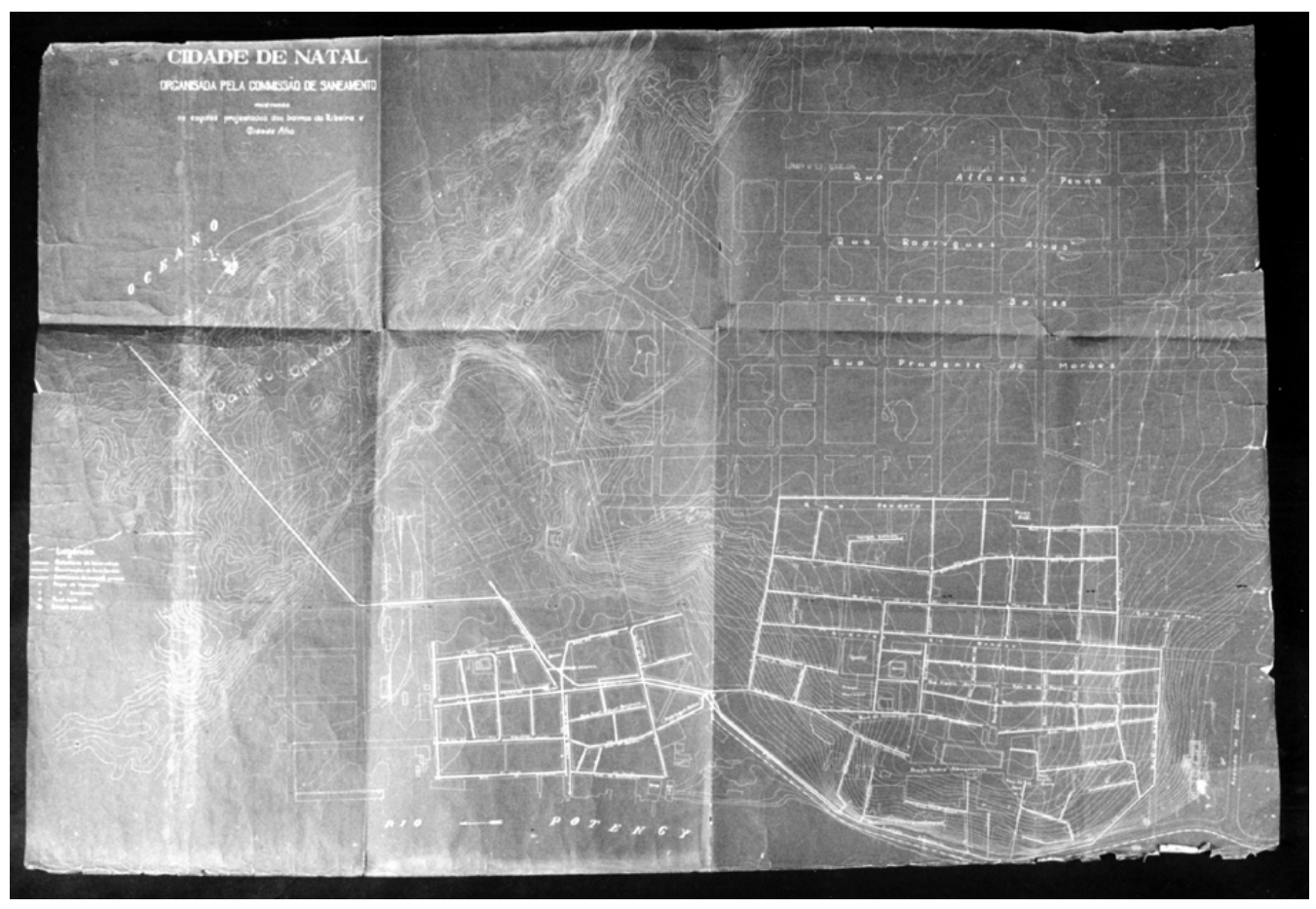

Fig. 3-05: Blueprint do projeto de saneamento da Ribeira e Cidade Alta, elaborado pelo engenheiro Henrique de Novaes em 1924

$$
\text { Fonte: Acervo Hidroesb }
$$




\section{Saneamento e educação}

No Plano Geral das Obras de Saneamento de Natal (1924) 
O ano de 1924 foi muito significativo, simbólica e materialmente, para o contexto de transformações urbanas por que a cidade de Natal passava e ainda passaria nos anos seguintes. Ano do início da administração estadual de José Augusto, cuja ênfase nos temas da educação e do saneamento já estava marcada em seu discurso de posse; de assunção do intelectual Manoel Dantas à presidência da intendência municipal de Natal, o que renovou as esperanças, pelo menos entre a elite letrada local, de acabar de vez com o "aspecto quase primitivo" da cidade, dotando-a de "grandes melhoramentos", depois de anos sem investimentos em obras públicas; ${ }^{1}$ da maior difusão e discussão nas "províncias", Natal incluída, do movimento modernista, principalmente a partir da divulgação da plaquete "A arte moderna", de Joaquim Inojosa - resenhado por Câmara Cascudo - e da carta de rompimento de Graça Aranha com a ABL; do início da profícua correspondência entre Mário de Andrade e Cascudo; enfim, do alargamento da vida cultural para além da tutela da esfera estatal em uma cidade cujo tecido social se tornava mais complexo e se politizava. ${ }^{2}$

Mais ainda, ano - se é possível delimitar com precisão o início de processos históricos - de retomada do "projeto" de modernização urbana que era articulado desde o final do século XIX. Retomada que, diga-se, como se pretende discutir neste capítulo, embora relacionada às discussões e propostas urbanísticas anteriores e ao enfrentamento do quadro de fragilidade e precariedade dos equipamentos e do fornecimento dos serviços urbanos, constituiu-se também em novas bases (discursivas e técnicas).

Nesse sentido, a criação da Comissão de Saneamento de Natal (CSN) e, principalmente, a elaboração do Plano Geral das Obras de Saneamento de Natal, realizada pela equipe técnica chefiada pelo engenheiro Henrique de Novaes ${ }^{3}$ nesse mesmo ano, podem ser considerados marcos desse processo, num momento de culminância e síntese dos debates técnicos sobre a cidade produzidos no início dos anos 1920. Mais ainda, podem ser tomados como fatos ou eventos privilegiados para discutir os vários temas que se cruzaram e se lhes articularam em torno; como um primeiro esforço de materialização dos antes difusos esforços de constituição e consecução de um projeto - agora sem aspas - de cidade moderna. Ao invés (apenas) das narrativas literárias, uma nova - outra - narrativa, extensa, sistematizada, codificada, arrogando-se neutra e racional se impôs. A cidade, pretendia-se, não seria apenas esquadrinhada, como o olhar médico faria, mas também e principalmente redesenhada, a paisagem e o traçado urbano do período colonial transformados, sob os imperativos do urbanismo moderno sanitarista.

\footnotetext{
1 "Impressões do domingo", A República, Natal, n.100, p.1, 06 maio 1924.

2 Cf. Soares, 1999, cap. 3; Araújo, M. M., 1998; Araújo, H.H, 1995, 1997.

3 Novaes nasceu em Cachoeiro do Itapemirim-ES, em 1884; formou-se em engenharia pela Escola Politécnica do Rio de Janeiro, em 1903; foi prefeito de Vitória-ES em duas ocasiões (1916-1920 e 1945), onde coordenou o plano geral da cidade (1917) e o Plano de Urbanização (1931); trabalhou ainda em cidades como São Paulo, Rio de Janeiro e Natal (Cf. Ferreira et al., 2003, anexo 4; Novaes, 1987).
} 
A emergência do saber urbanístico nesse momento, configurando o primeiro plano de fato para a cidade de Natal, com uma lógica e uma estratégia discursiva e operativa próprias, o que significava também a defesa da neutralidade e da independência frente às estruturas administrativas municipais e estaduais, acarretou uma série de implicações para a conformação do espaço urbano em transformação e para a forma de olhar, nomear e descrever esse próprio espaço. Implicações que dizem respeito tanto à formação do urbanismo como uma disciplina autônoma, às suas formulações, práticas e representações, quanto às discussões e propostas pré-existentes, aos anseios de construção de uma cidade moderna que se exprimiam em Natal, assim como nas cidades brasileiras como um todo, desde o final do século XIX.

Inscrito no horizonte dos debates mais eminentemente técnicos, assim como políticos e culturais, produzidos na cidade, o plano elaborado pela equipe chefiada por Novaes permite-nos discutir e entender, portanto, a retomada do projeto de modernização urbana para Natal - objetivo central deste capítulo. Para tanto, faz-se necessário expor, ainda que brevemente, os esforços empreendidos no início da década de 1920 para minorar o quadro de precariedade dos serviços e equipamentos urbanos; a "pauta modernizadora" e a estrita relação entre educação e saneamento da administração estadual de José Augusto, responsável direto pelo convite a Henrique de Novaes para chefiar a CSN e elaborar um plano para a cidade; e as formulações do urbanismo sanitarista e sua influência na configuração do aparato e da paisagem urbana modernos das cidades brasileiras.

\section{Esforços de superação da "crise" urbana: 1920-1923}

Como apontado no capítulo I, as discussões e as representações de "crise" surgidas no contexto do quadro de precariedade e fragilidade dos equipamentos e serviços urbanos marcaram decisivamente a virada para a década de 1920 em Natal, conformando um ambiente de insatisfação, inquietação e pessimismo ante tal realidade. $\mathrm{O}$ ano de 1920 talvez tenha sido o auge desse quadro, se considerarmos os relatos oficiais da própria administração estadual.

A insuficiência de recursos impedira a construção de qualquer obra, lamentava-se o governador Antônio de Mello e Souza, limitando-se a seção de obras públicas aos reparos inadiáveis, como a reconstrução do muro do orfanato João Maria, do da Casa de Detenção, a conservação de algumas calhas de escoamento das águas pluviais e do motor do hospital Juvino Barreto, por exemplo. Obras de melhoramento e embelezamento estavam, reconheciase, fora da pauta orçamentária. Para agravar a situação, os serviços urbanos, a cargo da ETFL, "alem de defficientes, [eram] também onerosos". Frente ao não cumprimento das exigências contratuais, do não atendimento aos prazos para melhoria dos serviços, o governo estadual decidiu rescindir o contrato de cessão dos direitos de exploração dos serviços urbanos e penhorar os bens e as rendas da empresa para pagamento das multas. Com o abandono da direção da ETFL antes da execução judicial, a administração se viu obrigada a providenciar, às pressas, condições para o funcionamento mínimo dos serviços de abastecimento de água, de iluminação elétrica e do transporte coletivo, com os bondes elétricos. ${ }^{4}$

Deve ter causado impressão tal fato. Ficar sem energia, sem água corrente, sem o bonde, sem a "alma da cidade", significava, pode-se especular, voltar à condição de atraso e ignorância, de isolamento e retraimento social, sem a possibilidade do usufruto dos "espaços elegantes" à noite, do teatro, do cinematógrafo, das vitrolas. Voltava-se à (falta de) condição do período pré-republicano que as elites pretendiam superado, sujeitas ao abastecimento precário das fontes do período colonial, aos riscos dos "miasmas" e das águas estagnadas, ao perigo das noites escuras, aos deslocamentos a pé ou no lombo de animais que constrangiam a

${ }^{4}$ Mello e Souza (Mensagem de Governo do RN), 1920, p.37, 39-41. 
possibilidade de crescimento da cidade e não coadunavam com a imagem de modernidade dos automóveis e do bonde elétrico.

A insistência nas chamadas práticas abusivas, como a lavagem de roupas nos logradouros e fontes públicas, como o Baldo, ${ }^{5}$ parecem, à primeira vista, fundamentar ou justificar esse sentimento de retrocesso ou as representações de "crise" que se tornavam mais agudas. Por outro lado, tal insistência, mesmo depois de anos de repressão das autoridades policiais e sanitárias, pode ser reveladora da situação em que vivia parte significativa da população de Natal, distante ou sem condições (financeiras) de acesso ao aparato técnico da cidade moderna em formação. As estratégias de sobrevivência, como a lavagem de roupas, baseavam-se ainda no uso tradicional dos espaços da cidade. O que deve, no mínimo, servirnos para relativizar e para entender o lugar (social, cultural) das formulações sobre a "crise" da cidade.

As crescentes dificuldades financeiras do estado e do município impediam, justificava-se, o pleno restabelecimento do fornecimento dos serviços; o tráfego dos bondes era cada vez mais irregular e, por vezes, nem mesmo acontecia. Ao longo de 1921, o governo estadual tentou, sem sucesso, a contratação de uma nova empresa concessionária (para os serviços urbanos de viação, iluminação pública e particular, telefonia, abastecimento d'água, remoção de lixo, drenagem das águas pluviais e fábrica de gelo) por meio dos reiterados editais de concorrência pública. Por fim, decidiu abrir um crédito extraordinário de 600 contos de réis por meio do decreto n. ${ }^{\circ} 150$, de 8 de setembro de 1921, encaminhado ad referendum do congresso legislativo, com o intuito de viabilizar a operação dos serviços básicos por parte da administração pública, reparando a maquinaria da usina elétrica e adquirindo o material necessário - fios de transmissão de energia, dormentes, motores e carros novos - à normalização do tráfego dos bondes. ${ }^{6}$

Essa decisão foi secundada pelo relatório produzido pela comissão técnica - da qual fez parte o engenheiro Henrique de Novaes - convocada para avaliar as condições dos serviços urbanos, em especial as da usina elétrica do Oitizeiro, em novembro de 1921. De forma significativa, as conclusões do relatório, cujos trechos principais foram publicados no jornal A República, produziram, como discutido no capítulo I, uma das sínteses mais contundentes desse período - e desse conjunto de representações: “... ou a cidade melhora os seus serviços, [...] ou a cidade morre ..."?

A constatação técnica da precariedade serviu, ao definir prioridades, pelo menos para direcionar melhor os esforços e os poucos recursos disponíveis. Mesmo assim, o processo era muito lento e estava sujeito aos "embaraços de toda especie, entre os quaes o da falta de recursos não é o mais incommodo", o que impedia a administração e o seu corpo técnico de atender a "paciente expectativa" dos natalenses. Dentre esses embaraços, os principais eram atribuídos às dificuldades de importação, aos atrasos na entrega dos materiais adquiridos - as peças de reposição dos motores, os carros novos, os fios de cobre da rede de suspensão dos bondes -, ou mesmo o desinteresse das grandes fábricas em atender solicitações de pouca monta como as que eram necessárias para Natal. ${ }^{8}$

Os relatos esparsos ou a falta daqueles que esta pesquisa não conseguiu ter acesso ${ }^{9}$ não nos permitem acompanhar as minudências dos esforços pela superação da "crise" urbana instaurada da cidade; deste modo, sabe-se que apenas em setembro de 1923 o tráfego dos

\footnotetext{
5 “O dr. Inpector de hygiene, acompanhado do medico auxiliar desssa repartição, esteve hoje pela manhã, no 'Baldo', tendo prohibido, a bem da saúde pública, a lavagem de roupa n'aquelle lograoduro público, [...]. resolveram que alli permanecesse de plantão, diariamente, uma praça, afim de evitar a continuação dos abuzoz verificados" ("Pela Hygiene", A República, Natal, n.51, p.1, 04 março 1920).

6 "Editais", A República, Natal, n.145, p.2, 08 jul. 1921; Mello e Souza (Mensagem de Governo do RN), 1921, p.32-33.

7 Dantas, 1921, p.01.

${ }^{8}$ Mello e Souza (Mensagem de Governo do RN), 1922, p.46-47.

${ }^{9}$ Como o acervo do jornal A Imprensa na década de 1920.
} 
bondes foi finalmente regularizado, ainda assim para o principal circuito (Alecrim-PetrópolisTirol-Cidade Alta). Tal fato só se tornou possível depois da criação, nesse mesmo ano, da Repartição de Serviços Urbanos (RSU), vinculada diretamente à secretaria do tesouro estadual e dirigida pelo engenheiro mecânico e eletricista Ulisses Carneiro Leão. Contudo, e apesar dos mais de 400 contos de réis despendidos apenas no reaparelhamento dos carros, o restabelecimento pleno dos serviços ainda estava distante no horizonte e dependia da expansão da capacidade de fornecimento da energia que, com poucas alterações, ainda era a mesma de $1911 .{ }^{10}$

Para além dos esforços de reorganização dos serviços urbanos, o enfrentamento do frágil estado sanitário da capital talvez tenha sido o tema que mais demandou atenção por parte da administração pública nesse período. No mesmo ano em que o médico Januário Cicco publicou o seu livro "Como se hygienizaria Natal", o governo estadual apontava a necessidade de reformar, física e administrativamente, a Inspetoria de Higiene, cuja situação de precariedade era atestada por muitos. As duas salas instaladas no andar térreo do Palácio do Governo não dispunham ainda dos aparelhos de desinfecção, nem de espaço para os exames ou para vacinação. Ademais, com poucos funcionários, a noção mais abrangente de higiene pública defendida nos documentos oficias - que incluía a ação corretiva, educacional e ostensiva "para levar o asseio a todos os recantos e o conselho a todos os domicílios" - se tornava inexeqüível: "com o que temos por ora é impossível fazer alguma coisa que com isso se pareça".

Com isso, os altos índices de mortalidade, sobremaneira infantil, se sucediam, configurando uma "verdadeira calamidade", diria o governador Mello e Souza, em 1923. O inimigo à saúde da população e do próprio corpo urbano, tornava-se cada vez mais claro, não era externo, como já havia afirmado o próprio Januário Cicco, não irromperia nos portos ou nas estações (apesar da memória recente da devastação da influeña em 1918), mas espraiava-se nas más condições de vida, de habitação e de trabalho da maioria da população de Natal, na sua má alimentação e nos seus vícios, "causas principaes da hereditariedade mórbida". Inimigo que, diga-se, não se conhecia por inteiro: com assistência médica deficiente, 555 dos 963 óbitos registrados entre janeiro e novembro de 1923, por exemplo, ocorreram por "causas não determinadas ou mal definidas". A propósito, o alto índice de óbitos consignados sem qualquer assistência médica apenas atestava as conseqüências das limitadas possibilidades de ação da Inspetoria. Em 1919, por exemplo, dos 861 falecimentos, mais da metade, 434, foram consignados sem assistência; entre outubro de 1920 e setembro de 1921, 218 dos 299 óbitos infantis enquadraram-se nessa categoria. ${ }^{12}$

Com o objetivo de reverter esse quadro, o governo estadual começou, a partir de 1921, um processo de reestruturação administrativa que, centrada então nos órgãos de higiene e assistência públicas, depois, já no governo José Augusto, englobaria toda a burocracia estatal, suas secretarias e departamentos, num esforço de descentralização. $O$ primeiro passo foi a instituição de um novo regulamento para a Inspetoria de Higiene, que agora passaria a se denominar "Directoria Geral de Hygiene e Saúde Publica", segundo o Decreto n. 148, de 1 de setembro de 1921. Subordinado diretamente ao Governo Estadual e com jurisdição em todo o território do Rio Grande do Norte, o novo regulamento da Directoria reafirmava preceitos contidos nas normativas anteriores e, mais importante, ampliava a esfera de atuação do órgão sobre a vida privada, permitindo a fiscalização desimpedida das habitações, prédios comerciais

\footnotetext{
10 “Trafego urbano", A República, Natal, n.208, p.1, 13 set. 1923; Mello e Souza (Mensagem de Governo do RN), 1923, p.4549; houve um incremento significativo nos recursos estaduais destinados aos "serviços urbanos": de apenas 70 contos de réis, em 1920, para 384, em 1922, 1.314, em 1922, e 1.235 contos de réis, em 1923 (Cf. Medeiros, J.A.B., Mensagem de Governo do RN, 1924, p.59-61).

11 Mello e Souza (Mensagem de Governo do RN), 1920, p.19-20.

12 Idem, 1920, p.19-20; 1921, p.15-17; 1922, p.27-28; 1923.
} 
e de serviços, ${ }^{13}$ especificando as situações que eram de sua competência e sistematizando a forma de enfrentar as epidemias e endemias - o que tinha uma relação direta com as formas de uso da casa e da rua.

Ampliava, da mesma forma, a abrangência de atuação sobre o espaço urbano, impondo normas - e punições quando do seu não cumprimento - para construções e reconstruções, para as habitações coletivas, para a limpeza pública, para o funcionamento de estábulos, estrebarias, matadouros, para as formas de enterramentos, exumações e cremações, etc.

Reorganizou-se ainda o serviço demográfico-sanitário, instrumento considerado essencial para mapear e esquadrinhar a situação sanitária da cidade; em 1921 também, foi inaugurado o posto de profilaxia rural do Alecrim e nomeados o novo Diretor da Diretoria Geral de Higiene e Saúde Pública e o novo Inspetor de Higiene; a publicação, a cargo da Comissão de Profilaxia, das normas federais para o saneamento predial e para o combate ao impaludismo (malária) endêmico em Natal teve grande ênfase em 1922; as primeiras por tornar obrigatório e tentar popularizar a introdução das "instalações higiênicas adequadas" nas construções de prédios urbanos - como o vaso sanitário, os sifões e as tubulações para as redes de esgoto ou para as fossas sépticas; as normas contra o impaludismo, por sua vez, poderiam ter grande impacto na conformação do território da cidade, com as previsões de retificação dos cursos d'água, de aterro ou drenagem das áreas alagáveis, de abertura de valas e canais para o escoamento das águas ou mesmo de derrubada de matas nas chamadas "zonas palúdicas". ${ }^{14}$

Por fim, deve-se chamar a atenção, nesta seqüência de proposições estatais que tinham como eixo a busca pela "salubridade urbana", para a publicação, em 1923, do regulamento para inspeção médica escolar no Rio Grande do Norte (incluindo a preparação dos professores para ensinar aos alunos preceitos sobre a higiene corporal, das habitações e das escolas). ${ }^{15}$ Cada vez mais se reiterava um vínculo estrito entre higiene e educação, entre o ambiente saudável, natural e construído, e a possibilidade de desenvolvimento físico, intelectual e moral dos indivíduos. Como já se afirmou, a "gravidade da questão sanitária no país reforçava o poder persuasivo da propaganda educacional" ${ }^{16}$ - relação, ou metáfora, que seria levada a cabo no governo de José Augusto.

Mesmo assim, a situação do quadro sanitário de Natal pouco se alterou nesse período. Apesar da deficiente estatística demográfico-sanitária, não era difícil identificar uma das principais causas dos altos índices de mortalidade: as chamadas "molestias do apparelho digestivo", produzidas pela ancilostomose e as verminoses em geral, doenças ligadas diretamente às condições precárias de saneamento. Das 903 pessoas que faleceram entre 1 de outubro de 1923 e 30 de junho de 1924, em Natal, mais de 43 \%, ou 392 pessoas, deveu-se a esse tipo de doença. ${ }^{17}$

Apesar de todos os esforços, concluia-se que, "sem exgottos e sem abundancia d'agua, muito pouco ou nada se poderá fazer em materia de hygiene". ${ }^{18}$ Só haveria solução possível, afirmava-se, com um sistema estruturado e eficiente de abastecimento d'água e de esgotamento sanitário, base técnica complementar à educação necessária da população em hábitos modernos de higiene corporal e da habitação.

\footnotetext{
${ }^{13}$ Cf. as atribuições do fiscal de hygiene (Cap. II, Art. 8, parág. 1 ao 14, do Regulamento do Serviço Sanitário do Estado do RN, Decreto n. 148, de 1 de setembro de 1921) ou "da Polícia Sanitária" (Cap. IV, Art. 156 ao 172, op. cit.).

${ }^{14}$ Cf. "Comissão de Saneamento e Prophylaxia rural", A República, Natal, n.105, p.1, 13 maio 1922; "O impaludismo em Natal”, A República, Natal, n.179, p.1, 13 ago. 1922.

15 "Regulamento para inspecção medica escolar no Rio Grande do Norte", A República, Natal, n.113, p.1, 20 maio 1923.

${ }^{16}$ Carvalho, M., 1997, p.124.

${ }_{17}$ Medeiros, J.A.B. (Mensagem de Governo do RN), 1924, p.27-28.

18 Mello e Souza (Mensagem de Governo do RN), 1923, p.30-32.
} 


\section{A "pauta modernizadora" do governo José Augusto}

Como foi visto, a ênfase na necessidade da construção das redes de saneamento, do esgotamento sanitário em particular, já aparecia nas formulações sobre a cidade desde o final do século XIX. Contudo, se, por vezes, esta ênfase serviu apenas como peça de retórica nos discursos "progressistas", sem o vislumbre da sua materialização, agora, nos anos 1920 em Natal, seria tomada como condição imprescindível para a consecução do projeto de modernização urbana (e social e econômica) que se reestruturava.

A administração estadual de José Augusto Bezerra de Medeiros, que tomou posse em 1 de janeiro de 1924, foi crucial nesse processo. ${ }^{19}$ Pode-se perguntar se independente dele, da figura política e intelectual de José Augusto, esse processo não teria sido encaminhado de alguma outra forma, tendo em vista o acúmulo de discussões sobre o saneamento da cidade, as proposições técnicas, como as do médico Cicco, ou mesmo os esforços empreendidos na administração anterior para reverter o quadro de "crise" urbana. Questionamento válido, quando se pensa no papel do "ator social", na contribuição dos itinerários individuais ao meio cultural de uma época, às relações econômicas mais estruturais, por exemplo. ${ }^{20}$

Embora não seja objetivo desta pesquisa analisar a contribuição individual de José Augusto - estudo já empreendido com propriedade, por sinal ${ }^{21}-$, não se pode negar que a sua ação foi decisiva para viabilizar, e intensificar, o processo de modernização. Ação mediada tanto pelos interesses econômicos do grupo político do qual fazia parte quanto pelas representações sobre progresso e civilização do ambiente intelectual que lhe formou e, depois, ajudou a construir e a disseminar. Nessas representações, os temas da educação e do saneamento foram tomados como os eixos centrais para construir um (novo) projeto de modernidade, para civilizar o estado, sua capital e, principalmente, seu povo. ${ }^{22}$

Destarte, deve-se lembrar que esses temas não eram vistos dissociados; ao contrário, a noção de saneamento seria discutida, amiúde, para além das redes técnicas, como uma metáfora da regeneração do corpo nacional, cujo instrumento principal seria a educação. Para Belisário Penna, por exemplo, um dos fundadores da "Liga Pró Saneamento do Brasil" e "entusiasta pela educação", a exemplo de José Augusto, o vínculo entre a salubridade da cidade, a moral da sociedade e o progresso do país era condição irrefutável. A higiene não mais revestiria um projeto repressor e nem o saneamento do país era apenas uma tarefa técnica, de construção de redes de esgoto e abastecimento d'água, mas principalmente de "saneamento physico, moral e intellectual dos seus habitantes". A "proverbial e decantada" indolência do brasileiro não se devia ao clima tropical ou ao caldeamento racial, afirmava, mas à doença, à ignorância e ao vício de alimentação. Como se formar como nação, se boa parte de sua população, como a sertaneja, vivia abjetamente "em ranchos de palha ou de taipa, inçados de barbeiros, de percevejos e de piolhos, dormindo promiscuamente paes e filhos em giráos de páos roliços, sobre enxergas de palhas de burity, sem noção de asseio rudimentar, sem utensilios dos mais comezinhos, [...], alimentando-se deficientemente, innumeros delles apenas com raizes, peixe, farinha e caça.", perguntava-se Penna. O saneamento do Brasil era antes de

\footnotetext{
${ }^{19}$ Deve-se lembrar que a ascensão de José Augusto ao governo do RN significou também o deslocamento definitivo, na Primeira República, da ênfase econômica das atividades produtivas do estado do litoral açucareiro para o sertão agropecuário, produtor de algodão, novo motor da economia nordestina e potiguar, em especial (Cf. Araújo, 1998; Clementino, 1986). ${ }^{20}$ Cf. Salgueiro, 1997, p.13-21.

${ }^{21}$ Aqui me refiro, em especial, ao livro da professora Marta Araújo (1998); embora não trabalhe com o conceito de "biografia intelectual" - como o discute Heliana Salgueiro (op. cit.) -, Araújo aponta as relações entre o tema da educação e as reformas administrativas e urbanas empreendidas a partir de 1924, discussão mediada pelas representações culturais e pela formação de José Augusto.

22 José Augusto esteve associado à criação da Liga de Ensino do Rio Grande do Norte, em 1911, e à da Escola Doméstica, em 1914; alguns dos principais trabalhos na área de história da educação, como os de Jorge Nagle e Vanilda Paiva, destacam o papel de José Augusto como um dos principais políticos nacionais a exprimir o ideal de reforma educacional no Brasil: participou ativamente da campanha de alfabetização (1915-23), como presidente da comissão de instrução pública da Câmara Federal, e da criação da ABE em 1924 (associação na qual seria presidente décadas depois, em 1943, 1957 e 1960-61); além de ter publicado "Pela Educação Nacional" (1918) e "Eduquemo-nos" (1922), esteve vinculado às publicações da Revista Educação (1922-24) e da Revista Brasileira de Educação (1929) (Cf. Araújo, M., 1998).
} 
mais nada um problema de educação e organização social do país - que não havia sido contemplada pela "comédia democrática" da República - e que exigia a fixação do homem no campo, evitando o congestionamento das cidades e o abandono das áreas rurais. ${ }^{23}$

Não é à toa que citamos as formulações de Penna. Não só porque esteve em Natal em 1924 e 1927 divulgando suas idéias; mas pela proximidade de temas e preocupações de um ambiente intelectual comum a José Augusto. Distante das imprecações "antioligárquicas" e anti-republicanas - ou, pelo menos, contra o modo como a República se fazia no Brasil - dos tempos de estudante de Direito na Faculdade do Recife, no início do século XX, José Augusto se aproximou cada vez mais da discussão da renovação da nação por meio de uma "educação integral" e se tornou uma das suas principais vozes. Educação para os tempos modernos, afirmava-se: a contraparte necessária para viver em um novo meio, saneado, de regras claras de trabalho e de higiene individual e coletiva. ${ }^{24}$

O que, no governo José Augusto, buscar-se-ia concretizar por meio das reformas: do aparelho burocrático do estado nos "moldes da fábrica moderna" - com a criação de departamentos decentralizados, como o de Saúde Pública, de Educação e de Agricultura e Obras Públicas; da instrução pública baseada no ideário escolanovista; ${ }^{25}$ e, principalmente, por meio da reforma urbana da cidade.

Em 1924, as ações se intensificaram nesse sentido. A Diretoria de Higiene recrudesceu a sua ação, marcada pela análise de que "a defesa sanitária de Natal está por fazer"; submeteu, segundo o Regulamento do Serviço Sanitário, a cessão de licenças para construção e reformas prediais ao das autoridades sanitárias constituídas, que tinham o poder de suspender as obras irregulares e multar os infratores, ${ }^{26}$ iniciou campanha e ações contra o uso incorreto das redes de coleta de águas pluviais que, na Ribeira, estavam sendo utilizadas para o despejo das águas servidas, do lixo e dos resíduos sólidos, que comprometiam a drenagem do bairro e, conseqüentemente, deixava-o novamente à mercê das inundações:

\begin{abstract}
"Da ligeira inspeção procedida em estabelecimentos comerciaes, hotéis e restaurantes, casas particulares, etc., verificou-se que poucos possuem fossas para coleta de águas servidas e materiais fecaes. Muitos destes detritos foram, criminosa ou abusivamente, canalizado para o exgotto de águas pluviaes, infeccionando as galerias, $e$, por este meio, infeccionando a cidade, outros são collectados em fossas absorventes abertas na areia, em contacto com o lençol d'água permanente, sem nenhuma condição de asepcia". ${ }^{27}$
\end{abstract}

Com uma atuação muito limitada da Intendência Municipal, ${ }^{28}$ a Diretoria de Higiene assumiria cada vez mais a responsabilidade para normatizar e fiscalizar o uso e a ocupação do solo em Natal, afirmando a cientificidade e a importância do rigor das medidas sanitárias que, defendia-se, "devem ser levadas até o fim, sem que interesses particulares prejudiquem sua eficácia". ${ }^{29}$

Dentre as muitas proposições a ações, é importante registrar: a proibição da construção de estábulos e estrebarias na "zona urbana central", evitando assim mais um uso que trazia consigo a proliferação de moscas, "transmissoras de tantas doenças, que encontram nas estrumeiras as mais favoráveis condições para a sua procreação e desenvolvimento"; a assunção da responsabilidade pela cessão dos direitos de exploração do serviço de limpeza

\footnotetext{
${ }^{23}$ Penna, 1918, p.07-58 passim.

${ }^{24}$ Carvalho, 1997, p.124-128.

${ }^{25}$ Cf. Araújo, M., 1998.

26 "Varias - Directoria de Hygiene", A República, Natal, n.6, p.1, 08 jan. 1924; s/t, A República, Natal, n.11, p.1, 13 jan. 1924.

${ }^{27} \mathrm{~S} / \mathrm{t}, A$ República, Natal, n.17, p.1, 20 jan. 1924; grifos nossos.

${ }^{28}$ Como será discutido no capítulo IV, a Intendência se tornaria um órgão atuante apenas a partir da administração do engenheiro Omar O'Grady.

${ }^{29} \mathrm{~S} / \mathrm{t}$, A República, Natal, n.18, p.1, 22 jan. 1924.
} 
pública, antes a cargo do Tesouro estadual; a exigência do "habite-se" e a publicação das normas para a sua verificação e cessão; a regulamentação sobre o uso, formato e materiais adequados para a construção de fossas sépticas - para as áreas da cidade que não seriam atendidas a princípio pelo projeto de esgotamento sanitário do plano elaborado por Novaes; e a proibição da construção de casas geminadas. ${ }^{30}$

A reforma administrativa, implementada pelo governo estadual em junho de 1924, com a criação de departamentos - termo muito utilizado pelo sistema de organização da indústria moderna ${ }^{31}$ - que, a princípio, atuariam de forma mais autônoma (embora coordenados pela Secretaria Geral), não alterou o ritmo das atividades dos órgãos de higiene pública. A propósito, não se deve esquecer que autonomia de ação era uma prerrogativa defendida pelos profissionais que dirigiam esses órgãos.

Nesse aspecto, não houve alteração de fato no perfil de atuação do, agora, Departamento de Saúde Pública. Em julho desse mesmo ano, por exemplo, resolveu dividir a cidade em zonas para facilitar os trabalhos de inspeção e recenseamentos. Zoneamento ainda incipiente, mas que estabelecia instrumentos mínimos para o controle do espaço urbano; a proposta compreendia uma "zona urbana central" (Cidade Alta e Ribeira, da rua Silva Jardim ao córrego que passava do Baldo até o Oitizeiro e da avenida Deodoro e da rua São José até o rio Potengi), uma "zona urbana periférica" (Tirol, Petrópolis e Alecrim, até a avenida Alexandrino de Alencar) e a "zona suburbana" (Areia Preta, Rocas, Alto da Bandeira e demais localidades), além da "zona rural". Ainda estabeleceu as proibições e punições aos que sujavam as vias públicas, com "lixo, cascas de fructas, papeis, etc.", principalmente na zona urbana central; estendeu a exigência para todo o estado de um parecer sanitário para qualquer construção ou reforma realizada; e regulamentou e obrigou o uso de depósitos de lixo em todas as habitações. ${ }^{32}$

Contudo, por mais rigorosa que fossem as normativas e por mais eficaz que fosse a atuação do departamento e de seus profissionais e funcionários, afirmava-se que sem a construção das redes técnicas do saneamento e sem a reforma da cidade existente, de seus espaços e construções insalubres, tais medidas não teriam efeito duradouro e permaneceriam como paliativos apenas. A necessidade de um plano para a cidade colocava-se na ordem do dia uma vez mais, como o instrumento necessário para "transformar a nossa capital, dando-lhe os elementos de higiene e conforto que ela está a reclamar para que se torne um centro de atração de capitalistas e homens de negócios que aqui podem e precisam vir colaborar conosco na obra de constante progresso de nossa terra", diria o governador José Augusto ao justificar a criação da Comissão de Saneamento de Natal (CSN)..$^{33}$

Instituída por meio do Decreto n. ${ }^{\circ} 231$, de 26 de abril de 1924, a CSN tinha o objetivo expresso de:

\footnotetext{
“a) estudar, projetar, instalar e organizar todos os serviços de abastecimento d'água, esgotos domiciliares e pluviais do Município da Capital e de outros que se quiserem aproveitar do auxilio do Estado para os mesmo fins;

b) estudar e projetar a ampliação da cidade, dando os alinhamentos respectivos e fornecendo ao Tesouro do Estado e ao Município os dados técnicos para a venda e aforamento dos terrenos de propriedade do Estado ou do Município;
}

\footnotetext{
30 "Pelas Repartições - Directoria Geral de Hygiene e Saúde Pública"; $A$ República, Natal, n.31, p.1, 10 fev. 1924; S/t, $A$ República, Natal, n.77, p.1, 05 abr. 1924; "SOLICITADAS - Termo de Contracto entre a Directoria de Hygiene e o cidadão Francisco Cardozo", A República, Natal, n.115, p.2, 24 maio 1924; "Pelas Repartições - Directoria de Hygiene", A República, Natal, n.126, p.2, 06 jun. 1924; "As fossas", $A$ República, Natal, n.130, p.1, 11 jun. 1924, "Pela Hygiene”, A República, Natal, n.134, p.1, 15 jun. 1924.

31 Como lembra Araújo, M.M. (1998).

32 "Pelas Repartições - Directoria de Higiene", A República, Natal, n.148, p.1, 04 jul. 1924; "Varias", A República, Natal, n.218, p.2, 25 set. 1924; "Pelas Repartições - Departamento de Saúde Publica”, A República, Natal, n.268, p.1, 25 nov. 1924.

33 Medeiros, J.A.B. (Mensagem de Governo do RN), 1924, p.35.
} 
c) organizar o cadastro da cidade;

d) estudar e projetar as obras outras que lhe forem ordenadas pelo Governo do Estado, e requisitadas pelos municípios a critério do Governador". ${ }^{34}$

A CSN pode ser considerada, deste modo, pelo menos nos seus termos de criação, como o primeiro órgão de urbanismo da estrutura administrativa local. A normatização e as propostas de transformação do espaço da cidade não aparecem mais atreladas apenas aos imperativos da "higiene", da medicina social. Embora o discurso de José Augusto, por exemplo, ainda faça referência a temas de sabor oitocentista, como os "elementos de higiene e conforto" - constitutivos também, é certo, da formação do moderno saber urbanístico - não deixa de ser reveladora a sua preocupação para que o plano contemplasse as necessidades de circulação dos "homens de negócio". Temas caros ao discurso dos urbanistas assomaram então à esfera de debates: a circulação de pessoas e mercadorias, a necessidade de prever e determinar a forma de crescimento da cidade e, principalmente, uma abordagem que contemplasse de forma abrangente a cidade e o seu território - como suporte físico.

O plano elaborado no âmbito da CSN representou, ademais, a primeira tentativa de consubstanciação do projeto de modernização empreendido pelas elites para Natal. Para o governo de José Augusto, em particular, significou a (possibilidade de) materialização dos ideais de reformar - a cidade e os seus habitantes - por meio da educação e do saneamento; a possibilidade de construir uma cidade moderna finalmente.

Conquanto logo tenha ficado constrangido às contingências das receitas estaduais solapadas, em 1924, não por uma grande seca, mas pelas chuvas fortes e as conseqüentes inundações que danificaram as estradas de rodagem e prejudicaram a produção do sal e do algodão -, os estudos e as propostas contidas no Plano Geral das Obras de Saneamento de Natal constituíram-se num importante instrumento para as reformas e planos desenvolvidos nos anos seguintes; mais ainda, transformaram-se numa referência para o debate que se seguiu.

\section{Uma nova paisagem para Natal}

Se não se pode pensar o lugar do Plano de Saneamento 1924 para Natal fora deste movimento mais amplo e geral no qual a questão sanitária - débil em todo o país transformou-se em metáfora da condição nacional e a educação em obra de saneamento; se não se pode discuti-lo sem levar em conta as injunções políticas e econômicas que mediam os vínculos - muitas vezes determinantes para a consecução das propostas técnicas - entre os profissionais e os membros da classe dominante, ${ }^{35}$ é certo também que operou com uma lógica própria que determinou ou influenciou a forma de ler, interpretar e intervir sobre o meio natural, sobre o espaço social e histórico da cidade.

O plano não foi portanto um reflexo condicionado das discussões, dos ideais ou das representações sobre a cidade moderna; ao contrário, ou melhor, em paralelo, introduziu novos elementos nesses debates, novas representações que se amalgamaram, se sobrepuseram ou mesmo eliminaram as antigas. Produzido por uma disciplina em formação, o discurso oriundo do urbanismo tem também os seus próprios procedimentos internos de controle e de delimitação, classificando, ordenando, distribuindo, construindo a validade dos seus termos e elementos, ou mesmo excluindo aqueles que não se enquadravam em suas categorias. ${ }^{36} \mathrm{O}$

\footnotetext{
${ }^{34}$ Determinações do Decreto n. ${ }^{\circ}$ 231, de 26 de abril de 1924, que criou a Comissão de Saneamento de Natal (In Medeiros, J.A.B., Mens. Gov., 1924, p.35).

35 Topalov (1996) discute que, a despeito da imagem de neutralidade e independência que projeta sobre si mesmos, os especialistas necessitavam do vínculo privilegiado com os membros das classes dominantes para poder legitimarem-se socialmente.

36 Sobre a ordem do discurso, Cf. Foucault, 2002.
} 
plano trouxe e impôs assim uma nova forma de discutir a cidade que, nesse caso, é tributária do urbanismo sanitarista e, particularmente, da formação politécnica no Brasil.

Convidado a dirigir os estudos, os serviços e as obras que ficariam a cargo da CSN, o engenheiro Henrique de Novaes não era desconhecido ou "estrangeiro" na cidade. Conhecera Natal como engenheiro civil recém-graduado (pela Escola Politécnica do Rio de Janeiro, onde se formou, em 1903), integrante da comissão federal (antecessora da criação da Inspetoria de Obras Contra as Secas, em 1909) chefiada por Sampaio Correia enviada ao estado para estudar e combater os efeitos da seca e concluir a estrada de ferro que ligaria a cidade de Ceará-Mirim a Natal. Chegara em março de 1904, num período de convulsão social, com a cidade invadida por milhares de retirantes que esperavam o embarque para os seringais do norte ou os cafezais do sul. Em suas "reminiscências do Rio Grande do Norte", contrasta a rica descrição do Sertão às poucas palavras que designam a "minuscula" e "atrazada" cidade. ${ }^{37}$

Há uma menção de que teria feito um plano urbanístico para Mossoró-RN por volta de 1916, antes portanto do seu primeiro mandato como prefeito de Vitória-ES (maio de 1916 a janeiro de 1920), período em que coordenou o plano geral da cidade e desenvolveu os projetos arquitetônicos da Catedral Metropolitana e do Ginásio Espírito-santense. ${ }^{38}$ Em 1921 voltou ao Rio Grande do Norte para dirigir a seção local das Obras Contras as Secas, ${ }^{39}$ cargo que ocupava quando recebeu o convite, em janeiro de 1924, para estudar e projetar os melhoramentos materiais necessários "em conjunto e em detalhe", para que pudesse ser executado de forma "racional e proveitosa". 40

Dentre esses melhoramentos, que incluíam a construção e expansão da infraestrutura de circulação (as estradas de ferro e de "rodagem"), afirmava-se a prioridade da construção do sistema de abastecimento de água de Natal, "porque é o problema mais premente, do qual dependem outros que se prendem ao problema geral do desenvolvimento das forças econômicas do estado". "Assim, os esforços pela transformação da cidade em uma capital, centro do poder econômico e político de fato, justificavam-se também na necessidade de pôr termo aos "perigos" a que estavam sujeitas as aglomerações urbanas mais densas. ${ }^{42}$

A autorização para que o governo pudesse encomendar os estudos dos mananciais mais próximos e mais adequados ao abastecimento de Natal já havia sido expedida no ano anterior, ${ }^{43}$ como uma das últimas deliberações da administração de Antonio de Mello e Souza no intuito de construir as condições necessárias à superação da "crise" urbana que, reiteravase, ainda marcava o cotidiano da população. Afinal, condenadas pela leitura higienista, as antigas fontes que serviam ao abastecimento da vida urbana do período colonial, mesmo aformoseadas e vigiadas, como o Baldo, não eram mais suficientes, nem salubres, para o novo ritmo de crescimento que se pretendia imprimir à cidade.

Novaes encontrou um ambiente favorável para o desenvolvimento de seus trabalhos, sem disputas políticas e técnicas de relevo e sem impedimentos burocráticos. Assim, secundado pelos engenheiros (que formavam o corpo técnico auxiliar) José Candido Ferreira,

\footnotetext{
37 Novaes, 1987. ago. 1921).

${ }^{40} \mathrm{~S} / \mathrm{t}, A$ República, Natal, n.14, p.1, 17 jan. 1924.

${ }^{41}$ Ibid.

${ }^{42}$ Cf. Medeiros, J.A.B. (Mensagem de Governo do RN), 1924, p.35.

43 "Parte official - Actos do Poder Legislativo", A República, Natal, n.274, p.1, 05 dez. 1923.
}

${ }^{38}$ Cf. Leme, 1999, p.473-474; o registro de um plano para Mossoró consta do prefácio das memórias de Novaes (1987).

39 "Assumiu a direcção das Obras Contra as Seccas neste Estado o dr. Henrique de Novaes, portador de um nome atacado com justiça na engenharia. [...]. Tendo principiado a sua carreira no Estado sob a direcção do dr. Sampaio Correia de quem foi o mais proximo auxiliar entre nós, [...]. O dr. Henrique de Novaes projectou e construiu a obra mais notavel do Brasil em cimento armado, o grande reservatorio do Engenho de Dentro, no Rio de Janeiro e que ainda hoje é um verdadeiro modelo technico; fez a revisão dos Estudos do Engenheiro Schnoor, da Estrada de Ferro Noroeste do Brasil; realizou a exploração e organizou o projecto da Estrada de Pirapora a Belém, assim como o da cidade de Victoria, da qual foi prefeito, estudou e projectou a Estrada de Rodagem de Sta. Theresa a Sta. Leopoldina; e dirigiu a grande usina de Paineiras uma das mais perfeitas do Brasil, de producção de seis mil saccos diarios" ("Dr. Henrique de Novaes", A República, Natal, n.180, p.1, 24 
Henrique Pyles, Carneiro Leão e Paulo Coriolano, e utilizando os instrumentos de medição e prospecção da IFOCS, Novaes pôde apresentar, em junho de 1924, o orçamento definitivo para a consecução das obras projetadas, agora no âmbito das atividades da CSN. ${ }^{44}$

Chamado inicialmente para projetar o abastecimento de água de Natal, Novaes não se furtou, ao contrário, a propor um plano para a cidade existente. Revelando a sua aproximação ou filiação à - se for possível falar em - "tradição" do urbanismo sanitarista, a uma mentalidade e a um conjunto de procedimentos e pressupostos teóricos, cujo maior exemplo encontra-se nas propostas e obras de Saturnino de Brito. ${ }^{45}$ A proposta de um plano geral talvez seja o traço mais evidente dos vínculos que, de alguma maneira, uniam esses vários profissionais.

Assim, deve-se precisar que os termos do decreto que instituiu a CSN revelam muito mais essa filiação do que uma preocupação original dos administradores estaduais. Não à toa, a divulgação do primeiro relatório da CSN, assinado por Novaes, antecede a data de publicação do citado decreto. ${ }^{46} \mathrm{O}$ relatório já discute a solução, dentre as várias opções estudadas, para o abastecimento de água para Natal e para a rede de esgotos, com uma apresentação prévia dos seus respectivos orçamentos, além dos esboços para a reforma do traçado urbano da Cidade Alta e para os novos edifícios que abrigariam a administração e os equipamentos do sistema. ${ }^{47}$ Devido a não existência de um memorial justificativo do plano ou das propostas arquitetônicas, deve-se ressaltar que esse pode ser lido também por esse viés, como um documento que nos permite entrever as discussões, as representações, os pressupostos teóricos e as preocupações que o secundaram.

A exigência, ou melhor, a reivindicação da necessidade de um plano geral surgia portanto dentre do contexto do processo de constituição do urbanismo como uma disciplina autônoma; significava, ademais, demarcar um lugar preciso e exclusivo de atuação do técnico urbanista, uma esfera neutra, defendia-se, afastada das disputas políticas cotidianas; uma possibilidade de gerir os destinos da cidade e, assim, evitar o comprometimento das soluções técnicas devido ao crescimento desordenado e à sobreposição dos interesses particulares, como defenderia de forma veemente Saturnino de Brito, por exemplo. ${ }^{48}$

A elaboração do plano exigiu da equipe técnica um esforço amplo para a realização, em um tempo limitado e relativamente curto, tanto da identificação e da avaliação das possíveis novas fontes para o abastecimento d'água; do levantamento da demografia predial e populacional - os dados sobre a Ribeira e a Cidade Alta foram apresentados em detalhes, rua a rua, enquanto que os do resto da cidade ainda estavam em "via de acabamento"; principalmente, do levantamento e sistematização da planta topográfica e cadastral de Natal. A cidade, e a região circundante de influência direta, é então transformada, ou decodificada, em dados técnicos mensuráveis e, segundo a visão progressista da ciência, manipuláveis. A especulação cedia lugar à previsão exata das necessidades de abastecimento da cidade existente; em paralelo, o estudo das fontes - baseado nos levantamentos sobre a profundidade média, presença e nível dos poluentes, velocidade de descarga e seção da vazão - indicavam as possibilidades de expansão física e demográfica da cidade sem sobrecarga no sistema, por exemplo. $\mathrm{O}$ abastecimento, assim que implementado, poderia atender, de imediato, a uma população de 45.400 habitantes, considerando apenas os bairros mais populosos (Alecrim, Cidade Alta, Ribeira e Cidade Nova); fornecimento superior, portanto, a demanda instalada.

\footnotetext{
44 “Comissão de Saneamento de Natal”, A República, Natal, n.142, p.1, 17 jun. 1924; Medeiros, J.A.B. (Mensagem de Governo do RN), 1924, p.36.

45 Andrade, 1992.

${ }^{46}$ Em 04 de Abril de 1924, o Jornal A República divulgava que Henrique de Novaes havia concluído os estudos preliminares para o sistema de abastecimento de água da cidade, antes portanto da publicação do citado decreto, do dia 26 do mesmo mês. 47 Agradecemos aqui ao Sr. Edgard Dantas pelo acesso aos originais do relatório, cujas partes (folhas, anexos, telegramas, fotos e desenhos) foram fotocopiadas e digitalizadas e constam do acervo desta pesquisa.

48 Cf. Andrade, C., 1996.

${ }^{49}$ CSN, 1924, p.2.
} 
Nesse sentido, apresentaria as discussões estabelecidas pela equipe técnica em relação as duas novas fontes consideradas mais viáveis: as lagoas do Jiqui e do Pitimbu. Optaria pela primeira não só pela melhor qualidade e maior quantidade de água $\left(1.413 .505 \mathrm{~m}^{3}\right.$, ou mais de 50 vezes o volume necessário para comportar a previsão de crescimento demográfico) ou pela sua distância dos centros habitacionais e da linha férrea (considerados elementos poluidores), mas principalmente pela maior eficiência e economia que a construção da adutora que levaria a água da lagoa ao reservatório central na Cidade Alta permitiria: de baixa pressão, era possível utilizar materiais mais econômicos em vários trechos da adutora. ${ }^{50}$

\footnotetext{
"Quer dizer, Exmo. Sr. Governador, que agora temos em JEQUY cerca de 52 vezes o volume de que necessitamos, de águas limpidas, o que nos authoriza a afirmar, levando-se em conta a capacidade de armazenamento da lagoa, que ali temos mais do que o sufficiente para a cidade, no grao de desenvolvimento imaginado, ou mesmo se lhe dobrando a população calculada.
}

A linha adductora partindo da margem da lagoa, altitude de 6 metros, galga apos um kilometro apenas de desenvolvimento, o taboleiro na altura de 46,500 [metros], e se manterá depois nas proximidades desta altura até o kilometro 4. As pressões de trabalho são, consequentemente, pequenas e dahi a possibilidade de uma canalisação economica.

$[\cdots]$

Ora, como já assignalei a linha adductora da lagoa JEQUY é uma linha de baixa pressão, tendo varios trechos no grade plazometrico, nos quaes não há pressao interna dando-se o escoamento livremente. Pode-se portanto empregar um material mais leve com real economia. Assim, projectei, tambem, uma canalisação em cimento armado para entrar em competencia economica [...].

Para agir com absoluta segurança, [...], vou executar varios tubos de experiencia, que nos habilitará julgar das possibilidades de execução, dependentes da confecção e manejo das formas, da resistencia do tubo a pressão d'agua e ao transporte, e finalmente do seu custo real". ${ }^{51}$

Esse tipo de discussão eminentemente técnica permeia, pela própria natureza do trabalho, todo o relatório. Mas daí é possível depreender, ainda que parcialmente, a implicação que a emergência desse novo saber - o urbanismo - teria para a compreensão, ou, mais ainda, para a construção da própria forma de compreensão dos problemas da cidade e, em conseqüência, para propor a sua transformação.

A preocupação com a eficiência, a economia e a exeqüibilidade (incluindo o teste das soluções propostas), por exemplo, é uma característica que marca a atuação de vários urbanistas de viés sanitarista no Brasil e que ajuda a explicar a concretização de muitos dos projetos de Saturnino de Brito. ${ }^{52}$ A citação a Brito, mais uma vez, não é ocasional: influência no plano geral de Novaes para Vitória, em $1917,{ }^{53}$ é explicitamente citado como referência e parâmetro (a partir dos dados do Plano de Saneamento do Recife - 1909-15) para aferir a excelência de sua proposta para o sistema de esgotos do bairro da Ribeira: "para confirmação dos numeros por nós determinados nos projectos de esgotos é justo que nos apoiemos em alheia experiência mormente quando ella é de um mestre reconhecido da especialidade, qual o illustre Engenheiro Saturnino de Brito". ${ }^{44}$

Essa aproximação, ou filiação, à "tradição" do urbanismo sanitarista e, em particular, à "teoria urbanística" e à prática de Brito se torna mais evidente nas suas soluções para o

\footnotetext{
${ }^{50}$ Cf. CSN, 1924, p.03-09.

51 Ibid., p.02; grifos nossos.

${ }_{52}$ Cf. Andrade, 1996, p.304.

53 Mendonça, 1999.

${ }^{54}$ CSN, 1924, p.12.
} 
projeto urbano. A solução para as redes de saneamento não são entendidas desvinculadas da reforma da cidade existente e da previsão de seu futuro crescimento: "as obras de saneamento não se limitam somente ao abastecimento de agua e esgotos", afirmaria Novaes; ${ }^{55}$ incluiriam também o traçado de novas ruas, o aproveitamento dos terrenos alagados, a crítica e a reforma da cidade existente, pensada numa concepção de plano geral.

Mais ainda, faria dos elementos técnicos do sistema partes a compor, ordenar e transformar a paisagem natural e urbana. Nesse sentido, são muito significativas as propostas de transformação da Praça André de Albuquerque em um centro administrativo, destruindo a configuração do sítio primeiro de ocupação da cidade para a introdução dos edifícios do Palácio da Justiça, do Congresso do Estado e do Palácio da Higiene e Agricultura; de aproveitamento de um coreto na praça Leão XIII, na Ribeira, como uma estação elevatória; de construção de uma Avenida do Saneamento para receber o coletor geral dos esgotos; e de construção do reservatório central (que exigiria a demolição de um quarteirão inteiro) como o principal marco visual da cidade, com sua torre de quase vinte metros de altura.

Contudo, a intervenção no tecido urbano da cidade existente proposta pelo plano é, de maneira geral, sutil, pontual. No esquema gráfico da reforma da Cidade Alta, documento que compõe o já citado relatório da CSN, percebe-se que, à exceção do radical parcelamento da Praça André de Albuquerque e da implantação do reservatório central - não há nenhuma proposta, pelo menos nesse momento, de retificação das vias existentes, de realinhamento dos edifícios ou de regularização dos quarteirões.

No blueprint com as linhas gerais do projeto das canalizações de esgoto para os bairros da Ribeira e da Cidade Alta, incluindo a indicação do emissário submarino para despejo dos dejetos a 1,5 km da costa, percebe-se também a manutenção das linhas gerais do traçado urbano herdado do período colonial. Mesmo o novo traçado para o "Bairro operário" - localizado na chamada zona dos cômoros, a área de dunas ao norte da cidade, entre a Ribeira, o rio Potengi e o oceano - estruturava-se a partir do prolongamento das vias principais existentes.

Essa proposta da CSN, entretanto, não significou uma inversão na lógica sanitarista de pensar, ou submeter, a forma urbana a partir da melhor solução das redes de saneamento. A adaptação dos preceitos urbanísticos a cada realidade era mediada pelo rigor técnicocientífico, o que permitiria, por exemplo, como Novaes o faria para Natal, propor o aproveitamento dos terrenos alagados, no caso, a Lagoa do Jacob, nas Rocas, e os terrenos localizados nos fundos do teatro, na Ribeira; ademais, não se pode deixar de mencionar que a flexibilidade dos projetos, adequando-se às condições materiais existentes - o que não deixa de revelar o pragmatismo da formação politécnica no Brasil, ou no Rio de Janeiro, pelo menos -, faziam parte do conjunto de procedimentos dos urbanistas sanitaristas. ${ }^{56}$

Há ainda um último aspecto a marcar em relação ao conjunto documental que secunda o Plano Geral das Obras de Saneamento de Natal. Para além da representação técnica da cidade - traduzida na planta cadastral e topográfica, por exemplo, com a indicação do trajeto dos trens e dos bondes ${ }^{57}$-, outro espaço, outra paisagem urbana pode ser entrevista nas fotografias que ilustram as páginas do relatório. A preocupação em esquadrinhar, mapear e, por fim, construir o "diagnóstico" da cidade em crise acabou revelando uma paisagem que

\footnotetext{
55 Ibidem, fl. $\mathrm{s} / \mathrm{n}$.

56 Como Andrade (1996) discute a respeito de Saturnino de Brito.

57 O primeiro documento cartográfico de Natal desde o mapa do Atlas do Império do Brasil, de 1864 (citado no capítulo I) considerando que nunca foi encontrada a planta cadastral levantada e organizada por volta de 1908; a mensagem de governo desse ano anunciava a conclusão do "primeiro trecho da carta da cidade" (Maranhão, 1908, p.10).
} 
não era retratada nas suas representações oficiais, nas narrativas fotográficas de um Manoel Dantas ou que ilustram, em paralelo, o livro de Rocha Pombo. ${ }^{58}$

Mas, que cidade é essa que se revela nos documentos fotográficos da CSN? É, de fato, a cidade dos operários, daqueles que viviam às margens do porto e das atividades portuárias; mais ainda, dos que sobreviviam às margens do processo de modernização, das representações progressistas, que vivenciavam a "crise" da cidade moderna em formação, impedidos ou sem condições de acesso às, como se dizia, benesses e maravilhas do mundo civilizado; aonde o bonde não chegava. Mais ainda, não é um espaço resquício do período colonial, aqueles não normatizados, não é a não-cidade tematizada pelas narrativas constituintes da história da cidade; é, isto sim, um espaço decorrente do próprio processo de modernização. O bairro das Rocas se configurou como um dos "espaços da pobreza" de Natal quando, no final do século XIX, começaram a recrudescer as normativas higienistas, com a conseqüente proibição das tipologias construtivas acessíveis ao (baixo) poder aquisitivo das camadas populares, como a taipa. ${ }^{59}$

As dificuldades financeiras foram maiores do que as possibilidades de execução do plano organizado por Henrique de Novaes. Em novembro de 1925, funcionando contiguamente à Repartição de Serviços Urbanos e já sob direção de Paulo Coriolano, exassessor de Novaes e engenheiro responsável pelos dois órgãos, a CSN encontrava-se com todo o material comprado, pago quase totalmente e desembarcado para execução do projeto; mesmo assim, apenas o saneamento do Oitizeiro e a perfuração de alguns poços tubulares haviam sido realizados. ${ }^{60}$ Parte do sistema de abastecimento d'água, de esgotos e de canalização das águas pluviais na Ribeira (solucionando por alguns anos o problema de inundações no bairro) seriam concretizados nos anos seguintes.

Além do construído, as propostas de Novaes permaneceram no horizonte do debate político e, principalmente, técnico em Natal, informando diversas ações da administração de O'Grady, constituindo-se como base (a partir da planta topográfica) para o Plano Geral de Sistematização de Palumbo e para o Plano Geral de Obras do Escritório Saturnino de Brito (que, por exemplo, incorporaria a proposta original de uma Avenida do Saneamento, a atual Avenida do Contorno), na década de 1930.

Se o ano de 1924 foi muito significativo, como afirmamos no início deste capítulo, para o processo de modernização por que Natal passaria na década de 1920, não se pode deixar de mencionar, como um desses eventos simbolicamente importantes, o falecimento de Manoel Dantas. Um dos intelectuais mais articulados da cidade durante a Primeira República, entusiasta dos signos modernos e do processo de modernização e autor de uma das narrativas mais eloqüentes sobre a sua história - a conferência "Natal daqui a cinquenta annos" -, sucumbia ante uma das constantes epidemias que assolavam a cidade, em 15 de junho, pouco mais de um mês depois de assumir a presidência da Intendência Municipal; sucumbia ante as condições precárias da cidade que ajudaram a configurar a imagem do atraso tão combatida, e tão decantada, pela elite do qual Manoel Dantas fez parte. Esse acontecimento precipitou o retorno do engenheiro Omar O'Grady a Natal, que, indicado por Dantas, seu sogro, para compor o conselho da Intendência, acabou assumindo o cargo de presidente em novembro desse mesmo ano.

\footnotetext{
58 as fotos de Manoel Dantas foram publicadas em Miranda (1981), mas com tamanho muito reduzido e de baixa qualidade gráfica; o livro de Rocha Pombo (1922) é ilustrado por vários panoramas da paisagem urbana de Natal, como já mencionado no capítulo II.

${ }^{59}$ Santos, 1998.

${ }^{60}$ Cf. Medeiros, J.A.B. (Mensagem de Governo do RN), 1925, p.104-107.
} 
Assumindo as esperanças de retomada do processo de modernização da cidade, que haviam sido depositada em Manoel Dantas, e partindo da base técnica construída pelos estudos e propostas coordenadas por Novaes, O'Grady se tornaria um personagem-chave para entender o projeto moderno que seria rearticulado na segunda metade dos anos 1920, como será discutido a seguir. 


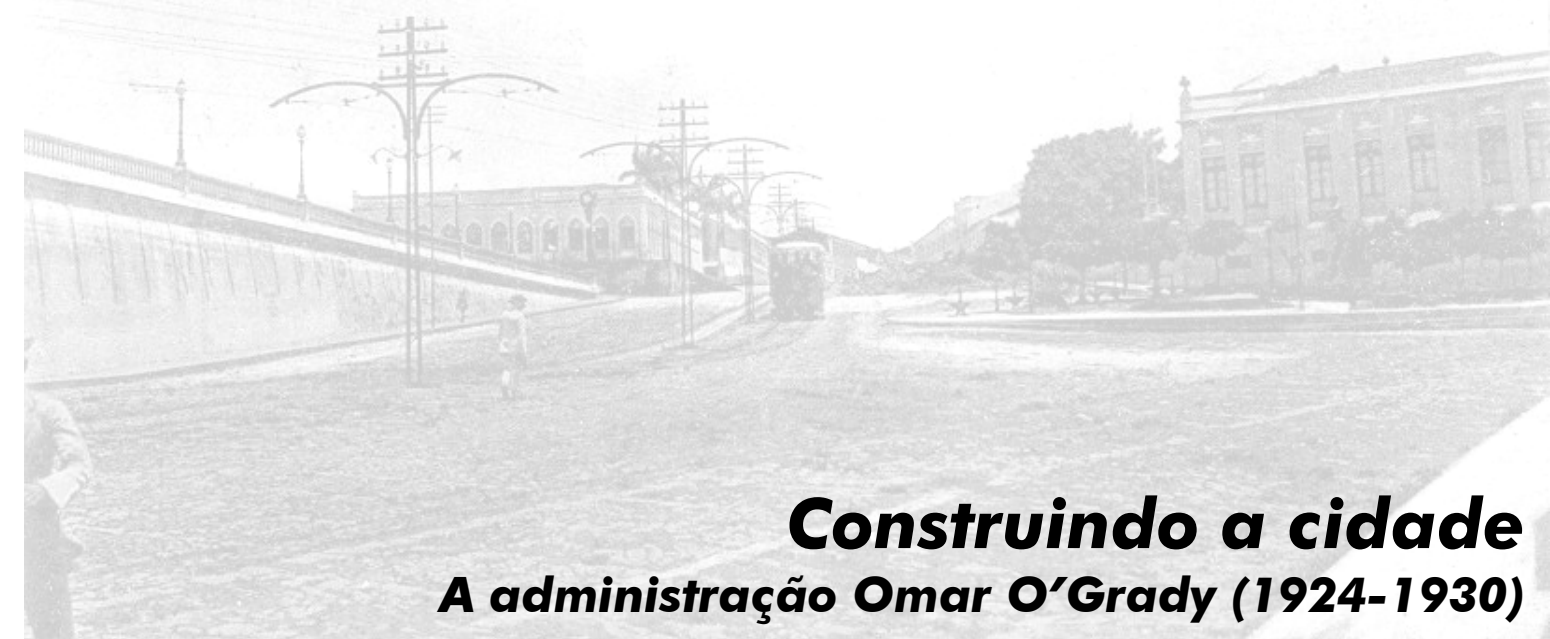


Quando o engenheiro Omar Grant O'Grady assumiu o seu segundo mandato a frente da presidência da Intendência Municipal de Natal, em janeiro de 1929, a percepção de que Natal era uma outra cidade - ou uma cidade de fato, se seguirmos as representações que fundamentaram a construção da sua história - tornava-se cada vez mais evidente para as elites locais, em especial para o meio intelectual.

Percepção que baseava na maior dinâmica da vida urbana, da obrigação social do footing, das danças modernas - como o charleston, o rag-time, o two-step - de ritmo sincopado, cuja vibração parecia corresponder à agitação e a velocidade atribuída à cidade moderna; na introdução do automóvel na vida cotidiana, o que implicaria inclusive na mudança do carnaval - evento que se deslocaria para as avenidas estruturadas a receber um corso de veículos -, substituindo paulatinamente o popular "entrudo patuscador"; na vida social noturna mais diversificada, dos bailes elegantes no Natal-Club ou, a partir de 1928, no Aero-Club; na constância da passagem e pouso dos aviões e hidro-aviões que cruzavam os ares da cidade devido às aventuras dos raids aéreos ou à incipiente rota comercial que se estruturava ao longo da costa atlântica das Américas; na diretriz "progressista" do governo estadual, que incentivava a difusão do feminismo e possibilitara o voto feminino nas eleições de 1928. Entretanto, essa percepção vinculava-se principalmente às transformações urbanas empreendidas pela administração municipal de O'Grady desde o final de 1924, quando assumiu a vaga deixada em aberto depois do falecimento de Manoel Dantas.

Dentre os muitos artigos que ajudaram a construir essa significância, podemos destacar, como forma de estabelecer alguns pontos para entender o papel central que O'Grady ocuparia na rearticulação do processo de modernização urbana - na construção de um projeto de cidade moderna - dos anos 1920, um em especial do então jovem intelectual e estudante de Direito Octacílio Alecrim.

As circunstâncias da elaboração do artigo explicam essa escolha. Em fins de 1929, lembraria Alecrim em seu livro de reminiscências publicado nos anos 1950, percorreria a cidade e automóvel, a convite do governador do estado, Juvenal Lamartine, para escrever um texto - que seria depois publicado no jornal A República - sobre as "Realizações da Prefeitura de Natal”. Inicialmente acompanhado pelo governador e pelo próprio prefeito O’Grady, que apareceu "trazendo notas, exemplares da sua Mensagem e documentado dossiê referente a sua gestão na Prefeitura", 2 e depois deixado por conta própria para indagar e tomar suas próprias notas, Alecrim construiria um artigo extenso - para o tamanho médio dos jornais de então que pode ser tomado como uma mensagem para-oficial da administração municipal. Contudo,

\footnotetext{
1 As mudanças no cotidiano da população ocorridas nos anos 1920 são discutidas por Jamilson Soares (1999, em especial o cap. 3).

2 Alecrim, 1957, p.215.
} 
uma mensagem que se insere no debate técnico e cultural de formação do saber urbanístico no Brasil, se considerarmos as referências mobilizadas pelo autor desde os seus artigos anteriores, em que discutiu o plano Agache, as contribuições teóricas de Unwyn e Camillo Sitte, as palestras de Anhaia Mello - por cujas idéias nutria grande entusiasmo - no Rotary Club e no Instituto de Engenharia de São Paulo, por exemplo. ${ }^{3}$ Afirmaria Alecrim, num diapasão semelhante a outros artigos coetâneos:

\begin{abstract}
"Quem tenha percorrido com serenidade os serviços prestados pelo engenheiro Omar O'Grady à cidade de Natal, durante os cinco anos e meio do seu governo, não deixará de admirar nele um prefeito realizador. Ele teve a virtude rara de ascender à presidência da edilidade com uma noção muito alta dos negócios públicos. Educados nas Universidade americanas, onde seu espírito firmou uma visão esclarecida dos valores reais, todas as suas iniciativas esplendem num sentido amplo de progresso e civilização". ${ }^{4}$
\end{abstract}

O engenheiro Omar Grant O'Grady nasceu em Natal a 18 de Fevereiro de 1894. Filho do canadense, de origem irlandesa, Alexandre James O'Grady e da norte-rio-grandense Estefânia Alzira Moreira O'Grady, viveu e estudou na cidade até o início da década de 1910, quando, possivelmente entre 1913 ou 1914, embarcou para Chicago, nos Estados Unidos, onde cursaria Engenharia Civil pelo então Armour Institute of Technology - AIT (atualmente Illinois Institute of Technology - IIT). Formando-se em 1917, com um projeto de uma represa e uma hidrelétrica ("Design of a Hollow Dam and Hydro-Electric Plant") para French's Mill, em New York, retornou ao Brasil para trabalhar na IFOCS, seção RN, entre 1918 e 1923, quando foi contratado pela inglesa Norton Griftth and Company para superintender a construção da barragem do Acarape, no Ceará. ${ }^{5}$

Com o falecimento do seu sogro, Manoel Dantas, em 15 de junho de 1924 - que ocupava então o cargo de presidente da intendência municipal desde 01 de maio desse mesmo ano por indicação do Partido Republicano Federal -, Omar O'Grady, engenheiro educado nos Estados Unidos, de onde trazia o seu cabedal de conhecimentos e a influência da iniciativa realizadora e pragmática, como os jornais compraziam-se em informar, passou a ser o nome mais lembrado para assumir o cargo vago. ${ }^{6}$ Se a formação norte-americana dava mais credibilidade à indicação de O'Grady como presidente da intendência e constitui-se numa influência fundamental para discutir a sua administração e o novo "projeto" modernizador das elites que se articulou na segunda metade dos anos 1920, pode-se afirmar que os vínculos estabelecidos com o grupo dominante de então lhe deram a legitimidade necessária para que assumisse o cargo. Casado com Isabel Dantas, primogênita de Manoel Dantas, adentrava assim na trama de relações familiares do grupo político e econômico dominante; ${ }^{7}$ ademais, seu pai, Alexander O'Grady, estava, desde o final do século XIX, estabelecido como construtor em Natal, onde exercera o cargo de intendente no triênio 1896-1898. ${ }^{8}$

O’Grady herdaria de Manoel Dantas não somente o cargo na Intendência de Natal, mas as expectativas e responsabilidades pela transformação da cidade que lhe foram imputadas por parte da elite política e intelectual. Obviamente, não o sonho da metrópole feérica

\footnotetext{
${ }^{3}$ Cf. Alecrim, 1929a; 1929b; 1929c.

${ }^{4}$ Idem, 1957, p.216.

5 informações baseadas nas entrevistas com os srs. Paulo O’Grady (em 2001), Osório Dantas e Edgard Dantas (em 2000), no The Cycle Class (1918) do AIT, enviadas por Catherine Bruck (em 2000), e em extratos d'A República.

${ }^{6}$ Cf. "um engenheiro de valor - Dr. Omar O’Grady e a sua capacidade de trabalho", A República, Natal, n.198, p.01, 31 ago. 1924.

7 Manoel Dantas, assim como Juvenal Lamartine, casou-se com uma das filhas do Cel. Silvino Bezerra, considerado o patriarca da chamada "oligarquia do Seridó"; eram, portanto, concunhados e tios de José Augusto (Cf. Araújo, M., 1998; Souza, 1989).

${ }^{8}$ Cf. Ferreira Chaves, 1896.
} 
idealizada em 1909, mas o próprio processo de construção de "uma cidade ainda por fazer", de "aspecto quasi primitivo", como diria um cronista pouco depois da posse de Dantas:

\begin{abstract}
“[...] Natal é uma cidade por fazere e o que nella se tem feito é sem plano, ás tontas, sem orientação e sem gosto. Por umas tantas conveniencias, que é preciso banir por completo, a cidade ainda apresenta este aspecto quasi primitivo. Nem tanto ao amor, nem tanto á terra. Com a mão firme no leme do barco que ora dirige, o Dr. Manoel Dantas há de leval-o ao porto do Progresso, isto é, ha de dotar a nossa capital, cuja topographia é tão encantadora, de grandes melhoramentos, [...]". ${ }^{9}$
\end{abstract}

Quando O'Grady a assumiu, em novembro de $1924,{ }^{10}$ a estrutura da Intendência Municipal era até então muito dependente do poder público estadual. Sem autonomia administrativa - apesar da regulamentação do Decreto que lhe originara, em 1890, ${ }^{11}$ seguindo a proposta de emancipação política dos municípios no processo de constitucionalização da República - ou econômica, o governo municipal em Natal nem mesmo tornara-se espaço para a constituição de um corpo técnico especializado que construiria sua legitimidade no discurso e na prática sobre a cidade. ${ }^{12}$ Permanecera nas mãos da velha figura dos coronéis, executores das diretrizes de reforma das administrações estaduais, como o Cel. Joaquim Moura (membro da intendência entre 1896 e 1914) e o Cel. José Lagreca, que antecedera Dantas.

Não se deve esquecer, para discutir esse vínculo estrito entre as esferas estadual e municipal de administração, que os Conselhos de Intendência eram instrumentos importantes para a manutenção do poder dos grupos políticos locais; afinal, era responsabilidade das intendências controlar as urnas e o processo de apuração no período de eleições.

Embora não tenha se referido de forma explícita, o artigo de Alecrim traz indícios de que, para além da realização de obras emblemáticas, como a (re)construção da Avenida Junqueira Aires e a construção da Avenida Atlântica (atual Getúlio Vargas ou Ladeira do Sol), ou dos programas mais amplos de reforma urbana, como o calçamento das vias urbanas da cidade e a construção das galerias para drenagem das águas pluviais da Ribeira, o grande marco da administração O'Grady tenha sido a reestruturação administrativa que redefiniu - ou revelou - o papel da Intendência Municipal na direção do processo de modernização da cidade. Como afirmaria o jovem autor:

\footnotetext{
“Outro aspecto da orientação fecunda do Prefeito Omar O’Grady assenta na nas suas visitas equilibradas para com as finanças do município. Ele encara porém o problema econômico com o mesmo senso prático do homem da Norte América: a função da riqueza é multiplicar a riqueza com a sua boa aplicação. A fim de animar o progresso da cidade que dirige, a Intendência Municipal firmou (Resolução n.290) uma taxa específica por conta do proprietário marginal em custeio dos melhoramento públicos". ${ }^{13}$
}

\footnotetext{
9 "Impressões de Domingo", A República, Natal, n.100, p.01, 06 maio 1924.

${ }^{10}$ Cf. "Intendencia Municpal - Eleição e posse do novo presidente", A República, Natal, n.251, p.01, 02 nov. 1924.

11 "Decreto n.8, de 16 de Janeiro de 1890", Gazeta do Natal, Natal, n.152, p.03, 25 jan. 1890; dissolvia a Câmara Municipal e atribuía as suas competências, dentre elas: "Fixar a receita e despeza publica do município"; "Ordenar a despeza e arrecadar as rendas"; "Ordenar e fazer executar todas as obras muncipaes e prover sobre tudo quando diz respeito á policia administrativa e economia do municipio e seu termo, assim como sobre a tranquilidade, segurança, commodidade e saúde de todos os seus habitantes"; contudo, o governador do estado reservava-se o "direito de restringir, suprimir quaesquer das attribuições que [...] são confiados ao conselho de intendencia municipal, quando assim convenha ao bem publico do municipio; bem como o de substituir, em todo ou em parte, o dito conselho, e de nomear substitutos [...]."

12 Ao contrário, por exemplo, de São Paulo, onde se formou a Diretoria de Obras Públicas, sucedânea da estrutura da Intendência em 1899, esfera de formação de profissionais e de onde sairiam nomes pioneiros da prática urbanística no Brasil, como Victor da Silva Freire (Cf. Simões Jr., 1991; Leme, 1991).

13 Alecrim, 1957, p.217.
} 
A proposição da taxa de benefício a qual se refere o artigo seria regulamentada apenas em 1930 - como um dos principais meios para angariar os recursos necessários à implementação do Plano Geral de Sistematização. Uma proposta que foi pensada como um arremate para o processo de reestruturação das leis e finanças municipais que foram levadas a cabo a partir de 1925 - passo fundamental, defendia-se, para a viabilização do amplo programa de reformas e expansão urbanas que consideravam decisivo para a superação do "aspecto quasi primitivo" da cidade.

\title{
Por uma nova Intendência Municipal (1924-1928)
}

Um editorial do jornal A República, de maio de 1925, já colocava com clareza o novo papel que, mais do que ser atribuído, a Intendência deveria assumir.

\begin{abstract}
“O engenheiro Omar O’Grady vem imprimindo novo cunho à Intendência Municipal de Natal. Faziam parte de seu programma dois objetivos principais e de carater inadiavael. Era o primeiro a organização dos varios departamentos, [...]. Por este systema, os diversos departamentos ficam sob a direção de tres secções autonomas entre si: a do Protocolo, a do Expediente e a de Obras. [...] Segundo ponto de vista administrativo haveria de ser a methodização ou codificação das nossas leis municipaes, pois as existentes, com serem esparsas, já não satisfaziam as novas necessidades expansionistas, por assim dizer, de Natal". ${ }^{14}$
\end{abstract}

O início da administração de O'Grady foi marcado portanto pelos esforços de reestruturação das atividades da Intendência. Impôs-se desde o início a busca da autonomia política e, em menor medida, econômica do município, dentro, é claro, dos limites da estrutura e da hierarquia de poder local da qual fazia parte. Além de assumir os preceitos estabelecidos pelo decreto de 1890, O'Grady, em seu primeiro ano de governo, aprovaria e publicaria o regulamento para uma "reforma" administrativa do município, estabelecendo uma nova seção de obras e dando novas atribuições à Intendência; conseguiria ainda do governo estadual a transferência dos impostos de décima urbana e da taxa de lixo (Decreto n. ${ }^{\circ}$ 262, de 25 de Fevereiro de 1925) e a autorização para contrair empréstimos até o valor de 50:000\$ (50 contos de réis) (Decreto n. ${ }^{\circ} 279$, de 9 de Setembro de 1925). ${ }^{15}$

$\mathrm{O}$ incremento das rendas municipais, atribuído a instituição desses impostos, teria desdobramentos nos anos seguintes. Primeiro, com a sistematização do processo de aquisição e da forma de pagamento do "habite-se"; ${ }^{16}$ e, depois, com a instituição do "código de obras" municipal, por meio da lei n.4, 2 de setembro de 1929, que finalmente reuniu as normas e prescrições urbanísticas e construtivas em um mesmo instrumento, com o intuito de facilitar a ação da administração municipal no controle do processo de urbanização de Natal.

Apesar das reclamações contra o que se considerava uma restrição aos direitos de propriedade, a imposição de padrões mínimos de construção - e de "esthetica" urbana - era considerada uma necessidade para o crescimento correto e salubre da cidade. ${ }^{17}$ Ademais, a legislação poderia garantir - com uma estrutura mínima de fiscalização que se buscava assegurar por meio da reforma administrativa da Intendência -, pelo menos nas áreas mais centrais, a manutenção ou a configuração de uma paisagem urbana mais densa e mais dinâmica. Assim, por deliberação logo na segunda reunião do Conselho Municipal, foram proibidas a "construção e reconstrução de predios de menos de dois pavimentos nas ruas Dr.

\footnotetext{
${ }^{14} \mathrm{~S} / \mathrm{t}$, A República, Natal, n.120, p.1, 29 maio 1925.

15 Medeiros, 1925, p.121-22.

16 "Governo do Município: Resolução n.277”, A República, n.143, p.3, 03 jul. 1927.

${ }^{17} \mathrm{~S} / \mathrm{t}$, A República, n.11, p.1, 15 jan. 1925.
} 
Barata e do Commercio; Praças Augusto Severo e Leão XIII, e avenidas Tavares de Lyra e Sachet" ${ }^{\prime 18}$ - os principais espaços e vias do bairro comercial da Ribeira.

A elevação e mesmo a criação de novos tributos urbanos repercutiram, é certo, na população como um todo. Em 1926, por exemplo, o jornalista Sandoval Wanderley começou uma pesada campanha denunciando os altos impostos que "sufocavam o comércio" por intermédio do seu jornal, fundado em 1923, Folha do Povo. Contra as constantes acusações, O'Grady decidiu processar judicialmente o proprietário da folha. Contudo, “depois de marchas e contramarchas, o Tribunal da Justiça resolveu anular o processo por estar completamente falho". Impossibilitado de calar legalmente o periódico, seguiram-se as mais diversas formas de perseguição: multas, tentativa de arresto dos bens, agressões físicas e ameaça de morte, o que determinou o fechamento do jornal em outubro de $1927 .{ }^{19}$

Embora não seja possível acompanhar as críticas que se estabeleceram, pode-se perceber, mesmo nas páginas do jornal oficial, alguns indícios do custo social do processo de modernização então em marcha. As restrições às tipologias construtivas mais populares foram eliminando paulatinamente, desde o final do século XIX, as habitações mais pobres das áreas centrais. Com o crescimento demográfico da cidade nos anos 1920, o chamado "problema do tecto" se tornaria mais premente, como reconheciam os escritos oficiais (ou oficiosos).

\footnotetext{
"A falta de casas, em nossa terra, é uma consequência do descaso que se vem notando em todo o Brasil, [...], sem, até agora, resolvel-o de forma satisfatoria para as populações mais desfavorecidas.

$[\cdots]$

A nossa capital está ainda cheia de 'mocambos'. [...]. Portador de males sem conta, para a população e para a cidade, o 'mocambo'desperta um infalivel ar de nôjo e de penuria, como se fora exclusivo factor do pauperismo, da mendicancia, da miseria". ${ }^{20}$
}

Frente aos problemas ocasionados pelos mocambos - representados como elementos de atraso e de insalubridade, num claro eco às discussões que se estabeleciam em Recife $^{21}$-, a única saída, apontava-se, estava no incentivo às construções de casas e vilas operárias. Contudo, as propostas que esboçaram alguma medida para o enfrentamento do que hoje se chama déficit habitacional - como, por exemplo, a proposta de um bairro operário no plano elaborado por Novaes, ou a consolidação do Alecrim como bairro operário, no plano elaborado por Palumbo - permaneceram distantes do horizonte de ações dos governos municipal e estadual.

O crescimento horizontal da cidade e o conseqüente aumento das distâncias a percorrer entre os locais de moradia e de trabalho (em sua maioria localizados nas áreas centrais, como o porto, o comércio, os serviços públicos, as fábricas) exacerbaram as dificuldades de sobrevivência da população mais carente. Os trabalhos, a cargo da RSU, de prolongamento da linha de bondes do Alecrim até - o que seria depois - o bairro de Lagoa Seca, no início de $1926,{ }^{22}$ suscitou uma série de reflexões sobre o problema do transporte em Natal e apontou, ainda que de forma tímida, para algumas possíveis soluções.

\footnotetext{
18 "Varias", $A$ República, n.11, p.1, 15 jan. 1925.

19 O episódio é relatado por Souza (1989, p.184-185), baseado no livro de memórias de Wanderley (Minha Luta Política, Natal, s.e., 1954); não tivemos acesso a esse periódico e nem ao livro durante a pesquisa.

20 "O problema do tecto", Diário de Natal, n.63, p.1, 17 mar. 1926.

${ }^{21}$ Cf. Lira, 1996, p. 07-12.

22 "Linha de bondes: Tyrol-Lagoa Secca", A República, n.33, p.1, 10 fev. 1926.
} 


\begin{abstract}
"Em Natal, onde as comunicações são difficeis e os perimetros se estendem por vastas extensões, o bonde é o único processo, relativamente barato, capaz de nos fazer poupar as fadigas das peruas. Mas, a passagem num tranvia eletrico, em Natal, onde sua população não pode ostentar luxo, nem arrostar fortunas, custa $\$ 200$ [duzentos réis], no curto espaço de uma seção, o que o torna inacessivel a bolsa do pobre. Quanto ao preço do automovel, é melhor silenciar. [...]. Ora, a solução que se desenha como conveniente ao interesse publico seria instituir carros de segunda classe, ao preço de $\$ 100$ a passagem, destinados à gente pobre, que também precisa locomover-se, com facilidade, ao longo de nossas principais artérias". ${ }^{23}$
\end{abstract}

Sobre o tema, voltar-se-ia a carga pouco tempo depois, cobrando tanto os carros de segundo classe quanto um calçamento adequado ao tráfego de veículos na capital.

\begin{abstract}
"Dentro de poucos meses estarão trafegando, até o pittoresco povoado de Lagôa Secca, os carros da R.S.U. de Natal. [...] Com esse melhoramento, aliás relevante e de vantagens sem conta para a população que alli vive, luctando com extraordinárias difficuldades de transporte, assignada a actual superintendencia, de modo promissor, a sua tarefa, dotando natal de uma grande passeio como precisavamos ter. [...] a nossa capital ressentia-se mesmo de um percurso maior de viação urbana, pois aos autos nào offerecem as ruas da cidade o acesso necessario, a menos que estivessemos dispostos a supportar as consequencias dos barrancos, dos calçamentos ou das travessias arenosas e incommodas. Agora, porém, com o novo ramal prestes a ser inaugurado, com a esperança de avançar ainda mais, até conseguir o bairro do Tyrol, vê-se como será coroada dos melhores exitos iniciativa da actual administração.
\end{abstract}

\title{
$[\ldots]$
}

Um ponto, entretanto, cabe despertar a reflexão do engenheiro Paulo Coriolano: é o preço das passagens para a linha de Lagôa Secca. [...] Constituída, toda ella, de gente pobre, de gente operaria, que não possuem, diariamente, vestimenta nem calçado capaz de se lembrar com os passageiros de gravata, essa gente, que vai ser, na verdade, a mais beneficiada pelo bonde do novo traçado, não pode, absolutamente, dispor de 600 reis dalli a Ribeira, ou sejam $1 \$ 200$ [mil e duzentos réis] diarios, num total de $3 \$ 200$ mensaes.

E com a mesma confiança que traçamos, domingo, um 'suelto' sobre o mesmo assumpto, esperamos a inauguração dos carros-reboque de segunda classe e onde as passagens sejam cobradas, tendo em vista a situação financeira daquella população". ${ }^{24}$

À população mais pobre, sem ocupação certa, ou para aqueles que erravam nas áreas centrais, restava a repressão - por parte dos guardas municipais ou da força policial do estado - e o recolhimento ao Dispensário Sinfrônio Barreto, cuja inauguração, em meados de 1925, suscitou a proibição legal da atividade da mendicância. ${ }^{25} \mathrm{O}$ controle, ou o saneamento, da mendicância, decisão na qual O'Grady teve participação direta, passou assim a fazer parte dos discursos sobre as reformas urbanas da cidade. ${ }^{26} \mathrm{Em} 1929$, o Dispensário atendia a aproximadamente trezentas famílias "desvalidas" que, sem a assistência pública, na forma de alimentos e vestimentas, poderiam ser "fatores de perturbação social". Destarte, mantendo estrito controle sobre aqueles que dependiam da "equitativa distribuição de esmola" para sobreviver, era possível "reprimir a mendicidade de indústria" e "sanear a urbe da legião de pedintes e falsos mendigos" - o que era considerado outra das grandes realizações da

\footnotetext{
23 "Problema de transporte", Diário de Natal, n.67, p.1, 21 mar. 1926.

24 "O novo ramal", Diário de Natal, n.73, p.1, 28 mar. 1926.

25 "Obra philanthropica”, A República, n.148, p.1, 07 jul. 1925.

${ }^{26}$ Soares, 1999 , p.70-71.
} 
administração O’Grady, um dado positivo de civilização que equiparava as ações da Intendência às obras reformistas levadas a cabo na Europa. ${ }^{27}$

A reorganização administrativa da Intendência, a consequente "methodização" da legislação urbana e a redefinição do seu papel político na direção do processo de modernização da cidade implicaram também na expansão do controle do poder municipal sobre as esferas públicas e privada da vida urbana. Percebe-se um esforço contínuo pela uniformização na forma de usar o espaço urbano; pela criação de um patamar mínimo de sociabilidade urbana que fosse condizente com a imagem projetada de progresso e civilização para a cidade.

Nesse sentido, deve-se chamar a atenção para o início do funcionamento do relógio elétrico com o "horario official" da cidade, localizado na balaustrada da Avenida Junqueira Aires e ligado diretamente ao prédio da Intendência. Esperava-se que a uniformidade do horário pudesse beneficiar os habitantes dos dois bairros centrais no cumprimento dos seus compromissos sociais e, principalmente, de trabalho. ${ }^{28}$ A padronização das placas e da numeração de ruas, praças e casas pode ser lida nesse mesmo esforço - possibilitava o cadastramento eficiente dos edifícios e lotes urbanos para a cobrança dos tributos municipais que passavam a entrar em vigor. ${ }^{29}$

O aumento do tráfego urbano, de bondes e automóveis, exigiu da Intendência a proposição de algumas normas básicas que estabelecessem signos comuns de sinalização indicando mudança de trajetos, paradas, retornos, curvas - para os "chauffers", além da delimitação de pontos de estacionamento e dos limites de velocidade na zona urbana - 20 $\mathrm{km} / \mathrm{h}$ e, nos locais mais movimentados, $10 \mathrm{~km} / \mathrm{h}$; discutia-se, ainda, formas para evitar a lotação dos bondes em "certas horas do dia". 30

Apesar da importância dessa série de medidas, como se reconhecia, o programa de calçamento da cidade constituiu-se o principal esforço para superar o que se considerava a imagem de atraso do espaço herdado do período colonial, com suas "ruas bolorentas e coloniais" - como definiria um cronista em 1926. ${ }^{31}$ A cobertura de muitas ruas da cidade com um empedrado regular, o macadame pixado ou os paralelepípedos sobre base de concreto, materiais permanentes que não se desfaziam à primeira enxurrada, não só permitia um trânsito mais fluido aos autos, ônibus e caminhões, cada vez mais comuns na década de 1920, mas transformava, construía e uniformizava o espaço público; estabelecia as distinções entre o público e o privado, com a valorização e delimitação de ruas, calhas, passeios, muros, configurava-se como um signo palpável de progresso e modernidade que poderia, por meio do chamado "coefficiente de calçamento", ser comparado a outras cidades. Como diria O’Grady, em 1929, em um artigo que avaliava a sua própria administração até então:

\footnotetext{
"Alem de estabelecer as condições de trafego e de superficies de rolamento compativeis com o desenvolvimento cada vez maior da autoviação, intensificado hoje com o transporte collectivo por meio dos autos-omnibus, devemos considerar que um bom calçamento transforma por completo o aspecto de uma rua, dando-lhe uma feição alegre com a construcção de novos passeios, corrigindo com o assentamento dos meios-fios os pequenos erros de alinhamento, acertando definitivamente o seu grade, resolvendo a drenagem das aguas pluviaes que resulta tambem na solução de pequenos problemas de saneamento, e realizando afinal, varios outros pequenos serviços complementares de aformozeamento, inclusive a arborização e illuminação, cujo conjuncto completa a transformação da rua, serviços estes que são sempre
}

\footnotetext{
27 Alecrim, 1957, p.220.

28 "Energia elétrica", $A$ República, n.156, p.1, 16 jul 1925.

29 "Várias", A República, n.11, p.1, 15 jan. 1925.

30 "Echos e fatos", Diário de Natal, n.259, p.2, 15 nov. 1925; "Em beneficio do trafego e do publico", Diário de Natal, n.125, p.1, 03 jun. 1926.

31 Torres, Luis. "A Cidade”, A República, n.71, p.1, 28 mar. 1926.
} 
levados a effeito com a construcção definitiva de um bom calçamento. Para exemplo basta citarmos, sem commentario, os casas das Avenidas Junqueira Ayres, Atlantica e Sachet (apenas começada), praça Augusto Severo e ruas Dr. Barata e José Bonifácio. Não precisamos insistir na valorização da propriedade beneficiada com o calçamento na rua em que está localizada. A valorização é uma consequencia tão immediata e tão certa que não ha espirito por mais rotineiro e pessimista que seja que, de bôa fé, ouze contestal-a". ${ }^{32}$

A análise comparativa dos coeficientes de calçamento - obtido através da divisão entre a quantidade de metros quadrados do serviço pela quantidade de habitantes - poderia ser considerado como um parâmetro para avaliar o grau de desenvolvimento de uma cidade. Contudo, para que este coeficiente exprimisse uma situação verdadeira fazia-se necessário “... tomar em conta a natureza, ou typo, do calçamento, pois muito mais vale um coefficiente 5 para calçamento de typo superior do que um coefficiente 10 resultante, no todo ou na sua quase totalidade, de pavimentação de alvenaria irregular ou empedramento ..." (O'Grady, 1929: $01)$.

Para iniciar sua análise, O'Grady apresentava dados referenciais das cidades alemãs (coef. 6), americanas (coef. 9), de São Paulo (coef. 6) e de Belo Horizonte (coef. 5.2); consideravam satisfatório o índice 10 para cidades de baixa densidade - como Natal. Justificava a escolha destes parâmetros comparativos para Natal,

\footnotetext{
“... porque deve servir padrão aquillo que já attingiu um certo grau de perfeição, e nunca o que está em plano baixo, semelhante apenas a cousa comparada. Não nos devem interessar os índices de calçamento de paízes atrazados, ou os das nossas próprias cidades mais rotineiras. Como, também, não devemos nos conformar com os erros ou falhas de outros. Não devemos ficar satisfeitos porque ha outras cidades no nosso país com coeficientes menores do que o nosso ...". ${ }^{3}$
}

Ao apresentar os dados de Natal (100.466 metros quadrados de calçamento, atingindo um baixo índice de 2,87; embora, ressalvasse que o pavimento de tipo superior, paralelepípedos e macadame pixado chegasse a apenas 26.955 metros quadrados, obtendo um índice pior de 0,77) O'Grady, exigente, reconhecia o baixo estágio de desenvolvimento de Natal segundo este parâmetro, o que acabava contradizendo os discursos entusiastas que transpareciam e que tentavam construir a imagem de uma Natal "moderna". A tarefa de incrementar este coeficiente começaria a ser tentada com a implantação do Plano Geral de Sistematização e as resoluções da Taxa de Benefício.

A discussão em torno das obras de calçamento e das suas formas de financiamento mobilizaram tanto as críticas oposicionistas que denunciavam a elevação sufocante das taxas de impostos quanto o debate técnico e intelectual sobre a proposta de uma Taxa de Benefício, elaborada em 1929 e aprovada no ano seguinte como o principal meio para arrecadar fundos para a realização do Plano Geral de Sistematização.

A proposição da taxa de benefício ia ao encontro da necessidade da busca de formas alternativas para financiar a modernização da cidade e, principalmente, viabilizar o Plano Geral de Sistematização de Giacomo Palumbo, entregue em definitivo em abril de 1930. A implantação do "imposto de calçamento", como esta taxa ficou popularmente conhecida, implicaria, em tese, numa maior autonomia do governo municipal em relação a estrutura de poder estadual. Tributaria e dividiria a responsabilidade com os proprietários do solo urbano as "... despesas de calçamento das ruas e passeios que elles se acham installados, porque se é

\footnotetext{
32 O’Grady, 1929

33 Ibid.
} 
certo que estes melhoramentos determinam o bem-estar geral de toda a cidade, [...], é indiscutível que por efeito desta acessibilidade os terrenos se valorizam rapidamente". ${ }^{34}$

Depois do debate - quase unilateral, pois as vozes discordantes não encontravam espaço no jornal oficial da cidade -, sobre a Taxa de Benefício, eram publicadas as resoluções n. 318 e 319, em 17 de junho de 1930, regulando a contribuição dos proprietários para a pavimentação das vias da capital potiguar nas zonas central e urbana. Eles ficavam a cargo de $2 / 3$ dos custos das obras, que incluíam o calçamento, meio-fio e passeios. Os pagamentos seriam ser feitos em prestações semestrais por um período máximo de dez anos; estavam isentos da contribuição compulsória aqueles que comprovadamente não podiam efetuá-la.

A constituição de um debate em torno desta taxa, assim como a proposta de zoning no plano e de uma comissão do plano da cidade, reflete o ambiente de formação de O'Grady e a crescente influência do urbanismo americano no Brasil. Influência que, a princípio, não se restringiu apenas ao debate entre intelectuais sobre instrumentos de gestão do City Planning, o zoning e a taxa de benefício, ou sobre a vida americana de metrópoles, arranha-céus e automóveis, a ressonância das palestras de Anhaia Mello ou dos trabalhos de Nelson Lewis como engenheiro da prefeitura de New York. ${ }^{35}$ Esta influência teria marcado diversas facetas da administração O'Grady, tentando avançar num processo de desvínculo entre a esfera técnica e a política. ${ }^{36}$

Ainda sobre as obras do calçamento, vale lembrar que foram em torno delas que mobilizaram-se as acusações e processos judiciais e administrativos no período pós-outubro de 1930. O’Grady seria acusado de improbidade, malversação dos recursos da intendência, com o suposto superfaturamento da reforma do cais Tavares de Lyra e do contrato para aquisição de paralelepípedos, entre outras. ${ }^{37}$ No início de 1932, o ex-prefeito seria absolvido, como registrou o Jornal A República. ${ }^{38}$

\section{A construção da cidade (moderna)}

O contrato celebrado em 22 abril de 1929, de acordo com a resolução municipal de 6 de abril do mesmo ano, entre a municipalidade - com o apoio do governo estadual - e o arquiteto Giacomo Palumbo, apontava para a necessidade de consubstanciar todas as obras e propostas empreendidas até então em um plano que, a partir daí, permitisse a coordenação e o controle efetivo do processo de crescimento da cidade.

Seria “... um plano geral e definitivo da cidade de Natal, de accôrdo com os ultimos preceitos de urbanismo para uma população até cem mil habitantes [Natal tinha aproximadamente 35 mil em 1930] e em condições de ser o mesmo desenvolvido ou irradiado de modo a poder acompanhar o futuro progresso da cidade". ${ }^{39}$ Delimitava, também, a abrangência do projeto, utilizando o zoneamento como imperativo ao controle do espaço urbano; a planta teria:

“... projecções de sombra, compreendendo os quarteirões administrativos, commercial, industrial, a cidade recreio e os bairros residencial e operario. [...] serão indicadas a localização da iluminação publica, viação urbana, arborização, passeios,

\footnotetext{
34 "Em prol da cidade III - a taxa de benefício - o preço do calçamento", A República, Natal, 14 jun. 1930, n.135, p.01.

${ }^{35}$ Cf. Dantas, C., 1923; Dantas, G., 1929a, b e c; Alecrim, 1929a e b, 1957.

36 Como observa Feldman (2000), nos anos anteriores à década de 1930 os conceitos, teorias e práticas do urbanismo americano eram discutidos e utilizados de forma ainda parcial e difusa no ambiente cultural e técnico brasileiro.

${ }_{37}$ Cf. A República, Natal, 22 mar. 1931, 06 maio 1931, 17 maio 1931.

${ }^{38}$ Idem, n.356, p.01, 09 jan. 1932.

39 "Relatório apresentado à Intendência Municipal de Natal, em 30 de janeiro de 1930, pelo prefeito Omar O’Grady". Natal: Imprensa Official, 1930.
} 
monumentos, abrigos, jardins, e praças publicas, locaes para feiras, mercados, matadouros, cemiterios e demais estabelecimentos municipaes". ${ }^{40}$

Discutir alguns elementos sobre o início da implantação do zoneamento no Brasil pode ajudar-nos a compreender a reestruturação do processo de modernização urbana ao longo dos anos 1920 em Natal; processo que seria consubstanciado no Plano Geral de Sistematização e que, pretendia-se, teria como principal instrumento o zoning.

Em 1929, Garibaldi Dantas, filho de Manoel Dantas, correspondente d'A República em São Paulo, publicou um artigo, por ocasião dos debates sobre o então recente contrato entre o governo municipal de Natal e o arquiteto italiano Giacomo Palumbo, que ilustra a escolha destas três cidades para discutir algumas das primeiras propostas de zoneamento para a cidade brasileira:

\begin{abstract}
“O urbanismo é a grande preoccupação moderna. Preoccupação perfeitamente justa uma vez que as cidades se tornaram núcleo central da vida moderna. [...]. Chicago é o maior exemplo. [...]. No Brasil verifica-se hoje o mesmo movimento. O urbanismo não ficou apenas no Rio com os projectos do prof. Agache, nem em São Paulo, concretisados nas visões intelligentes de Anhaia Mello [...], a idéia de urbanismo se vae espalhando por todo o paiz. Agora mesmo, temos em mãos o contracto que a municipalidade de Natal, sob a direcção moderna do seu prefeito - um técnico formado nos Estados Unidos - acaba de fechar com uma de nossas autoridades urbanistas, afim de levantar a planta futura de Natal de 100 habitantes, ..."41
\end{abstract}

Este trecho do artigo revela-nos diretamente pelo menos três fatos: que os projetos e debates urbanísticos desenvolvidos nas duas metrópoles brasileiras eram as grandes referências para os planos desenvolvidos para as outras cidades do país, devido, também, a sua proeminência político-econômica; que o processo de modernização da cidade brasileira não se limitava a estes grandes centros, mas espraiava-se por todo o país, consolidando a ascensão e prevalência do meio urbano sobre o rural, processo este que teve início em princípios do século XIX e tomou corpo definitivamente durante a Primeira República; e, o início do predomínio da influência americana sobre o europeu, principalmente francês, no modelo de urbanismo praticado no Brasil.

E, indiretamente, há mais um fato a ressaltar do artigo de Dantas: a forma de inserção deste ideário internacional dentro das práticas urbanísticas no Brasil não aconteceu apenas através dos técnicos e profissionais do eixo Rio-São Paulo; muitas vezes, o processo ocorreu de forma direta, como no caso de Natal.

Embora as formas de zoning ${ }^{42}$ propostos para cidades como São Paulo, Rio de Janeiro e Natal, no final da década de 1920, sejam ainda rudimentares, exceção feita ao Plano Agache, deve-se entendê-lo como um instrumento urbanístico e administrativo voltado a regulação da construção dentro dos limites da cidade, e que tem como parâmetros o uso, a densidade e a altura de edifícios; ${ }^{43}$ porque, mesmo que muitas das tentativas para sua utilização no Brasil tenham se concretizado de forma pontual e/ou limitadas a um destes parâmetros, foi dentro desta concepção, de um modelo ideal de zoneamento, que o debate se moveu.

Este debate, que ocorreu de forma mais intensa, pelo menos, a partir de 1928, com as palestras de Anhaia Mello, mostra a estreita aproximação ao debate americano e às suas práticas. É um momento em que, mesmo na Alemanha - país onde se origina e se constitui

\footnotetext{
40 Ibid.

${ }^{41}$ Dantas, G., 1929, p.01; grifos nossos.

${ }^{2}$ A palavra em inglês ainda era de uso corrente à época; neste trabalho utilizamos as duas formas sem distinção.

${ }^{43}$ Mancuso, 1980, p. 17.
} 
como disciplina e prática urbanística no último quartel do século XIX- o zoneamento perdeu pouco a pouco a sua natureza original, seus condicionantes e implicações, assumindo por completo seu caráter técnico-projetual, "la zonificación se convierte en el instrumento principal para la organización urbana" ${ }^{44}$; mesmo assim, dentro de sua perspectiva reformista, mantinha-se como instrumento efetivo para que a administração municipal tivesse capacidade de intervir globalmente sobre a cidade. Ao contrário, a experiência americana, ao longo da década de 20, afastou-se cada vez mais de qualquer projeto reformista e, ao invés de realizar maior justiça social para as populações pobres "trancafiadas nas habitações coletivas de New York e Chicago", tratou de mantê-las afastados, fora do centro e das áreas nobres da burguesia. ${ }^{45} \mathrm{O}$ zoning, regulando o uso dos terrenos e dos edifícios, assim como a densidade da população, somente não poderia atentar contra a propriedade privada. Como afirmou Basset,

“...zoning like other police power regulations must not transgress the rights of property owners guaranteed to them by the 'due process of law' provisions of state constitutions. If the zoning regulations do so transgress, they will be declared void by the courts". 46

É o discurso sobre a prática das cidades americanas, de ênfase nos aspectos e vantagens econômicas do zoning - com respaldo jurídico-constitucional, que repercute no Brasil, desde os escritos de Anhaia Mello e Prestes Maia, passando pelo debate carioca em torno da contratação de Agache e do seu plano até os intelectuais e técnicos que estavam pensando e intervindo na cidade do Natal deste período.

Inseriu-se, portanto, no contexto de modernização das cidades brasileiras, conformando-se ao projeto das classes dominantes, como um "novo código para garantir uma velha ordem", ${ }^{77}$ espacializando a segregação e desigualdade social. A elite brasileira não deixou de agir como o colonizador europeu do século XX na Ásia e África, que utilizou-se do zoning para erigir barreiras étnicas e sociais contra os nativos ${ }^{48}$.

Esboçar algumas questões sobre a forma de inserção do zoneamento, considerando mais as suas condições do que os seus modos, ${ }^{49}$ permite-nos entrever alguns aspectos deste projeto de modernização para as cidades brasileiras empreendido nas primeiras décadas do século XX. Há algumas indagações que podem auxiliar esta discussão. Por exemplo, quem são as pessoas que colocam a necessidade de implantação do zoning? Quais as contradições e conflitos que se manifestam na cidade e busca-se resolver com este instrumento urbanístico? A congestão urbana foi, nos casos da Alemanha (como fator de tensão social) e Estados Unidos (como fator de distúrbio para os mecanismos de produção de riqueza baseados no mercado dos solos), o ponto de partida para o desenvolvimento e aplicação do zoning. Poderíamos afirmar o mesmo para o caso brasileiro e, mais especificamente, para Natal? Embora formuladas para compreender os casos alemães e americanos, o mesmo questionamento para o caso brasileiro serve-nos, pelo menos, para entender o processo de transferência e adaptação do ideário urbanístico internacional.

Segundo Mancuso, as condições para fomento do zoning eram a grande cidade, como um fator produtivo, um bem econômico; a necessidade de conservar a propriedade privada do solo edificável - "la regulación por medio de la zonificación es la alternativa a la expropiación

\footnotetext{
${ }^{44}$ Ibidem, p. 276.

${ }^{45}$ Cf. Hall, 1995 , p. 68-72.

46 Basset, 1925, p.424.

47 Feldman, 1996.

48 Cf. Mancuso (1980, p. 13-15), sobre o primeiro congresso do Instituto Nacional de Urbanismo da Itália e o tema "urbanismo colonial".

${ }^{49}$ Como adverte Mancuso (Op. Cit.), considerar apenas os modos de inserção e uso do zoning restringiria a discussão apenas aos aspectos técnicos, sem indagar o contexto sócio-político e as motivações econômicas.
} 
generalizada"; o princípio de que todos teriam direito a construir, sendo necessária então a regulação da ação dos diversos agentes; e o desejo de salvaguardar os mecanismo de renda dos solos. $^{50}$

Contudo, mesmo partindo de pressupostos semelhantes, as experiências das cidades alemães desenvolveram-se em um caminho diferente daquele percorrido pelas cidades americanas. No primeiro caso, o zoning conformou-se como um modelo de cidade, perfeito para valorização das diversas partes que a compunham, permitindo a realização da grosstadt, a cidade grande; no segundo, tornou-se um mosaico de pequenas disposições locais que visavam a proteção das construções residenciais e dos valores do solo contra a intromissão prejudicial de determinado grupos sociais e de cor. Em ambos os casos procurou-se estender as formas de controle a toda a cidade, mas, enquanto na Alemanha esta busca correspondeu de forma efetiva a necessidade de parte do poder público em agir globalmente, nos Estados Unidos tornou-se a forma principal utilizada pelos grupos econômicos influentes para aprovar medidas que sanassem seus problemas locais e setoriais; por fim, "la adopción de medidas de regulación como la de la zonificación tiene un efecto [...] distincto en los dos contextos: a la realización de la ciudad al menos aparentemente eficiente, bella y ordenada, corresponde en América la ciudad segregada, protegida y corrompida". ${ }^{11}$

Portanto, é principalmente através da apropriação da forma de zoneamento americano que podemos compreender como este instrumento foi utilizado e adaptado à realidade brasileira, às práticas segregadoras que vinham sendo desenvolvidas desde o final do século XIX, revestindo este projeto de modernização com um véu de neutralidade e modernidade. Fato do qual não escapou a administração O'Grady.

\footnotetext{
${ }^{50}$ Mancuso, 1980.

${ }^{51}$ Ibidem , p. 333.
} 
Em junho de 1930, durante a exposição de urbanismo que ocorria paralela ao IV Congresso Panamericano de Arquitetos, a recém-formada engenheira Carmem Velazcos Portinho, representante do Rio Grande do Norte e única mulher a participar do evento, a convite do então presidente do estado Juvenal Lamartine, explanou e concedeu entrevistas a imprensa carioca acerca do Plano Geral de Sistematização de Natal, elaborado pelo arquiteto Giacomo Palumbo entre 1929 e $1930{ }^{1}$

Relembrando o seu artigo sobre a importância da aviação escrito para o Jornal do Brasil cerca de um ano antes, retomava o tema candente e tão caro ao discurso de modernização das elites dirigentes de Natal e do Rio Grande do Norte no final da década de 1920: sublinhando a demanda criada pela privilegiada posição estratégica de Natal, afirmava que finalmente a cidade tinha um plano que a permitiria estruturar-se para atender o fluxo de aeronaves que a colocavam como uma das chaves do sistema aeroviário da América do Sul, como o aeroporto tri-continental, unindo as Américas à África e à Europa. ${ }^{2}$

Natal seria subdividida, segundo a descrição de Carmem Portinho da proposta de zoneamento do Master Plan de Palumbo, em bairro comercial (reforçando a função terciária da Ribeira), administrativo, residencial, jardim e operário, além dos locais para o porto fluvial e ao aeroporto.

O bairro operário, possivelmente numa proposta de reestruturação do bairro popular do Alecrim, existente desde o final do século XIX (oficialmente desde 1911), surgiria da remoção das precárias casas dos operários e das classes mais pobres que existiam junto ao cais, na entrada da cidade e nos terrenos baldios que tanta má impressão causavam aos visitantes que em Natal aportavam. ${ }^{3}$ Como indenização, os novos habitantes do bairro construído "um pouco afastado do centro" receberiam da prefeitura "um lote de terreno e uma planta para a edificação de um lar simples de acordo com as pessoas da família" e outras facilidades para a construção; ademais, os operários só poderiam ter vantagens na mudança para um local higiênico, arejado, que obedecia aos "cânones" da urbanística moderna, ao invés da situação precária e insalubre, um local que também seria "um bairro jardim, havendo uma faixa de terreno em cada lote para plantação em frente da casa". ${ }^{4}$

\footnotetext{
${ }^{1}$ Embora $A$ República, se referisse à jovem engenheira como uma colaborada na elaboração do Plano, sabe-se hoje que Carmem Portinho não trabalhou no seu projeto; apenas apresentou no Rio de Janeiro (Cf. Portinho, 1999).

2 Embora o aumento da autonomia de vôo permitisse às aeronaves cobrir maiores percursos com um menor número de escalas e, com isso, fizesse, na década de 1930, refluir o discurso que vinculava a necessidade de reformas e modernização do espaço urbano às demandas da aviação, a entrada do Brasil na Segunda Grande Guerra confirmou a importância geopolítica de Natal para as rotas aeroviárias internacionais, com a construção da maior base militar americana fora dos EUA entre 1942 e 1945. Cf. Cascudo, 1947, Lenine Pinto, 1976, e as rotas da Panamerican Airways, na revista Aviation, Oct. 1941.

${ }^{3}$ Lamartine, 1930.

${ }^{4}$ Portinho, 1930.
} 
Além desse, haveria um bairro jardim de fato, "em moldes semelhantes aos ingleses", diria a jovem engenheira, que esfarelaria os arruados das Rocas, Areial, Limpa, Canto do Mangue, Chama-maré e outros assentamentos populares na área delimitada pelo rio Potengi e pelo oceano Atlântico. Nesse bairro, chamado por Câmara Cascudo de "Cidade das Dunas" uma recriação de apelo mais envolvente ao imaginário local, da mesma forma que o jardim o era para o inglês-, seria "feito o 'zoning' moderno, sendo evitada a superlotação e sendo os habitantes convidados a se pronunciarem sobre a administração do seu bairro, fixando o número e a localização de lojas e armazéns. Largas avenidas serão rasgadas, indo terminar no Boulevard de contorno que parte do cais do porto, margina o rio e o Oceano".

Sem dúvida, as propostas apresentadas pela jovem engenheira poderiam ser vinculadas ao ideário original propugnado por Sir Ebenezer Howard em 1898 e, com pequenas alterações - a principal em seu próprio título, reafirmado em 1902: o controle do crescimento da cidade, a estruturação de uma de suas partes como uma incipiente unidade de vizinhança, ${ }^{7}$ com atividades e usos complementares à função residencial, a autogestão, ou, melhor para o caso de Natal, o incentivo à participação dos moradores nos destinos do espaço urbano em que viviam, enfim, um projeto que abarcava a cidade como um todo, interligava e conferia unidade às suas partes.

Contudo, e aqui começamos a esboçar algumas questões que pretendemos discutir neste capítulo, essas propostas são atributos únicos e exclusivos da proposta cidade jardim? $\mathrm{Ou}$, mais ainda, seriam essas propostas suficientes para filiar um projeto ou plano urbanístico ao ideário howardiano ou à tradição Garden City? Afinal, Munford já o lembrou, a proposta de cidade-jardim reintroduziria o conceito grego de um "limite natural do crescimento", e, como o próprio Howard afirmou, nada de original havia nos elementos de sua proposta, salvo a combinação única das diversas idéias que lhe influenciaram, em direção a um projeto social de transformação pacífica, mas radical, da sociedade. A partir dá, poderemos abrir alguns questionamentos sobre a forma como esse ideário foi apropriado e desenvolvido, principalmente no Brasil, e como a historiografia tem lido e analisado esta proposta urbanística tão distante, a princípio, da corrente hegemônica vinculada À Carta de Atenas.

O caminho pacífico da proposta reformista de Howard, já explicitada na epígrafe de J.R. Lowell, The present cirisis, ${ }^{8}$ seria uma visão ou caminho oposto à destruição criativa inerente à modernidade "fáustica", na leitura de Berman?" não seria uma antípoda às formulações modernas frente às demandas e exigências geradas desde o século XVIII pela emergência dos processos sociais e econômicos do capitalismo? demandas de alto custo humano que configuram o caráter trágico do fausto goethiano? A formulação howardiana de conciliação entre o campo e a cidade é, por isso, como quer Tafuri, uma ideologia regressiva, uma "utopia da nostalgia" fundada no pensamento anti-urbano ${ }^{10}$ Considerando a disseminada apropriação do tipo urbanístico cidade-jardim no Brasil, essas perguntas levam-nos, invariavelmente, a discussões ainda mais fecundas sobre o seu caráter de moderno e da modernização do espaço urbano.

O objetivo seria, então, uma tentativa de alinhavar as discussões historiográficas que abordaram as diversas realizações que, de variadas formas, estão vinculadas à tradição garden city, procurando compreender a maneira como os planos e projetos urbanísticos que assumiram este epíteto - ou que lhes foi outorgado - foram lidos e interpretados, para estabelecer alguns parâmetros que permitam a resposta à pergunta inicial. Assim, que se faça

\footnotetext{
${ }^{5}$ Cascudo, $1929 \mathrm{~b}$.

${ }^{6}$ Portinho, 1930.

7 Embora Portinho e, muito menos, Howard não tenham utilizado tal termo.

8 "We ourselves must Pilgrims be,[...], Nor attempt the Future's portal with the Past's blood-roosted key" (retirado da $3^{\mathrm{a}}$ ed. inglesa, de 1946).

${ }^{9}$ Berman, 1986.

${ }^{10}$ Tafuri, 1984, p. 23.
} 
logo a ressalva de que esta leitura é incompleta e, mesmo, inconclusa, embora aborde alguns autores que são fundamentais para entender os desdobramentos do movimento pela cidadejardim e o próprio registro e interpretação das suas realizações, como F. Osborn, L. Munford e P. Hall, mas deixa outras de lado; lacunas estas que podem comprometer o cerne do esforço desse capítulo pela compreensão das chaves de leitura necessárias ao entendimento desta tradição urbanística (e político-social) e dos termos que muitas vezes substantivaram os tantos exemplos ao redor do mundo ocidental e oriental: "deturpação", "equívoco", etc.

Mas, afinal, qual a essência - se couber este termo - do pensamento howardiano? quais as prerrogativas que estruturam a sua proposta formulada em 1898, ponto nodal de todo o desenvolvimento do movimento pela cidade-jardim? É importante que se faça a distinção, como assumimos neste trabalho, entre o fulcro da proposta de Howard - que, embora o próprio autor assim não o desejasse, pode ser lida como um dogma - e a tradição Garden City que a partir daí se desenvolve, incorporando elementos diferentes em cada país e por cada grupo ou profissional que a fomentou, incluindo-se aí próprio Howard. Distinção esta que sirva de baliza para podermos avaliar as diversas leituras em torno das obras vinculadas a esta tradição.

Osborn, em "A Note on Terminology” para a $3^{a}$ edição inglesa do livro de Howard, propôs uma síntese que exprimisse o verdadeiro significado das formulações de 1898, baseado numa definição adotada pela Garden Cities and Town Planning Association em 1919: "A Garden City is a Town designed for healthy living and industry; of a size that makes possible a full measure of social life, but not larger; surrounded by a rural belt; the whole of the land being in public ownership or held in trust for the community". Como o próprio Howard foi consultado para esta espécie de verbete, vemo-lo enfatizando o caráter urbano de sua proposta, a necessidade do cinturão verde agricultáveis e da propriedade pública da terra. ${ }^{11}$

$\mathrm{Na}$ mesma edição, Munford também enfatizaria o caráter urbano da proposta de Howard, "a more integrated foundation for an effective urban life", cujas características seriam: a provisão de um cinturão verde permanente, destinado à agricultura e funcionando como uma muralha horizontal para contenção do crescimento físico da cidade; o controle e a propriedade permanente do solo municipal, revertendo à própria municipalidade todo incremento advindo da valorização fundiária; a limitação de densidade demográfica; e a estruturação de uma rede de cidades que formariam a Cidade Social. ${ }^{12}$

Em 1961, a leitura mais acurada de Munford ressaltaria o cinturão verde como um dos elementos essenciais da cidade-jardim - o termo Green Belt City seria então muito mais apropriado do que o epíteto de 1902 Garden City, que logo revelou-se infeliz, afinal a existência de jardins na cidade não era o seu elemento diferenciador - e revelaria a dimensão transformadora da proposta de Howard. Conquanto Kropotkin o antecedesse e o antecipasse na abordagem para enfrentar o processo de congestão das cidades, antes mesmo da invenção das modernas técnicas e tecnologias de transporte, comunicação e circulação, seria Howard quem daria o grande passo da reação "contra o êxodo suburbano e, ao mesmo tempo, contra o congestionamento metropolitano que o promoveu". Processo este de duas mãos, causa e efeito da perda da dimensão pública da cidade, "última fase da derrocada da cidade", espaço e lar - o subúrbio - de uma sociedade fragmentada que "existe apenas em si e para si mesmo". Era contra este monstro urbano, que afinal se consolidaria no segundo pós-guerra, principalmente nos Estados Unidos e naqueles países que seguiram padrão semelhante de (sub)urbanização, como o Brasil, que estava a insurgir-se Howard com o seu libelo revolucionário e pacifista, preconizando uma "vida local mais responsável e responsiva",

\footnotetext{
11 Osborn, 1949, p.26.

${ }^{12}$ Munford, 1949, p.34-5; a leitura do green belt como uma muralha horizontal verde é feita no seu "A Cidade na História", de 1961.
} 
igualando as vantagens sociais entre as metrópoles e as comunidades menores, ${ }^{13}$ enfim, realizando a promessa socialista, ou, mais ainda, moderna, desfazendo a cissão e oposição entre cidade e campo, assim como de todos os males daí decorrentes. ${ }^{14}$

Dessa forma, tentaremos delinear os elementos essenciais que estruturam a sua proposta e devem servir de parâmetro para a compreensão dos seus desenvolvimentos ulteriores.

1) a sua proposta é por uma nova estruturação urbana da cidade industrial, e não uma visão idílica de volta ao campo ou uma fantasia idealizada da "vida em cidadezinhas tradicionais", cuja tragédia goethiana de Gretchen deve sempre lembrar-nos da "crueldade e brutalidade de tantas formas de vida que a modernização varreu da face da Terra"15 - a leitura sobre as desvantagens do imã campo deveria desfazer qualquer possibilidade de vê-lo como uma utopia incoerente à modernidade; ${ }^{16}$ a sua contraparte capitalista já havia se exaurido e não era mais eficiente, nem viável social e economicamente, e a cidade-jardim surgia como a forma superior mais racional para fundação de uma nova cidade e para reforma das antigas;

2) essa cidade - que não era a cidade-jardim isolada, mas a rede que conformaria a grande Cidade Social - deveria ser pensada como um todo, como uma unidade que cresce por partes, harmoniosamente, como um flor ou uma árvore, ${ }^{17}$ a metáfora organicista e a possibilidade de antever e direcionar os processos de crescimento futuro estão na raiz da moderna disciplina urbanística e, não à toa, a proposta de Howard, ao lado da de Geddes, ajuda a consolidar a visão de planejamento regional a partir dos anos 20;

3) contudo, a possibilidade de gerir os destinos da cidade não deveria estar nas mãos de uns poucos tecnocratas, mas da maioria da população que, mesmo tendo um Conselho Geral para a administração municipal, deveria ser estimulada - o espírito e a dimensão pública da vida na cidade - para se organizar, quer em cooperativas, quer em iniciativas individuais, fomentando as iniciativas pró-municipais. E, enfatiza, quanto maior a participação e espírito públicos nas lides municipais, maior a possibilidade de atingir um padrão nunca antes alcançado de bem-estar social, fundado "nas vantagens econômicas, sanitárias, sociais da propriedade comum da terra"; 18

4) a propriedade apriorística e pública da terra, antecedendo os processos sociais de valorização fundiária, mas não os evitando, ao contrário, revertendo-os à própria municipalidade, é fundamental para a formulação da cidade-jardim; exacerba assim a sua oposição ao modo de produção capitalista, para o qual não foi proposta, combatendo os processos de especulação imobiliária e de apropriação privada da valorização social da terra: era o cerne de uma forma superior de organização econômica e social

\footnotetext{
13 Munford, 1998, p.555-566; sobre as ressonâncias contemporâneas das impecrações contra os males urbanos da suburbanização, cujos tentáculos ainda fazem muitos planejadores perderem o sono, principalmente os norte-americanos, Cf. Katz, 1994, e a sua coletânea de textos, especialmente o de Vicent Scully, "Architecture of Community".

${ }^{14}$ Uma das medidas da revolução socialista, proposta no "Manifesto Comunista" de Marx e Engels (1848), era a "organização conjunta da agricultura e da indústria, com o objetivo de suprimir paulatinamente a diferença entre cidade e campo" (Marx e Engels, 1998, p.28).

15 Berman, 1986, p.60.

16 Howard, 1996, p.109-10.

${ }^{17}$ Ibid., p.135.

18 Ibid., p.159.
} 
que se ergueria - aqui retomando este tema de tradição socialista - das ruínas do próprio capitalismo, no caso, o campo depauperado pela depressão econômica;

5) mesmo revolucionária em essência, a sua proposta prescinde de medidas revolucionárias de expropriação e de luta, porque seria vão lutar por forma de riquezas já ultrapassadas, daí suas constantes diatribes aos socialistas. É inerente a sua proposta o pacifismo, o caráter reformista de transformação social que se impõe pela força do melhor exemplo;

6) conquanto reconhecesse que todos seriam em certa medida comunistas ou socialistas, a sua crítica a esta alternativa revolucionária funda-se na leitura de que esses sistemas preconizariam um Estado centralizador e burocrático - esta forma moderna de maldade ${ }^{19}$-, impedindo a livre iniciativa, o individualismo que é inerente à natureza humana. Mas apesar da crítica ao Estado, como forma de governo centralista, e a sua constante incredulidade em relação a sua capacidade de ação, Howard não achava que ele fosse desimportante ou prescindível na sua proposta: a sua analogia entre a cidade-jardim e a empresa ferroviária mostra a necessidade da intervenção dos "poderes legislativos" na viabilização da expansão do empreendimento; a ingerência estatal também é fundamental para garantir as benesses da concorrência, evitando o monopólio e a irracionalidade na produção e relações sociais de trabalho, através do "princípio da opção local". ${ }^{20}$

7) Por fim, a possibilidade de controle do crescimento físico da cidade, com os cinturões agricultáveis delimitando e separando uma cidade da outra e com a fixação do número de habitantes. Contudo, que não se tome a sua proposta de 32 mil habitantes do seu experimento como um limite fixo e dogmático, pelo próprio caráter prototípico proposto e pela não explicitação do porquê deste número, cujas raízes históricas podem estar na capital da Utopia de Morus ou no grupo de cidades propostas por Leonardo da Vinci para acabar com a congestão de Milão; ${ }^{21}$ o importante era a configuração de uma grande cidade através da rede de cidade conectadas por um eficiente sistema de transporte, baseado na ferrovia, com todas as vantagens sociais da vida urbana e da proximidade à natureza.

\section{“Apostasias" na leitura da cidade-jardim}

O capítulo do livro de Peter Hall, cujo título já revela um claro tributo a Howard, destinado ao desenvolvimento da tradição cidade-jardim é um desfile de apocrifias e apostasias em relação ao "credo" original. Contudo, como é lembrado em sua própria introdução, "transplantadas no tempo e no espaço, bem como no meio sociopolítico, não é de admirar que [as realizações a partir das formulações originais dos muitos visionários, como Howard e Geddes] produzissem resultados amiúde bizarros e, vez por outra, catastróficos"; ${ }^{22}$ e é lido de forma irônica que um dos primeiros a cometer tais descaminhos tenha sido um dos braços direitos de Howard, que, ao lado de Barry Parker, ajudou a dar forma ao conteúdo preconizado para a cidade-jardim. Além do projeto de 1909 para Hampstead (entre outros tantos subúrbios elaborados em parceria com Parker para a Co-Partnership Tenants Housing Company em Cardiff, Leicester e Stoke-on-Trent), Raymond Unwin cometeria "o que para

\footnotetext{
${ }_{19}$ Berman, 1986, p.67.

${ }^{20}$ Howard, 1996, p.155, 185-86,

21 Osborn, 1949; Munford, 1949, p.29.

22 Hall, 1995 , p.04.
} 
muitos foi a grande apostasia”, em 1912: a defesa da construção de sattelite-towns próximas aos municípios e dependentes deles para a obtenção de empregos, posição que alguns anos depois estaria entre as recomendações oficiais do programa do governo inglês de habitações populares do pós-Primeira Guerra formuladas pelo Comitê Tudor Walters - onde Unwin era um membro-chave -, sancionadas em 1919 e cujos resultados foram a construção de mais de um milhão de moradias, embora quase nenhuma dentro das cidades-jardins de Letchworth e Welwyn. A Garden Cities and Town Plannning Association só teria outra oportunidade semelhante mais de duas décadas depois e desta vez não permitiria a oportunidade evolar-se, apesar da invectiva de Unwin contra o movimento em 1938 ao afirmar que a grande contribuição de Howard havia sido a idealização do subúrbio-jardim. Mesmo assim, todo o esforço de Osborn, John Reith, entre outros, em prol das novas cidades inglesas teria destruído "a essência do plano de Howard, que era obter fundos para a criação de sistemas previdenciários locais autogeridos. [...]; da visão howardiana de cidade-jardim, a Inglaterra ficaria apenas com a casca, sem a substância". ${ }^{23}$

Contraditoriamente, Hall reconheceria que as quatro cidades criadas no condado de Hertfordshire (Stevenage, Welwyn, Hatfield e Letchworth), duas a partir do New Towns Act de 1946, estruturadas ao longo da "Great North Road e da principal linha norte de trens de Londres", eram uma composição muito próxima da "Cidade Social" formulada no capítulo XII de To-morrow. ${ }^{24}$ Ora, que apostasia permite tal realização!?

Há várias formas de aproximação ao texto howardiano e do seu legado para o planejamento urbano do século XX. Das críticas acerbas ao próprio conteúdo "utópico" da sua proposta de reforma social, como na pequena resenha irônica do The Times em 1898, ${ }^{25}$ ou mesmo a da Fabian Society, em 1898, acusando a proposta de fútil e impraticável, até a apropriação indébita do atraente título em empreendimentos de baixa qualidade urbanística à serviço apenas da especulação, dos quais o Brasil é repleto de exemplos. Contudo, interessanos observar as formas de difusão, as relações dos seus propagadores e realizadores, assim como a leitura historiográfica sobre os fluxos e refluxos da consolidação, ao longo do século XX, da tradição deste suposto discurso unívoco logo partido. Estão, assim, estabelecidas duas chaves de leitura sobre o tema: uma que questiona as próprias realizações e os motivos e interesses envolvidos que conformaram e moldaram a proposta original a cada realidade sócioeconômica e cultural e uma outra que dialoga com as interpretações e leituras da historiografia feitas ao desenvolvimento de qualquer cidade ou parte dela que guarde relações com o movimento pela cidade-jardim.

A primeira publicação a respeito do Master Plan de Palumbo incorreria num primeiro equívoco da historiografia acerca da leitura do legado da tradição howardiana: o vínculo estrito e direto entre aos esquemas gráficos (em especial os diagramas n. ${ }^{\circ}$ 3, Garden-City, ward and centre, e n. ${ }^{\circ}$ 7, Group of slumless-smokeless cities) do livro de Howard. Assim, o grande bairro jardim projetado para Natal, com seu grande parque central e as dez avenidas radiais que estruturavam os seus grandes quarteirões e o conectavam ao grande boulevard de contorno, transformou-se ipsis literis em fato contundente de um suposto vínculo estabelecido. ${ }^{26}$

Se o Plano para Natal pode ser vinculado a essa tradição, não o será por esse motivo. Em nenhum momento do livro To-morrow Howard faz menção à forma urbana que cada cidade-jardim deveria tomar. Muito ao contrário, os seus diagramas, que demonstram esquematicamente a disposição do seu invento prototípico, traziam sempre a ressalva: "Plan

\footnotetext{
23 Ibid., p.124-25, 130, 151-57; a crítica a Unwin está embasada na constatação de Osborn (1949, p.10) de que, paradoxalmente, um dos primeiros a entender o ideário howardiano, o próprio Unwin, tenha sido responsável pela cristalização do "pattern of the universal suburban development."

24 Hall, op. cit., p.154.

25 Beevers, 1988, p.01.

${ }^{26}$ Cf. Miranda, 1981; contudo, em seu livro mais recente (1999), desvincula e omite-se a discutir a sua leitura inicial e incorre em um segundo erro: estabelece outro vínculo direto do Plano de Palumbo às ditas idéias neo-platônicas do projeto de Christopher Wren para Londres no século XVII; esta leitura teria reflexos posteriores, como no texto de Santos (1998).
} 
must depend upon site selected" ou "plan cannot be drawn until site selected"; ademais, como já enfatizou Munford, Howard não precisou detalhes arquitetônicos ou urbanísticos na sua proposta porque não queria ver as questões essenciais que abordava confundidas ou misturadas a qualquer imagem visual. ${ }^{27} \mathrm{E}$, acrescente-se que, embora enfatizasse a primazia do sítio sobre o plano, não estava preconizando um "urbanismo pitoresco", de respeito à topografia, dos traçados sinuosos, da arquitetura de inspiração medievalista, etc.; ademais, como está indicado na variante à $1^{a}$ edição, as modernas técnicas de engenharia poderiam tornar obsoleta ou desnecessária esta primazia: “... à medida que avançam a ciência e a arte da engenharia, tornam-se em menor consideração os obstáculos naturais, e cada vez mais o intelecto se converte em senhor do problema, e o domina e o submete a serviço do homem". ${ }^{28}$

Ademais, freqüentemente essa vinculação formal, essa leitura dos aspectos lingüísticos de uma obra, cotejando aproximações e distanciamentos em função das balizas estabelecidas por Howard - o que ele não fez para soluções formais - ou pelo desenho de Letchworth, Hampstead, Welwyn e, no Brasil, pelos projetos de Parker para a Companhia City, leva ao obscurecimento das discussões e do contexto político-econômico de cada plano, como afirmou Tafuri:

\begin{abstract}
"Siempre será posible realizar um análisis puramente lingüístico de asentamientos como Radburn o los Greenbelt Cities del New Deal norteamericano. Pero un método como este - el único válido para dar cuenta de la obra de Melnikov o de Stirling - resultaía inadecuado para colocar correctamente aquellas propuestas en su propio contexto: que es el de la relación entre renovación institucional de la gestión económica de los operadores públicos y reorganización de la demanda a nivel de la construcción". ${ }^{29}$
\end{abstract}

Exacerbando tal postura, chegaríamos ao absurdo de vincular Howard às chamadas Naæi Garden Cities. Embora brutal, o processo de reordenação territorial da Polônia sob o III Reich utilizou elementos do repertório conceitual garden city. Organizaram violentamente uma nova subdivisão administrativa do território, buscando uma ordem territorial (raumordnung) ideal, através de uma nova relação estrutural entre as unidades de assentamento, o campo e a cidade, e substituindo a população existente pelos "racially pure Germans". ${ }^{30}$ O exemplo alemão de garden city durante a Segunda Guerra mostra uma intrincada trama de referências e influências que tornam sempre à proposta de Cidade Social de Howard, embora nunca como uma leitura de primeira mão. Proposta esta que, embora não fosse a sua preocupação original, ofereceu uma concepção mais elaborada e orgânica e para reorganizar a metrópole existente. ${ }^{31}$

A metrópole, ou mesmo a grande cidade, era vista como a fonte do declínio da raça germânica pelos nazistas. Até aí nada de novo, afinal a modernidade traz consigo a reação romântica à cidade, lugar deletério de degeneração social e humana, produtora de uma raça cada vez mais enfraquecida, como em Rosseau e em Carlyle. Nem mesmo Howard deixou de valer-se de argumentos semelhantes (citando Dean Farrar, Alfred Marshall e Edward G. Wakefield) ao denunciar os malefícios e desperdícios sociais, econômicos e principalmente humanos das grandes cidades, "sepulturas da compleição física de nossa raça", embora não tenha se referido diretamente ao eugenismo. A inspiração para o seu modelo de movimento migratório organizado, a Art of Colonization, de Wakefield, de 1849, era uma peça paternalista de organização social hierárquica que incorporava também incipientes motivos eugênicos em prol do melhoramento racial. ${ }^{32}$ Discursos semelhantes, e mais elaborados, estavam no cerne

\footnotetext{
${ }^{27}$ Munford, 1998, p. 559.

28 Howard, 1996, p.203.

${ }^{29}$ Tafuri, 1984, p.24.

${ }^{30}$ Fehl, 1992.

31 Beevers, 1988.

32 Howard, 1996, p.106, 147 e 170.
} 
das origens inglesas do movimento pela reforma rural, agrária, na Inglaterra do final do século XIX e facilmente descambariam para o racismo, misturando idéias eugênicas ao higienismo e ao controle social e vinculando o declínio das cidades ao inchaço populacional das "sub-raças" do campo. Muitos, não satisfeitos com propostas de inner colonization, preconizariam a emigração para as colônias inglesas d'além mar. ${ }^{33}$ Desnecessário é dizer que ideologias semelhantes, agraristas, anti-urbanas, fluiriam ao longo das primeiras décadas do século XX no Brasil, alimentando o debate intelectual, sobre a constituição de uma nação, e urbanístico, sobre o processo de modernização das cidades brasileiras. ${ }^{34}$

Novo e peculiar é a apropriação da idéia de cidade social de Howard e a sua transformação em um esquema geométrico a serviço dos interesses conservadores que defendiam uma ordem territorial orgânica. Esta interpretação tem raízes antes mesmo da publicação de To-morrow, na proposta da Die Stadt der Zukunft (1896), uma simbiose entre cidade-jardim e grande cidade, de Theodor Fritsch, tão similar graficamente à de Howard, que passa a acusá-lo obsessivamente de plágio. Descabidas acusações, que Howard não deu importância, evidenciadas na radical diferença entre os conteúdos sociais. "Fanático propagandista do racismo, Fritsch projeta uma cidade onde cada indivíduo sabe, de imediato, qual o seu lugar dentro de uma ordem social rígida e segregacionista". "35 Esse processo continuaria no início do século XX, com as versões simplificadas - e derivadas diretamente do diagrama da cidade social de Howard - de Eduard von Berlepsch-Valendas, em 1907, e de Gustav Langen, em 1911. "The diagram was completely stripped of its social reformist message and could become part of a more conservative project of territorial reorganization, involving the decentralization of surplus population from a big city, rather than its replacement as promised by Howard"; assim, em 1911, “... the garden city idea had been reduced to a mere repository of spatial-technical concepts". "Não deixa de ser irônico que onde a proposta de reorganização do território mais se aproximou da cidade social de Howard, embora invertendo os sinais, tenha ocorrido sob o III Reich. Ironias à parte, fato é que a Nazi Garden City já estava muito distante do conteúdo social da tradição cidade-jardim, o que, no mínimo, revela os perigos metodológicos no estabelecimento estrito de vínculos apenas formais, de desenho. Ademais, o movimento forçado de migração e colonização - ao invés da concepção de cidade como o imã que conjugaria as benesses da vida rural e da vida urbana, gerando um movimento migratório espontâneo - revelou-se um fracasso.

Além desse tipo de leitura que enfatizaria uma faceta inexistente na proposta de Howard - a de planejador físico ao invés de um ferrenho reformista pela reconstrução da sociedade -, há outros equívocos, cujas raízes estão na forma de difusão e, principalmente, "exportação" e "importação" do ideário, como a idéia de que Howard pregava um "planejamento-pradaria" de baixíssima densidade ou de que pretendia confinar as pessoas em pequenas cidades isoladas pelo campo. ${ }^{37}$ Contudo, talvez o equívoco mais difundido tenha sido a confusão estabelecida a partir da (falta de) distinção entre a proposta de cidade-jardim e de subúrbio-jardim.

Entretanto, a leitura um tanto dogmática de Hall, agrilhoada às palavras de Howard de 1898, leva a uma postura que o próprio precursor da teoria da Garden City não avalizaria. O seu espírito e caráter de inventor ${ }^{38}$ tinham muito claro o longo caminho a percorrer entre o esboço inicial e a construção final do experimento de sucesso. ${ }^{39}$ Havia muitas variáveis que escapariam à formulação ideal e que só poderiam ser confrontadas e enfrentadas na realidade. "Howard fez o que um engenheiro capaz faz hoje em dia, quando procura criar um novo tipo

\footnotetext{
33 Aalen, 1992, p.37-9.

${ }^{34}$ Cf. Campos, 2000; Lira, J.T.C., 1999; Ribeiro e Cardoso, 1996.

35 Hall, op. cit., p.133.

36 Fehl, 1992, p.91.

${ }^{37}$ Hall, op. cit.

${ }^{38}$ Como enfatiza Osborn, 1949, p.21-22.

${ }^{39}$ Cf. Howard, cap.IX, p.164-68.
} 
de estrutura cuja complexidade produz pressões e empuxos que são incalculáveis com base na experiência passada e nas formas tradicionais: criou um pequeno modelo e o experimentou". ${ }^{40}$ Esse primeiro protótipo foi Letchworth e muito já foi dito a respeito da primeira cidadejardim, inclusive a forma como o projeto de Parker e Unwin revestiu o conteúdo social da proposta howardiana e, a partir daí, tornou-se quase impossível distinguir um do outro, embotando o teor revolucionário que impregnava o texto de $1898 .{ }^{41}$

Todavia, esse desvirtuamento está muito mais vinculado às condições específicas de cada país e de cada época do que à "traição" de Unwin. Mesmo na Inglaterra, e apesar de todo o esforço da Garden City Association por uma legislação urbanística (que, num primeiro momento, refletiria-se no Housing, town planning, etc., Act de 1909), às vezes propugnando até mesmo aldeias e subúrbios jardins ao lado da proposta de cidades novas, o fenômeno da apropriação disseminada e do uso inescrupuloso do termo "cidade-jardim" por construtores e especuladores, sem nenhum vínculo às propostas, também se faria presente, assim como na França, no Japão e no Brasil. ${ }^{42}$

O caso da França talvez seja um dos mais pertinentes para cotejar à realidade brasileira. Primeiramente, porque é nesse ambiente que se forma o jovem arquiteto Giacomo Palumbo, alguns poucos anos antes das propostas de Sellier para Paris, em 1919; em segundo lugar, devido a imensa influência que o urbanismo francês irá exercer na estruturação dessa disciplina no Brasil, fosse por meio do Musée Social ou da contratações de técnicos estrangeiros, como Bouvard e Agache. ${ }^{43}$

Antes de mais nada, que se desfaça o mito do suposto "pecado original" que teria maculado a evolução da tradição garden city na França, fruto da indistinção entre a formulação de cidade-jardim e a de subúrbio-jardim: a "confusão elementar" originada em La Cité Jardin, de Georges Benoit-Lévy, de 1904, ${ }^{44}$ "confusão da qual os urbanistas franceses jamais puderam, daí em diante, desvencilhar-se. Ou talvez pensassem que o evangelho howardiano puro não funcionaria para o francês, esse ser incuravelmente urbano". ${ }^{5}$

A apropriação do ideário da cidade-jardim na França não foi limitada apenas a sua forte imagem ambiental, como aponta Gaudin, deslindando o contexto em que a proposta de Howard é importada e interpretada. Embora o grupo vinculado a esquemas paternalistas de controle social visse a proposta de Howard como uma herdeira das experimentações urbanísticas de alguns industriais do século XIX, interessando-se sobremaneira pela imagem de um assentamento de baixa densidade habitacional, que reteria de forma inequívoca as vantagens da vida rural em um estabelecimento industrial (ordenando a vida do trabalhador $\mathrm{e}$ enfatizando os valores familiares e a moralidade combinado a um alto padrão de salubridade), o grupo de reformadores ligados à social-democracia, à tradição socialista, incorporaram a essência do conteúdo social da cidade-jardim às suas lutas por padrões mais democráticos, não paternalistas, de habitação social, planejamento urbano, administração, cooperativismo e solidariedade local e até mesmo pela nacionalização (ou municipalização) da terra, escopo fundamental para o interesse de mudanças mais pragmático e gradual desse grupo, ao contrário daqueles ligados ao Parti Ouvrier Français, descrente das questões políticas locais e a favor da luta "radical" de classes e do esforço pela tomada do poder central. ${ }^{46}$

\footnotetext{
40 Munford, 1998, p.558.

${ }^{41}$ Hall, op. cit.

42 Cf. Andrade, 1998; Hall, 1995; Gaudin, 1992; Watanabe, 1992, e Ward, 1992.

43 Pechamn, 1996; Leme, 1999.

${ }^{4}$ Ele publicaria logo em seguida o livro Les cités jardins d'Amérique (1905); os dois livros foram embasados em viagens de estudo financiadas pelo Musée Social. Este, fundado em 1894, e que foi o principal abrigo desse considerado grupo paternalista, "sponsored much of the earliest interest in the garden city idea in France..." (Gaudin, 1992, p.53).

${ }^{45}$ Hall, op. cit., p.133.

${ }^{46}$ Gaudin, 1992, p. 53-57.
} 
Mesmo assim, os pouco exemplos de cités jardins desenvolvidos no entreguerras estavam distantes da proposta original de Howard, fosse por causa dos padrões de assentamentos paternalistas, interessados na chamada garden bousing e em reformas para proteger os valores familiares tradicionais, ou mesmo pelo "limites pragmáticos das iniciativas municipais progressivas", aproximando-se do padrão unwiniano de subúrbio-jardim. Mesmo assim, Howard foi a base fundamental para os planos para a região metropolitana de Paris, com os pequenos garden settlements da década de 1920, como Les Lilas, Drancy e Suresnes, ou as cités jardins maiores da década de 1930, como Châtenay-Malabry e Plessis-Robinson. Contudo, mesmo os exemplos maiores não puderam ser articuladas como verdadeiras cidadesjardins, devido à baixa densidade de "cottage housing", à falta de emprego e à inadequação das conexões do sistema de transporte público. ${ }^{47}$

\footnotetext{
"However the drif away from the original model appears more serious in France than among European neighbors such as Germany or Belgium or even some distant countries like Australia, if less serious than in Japan. But we should not make the mistake of seeing the garden city as merely a design reference in France". 48
}

Assim, mesmo limitada, não foi a apenas como um repertório de "environmental imagery" que a proposta Garden City chegou à França. A ênfase no cooperativismo e na abordagem localista para a reforma urbana e social, reforçando a tradição francesa do autogoverno local, e, principalmente, aquilo que mais rapidamente foi desconsiderado em outros países, a idéia de Cité, "undestood as a community pattern and citizen matrix", que está na raiz do desenvolvimento dos esquemas de bem-estar social e da promoção do town planning, foi o que atraiu tanto os reformadores burgueses como os sociais democratas. A cidade-jardim oferecia então uma alternativa viável para um modelo orgânico e ordenado de Citée. ${ }^{49}$

\section{A cidade novíssima das dunas}

No Brasil, a mesma questão sobre a deturpação do ideal howardiano pelos subúrbios jardins, no caso, o bairro-jardim, está no cerne da discussão acerca do significado dos projetos de loteamento da City em São Paulo, principalmente aqueles projetados por Barry Parker.

Conquanto o seu "aspecto de garimpeiros do faroeste americano", de não-cidade de habitações precárias e bairros desconexos, submetida a um processo especulativo desenfreado, com o qual, muitas vezes, o poder público era conivente, formasse a São Paulo que recebia o gigantesco afluxo de (i)migrantes que acorreram à capital paulista nas primeiras décadas do século XX, essa ainda tinha os seus encantos nos anos 1920.

\footnotetext{
“... a paisagem urbana mantinha algumas relações básicas com o quadro natural, dando ao conjunto um atmosfera de fugaz alumbramento. [...]. A população em geral, as famílias e os jovens nubentes manifestavam a mesma fascinação pelo quadro natural em que se amoldava a cidade e, nos fins de semana, era intensa a procura de recreação, repouso e romance nos jardins naturais..." 50
}

Essas imagens idílicas, paisagem tropical de sua "única herança tradicional", eram quebradas e substituídas por uma "ornamentação paisagística européia", e assinalavam uma mudança radical na identidade da cidade. A gigantesca "holding internacional City of São

\footnotetext{
47 Ibid.

48 Gaudin, 1992, p.60.

${ }^{49} \mathrm{Ibid}$.

${ }^{50}$ Sevcenko, 1992, p.112.
} 
Paulo Improvements and Freehold Land Co., responsável pelo empreendimento imobiliário das cidades-jardins, adulteração comercial do modelo urbanístico original e revolucionário de Ebenezer Howard na Inglaterra", estava no centro deste processo de modernização, com o projeto de desbastamento do bosque tropical da Avenida Paulista. ${ }^{51}$ "Esse quadro, [...], foi completado pelo entusiasmo 'yankee' da Câmara Municipal, fazendo votar, contra qualquer bom senso, o projeto que impunha artificialmente a fantasia moderna da verticalização do centro da cidade". ${ }^{52}$

A imagem de qualidade ambiental e urbanística dos projetos de Parker para alguns bairros da cidade foi o aspecto de maior ressonância de sua passagem pelo Brasil, mas não foi o único: o seu esboço para um anel de parques, junção das idéias de avenida-parque e de greenbelt para a contenção do crescimento de São Paulo, teve influências nas propostas de Ulhôa Cintra, Saturnino de Brito e Prestes Maia na década de 20, ou mesmo nas propostas de unidade de vizinhança e de planejamento regional de Anhaia Mello a partir dos anos 30, embora aqui através das formulações americanas, do Plano Regional de New York de Thomas Adams que, por sua vez, remontam a Howard, a Letchworth e a Hampstead. Mas, talvez, a leitura de Victor da Silva Freire - engenheiro e urbanista com participação fundamental na administração pública de São Paulo na década de 1910, envolvido também com a City, onde foi diretor - da cidade-jardim como mera colônia, ou bairro residencial, reafirmando a tese de Unwin de 1909 e inserida dentro da busca do maior rendimento econômico da cidade e da contenção do crescimento exagerado da malha urbana, tenha sido mais significativa para os rumos tomados pelo crescimento de São Paulo. O desdém posterior de Prestes Maia (prefeito de São Paulo em dois mandatos, cujo "Plano de Avenidas", de 1930, foi determinante para a estruturação urbana da cidade até os anos 1960, pelo menos) ao modelo cidade-jardim, de interesse apenas intelectual - uma crítica direta a Anhaia Mello -, em oposição à defesa da metrópole e da sua característica de centralidade ${ }^{53} \mathrm{~A}$ contribuição de Parker, além do desenho dos bairros-jardins e da proposta do anel de parques - que, afinal, não foi uma simples transplantação do modelo urbanístico inglês, mas dos seus princípios de respeito ao sítio, à paisagem e à cultura pré-existente (a aproximação de Parker a cultura portuguesa já havia sido iniciada como os seus projetos para a Cidade do Porto, em 1915) -, ajudou a trazer à tona o ideário Garden-City e torná-lo uma importante referência no debate urbanístico, principalmente a partir dos anos 1930, com a consolidação do processo de metropolização. ${ }^{54}$

À maneira dos planos de Jorge de Macedo Viera - profissional influenciado diretamente por Barry Parker à época da City, cujos inúmeros trabalhos a partir de 1920 revelam claramente a sua filiação - para as cidades de colonização do norte paranaense, como Maringá, e do plano de Goiânia, o Master Plan de Palumbo para Natal concebe a área central da cidade de modo clássico, interligada à estação ferroviária a ao hidroporto no rio Potengy. A clara influência Beaux-Arts - de uma arquiteto formado na Escola de Paris e que, antes de fixar-se no Nordeste, trabalhou com o arquiteto neoclássico Heitor de Mello no Rio de Janeiro - presente no seu plano já estava claramente exposta na sua entrevista ao jornal A República, em fevereiro de 1929: defendia a abertura da cidade para o rio, que tão mal recebia os visitantes que por mar chegavam com suas fachadas feias e um minúsculo cais, propondo uma espécie de grande avenida-parque beira-rio-e-mar que partiria do cais Tavares de Lira, uniria-se ao Boulevard, circunscrevendo a cidade nos seus próprios contornos naturais. A reestruturação do bairro comercial da Ribeira, com retificações, alargamentos e a criação de novas avenidas axiais, revela esta influência de forma precisa.

A influência da tradição Garden City, advinda das mais variadas fontes - como o contexto francês de difusão das cités jardins em que Palumbo é formado, do City Beautiful e do

\footnotetext{
51 Ibid., p.114.

52 Ibid., p.116.

${ }^{3}$ Cf. Andrade, 1998.

${ }^{54}$ Ibid.
} 
Town Planning americano, ambiente de formação do engenheiro e prefeito Omar O'Grady, cuja influência no plano está explícita nos termos do contrato, ou no debate intelectual em torno dos projetos de reforma e modernização da cidade, cujo ápice seria o Plano Geral de Sistematização ${ }^{55}$ - revela-se na forma de concepção dos bairros residenciais de Natal, que deveriam ser transformados em "bairros jardins", segundo a própria expressão de Palumbo, "cortados aqui e ali de parques, que façam agradável a alegria de viver". ${ }^{56}$

$\mathrm{Na}$ Cidade Alta, núcleo original de ocupação da cidade, no bairro operário do Alecrim, nos já existentes bairros de Petrópolis e Tirol - originários da Cidade Nova, que Palumbo incorpora ao seu plano e a expande - e no novo bairro jardim, situado entre o oceano e o rio, seriam construídos parques e residências que respeitassem as exigências modernas de salubridade, estruturando-os em um "sistema de jardins públicos", adaptados ao clima, à terra e à necessidade de grandes sombras, para torná-la, no futuro, "uma cidade jardim". ${ }^{57}$

Ao novo bairro jardim, em particular, como já enfatizamos no início, embora propusessem a participação da população na sua gestão, fixando o número de armazéns e lojas comerciais e o número de habitantes, estava mais próximo à idéia de comissão do plano da cidade preconizado pelo urbanismo americano, do que a auto-gestão comunitária da cidadejardim howardiana. O seu desenho, assemelhado ao diagrama da Cidade Social, vincula-se mais à monumentalidade de um urbanismo de inspiração barroca, tendo como foco principal a sua grande praça central, para onde convergiriam as dez avenidas axiais que definem os quarteirões, ligando-a ao boulevard de contorno, ao bairro da Ribeira, à avenida-parque e aos acessos à Cidade Alta e à Cidade Nova. Ademais, tal proposta de participação da população estava muito distante da realidade política da Primeira República e, no máximo, teria uma representação hierárquica vinculada à estrutura oligárquica dos anos $1920 .{ }^{58}$

O projeto de Palumbo era, como está explícito em seu título, um plano geral que abarcava e estruturava toda a cidade, articulando suas partes e dando-lhe unidade urbana, constituindo assim a feição da cidade moderna do século XX em oposição à cidade do período colonial que, na visão de Câmara Cascudo, nem mesmo era cidade. A capacidade de previsão do plano, de preparar a cidade para o futuro e controlar e antever os seus processos sociais, antes de ser uma prerrogativa de Howard, está no cerne de toda a urbanística moderna. ${ }^{59}$ Em Natal, que se constituiu como cidade nestes anos da Primeira República, os problemas urbanos colocados pela modernidade estavam colocados, como os de circulação de mercadorias e de reformas dos espaços para atender a demanda dos novos ou mais evoluídos meios de transporte, o carro, o navio de maior calado e, principalmente, o avião - elemento central nos discursos em prol da modernização da cidade nos anos 20, excetuando, obviamente, os problemas inerentes às grandes cidades, à metrópole, como a congestão urbana e a escassez habitacional. Mesmo essa poderia tornar-se dramática por ocasião das grandes secas, como a de 1877 e a de 1904-05: os flagelados que afluíam à cidade praticamente dobravam a sua população, causando total colapso de abastecimento e serviços, o que colocava claramente a necessidade de uma perspectiva regional para enfrentamento deste problema secular. As colônias agrícolas construídas em 1877 e 1878 para desviar o fluxo de flagelados, mesmo dentro de esquemas paternalistas - que logo malograram pela falta de assistência e pela inépcia dos administradores -, poderiam ter evoluído com uma aproximação ao conteúdo social howardiano. Contudo, a realidade bem diversa da modernização no Brasil

\footnotetext{
55 Cf. Dantas, 1998; citando Unwin, Câmara Cascudo (1929b) diria, a respeito do Plano de Palumbo, que "urbanismo é justamente the science of linking up connection between things" e que um master plan não poderia ser como uma luva que se aplicasse perfeitamente à mão na primeira prova, ele exigia tempo, mudança e depuração.

56 Palumbo, 1929, p.01.

57 Ibid.

58 Cf. Dantas, 1998, e Soares, 1999.

${ }^{59}$ Collins e Collins, 1980.
} 
encaminhou-se para a construção - ou desconstrução - de cidades fragmentadas e segregadas. Resultado de causas e efeitos que Howard propunha-se a combater há mais de um século.

O Plano Geral de Sistematização pode ser vinculado diretamente à tradição Garden City, mas não ao ideal howardiano. Embora abarcasse a cidade como um todo, não estava inserido dentro de uma perspectiva regional de planejamento, não estruturava ou limitava o seu crescimento com um green belt - mas delimitava e enfatizava os seus limites naturais com a avenida-parque e o boulevard de contorno; e muito menos estava dentro de um projeto político de transformação social. Mesmo a proposta da Taxa de Benefício, vulgarmente conhecida como "imposto do calçamento", em moldes semelhantes ao benefit assessement do planejamento americano, amplamente debatida e criticada, e aprovada em 1930, que visava auferir recursos, por meio da taxação antecipada do processo de valorização fundiária, para uma municipalidade pobre de um estado pobre - quase monocultor, dependente dos humores internacionais em relação ao "ouro branco", o algodão -, não teve condições de ser implementada, devido às condições políticas adversas pós-outubro de 1930, que afastou O'Grady da prefeitura, assim como o seu projeto administrativo que, aparentemente, buscava uma maior independência política do município e continuidade de ações.

Talvez possa dizer-se que não houve nenhuma realização plena do modelo ou tipo cidade-jardim; entretanto, algumas avançaram, como os protótipos (a concepção inicial é esta mesmo) Letchworth e Welwyn e talvez a de maior sucesso tenha sido o planejamento de new towns inglesas pós 1946; mas isto não significa fracasso ou que a proposta de Howard esteja enterrada em definitivo, inclusive porque, como foi dito, o sucesso só viria depois de uma série de fracassos, como todo experimento científico. ${ }^{60}$ A série de "fracassos" de Howard inclui, influenciadas diretamente ou não, dezenas, centenas de cidades novas e assentamentos urbanos que, na sua maioria, possuem ótima qualidade ambiental e urbanística. ${ }^{61}$ As chamadas deturpações ou equívocos que, muitas vezes transformam-se em peças acusatórias da suposta inerente inviabilidade da proposta cidade-jardim - quando na verdade são o retrato cru dos "interesses estabelecidos" que estruturaram os (des)caminhos urbanos, e que Howard achava que poderia superar pela força do bom exemplo -, demonstram, isto sim, o processo de transferência e adaptação de ideários urbanísticos, os diversos interesses que se batem pelo controle do destino das cidades.

A assunção da viabilidade do subúrbio-jardim como única variante possível à metrópole, e não como uma das articulações possíveis para um projeto regional, é também revelador da forma como o ideário cidade-jardim foi apropriado, transformado logo em suas primeiras décadas de um projeto reformista de transformação social em uma esquema ambiental de desenho urbano. Contudo, se o subúrbio-jardim não estiver articulado a um projeto que abarque a cidade e a região, o processo de crescimento desenfreado das cidades, mesmo de porte médio, estará na iminência de pôr abaixo até a sua qualidade original, perdendo-se numa mancha urbana fragmentada. ${ }^{62}$

Desta forma, a tradição Garden City desenvolveu-se por várias ramificações a partir do ideário original, muitas vezes degenerando-se realmente em meros esquemas formais para grandes empresas construtoras. Entretanto, se as causas que motivaram a proposta de Howard ainda existem, e se ainda é possível pensar em mudanças e transformações sociais, revolucionárias em essência, então o ideário Garden City permanece atual, como um das bases para formulações de projetos que tornem outra vez visível o horizonte das promessas da modernidade.

\footnotetext{
${ }^{60}$ Howard, 1996, cap. IX.

${ }^{61}$ Cf. Ward, 1992.

62 Ibid.
} 


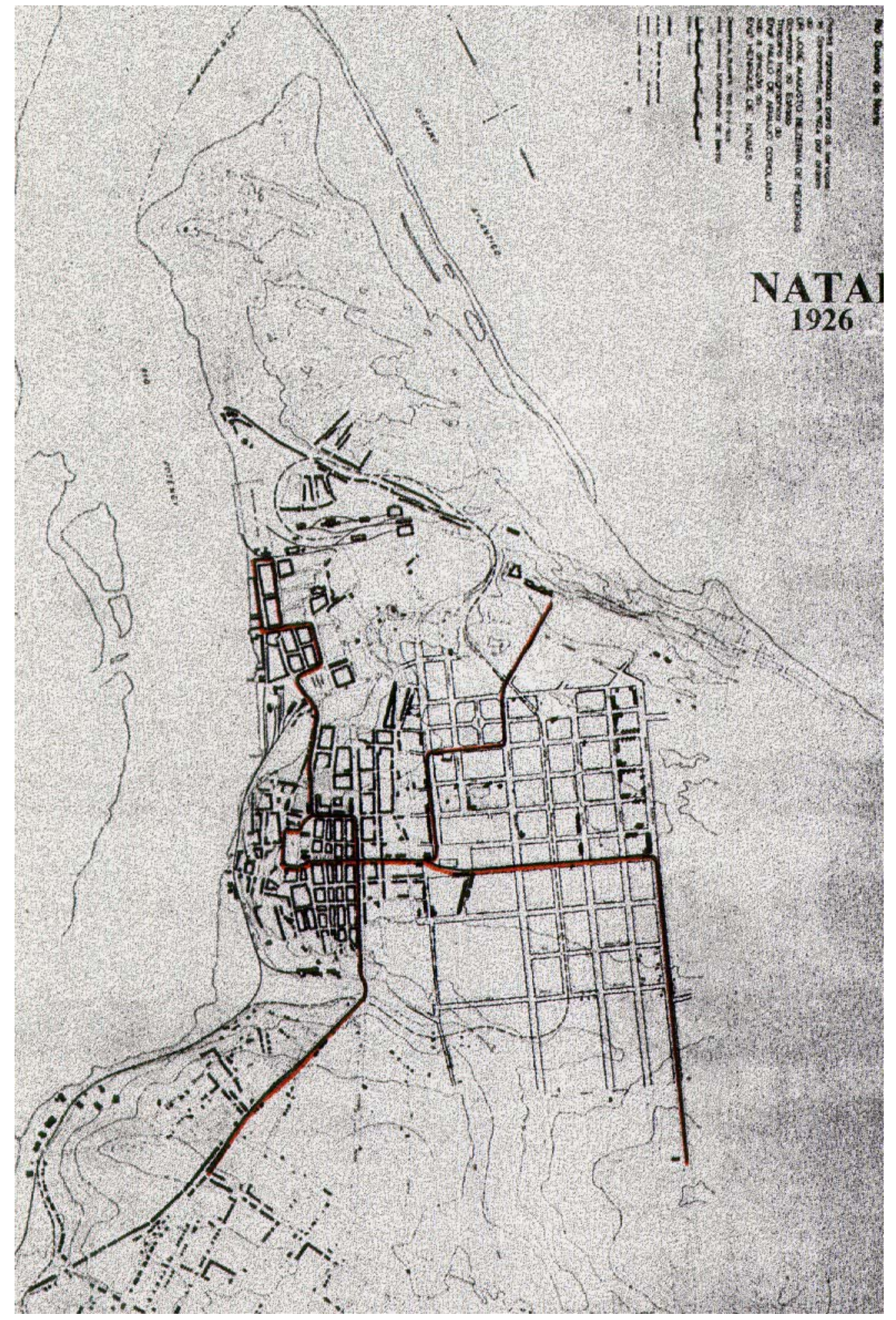

Fig. 4-01: mapa da cidade de Natal de 1924, organizada pela Comissão de Saneamento de Natal; em vermelho as linhas de bonde existentes na década de 1920; o reticulado da "Cidade Nova" está sobreposto ao desenho, mas nem todas as ruas indicadas tinham sido abertas ainda. Fonte: Ferreira, 1996. 
Linhas convulsas e tortuosas retificações: transformações urbanas em Natal nos anos 1920 


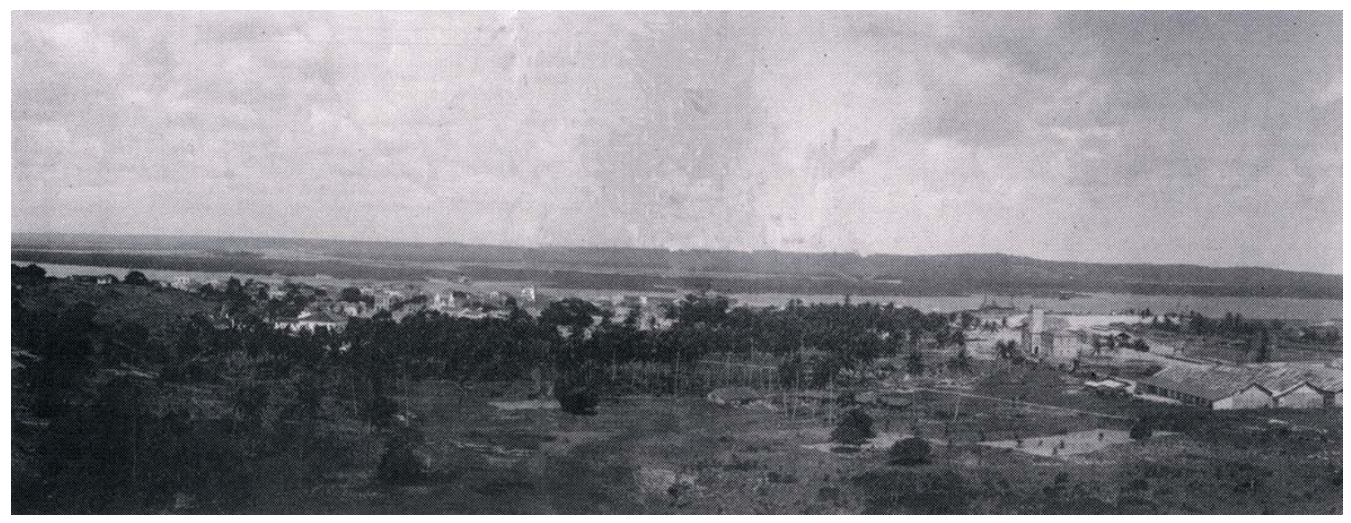

Fig. 4-02: Panorâmica dos bairros da Ribeira e Rocas, c. 1910s. Fonte: Lyra, 2001, p.24.

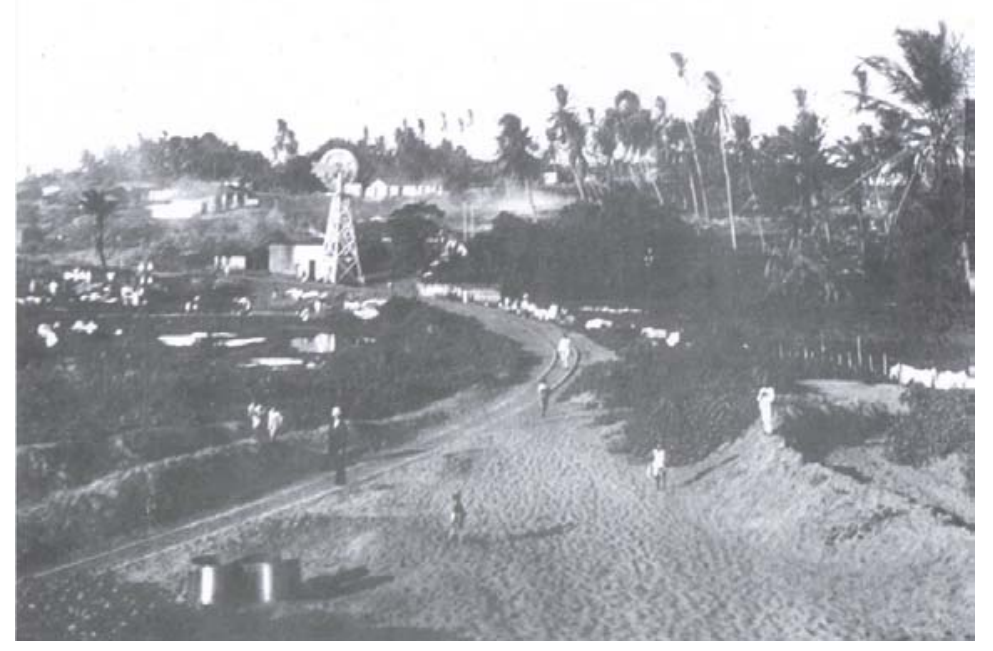

Fig. 4-03: Foto do Oitizeiro, onde localizava-se o terreno da Empresa Tracção Força e Luz; atualmente Avenida do Contorno, a Avenida do Saneamento projetada e executada pelo Escritório Saturnino de Brito a partir da idéia original contida no plano de saneamento e extensão de Henrique de Novaes.

$$
\text { Fonte: Lyra, 2001, p.53. }
$$

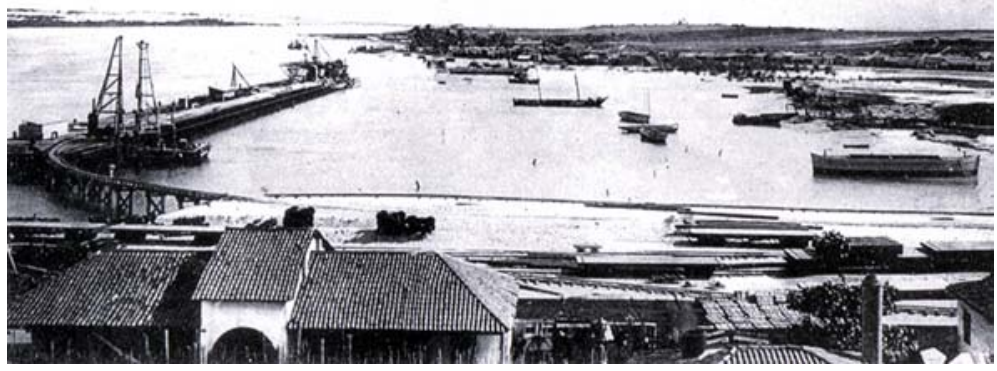

Fig. 4-04: "Panorama da Barra Dunas e ponte da Estrada de ferro central"; postal sem identificação; possivelmente dos anos 1910. Fonte: Lyra, 2001, p.58. 


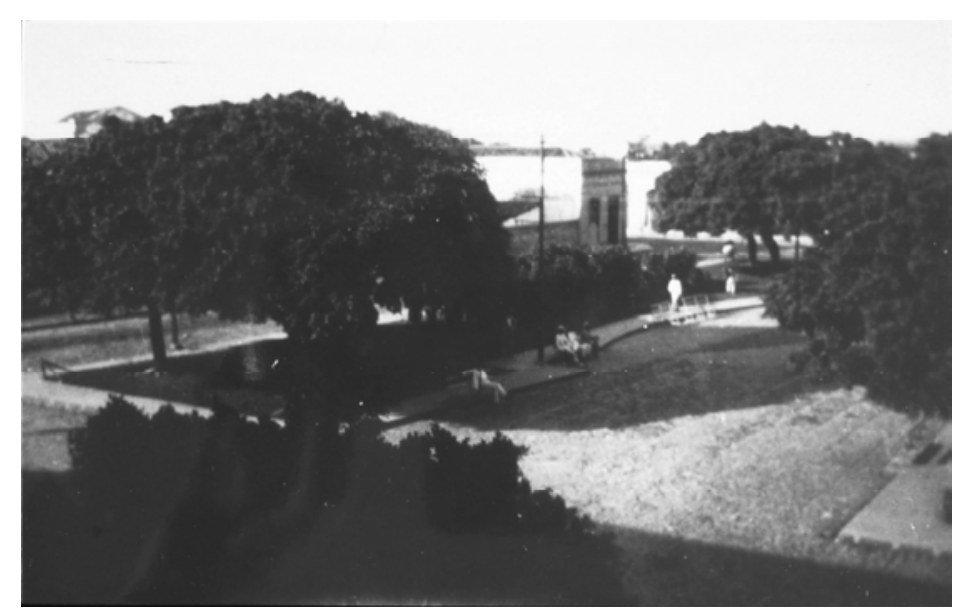

Fig. 4-05: Dez. 1928 - "Praça do Palácio/ Natal". Fonte: Acervo IEB/USP $(896-31 / \mathrm{B} / 3)$

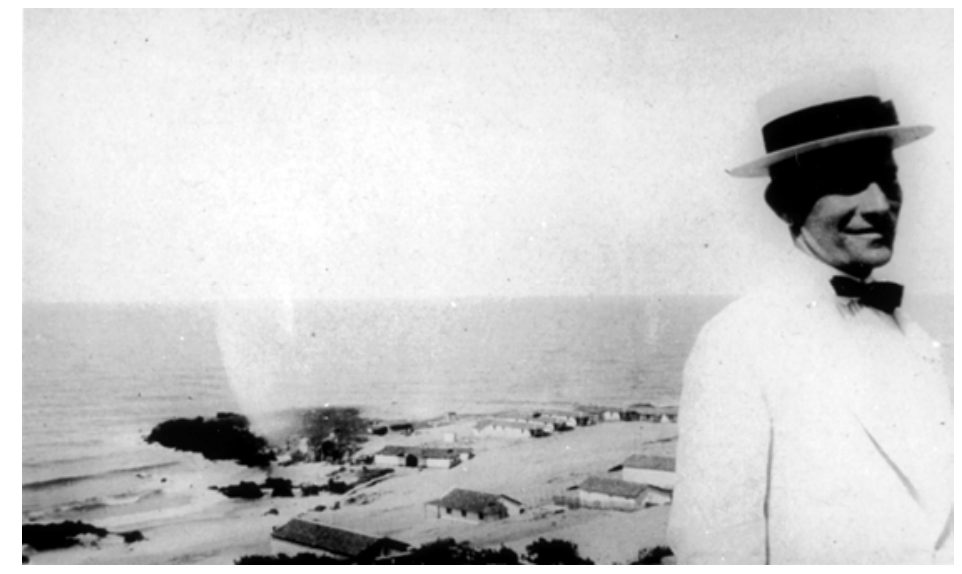

Fig. 4-06: 7/8/1927 - “Omar O'Grady ante praias/ natalenses". Fonte: Acervo IEB/USP $(606-16 / \mathrm{D} / 35)$ 


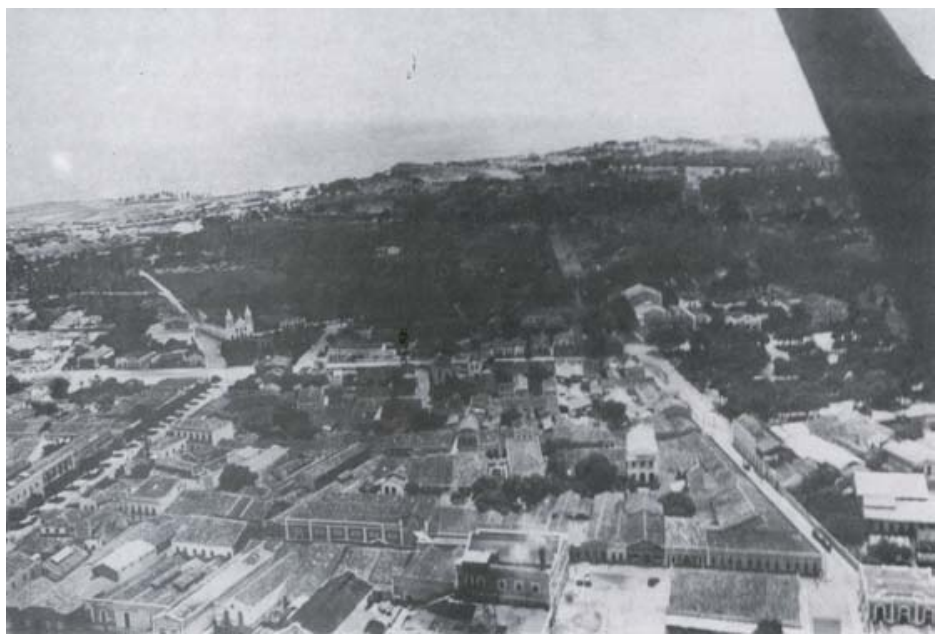

Fig. 5-01: Vista aérea de Natal em 1930; foto de João Galvão. Fonte: Lyra, 2001, p.21.

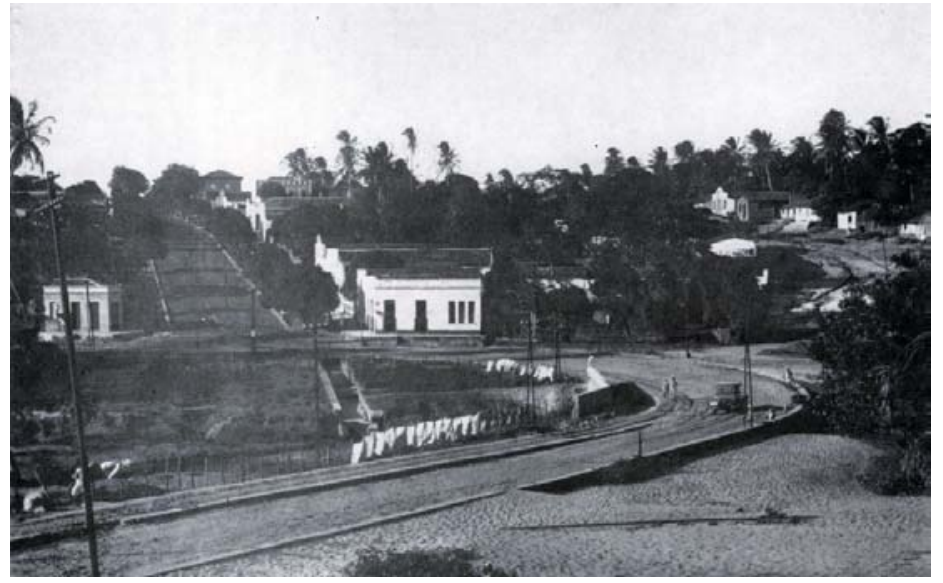

Fig. 5-02: Foto de João Galvão de 1930 mostrando a curva do Baldo, início da avenida Rio Branco, subida para a Cidade Alta para os que vinham do Alecrim. Fonte: Lyra, 2001, p.31. 


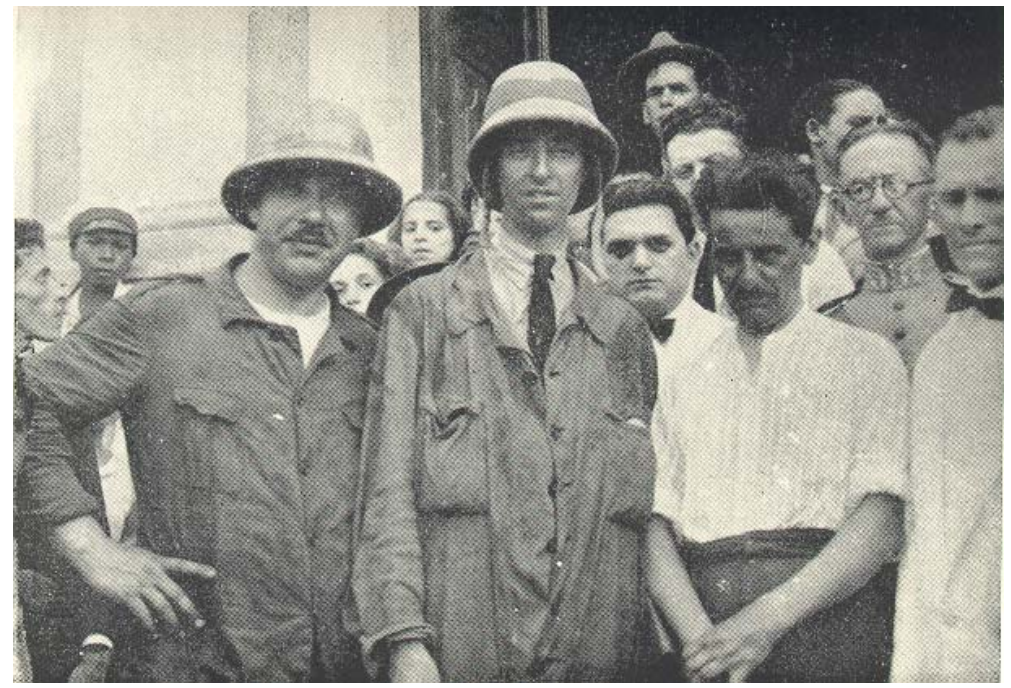

Fig. 5-03: Beires e Castilho, do avião "O ARGOS", com Câmara Cascudo e o engenheiro Omar O’Grady, em 1927. Fonte: Viveiros, 1974.

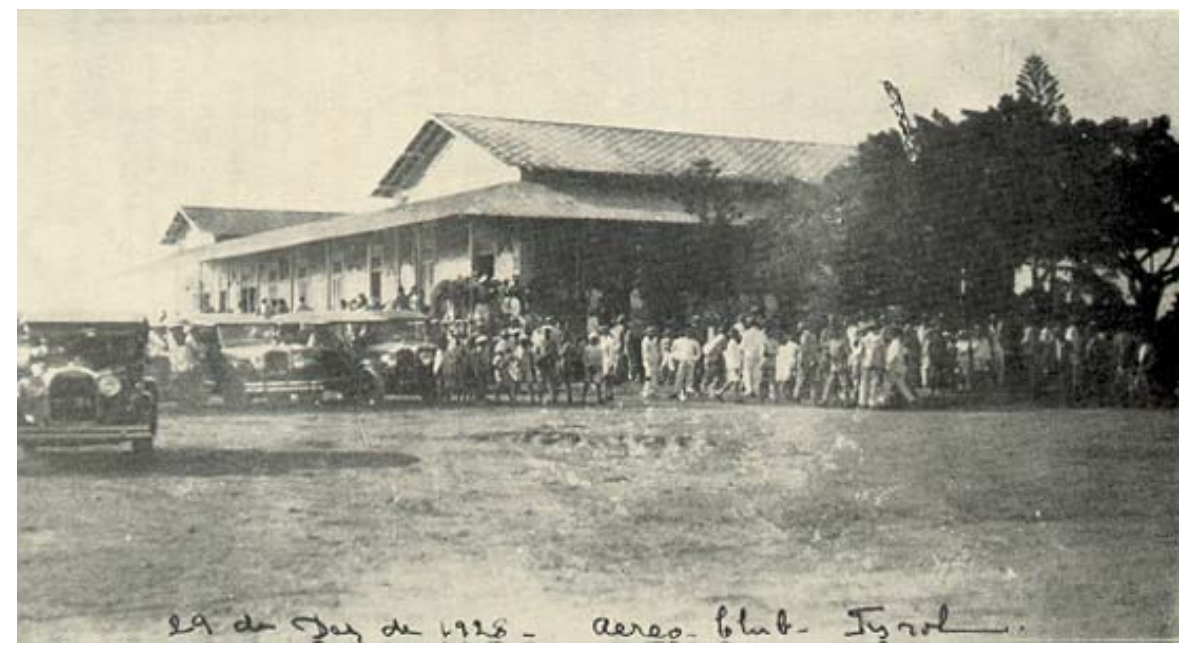

Fig. 5-04: inauguração do Aero-Club de Natal (antiga residência do ex-governador Alberto Maranhão), em 29 de dezembro de 1928. Fonte: Viveiros, 1974. 


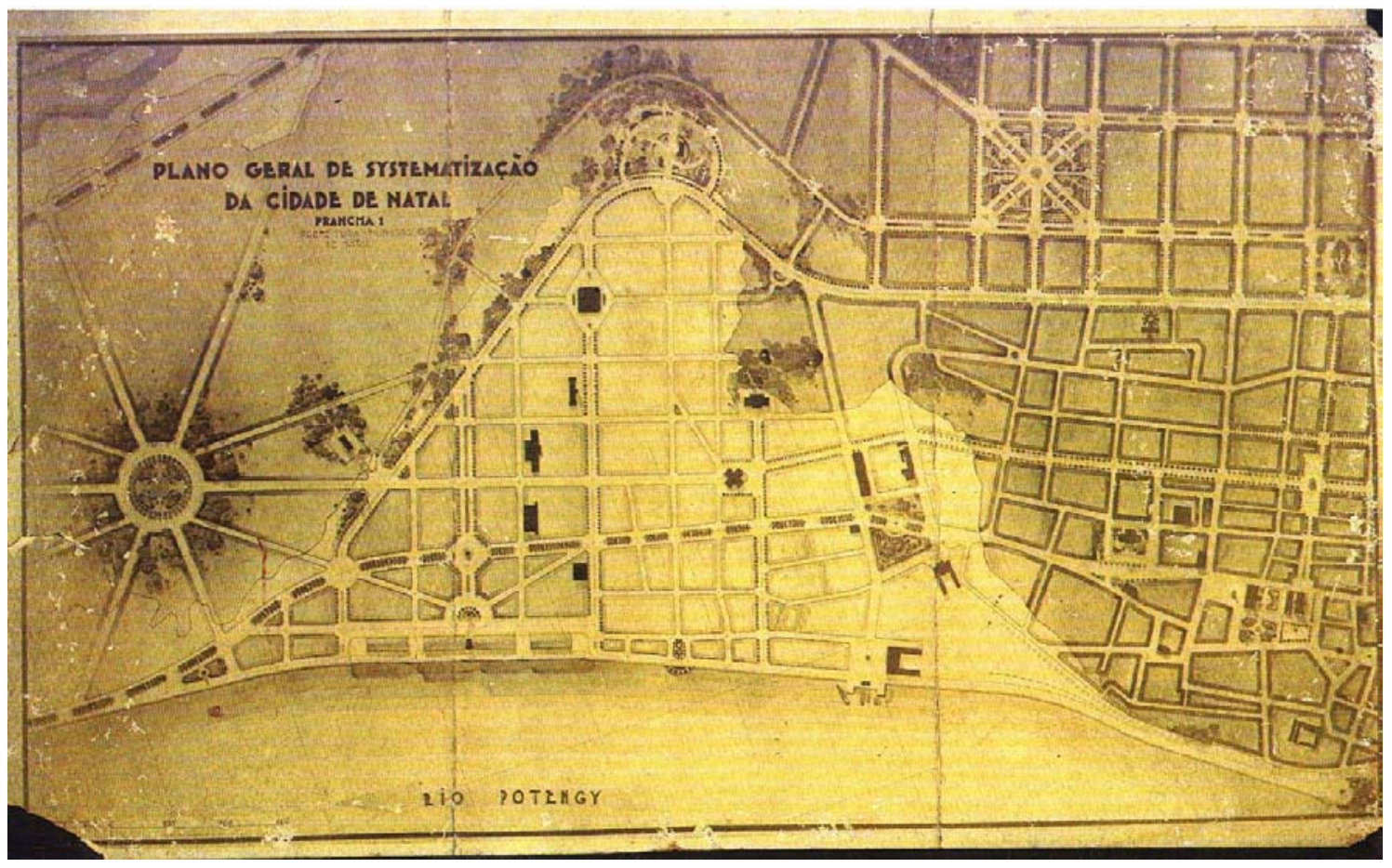

Fig. 5-05: Trecho do Plano Geral de Sistematização Fonte: Acervo Edgard Ramalho Dantas 
... e das tortuosas retificações 
O que significou o processo de transformações por que Natal passou ao longo da década de 1920, pode-se perguntar ao final dos percursos desta pesquisa.

Vários temas podem ser mobilizados para discutir esses possíveis significados, como o da "modernização incompleta", formulada e interpretada por uma elite constituída fora dos meios urbanos, mas que precisava fazê-la na cidade, como oposição ao passado colonial representado pelo mundo rural. A própria vinculação entre a "estética" do período colonial (cidades em desalinho, que não contradizem a natureza, sem rigor, método ou previdência, exprimindo o "desleixo da colonização" portuguesa ${ }^{1}$ ) e o atraso econômico do Brasil está na raiz de muitos discursos que buscavam uma nova estruturação espacial de nossas cidades concernente às necessidades do capitalismo do século XX, mas que não possibilitou a contrapartida de uma modernização social, que implicaria na ruptura com um modo de sociabilidade baseado na esfera privada dos interesses e favores. ${ }^{2}$

Dentro desse processo de transformações das cidades brasileiras, em destaque Natal, pode-se observar - como um segundo tema - que a forma de inserção do urbanismo conformou-se ao projeto de modernização das elites - inclusive porque grande parte dos técnicos, engenheiros, arquitetos e urbanistas faziam parte desta elite -, construindo um espaço, urbano e social, que repôs as formas despóticas do mundo colonial à sua imagem e semelhança; assim, dentro desta "modernidade divorciada do real", o urbanismo contribuiu à despolitização dos conflitos sociais e urbanos, pretendendo-se racional e imune às pressões dos grupos hegemônicos. A crescente influência do urbanismo americano a partir do final da década de 1920, com a ênfase em uma legislação urbana centrada no zoning e nas comissões do plano da cidade, corroborou à tese de que o urbanismo e o planejamento poderiam estar acima das disputas e interesses político-econômicos.

A prática urbanística teve, então, papel fundamental neste projeto de modernização das cidades em, pelo menos, dois aspectos. O processo de introdução do zoning no Brasil pode ajudar-nos a compreender o primeiro deles. Ao afirmar que esse instrumento de controle do uso e ocupação do solo poderia secundar um processo "natural" de crescimento e ordenação da cidade (com a densidade decrescente do centro à periferia, a separação por funções das partes da cidade, etc. ${ }^{3}$ ), conferiu "cientificidade" e "neutralidade" a um modelo de cidade que vinha sendo moldado desde o final do século XIX. O urbanismo ratificou este processo e, ao fazê-lo - isto nos leva ao segundo aspecto -, pode ter deslegitimado e obstruído a possibilidade de constituição de uma esfera pública, porque irrelevava a participação popular e a excluía das instâncias de decisão e gestão.

\footnotetext{
${ }^{1}$ Holanda, 1995, p.110.

2 Telles, 1998.

${ }^{3}$ Cf. Mancuso, 1980.
} 
Embora os anos vinte tenham assistido uma maior mobilização das classes trabalhadoras, populares, para além dos estreitos limites das classes dominantes, e novas possibilidades de acesso e discussão cultural, valorizando elementos que, a priori, estariam de fora da construção da imagem de uma cidade modernizada, europeizada, as contradições deste processo de modernização - que no espaço urbano se encontravam de forma mais latente nos bairros populares, longe do centro e dos bairros "chiques" - não encontravam voz na imprensa oficial. Os únicos problemas que transpareciam nos artigos, com raras exceções, eram de ordem estética e funcional, empecilhos ao correto funcionamento de uma cidade que se pretendia moderna quão modernos eram o carro e o avião.

\section{Nas pistas de um turista aprendiz}

Não nos interessa aqui discutir ainda mais esses temas, já amplamente abordados mas não esgotados - pela historiografia produzida no Brasil sobre a modernização e as representações das cidades, em especial na Primeira República, e a emergência do saber urbanístico na disputa de poder entre os saberes que se debruçaram sobre os "problemas urbanos". Para fechar esta dissertação, propomos acompanhar o relato de um viajante muito peculiar, de interesse polimorfos, e cuja atuação e produção intelectual ajudou a forjar as discussões e os significados de um projeto de modernidade para o Brasil.

Referimo-nos aqui à viagem de Mário de Andrade ao Nordeste como "turista aprendiz", entre dezembro de 1928 e fevereiro de 1929. Na verdade, essa viagem ao Nordeste, desejo acalentado desde o início da sua correspondência com Câmara Cascudo, em 1924, e sob os influxos da redefinição do projeto modernista de "descobrimento do Brasil", tornou-se a segunda parte do livro que conteria inicialmente a viagem a Amazônia, em 1927. ${ }^{4}$ Se a Amazônia apareceria para Mário, no período de redação de "Macunaíma", como a sede de uma vivência tropical, marcada pelo ócio criador, o Nordeste, em especial, também seria considerado como um dos ricos repositórios dos elementos da brasilidade, da tradição e da cultura popular. ${ }^{5}$

\footnotetext{
"Viajando pelo Nordeste, nosso cronista nos comunica que ainda há um Brasil por descobrir e valorizar, para ser entendido [como] vida e cultura do povo. Essa dimensão, a da pesquisa etnográfica e a do enfoque sociológico, revelará as danças dramáticas, o catimbó e procurará analisar as condições de vida da região, numa perspectiva nova que deseja abandonar a caracterização do regional através do exótico e do pitoresco, porque estará preocupada com as relações de produção e com as classes sociais". ${ }^{6}$
}

Nessa condição auto-reconhecida de que não há mais terras a desbravar ou monstros e mentiras a contar a valer, Mário se constitui num narrador singular. Buscando incorporar o Brasil a sua vivência, ${ }^{7}$ revelará uma cidade em uma outra representação, distante daquelas oficiais, das apologias do progresso e da civilização, ou as do saber médico e do saber urbanístico, em ascensão nos anos 1920 em Natal.

Deve-se observar ainda que, além de ser um observador interessado e crítico envolvido na construção, por exemplo, de um "narrador brasileiro desgeograficado", como faria com o anti-herói Macunaíma -, Mário é um observador privilegiado. Os seus interesses em adentrar uma cidade que, muitas vezes, só se conhecia pelos assombros dos textos dos jornais, é facilitado e possibilitado pelos "cicerones" que lhe acompanham ou fazem vistas

\footnotetext{
${ }^{4}$ Lopez, 1976.

${ }^{5}$ Ibid., p.17, 21.

${ }^{6}$ Ibid., p. 41 .

7 Ibid.
} 
grossas às suas andanças e participações em eventos populares que, cada vez mais, eram reprimidas e/ou enquadradas pelas políticas e normativas de uso do espaço público - como o catimbó e o "Boi" do Alecrim. Na Cidade da Parahyba, atual João Pessoa, foi recebido por José Américo de Almeida, Ademar Vidal e Silvino Olavo; em Recife, por, dentre outros, Cícero Dias e Ascenso Ferreira, companheiro de folganças e aventuras carnavelescas; e, em Natal, por Cristovam Dantas (filho de Manoel Dantas), Antonio Bento, Omar O'Grady e, em especial, Luis da Câmara Cascudo.

Antes da estadia mais alentada entre 1928 e 1929, Mário passara algumas horas em Natal, em 1927, quando retornava das viagens primeiras do "turista aprendiz". O breve relato sobre Natal serve-nos para começar a adentrar uma outra cidade que seria desvelada.

\begin{abstract}
"E a entrada linda de Natal pelas doze horas. Manso o Potenji. Forte dos Reis Magos a bombordo. Estamos enfim no Rio Grande do Norte, propriedade do meu amigo Luís da Câmara Cascudo, quem será? São dezenas de barquinhos se aproximando do baependi. Nisto vejo um rapaz gesticulando imensamente, exatíssimo no estilo das do Cascudinho, era ele. E era mesmo. Em terra, apresentações, o simpático prefeito Omar O’Grady, o Secretário Geral de Estado [Cristovam Dantas]. Autos. A praia maravilhos de Areia PReta, Petrópolis, Refoles, Reservatório. Encontro o poeta Jorge Fernandes na casa dele, encorujado. Cerveja no restaurantinho. E o jantar na Escola Doméstica, Butantã de Natal. Sem discurso. Partimos já era bem dentro da noite. Vida de bordo se preparando para dormir". ${ }^{8}$
\end{abstract}

O itinerário de poucas horas construído pelos seus "cicerones", marcado pelo oficialismo da recepção a um visitante já tão ilustre, passeia por algumas das principais realizações da administração O'Grady. Contudo, impressiona-lhe mais o afeto - recíproco da recepção, como revelaria depois em carta a Cascudo, ${ }^{9}$ e a paisagem da Praia de Areia Preta. Das várias fotos que faz da praia, em uma delas faz questão de enquadrar o prefeito Omar O’Grady, com seu indefectível terno branco e chapéu panamá, o "inventor de Areia Preta". 10

A viagem ao Nordeste serviu tanto às pesquisas etnográficas de Mário - tarefa para a qual Cascudo se configurou um importante interlocutor - quanto para o descanso da sua vida atribulada na metrópole paulistana. Contudo, para viabilizá-la - a viagem - Mário comprometeu-se em produzir uma série de artigos para o Diário Nacional. Há portanto uma diferença entre a estrutura e a forma de elaboração das duas narrativas. Embora o ponto de partida seja comum - a forma de um diário de viagem, há uma predominância ou preocupação na primeira parte com a elaboração literária, o que pode ser verificado inclusive nas legendas das fotos; na segunda parte, que abrange a viagem pelo Nordeste, há uma maior aproximação ao discurso jornalístico, "uma leitura mais rápida e artisticamente menos compromissada que teria interesse em obter informações sobre a região visitada pelo cronista" ${ }^{11}$ Essa aproximação iria marcar muitos dos registros de Mário sobre Natal.

O primeiro relato sobre a cidade, pouco após a sua chegada, é um exemplo. Acompanhemos então a narrativa:

\footnotetext{
"Natal era o destino do meu descanso e estou descansando. Gosto de Natal demais. Com os seus 35 mil habitantes, é um encanto de cidadinha clara, moderna, cheia de ruas conhecidas encostadas na sombra de árvores formidáveis. De todas estas capitais do norte é a mais democraticamente capital, honesta, sem curiosidade excepcional nenhuma. Não possui um mercado que nem o Ver-o-peso de Belém, uma praia de boa vista como a do Recife, coisas extraordinárias. Não transportam a
}

\footnotetext{
8 Andrade, M., 1976, p.191, “07 de agosto" de 1927.

${ }^{9}$ Idem, 2000, p.81-82, carta datada de "S. Paulo 29-IX-27".

${ }^{10}$ Ibid, p.315, "Paraíba, 1 e 2 de fevereiro"de 1929.

${ }^{11}$ Lopez, 1976, p.36.
} 
gente pra Colônia que nem as vielas, os becos, as igrejas de Recife, Igaraçu, S. Salvador... Todas estas coisas são encantos, não tem dúvida porém encantos um bocado egoísticos. Coisa para viajante visitar e gostar, originalidades que tornam estas cidades exóticas até mesmo pra brasileiro". ${ }^{12}$

E o cronista do século XX continua na mesma toada. "Natal não é assim não". É uma cidade cotidiana, "tão brasileiramente humana" que, apesar de ser capital, e percebe-se que é uma cidade capital, ainda mantém o seu "conforto praceano", aquele "ar de chacra, [dum] descanso frutecente". "Uma cidade cuja beleza se descobre aos poucos, ao entrar em seu ritmo urbano - bem distinto do ritmo da metrópole de "Paulicéia desvairada".

“... mal a barca traz a gente de bordo pra escadinha do cais, sobre-se a escadinha e se está em plena 'city'. O centro é ali mesmo, Hotel Internacional, restaurantes, barbearias, redações, bancos, casas de comércio, telégrafo. É tudo ali mesmo, na rua que a escadinha abriu no meio do arvoredo, com todos os bondes e ônibus da cidade-passando". ${ }^{14}$

Ao ritmo da City, do bairro comercial da Ribeira, com seu lufa-lufa diário e mais agitado, logo se sucede um outro ritmo, para o qual adverte Mário, a medida que sobe a cidade:

"É bom não andar muito a pé, logo principiam ladeiras preguiçosas, mansas e compridas, as ruas se alargam, avenidas magníficas cheias de ar, nenhuma nota de novo-rico. As casas têm aquela humanidade feliz de certos bairros burgueses de $\mathrm{S}$. Paulo, não chamam a atenção. Os largos são cheios de folhagens. A praça Padre João Maria, com o busto do bom no centro, é uma ventura de quase pátio, um dos melhores encantos de Natal. [...]. Vem o palácio do governo, familiar, aberto, casa excelente. A Prefeitura, um bocado pretenciosa [de arquitetura eclética] se enfeita acolá. Os espaços vão se tornando cada vez mais largos. No bairro alto de Petrópolis a avenida Atlântica se acaba no dó-de-peito dum belveder e mostra lá embaixo, Areia Preta, uma das praias mais encantadoras que eu conheço. E, se o rumo for outro, chegamos ao Tirol, altura onde moro hospedado pela ventania. Eh! ventos, ventos de Natal, me atravessando como se eu fosse um véu. Sou véu. Não atravanco a paisagem, não tenho obrigação de ver coisas exóticas... Estou vivendo a vida de meu país...". ${ }^{15}$

Falar da cidade significava uma oportunidade para fazer a sua profissão de fé antiviajante - como já ironizara no longo subtítulo dos registro do "turista aprendiz", "viagens pelo Amazonas até o Peru, pelo Madeira até a Bolívia e por Marajó até dizer chega". O seu interesse é pela cidade cotidiana, humanamente brasileira, como Natal se afigurava para Mário, onde os elementos singulares do Brasil poderiam ser encontrados. Um pouco mais a frente, Mário tocaria num tema caro à construção narrativa historiográfica sobre Natal - a herança do passado colonial na paisagem urbana da cidade.

"Natal é feito S. Paulo: cidade mocinha, podendo progredir à vontade sem ter coisa que dói destruir. Isso é muito importante para nós. O problema da destruição ou

\footnotetext{
12 Andrade, M., 1976, p.232, "Natal, 16 de dezembro" de 1928.

13 Ibid., p.232-33.

14 Ibid., p.233.

15 Ibid.
} 
conservação da Sé, da Bahia, por exemplo, confesso que por mim não sei resolver". ${ }^{16}$

Sem saber resolver o problema, interessa a Mário marcar que, embora fosse modernista - "Dizem que sou modernista e... paciência!" - as tradições brasileiras nunca lhe desinteressaram. Ao contrário, procurava estudá-las e continuar, a seu modo, dentro delas, afirmava. Contudo, dentro do espírito do projeto modernista que ajudou a construir, recusaria as tradições "imóveis", aquelas cristalizadas para o deleite de parte da elite, a ridicularidade da "carroça do rei da Inglaterra", como diria. Ao invés da forma objetiva, interessava, isto sim, o "espírito, a psicologia". A "tolice básica" da arquitetura "neo-colonial" - aspas colocadas pelo próprio Mário - consistia nisso: "pegaram, a maioria, nas formas decorativas coloniais, reduziram elas a fórmulas, que ajuntaram restacueramente, dentro do espírito de arrivismo, que domina as partes progressistas do país". ${ }^{17}$ Depois continuaria,

\begin{abstract}
“O problema da Sé está mas é anunciado errado. É muito mais grandioso do que a derrubada ou não derrubada dum casarão pra alargamento de rua. O próprio centro urbano da cidade alta é que se tem de resolver se é prático ou não ficar onde está. Todas aquelas ladeiras, quedas de sopetão, torceduras de terrenos são absolutamente contrárias a qualquer norma utilitária de urbanismo contemporâneo. Não é possível aplainar aquilo e retificar as ruas sem arrasar tudo. Ou se destrói tudo para atualizar aquilo, ou, qualquer paliativo destruirá tradições curiosas e mesmo valiosas que nem a dita Sé, não passando de paliativo e não resolvendo nada - esse é o problema". ${ }^{18}$
\end{abstract}

Natal, ao contrário, "não possui problema desse". Se aqui Mário não desconstrói as representações em negativo da cidade do período colonial, ele não lê esses elementos em Natal, onde "o que é velho não é... antigo, pouco ou nenhum valor tem". As suas tradições eram todas móveis, as cantorias, as danças. O seu espaço era moderno, de um "bem-estar de agora", do tênis, da piscina, do bar, dos aeroplanos pintando o sete no ar, das moças bonitas e bem vestidas, dos homens de branco, sem "nenhuma Europa tradicional, te dana!". ${ }^{19}$

A cidade que interessa a Mário, portanto, era a cidade da tradição e da cultura popular. E Natal era, pode-se perceber a partir do relato do turista aprendiz, uma cidade onde as tradições ainda se faziam presentes com vitalidade, apesar dos anos, das décadas, de restrições e repressões; era a cidade do embolador de coco, das melodias e do cancioneiro popular, das sessões de feitiçaria, das procissões fluviais, da religiosidade sincrética, dos Pastoris, das Cheganças, dos Congos e do "Boi" de Reis, matérias que interessavam ao seu registro etnográfico, ao projeto nacionalista dos modernistas, trabalhando a aproximação entre a vanguarda crítica e o processo criativo popular. ${ }^{20}$

Contudo, para chegar a essa cidade, alijada dos espaços centrais e cada vez mais circunscrita, "lá no fundo dum bairro pobre, sem iluminação, sem bonde, branquejado pelo areão das dunas", Mário precisava dos seus "cicerones":

"Hoje o Boi do Alecrim, saiu pra rua e está dançando pros natalenses. Os coitados estão inteiramente às nossas ordens só porque Luis da Câmara Cascudo, e eu de embrulho, conseguimos que pudessem dançar na rua sem pagar a licença da Polícia.

\footnotetext{
16 Ibid, p.254, "Natal, 29 de dezembro [de 1928], 17 horas".

17 Ibid.

${ }^{18} \mathrm{Ibid}$, p. 255

${ }^{19}$ Ibid.

${ }^{20}$ Lopez, 1976, p.16.
} 
Infelizmente é assim, sim. Civilização brasileira consiste em impecilhar as tradições vivas que possuímos de mais nossas". ${ }^{21}$

Das errâncias por essa cidade, dos espaços (ainda) não normatizados, emerge a representação de uma outra Natal, da vida difícil, da alimentação irregular, das casinholas pobres e suas "camarinhas" insalubres, dos "causos" populares, das ruas poerentas, distantes das benesses do processo de modernização.

Distante portanto daquela cidade que Omar O'Grady ajudou a estruturar ao longo dos anos 1920. Prefeito que, lembraria depois o próprio Mário - ao chegar na Cidade da Parahyba e constatar o desmantelo da mistura entre o novo e o velho - foi o "inventor de Areia Preta, de Petrópolis e da ladeira que desce da praça do Palácio do Governo [avenida Junqueira Aires]". Espaços que, depois, se tornariam símbolos do processo de modernização e suas tortuosas retificações por que Natal passou nos anos 1920.

${ }^{21}$ Ibid, p.267, "Natal, 6 de janeiro [de 1929], 22 horas". 


\section{BIBLIOGRAFIA}

ALBUQUERQUE JR., Durval M. de. A invenção do Nordeste e outras artes. 2 ed. Recife: FJN, Massangana; São Paulo: Cortez, 2001.

ALMEIDA, José Américo. (1923) A Paraíba e seus problemas. 4 ed. facsimilar. Brasília: Senado Federal, 1994.

ANDRADE, Mário de. Cartas de Mário de Andrade a Luis da Câmara Cascudo. Belo Horizonte: Itatiaia, 2000. (Obras de Mário de Andrade, vol. 24)

Mário de Andrade: fotógrafo e turista aprendiz. São Paulo: Instituto de Estudos Brasileiros, 1993.

O Turista Aprendiz: São Paulo: Duas Cidades, 1976.

AVELAR JR., Odilardo V. Política de combate a seca no Nordeste: uma ideologia para o planejamento regional. 1994. Tese (Doutorado em História) - FFLCH, USP, São Paulo, 1994.

AZEVEDO, Neroaldo P. de. Modernismo e Regionalismo: os anos 20 em Pernambuco. João Pessoa: Secretaria de Educação e Cultura da Paraíba, 1984.

BELluZZO, Ana Maria de M. O Brasil dos viajantes. 2 ed. 3 vol. São Paulo: Metalivros; Rio de Janeiro: Objetiva, 1999.

BERMAN, Marshall. (1982) Tudo que é sólido desmancha no ar: a aventura da modernidade. trad. C.F. Moisés e A.M.L. Ioratti. São Paulo: Companhia das Letras, 1986.

BOLLE, Willi. A cidade sem nenhum caráter: leitura da Paulicéia Desvairada de Mário de Andrade. Espaço e Debates, São Paulo, ano IX, n.27, p.14-27, 1989.

BRANDÃO, Ambrosio Fernandes [1618?]. Diálogos das grandezas do Brasil (introdução Capistrano de Abreu). Rio de Janeiro: Officina Industrial Gráfica, 1930.

BRESCIANI, Maria Stella M. Forjar a identidade brasileira nos anos 1920-1940. In HARDMAN, Francisco F. (org.) Morte e Progresso: cultura brasileira como apagamento de rastros. São Paulo: Fundação Editora da Unesp, p.27-61, 1998 (a).

BRITO, Francisco Saturnino R. de. (1913) As secas do Norte. In Obras Completas de Saturnino de Brito. vol. XVIII. Memórias diversas: notícias, memórias e artigos vários. Rio de Janeiro: Imprensa Nacional, 1944.

BURKE, Peter. (1990) A Escola dos Annales (1929-1989): a Revolução Francesa da historiografia. trad. N. Odalia. 4 reimp. São Paulo: Fundação Ed. UNESP, 1997.

(org.) A Escrita da História: novas perspectivas. trad. M. Lopes. São Paulo: Ed. UNESP, 1992.

BYINGTON, Silvia I. "No balanço da rede". In: Pentimentos modernistas: as cores do Brasil na correspondência entre Luís da Câmara Cascudo e Mário de Andrade. 2000. Dissertação (Mestrado em História Social da Cultura) - PUC-Rio, Rio de Janeiro, 2000.

CANDIDO, Antonio. (org.) Sergio Buarque de Holanda e o Brasil. São Paulo: Fundação Perseu Abramo, 1998.

(1965) Literatura e cultura de 1900 a 1945 (panorama para estrangeiros). In Literatura e Sociedade. 8 ed. São Paulo: T. A. Queiroz, Publifolha, 2000.

CARVALHO, José M. de. A formação das Almas: o imaginário da República no Brasil. São Paulo: Companhia das Letras, 1990.

Letras, 1999.

(1987) Os bestializados: o Rio de Janeiro e a República que não foi. 3 ed. São Paulo: Companhia das

. A Construção da ordem: a elite política imperial. Brasília: Ed. Universidade de Brasília, 1981.

CARVALHO, Marta M. C. de. Educação e política nos anos 20: a desilusão com a República e o entusiasmo pela educação. In DE LORENZO, H. C. e COSTA, W. P. da. (orgs.) A década de 1920 e as origens do Brasil moderno. São Paulo: Ed. UNESP, p.115-132, 1997.

CUNHA, Euclydes da. (1902) Os Sertões: campanha de Canudos. 39 ed. Rio de Janeiro: Livraria Francisco Alves; Publifolha, 2000.

DE LORENZO, Helena C. e COSTA, Wilma P. da. (orgs.) A década de 1920 e as origens do Brasil moderno. São Paulo: Ed. UNESP, 1997. 
DEÁK, Csaba. Acumulação entravada no Brasil e a crise dos anos 80. In DEÁK, C. e SCHIFFER, S. R. (orgs.) O processo de urbanização no Brasil. São Paulo: Edusp, p.19-48, 1999.

FAUSTO, Boris. (1970) A revolução de 1930: historiografia e história. 8 ed. São Paulo: Brasiliense, 1982.

FOUCAULT, Michel. (1979) Microfísica do Poder. 7 ed. Rio de Janeiro: Graal, 1988.

GORELIK, Adrián. O moderno em debate: cidade, modernidade, modernização. In MIRANDA, Wander M. (org.) Narrativas da modernidade. Belo Horizonte: Autêntica, 1999.

HERSCHMANN, Micael M., PEREIRA, Carlos A. M. O imaginário moderno no Brasil. In Brasil moderno: medicina, educação e engenharia nos anos 20-30. Rio de Janeiro: Rocco, p.9-42, 1994.

HERSCHMANN, Micael M. A arte do operatório: medicina, naturalismo e positivismo - 1900-37. In $A$ invenção do Brasil moderno: medicina, educação e engenharia nos anos 20-30. Rio de Janeiro: Rocco, p.43-65, 1994.

HOLANDA, Sérgio B. de. (1936) Raízes do Brasil. 26 ed. São Paulo: Companhia das Letras, 1995.

KOSTER, Henry. (1817) Viagens ao Nordeste do Brasil. trad. e notas de Câmara Cascudo. São Paulo: Companhia Editora Nacional, 1942.

LAHUERTA, Milton. Os intelectuais e os anos 20: moderno, modernista, modernização. In DE LORENZO, H. C. e COSTA, W. P. (orgs.) A década de 1920 e as origens do Brasil moderno. São Paulo: Ed. UNESP, p.73-92, 1997.

LE GOFF, Jacques. (1997) Por amor às cidades: conversações com Jean Lebrun. trad. R.C.C. Moraes. São Paulo: Fundação Editora da UNESP, 1998.

LOPEZ, Telê A. As viagens e o fotógrafo. In ANDRADE, M. Mário de Andrade: fotógrafo e turista aprendiz. São Paulo: Instituto de Estudos Brasileiros, p.109-119, 1993. (1981) “Uma difícil conjugação”. In Mariodeandradiando. São Paulo: Hucitec, 1995. (1979) “Arlequim e Modernidade”. In Mariodeandradiando. São Paulo: Hucitec, 1995.

"Viagens etnográficas" de Mário de Andrade, Um projeto de livro, A edição de "O Turista Aprendiz" e A bordo do Diário. In ANDRADE, M. O Turista Aprendiz. São Paulo: Duas Cidades, p.15-46, 1976.

MAGALHÃES, Gildo. Força e Luæ: Eletricidade e Modernização na República Velha. São Paulo: Ed. Unesp, Fapesp, 2000.

MARTINS, Luciana de L. O Rio de Janeiro dos viajantes: o olhar britânico (1800-1850). Rio de Janeiro: Jorge Zahar, 2001.

MARX, Karl e ENGELS, Friedrich. (1848) Manifesto do Partido Comunista. In REIS FILHO, Daniel Aarão (org.). O manifesto comunista 150 anos depois. Rio de Janeiro: Contraponto; São Paulo: Fundação Perseu Abramo, 1998.

MELLO, Evaldo Cabral de. Rubro Veio: o imaginário da restauração pernambucana. Rio de Janeiro: Nova Fronteira, 1986.

O Nordeste agrário e o Império. Rio de Janeiro: Nova Fronteira; Brasília: INL, 1984.

MORAES, João Q. de. O positivismo nos anos 20: entre a ordem e o progresso. In DE LORENZO, H. C. e COSTA, W. P. (orgs.) A década de 1920 e as origens do Brasil moderno. São Paulo: Ed. UNESP, p.73-92, 1997.

MORI, Karla K. A ideologia na constituição do espaço brasileiro. In DEÁK, C. e SCHIFFER, S. R. (orgs.) O processo de urbanização no Brasil. São Paulo: Edusp, p.49-71, 1999.

NEVES, Francisco C. A “capital de um pavoroso reino": Fortaleza e a seca de 1877. Tempo, Rio de Janeiro, vol.5, n.9, p.93-111, jul. 2000.

Curral dos Bárbaros: os Campos de Concentração no Ceará (1915 e 1932). Revista Brasileira de História, São Paulo, vol.15, n.29, p.93-122, 1995.

NEVES, Margarida da S. O Sertão (en)cantado: cores e sonoridades. In: site Modernos Descobrimentos do Brasil, disponível em: venus.rdc.puc-rio.br/gorg/desc/cascudo/frame.htm. Acesso em 16 jun. 2002.

ODALIA, Nilo. As formas do mesmo: ensaios sobre o pensamento historiográfico de Varnhagen e Oliveira Viana. São Paulo: Fundação Editora da UNESP, 1997.

OLIVEIRA, Francisco de. A metamorfose da arribaçã. In hegemonia imperfeita. Petrópolis: Vozes, p.79-120, 1998.

Os direitos do Antivalor: a economia política da

PAULINO, Ana M. Fotografia: uma arte para Mário. In ANDRADE, M. Mário de Andrade: fotógrafo e turista aprendiz. São Paulo: Instituto de Estudos Brasileiros, p124.121-1993. 
PERISSINOTO, Renato M. Classes dominantes, Estado e os conflitos políticos na Primeira República em São Paulo: sugestões para pensar a década de 1920. In DE LORENZO, H. C. e COSTA, W. P. (orgs.) $A$ década de 1920 e as origens do Brasil moderno. São Paulo: Ed. UNESP, p.37-69, 1997.

ROSEN, George. Da Polícia Médica à Medicina Social: ensaios sobre a história da assistência médica. trad. A. L. Souza. Rio de Janeiro: Graal, 1980.

ROUANET, Sergio P. Prefácio. In VELOSO, M. e MADEIRA, A. Leituras brasileiras: itinerários no pensamento social e na literatura. São Paulo: Paz e Terra, 1999.

SANDES, Noé F. A invenção da Nação: entre a Monarquia e a República. 1997. Tese (Doutorado em História) FFLCH-HI, USP, São Paulo, 1997.

SANTOS, Sydney M. G. André Rebouças e seu tempo. Rio de Janeiro, s.n., 1985.

SCHWARCZ, Lilia M. O espetáculo das raças: cientistas, instituições e questão racial no Brasil - 1870-1930. São Paulo: Companhia das Letras, 1993.

SEVCENKO, Nicolau. Orfeu extático na metrópole: São Paulo, sociedade e cultura nos frementes anos 20. São Paulo: Companhia das Letras, 1992.

Fragmentação, simultaneidade, sincronização: o tempo, o espaço e a megalópole moderna. Espaço e Debates, São Paulo, n. 34, ano XI, p. 18-22, 1991.

(1983) Literatura como Missão: tensões sociais e criação cultural na Primeira República. 4 ed. São Paulo:Brasiliense, 1999.

SILVA, Janice T. Raízes da ideologia do planejamento: Nordeste (1889-1930). São Paulo: Livraria Editora Ciências Humanas Ltda., 1978.

SPIX e MARTIUS. Viagem pelo Brasil. 2 vol. trad. L. F. Lahneyer. Rio de Janeiro, 1938.

TELLES, Vera da S. Direitos sociais: afinal do que se trata?. Belo Horizonte: Ed.UFMG, 1999.

VELOSO, Mariza e MADEIRA, Angélica. Leituras brasileiras: itinerários no pensamento social e na literatura. São Paulo: Paz e Terra, 1999.

VENTURA, Roberto. Estilo tropical: história cultural e polêmicas literárias no Brasil. São Paulo: Companhia das Letras, 1991.

Guia de leitura - Euclydes da Cunha e Os Sertões. In CUNHA, E. da. Os Sertões: campanha de Canudos. 39 ed. Rio de Janeiro: Livraria Francisco Alves; Publifolha, 2000

\section{Sobre história do urbanismo}

AALEN, Frederick H. A. English Origins. In WARD, S. V. The Garden City: past, present and future. Londres: E \& FN Spon, 1992.

BEEVERS, Robert. The Garden City Utopia: a critical biography of Ebenezer Howard. New York: San Martin's Press, 1988.

BEGUIN, François. (1977) As maquinarias inglesas do conforto. Espaço e Debates, São Paulo, n.34, p.39-54, 1991.

BENOIT-LÉVY, Georges. Les Cités-jardins de Letchworth et de Welwin. Le Génie Civil, tome LXXXIII, n. 19, n. 2152 , nov. 1923.

CALABI, Donatella. Storia dell'urbanistica europea. Torino: Paravia Scriptorium, 2000.

CHOAY, Françoise. Destinos da cidade européia: séculos XIX e XX. RUA-Revista de Urbanismo e Arquitetura, Salvador, v. 1, n. 6, p. 08-21, jul.-dez. 1996.

. (1980) A Regra e o Modelo. São Paulo: Perspectiva, 1985.

(1965) O Urbanismo: utopias e realidades. uma antologia. 5 ed. São Paulo: Perspectiva, 1998.

COLLINS, George R. e COLLINS, Christiane C. (1965) Camillo Sitte y el nacimiento del urbanismo moderno. In SITTE, C. Construcción de ciudades segun principios artisticos. Barcelona: Gustavo Gili, 1980.

DAL CO, Francesco. De los parques a la región. Ideología progresista y reforma de la ciudad americana. In CIUCCI, G. et alii. La Ciudad Americana: de la guerra civil al New Deal. Barcelona: Gustavo Gili, p.139-293, 1975. 
FEHL, Gerhard. The Nazi Garden City. In WARD, S. V. The Garden City: past, present and future. Londres: E \& FN Spon, 1992.

GARIN, Eugene. La ciudad ideal. In Ciencia e vida civil en el Renacimiento italiano. Madrid: Taurus, p.49-70, 1982.

GAUDIN, Jean P. The French Garden City. In WARD, S. V. The Garden City: past, present and future. Londres: E \& FN Spon, 1992.

HALL, Peter. Cidades do amanhã. trad. P. Carvalho. São Paulo: Perspectiva, 1995.

HOWARD, Ebenezer. (1898) Garden Cities of To-morrow. 3 ed. London, Faber \& Faber, 1949. (1898) Cidades-Jardins de Amanhã. São Paulo: Hucitec, 1996.

KATZ, Peter. (Ed.) The New Urbanism: toward an Architecture of Community. New York, McGraw-Hill, 1994.

MANCUSO, Franco. (1978) Las experiencias del Zoning. Barcelona: Gustavo Gili, 1980.

MANIERI-ELIA, Mario. Por una ciudad “imperial”: Daniel H. Burnham y el movimiento City Beautiful. In CIUCCI, G. et alii. La Ciudad Americana: de la guerra civil al New Deal. Barcelona: Gustavo Gili, p.01-137, 1975.

MELOSI, Martin V. The Sanitary City: urban infrastructure in America from colonial times to the present. Baltimore: The Johns Hopkins University Press, 2000.

MORA, Alfonso Álvarez. Problemas de investigación en "História urbanística". História Urbana, Valência, n. 1, p. 83-102, 1992.

MORRIS, A. E. J. (1979) Historia de la forma urbana: desde sus orígenes hasta la Revolución Industrial. trad. R. Bernet. 6 ed. Barcelona: Gustavo Gili, 1998.

MUMFORD, Lewis. (1961) A cidade na História: suas origens, transformações e perspectivas. 4 ed. trad. N. R. Silva. São Paulo: Martins Fontes, 1998.

The Garden City idea and Modern Planning (1945). In HOWARD, E. Garden Cities of To-morrow. 3 ed. London, Faber \& Faber, 1949.

OSBORN, F. J. Preface (1945). In HOWARD, E. Garden Cities of To-morrow. 3 ed. London, Faber \& Faber, 1949.

PIÑÓN, Juan Luis. Reflexiones sobre la comparación y la generalización en Historia Urbana. História Urbana, Valência, n. 2, p. 5-20, 1993.

RAMÓN J., Gabriel. Com a pátria nas paredes. A regularização da nomenclatura urbana de Lima (1861). In BRESCIANI, M. S. M. (Org.) Palavras da cidade. Porto Alegre: Ed. Universitária, UFRGS, p.121-136, 2001.

TAFURI, Manfredo. Projecto e utopia: Arquitetura e desenvolvimento no capitalismo. Trad. Conceição Jardim e Eduardo Nogueira. Lisboa: Presença, 1985.

(1980) Introdución: El proyecto histórico. In La Esfera e el Laberinto: Vanguardias e arquitectura de Piranesi a los años setenta. Barcelona: Gustavo Gili, p. 05-28, 1984.

La montaña desencantada. El rascacielos e la Ciudad. In CIUCCI, G. et alii. La Ciudad Americana: de la guerra civil al New Deal. Barcelona: Gustavo Gili, p.387-512, 1975.

TEAFORD, Jon C. (1986) The Twentieth-Century American City. 2 ed. Baltimore: The Johns Hopkins University Press, 1993.

URTEAGA, Luis. Miseria, miasmas y microbios. Las topografias medicas y el estudio del medio ambiente en el siglo XIX. Revista GeoCritica, Barcelona, n.29, set. 1980.

WARD, Stephen V. Introduction. In 1992. The Garden City: past, present and future. Londres: E \& FN Spon,

Sobre história urbana e urbanistica no Brasil

ANDRADE, Carlos R. M. Barry Parker: um arquiteto inglês na cidade de São Paulo. 1998. Tese (Doutorado em Arquitetura e Urbanismo, Estruturas Ambientais) - FAUUSP, São Paulo, 1998.

Camillo Sitte, Camille Martin e Saturnino de Brito: traduções e transferências de idéias urbanísticas. In RIBEIRO, L. C. Q. e PECHMAN, R. Cidade, povo e nação. Gênese do urbanismo moderno. Rio de Janeiro: Civilização Brasileira, p.287-310, 1996.

Dar forma ao informe: o urbanismo e a crise da cidade moderna. In GONÇALVES, M. F. O novo Brasil urbano: impasses, dilemas, perspectivas. Porto Alegre: Mercado Aberto, p.337-348, 1995. 
A Peste e o Plano: o urbanismo sanitarista do eng. Saturnino de Brito. 1992. 2 vol. Dissertação. (Mestrado em Estruturas Ambientais) - FAUUSP, São Paulo, 1992.

ABREU, Maurício de. Pensando a cidade no Brasil do passado. In. SILVA, José B. da et alli. A cidade e o urbano. Fortaleza: EUFC, p.27-52, 1997.

ARANTES, Otília B. F. Urbanismo em fim de linha e outros estudos sobre o colapso da modernização econômica. São Paulo: EDUSP, 1998.

BERTUCCI, Liane M. As transformações urbanas na imprensa operária: São Paulo, na virada do século XX. In Cidade, povo e nação: Gênese do urbanismo moderno. Rio de Janeiro: Civilização Brasileira, p.81-94, 1996.

BONDUKI, Nabil G. Origens da habitação social no Brasil. Arquitetura moderna, Lei do Inquilinato e difusão da casa própria. 2 ed. São Paulo: Estação Liberdade, 1998.

BRESCIANI, Maria S. M. (Org.) Palavras da cidade. Porto Alegre: Ed. Universitária, UFRGS, 2001.

Melhoramentos entre intervenções e projetos estéticos. São Paulo 1850-1950. In Palavras da cidade. Porto Alegre: Ed. Universitária, UFRGS, p.343-366, 2001.

História e historiografia das cidades, um percurso. In FREITAS, M. C. (org.) Historiografia brasileira em perspectiva. São Paulo: Contexto; Universidade São Francisco, p. 237-258, 1998 (b).

As sete portas da cidade. Espaço e Debates, São Paulo, n.34, ano XI, 1991.

BRUAND, Yves. (1981) Arquitetura contemporânea no Brasil. 3 ed. São Paulo: Perspectiva, 1997.

CAMPOS, Candido M. Os rumos da cidade: urbanismo e modernização em São Paulo. São Paulo: Ed. SENAC São Paulo, 2002.

Urbanismo e anti-urbanismo no debate nacional brasileiro, 1900-1945. In SEMINÁRIO DE HISTÓRIA DA CIDADE E DO URBANISMO, 6, out. 2000, Natal-RN. [Anais eletrônicos...] Natal: PPGAU/UFRN, 2000. 1 CD-ROM.

.DEL BRENNA, Giovanna R. (org.) O Rio de Janeiro de "Pereira Passos": uma cidade em questão II. Rio de Janeiro: Index, 1985.

DELSON, Roberta M. (1979) Novas vilas para o Brasil-colônia: planejamento espacial e social no século XVIII. Brasília: Alva-Ciord, 1997.

FELDMAN, Sarah. Os anos 30 e a difusão do urbanismo americano no Brasil. In SEMINÁRIO DE HISTÓRIA DA CIDADE E DO URBANISMO, 6, out. 2000, Natal-RN. [Anais eletrônicos...] Natal: PPGAU, UFRN, 2000. 1 CD-ROM.

FERNANDES, Ana e GOMES, Marco A. A. F. A pesquisa recente em história urbana no Brasil: percursos e questões. In PADILHA, N. (org.) Cidade e Urbanismo: história, teorias e práticas. Salvador: Mestrado em Arquitetura e Urbanismo, FAUUFBA, p.13-28, 1998.

Idealizações urbanas e a construção da Salvador moderna: 1850-1920. Espaço e Debates, São Paulo, ano XI, n.34, p.92-103, 1991.

GOODWIN JR., James W. Visões da cidade na imprensa mineira: Diamantina e Juiz de Fora no fim-de-século. In SEMINÁRIO DE HISTÓRIA DA CIDADE E DO URBANISMO, 6, out. 2000, Natal-RN. [Anais eletrônicos...] Natal: PPGAU, UFRN, 2000. 1 CD-ROM.

GUIMARÃES, Berenice M. A concepção e o projeto de Belo Horizonte: A utopia de Aarão Reis. In RIBEIRO, L. C. Q. e PECHMAN, R. (orgs.) Cidade, Povo e Nação: gênese do urbanismo moderno. Rio de Janeiro: Civilização Brasileira, p.123-140, 1996.

GUNN, Philip. Entre os miasmas e o tanque nos diálogos entre a medicina e a saúde pública sobre a cidade no Brasil. In SEMINÁRIO DE HISTÓRIA DA CIDADE E DO URBANISMO, 5, Campinas, out. 1998, [Anais eletrônicos...]. Campinas: FAU/PUCCAMP, cód. 3.7.5, 1998. 1 CD-ROM.

e CORREIA, Telma de B. O urbanismo: a medicina e a biologia nas palavras e imagens da cidade. In BRESCIANI, M. S. M. (Org.) Palavras da cidade. Porto Alegre: Ed. Universitária, UFRGS, p.227-260, 2001.

LEME, Maria C. da S. Urbanismo: a formação de um conhecimento e de uma atuação profissional. In BRESCIANI, M. S. M. (Org.) Palavras da cidade. Porto Alegre: Ed. Universitária, UFRGS, p.77-93, 2001.

(coord.) Urbanismo no Brasil-1895-1965. São Paulo: Studio Nobel; FAUUSP; FUPAM, 1999.

A formação do urbanismo como disciplina e profissão: São Paulo na primeira metade do século XX. In: RIBEIRO, Luiz César de Queiroz; PECHMAN, Robert (orgs). Cidade, povo e nação: Gênese do urbanismo moderno. Rio de Janeiro: Civilização Brasileira, p. 245-258, 1996. 
LIRA, José T. C. de. O Urbanismo e o seu outro: raça, cultura e cidade no Brasil (1920-1945). Revista Brasileira de Estudos Urbanos e Regionais, São Paulo, n.01, p.47-78, maio de 1999.

Mocambo e Cidade: Regionalismo na Arquitetura e Ordenação do Espaço Habitado. 1996. Tese (Doutorado em Arquitetura e Urbanismo, Estruturas Ambientais) - FAUUSP, São Paulo, 1996.

MARX, Murillo. Cidade no Brasil terra de quem? São Paulo: Edusp, Nobel, 1991.

Nosso chão: do sagrado ao profano. São Paulo: Edusp, 1988.

MENDONÇA, Eneida M. S. Planos para Vitória (ES) segundo Henrique de Novaes. In ENCONTRO NACIONAL DA ANPUR, 8, Porto Alegre, maio 1999, [Anais eletrônicos...] Porto Alegre: PROPUR-UFRGS, 1999.

MOREIRA, Fernando D. A construção de uma cidade moderna: Recife (1909 - 1926). 1994. Dissertação. (Mestrado em Desenvolvimento Urbano) - MDU, UFPE, Recife, 1994.

NOBRE, Ana L. Carmem Portinho: o moderno em construção. Rio de Janeiro: Relume Dumará, Prefeitura, 1999. (Perfis do Rio, v. 25)

PECHMAN, Robert M. Cidades estreitamente vigiadas: o detetive e o urbanista. Rio de Janeiro: Casa da Palavra, 2002.

Cenas primordiais - em como o discurso inventou a cidade. In SEMINÁRIO DE HISTÓRIA DA CIDADE E DO URBANISMO, 5, Campinas, out. 1998, [Anais eletrônicos...] Campinas: FAU/PUCCAMP, cód. 3.6.1, 1998.

PINHEIRO, Eloisa P. Europa, França e Babia: difusão e adaptação de modelos urbanos (Paris, Rio e Salvador). Salvador: EDUFBA, 2002.

A "Haussmannização" e sua difusão como modelo urbano no Brasil. In SEMINÁRIO DE HISTÓRIA DA CIDADE E DO URBANISMO, 5, Campinas, out. 1998, [Anais eletrônicos...] Campinas: FAU/PUCCAMP, cód. 3.5.3, 1998.

PORTINHO, Carmem. Por toda a minha vida: depoimento a Geraldo Edson de Andrade. Rio de Janeiro: Eduerj, 1999.

REZENDE, Vera. Planejamento urbano e ideologia: quatro planos para a cidade do Rio de Janeiro. Rio de Janeiro: Civilização Brasileira, 1982.

REIS FILHO, Nestor Goulart. Imagens de vilas e cidades do Brasil colonial. São Paulo: FUPAM, 2000. (CD-ROM)

Contribuição ao estudo da Evolução Urbana do Brasil 1500/1720. 2 ed. rev. ampl. São Paulo: Pini, 2000.

(b)

Cultura e estratégias de desenvolvimento. In DE LORENZO, Helena C. e COSTA, Wilma P. da. (orgs.) A década de 1920 e as origens do Brasil moderno. São Paulo: Ed. UNESP, P. 143-157, 1997.

Quadro da arquitetura no Brasil. 7 ed. São Paulo: Perspectiva, 1995.

. A Perspectiva do Arquiteto sobre a Cidade. In: PECHMAN, Robert Moses (org.). Olhares sobre a cidade. Rio de Janeiro: Ed. UFRJ, 1994. p. 170-180.

17, 1991.

Sobre a história da urbanização - história urbana. Espaço e Debates, São Paulo, n. 34, ano XI, p. 15-

RIBEIRO, Luiz C. de Q. e PECHMAN, Robert (orgs.) Cidade, Povo e Nação: gênese do urbanismo moderno. Rio de Janeiro: Civilização Brasileira, 1996.

RIBEIRO, Luiz C de Q. e CARDOSO, Adauto L. Da cidade à nação: gênese e evolução do urbanismo no Brasil. In Cidade, Povo e Nação: gênese do urbanismo moderno. Rio de Janeiro: Civilização Brasileira, p.53-78, 1996.

ROLNIK, Raquel. (1997) A cidade e a Lei: Legislação, política urbana e territórios na cidade de São Paulo. 2 ed. São Paulo: Studio Nobel, FAPESP, 1999.

História Urbana: História na cidade? In: FERNANDEZ, Ana e GOMES, Marco Aurélio A. de Filgueiras. (org.). Cidade e História: modernização das cidades brasileiras nos séculos XIX e XX. Salvador: UFBA, FAU/MAU, ANPUR, p. 27-29, 1992.

SEGAWA, Hugo. (1998) Arquiteturas no Brasil 1900-1990. 2 ed. São Paulo: Edusp, 1999.

(1979) Prelúdio da Metrópole: arquitetura e urbanismo em São Paulo na passagem do século XIX ao XX. São Paulo: Ateliê Editorial, 2000. 
SIMÕES JR., José G. O setor de obras públicas e as origens do urbanismo na cidade de São Paulo. Espaço e Debates, São Paulo, n. 34, ano XI, p. 71-74, 1991.

SOMEKH, Nadia. A cidade vertical e o urbanismo modernizador. São Paulo: EDUSP; Estúdio Nobel; FAPESP, 1997.

TOLEDO, Benedito L. Prestes Maia e as origens do Urbanismo Moderno em São Paulo. São Paulo: Empresa das Artes, 1996.

VILLAÇA, Flávio. Uma contribuição para a história do planejamento urbano no Brasil. In DEÁK, Csaba e SCHIFFER, Sueli R. (orgs.) O processo de urbanização no Brasil. São Paulo: Edusp, 1999.

\section{Sobre Natal}

ALECRIM, Octacílio. Provincia Submersa. Rio de Janeiro: Country Club, 1957.

ANDRADE, Maristela O. Anotações sobre a obra etnográfica de Câmara Cascudo. Natal: IHGRN; Salvador: Fundação João Fernandes da Cunha, 1999.

ARAÚJO, Humberto H. Introdução. In GUIMARÃES, João A. (1952) Natal do meu tempo: crônica da cidade do Natal. 2 ed. Natal: SCB, FHG, 1999. Asas de Sófia: Ensaios Cascudianos. Natal: FIERN, SESI, 1998.

. O lirismo nos quintais pobres: a poesia de Jorge Fernandes. Natal: Fundação José Augusto, 1997. Modernismo: anos 20 no Rio Grande do Norte. Natal: Universitária, 1995.

ARAÚJO, Iaperí. (1985) Januário Cicco: um homem além do seu tempo. 2 ed. fac-similar. Natal: Edufrn, 2000.

ARAUjO, Joze S. A. Pizarro e. Memorias historicas do Rio de Janeiro e das provincias annexas á jurisdição do vice-rei do estado do Brasil, dedicadas á El-Rei o senhor D. João VI. Tomo VIII. Rio de Janeiro: Typ. de Silva Porto, 1822.

ARAÚjO, Marta M. de. José Augusto Bezerra de Medeiros: político e educador militante. Natal: Edufrn, Assembléia Legislativa do RN, Fundação José Augusto, 1998.

BARROS, Domingos. Aspectos Norte-Riograndenses: dados e informações. Rio de Janeiro: Typ. do Jornal do Commercio, 1908.

BRITO FILHO, Francisco S. O Problema do destino dos esgotos em Natal. Revista Municipal de Engenharia, Rio de Janeiro, p.73-88, jan. 1938

BUENO, Almir de C. Visões de República: idéias e práticas políticas no Rio Grande do Norte (1880-1895). Natal: Edufrn, 2002.

CARDOSO, Rejane. Eloy Castriciano de Souza: cronologia. In SOUZA, Eloy de. Costumes locais. Natal: Sebo Vermelho, p.47-60, 1999.

CASCUDO, Luis da Câmara. (1968) O tempo e Eu: confidências e proposições. Natal: Edufrn, 1998.

. Vida de Pedro Velho. Natal: Departamento de Imprensa, 1956.

(1952) Apresentação. In GUIMARÃES, João A. (1952) Natal do meu tempo: crônica da cidade do Natal. 2 ed. Natal: Scriptorium Candinha Bezerra, Fundação Hélio Galvão, 1999.

(1947) História da Cidade do Natal. 3 ed. Natal: IHGRN, 1999.

Editora Nacional, 1942

Prefácio do tradutor. In KOSTER, Henry. Viagens ao Nordeste do Brasil. São Paulo: Companhia (1939) Vaqueiros e cantadores: folclore poético do sertão do Ceará, Paraíba, Rio Grande do Norte e Pernambuco. Rio de Janeiro: Ediouro, 2000.

. Cidade do Natal do Rio Grande. Revista de Antropofagia, São Paulo, ano I, n.4, p.03, ago. 1928.

. (1927) Depoimento sobre o "Livro de Poemas" de Jorge Fernandes. In FERNANDES, J. Livro de Poemas. 2 ed. fac-similar. Natal: Fundacao José Augusto, 1997.

- (1926) Cidade do Natal. Natal: Sebo Vermelho, 1999.

Histórias que o tempo leva... (da história do Rio Grande do Norte). São Paulo: Monteiro Lobato \& Co., 1924 (re-edição fac-similar da coleção Mossoroense, série C, vol.757, 1991).

(1921) Alma Patrícia: crítica literária. 2 ed. Natal: Fundação José Augusto, 1998. 
CASTRICIANO, Henrique. (1925) Uma figura literaria do Nordeste: Nísia Floresta. In FREYRE, Gilberto et al. Livro do Nordeste (comemorativo do primeiro centenário do Diário de Pernambuco). 2 ed. fac-similar. Recife: Arquivo Público Estadual, p.138-139, 1979.

(1907) Lourival e seu tempo. A República, Natal, 3, 4, 5, 9, 16, 20 e 24 de julho e 01 de agosto de 1907. In CASCUDO, L. C. Nosso amigo Castriciano. 1874-1947. reminiscências e notas. Recife: Imprensa Universitária, p.189-216, 1965.

(1904) Relatório da Secretaria de Governo. In TAVARES DE LYRA, Augusto. Mensagem lida perante o Congresso Legislativo do Estado do RN a 14 de julho de 1904. Natal: Typ. d'A República, 1905.

CICCO, Januario. Como se hygienizaria Natal: algumas considerações sobre o seu saneamento. Natal: Atelier Typ. M. Victorino, 1920.

CLEMENTINO, Maria do Livramento M. O maquinista do algodão e o capital comercial. Natal: Ed. Universitária, 1986.

COMISSÃO DE SANEAMENTO DE NATAL. Relatório de Abril de 1924 (assinado pelo eng. Henrique de Novaes), datilog., Natal, 1924. (capa, folha de rosto mais 14 fls. numeradas, 6 fotografias em 5 págs., 3 pranchas de desenhos, 6 fls. de tabelas, 7 fls.. com cópias de telegramas e 1 folha solta)

COSTA, Madsleine L. da. Natal, quando a Modernidade vinha de Bonde. O bonde e seu papel dentro do crescimento físico de Natal. Natal: UFRN, 1998. (Monografia, Graduação em Arquitetura e Urbanismo)

DANTAS, George A. F. Natal, “Caes da Europa”: O Plano Geral de Sistematização no contexto de modernização da Cidade, 1929-1930. Natal, UFRN, 1998. (Monografia, Graduação em Arquitetura e Urbanismo)

DANTAS, George A. F. e LIRA, José T. C. Contrastes e encontros: história, cultura e cidade no Nordeste (Natal e Recife, 1928-29). In ENCONTRO NACIONAL DA ANPUR, 9, Rio de Janeiro, maio-jun. 2001, Anais do IX Encontro Nacional da ANPUR, vol. II, p.636-650, 2001.

DANTAS, Manoel (1909) Natal daqui a cinqüenta anos. Natal: Fundação José Augusto, 1996.

Denominação dos municípios (Rio Grande do Norte). Natal: Empreza Typographica Natalense Ltd., 1922 (re-edição fac-similar da coleção Mossoroense, série B, vol.607, 1989).

Homens de Outr'ora. Rio de Janeiro: Pongetti, 1941.

EDUARDO, Anna Rachel B. Do Higienismo ao Saneamento: as modificações do espaço físico de Natal, 1850-1930. 2000. Monografia (Graduação em Arquitetura e Urbanismo) - Curso de Arquitetura e Urbanismo, UFRN, 2000.

ESCRITÓRIO SATURNINO DE BRITO. Saneamento de Natal - relatório - ano de 1935. Rio de Janeiro: s.n.., 1935.

FEITOSA, Polycarpo [Antonio José de Mello e Souza] (1930). Giz̨inha. Natal: Fundação José Augusto, 1965.

FERNANDES, Jorge. (1927) Livro de Poemas. 2 ed. fac-similar. Natal: Fundação José Augusto, 1997.

FERNANDES, Luiz. (1908) A imprensa periódica no Rio Grande do Norte: de 1832 a 1908. 2 ed. Natal: Sebo Vermelho, 1998.

FERREIRA, Angela L. A. De la producción del espacio urbano a la creación de territorios en la ciudad: un estudio sobre la constitución de lo urbano en Natal, Brasil. Barcelona: Universidad de Barcelona, 1996 (tese, doutorado em Geografia Humana)

FERrEIRA, Angela L. A., EDUARDO, Anna R. B., DANTAS, Ana C. C. L., DANTAS, George A. F. Uma cidade sã e bela: a trajetória do saneamento em Natal. 1850-1969. Natal: CAERN, 2003. (aguarda publicação)

GALVÃO, Hélio. (1979) História da fortalez̧a da barra do Rio Grande. 2 ed. Natal: Fundação Hélio Galvão; Scriptorium Candinha Bezerra, 1999.

GUIMARÃES, João A. (1952) Natal do meu tempo: crônica da cidade do Natal. 2 ed. Natal: Sriptorium Candinha Bezerra, Fundação Hélio Galvão, 1999.

LAMARTINE, Juvenal. Meu Governo. Rio de Janeiro, s.n., 1933. (1963) Velhos costumes do meu Sertão. 2 ed. Natal: Fundação José Augusto, 1996.

LIMA, Diógenes C. Câmara Cascudo: um brasileiro feliz. 3 ed. rev. aum. Rio de Janeiro: Lidador, 1998.

LYRA, Carlos. Natal através do tempo. Natal: Sebo Vermelho, 2001.

MAMEDE, Zila. Luís da Câmara Cascudo: 50 anos de vida intelectual. 1918-1968. Bibliografia anotada. 3 vols. Natal: Fundação José Augusto, 1970. 
MELO, Protásio P. de. Contribuição norte-americana à vida natalense. Brasília, s.n., 1993.

MELO, Veríssimo de. Xarias e Canguleiros: ensaios de Folclore e Antropologia Social Aplicada. Natal: Imprensa Universitária, 1968. Contribuição do Nordeste ao Movimento Modernista. Natal: Fundação José Augusto, 1971.

MIRANDA, João M. F. de. Evolução urbana de Natal em 400 anos, 1599-1999. Natal: Prefeitura Municipal de Natal, Governo do RN, 1999. 380 anos de história foto-gráfica de Natal, 1599-1979. Natal, UFRN: Universitária, 1981.

NOVAES, Henrique de. Reminiscências do Rio Grande do Norte. Mossoró, s.ed., 1987. (col. Mossoroense, série C, vol.343)

OLIVEIRA, Giovana P. de. De cidade a Cidade: o processo de modernização de Natal 1889/1913. Natal: Edufrn, 1999.

PINTO, Lauro. Natal que en vi. Natal: Imprensa Universitária, 1971.

PINTO, Lenine. (1976) Os americanos em Natal. 2 ed. Natal: Sebo Vermelho, 2000.

POMBO, Rocha. História do Rio Grande do Norte. Edição comemorativa do centenário da independência do Brasil (1822-1922). Rio de janeiro: Annuario do Brasil; Porto: Renascença portuguesa, 1922.

SANTOS, Pedro A. de L. Natal século XX: do urbanismo ao planejamento urbano. 1998. Tese (Doutorado em Arquitetura e Urbanismo, Estruturas Ambientais) - FAUUSP, São Paulo, 1998.

O mito da fundação de Natal e a construção da cidade moderna segundo Manoel Dantas. Natal: Cooperativa Cultural, Sebo Vermelho, 2000.

SOARES, Jamilson A. Fragmentos do Passado: uma (re)leitura do urbano em Natal na década de 20. 1999. Dissertação (mestrado em Ciências Sociais) - CCHLA, UFRN, Natal, 1999.

SOUZA, Eloy de. (1925) Os ultimos cantadores do Nordeste. In FREYRE, Gilberto et al. Livro do Nordeste (Comemorativo do primeiro centenário do Diário de Pernambuco). 2 ed. fac-similar. Recife: Arquivo Público Estadual, p.66-67, 1979.

(1909) Costumes locais. Natal: Sebo Vermelho, 1999.

SOUZA, Itamar de. A República Velha no Rio Grande do Norte (1889-1930). Natal, s.n., 1989.

TAVARES DE LYRA, Augusto. (1921) História do Rio Grande do Norte. 3 ed. Natal: IHGRN, 1998.

Chorographia do Rio Grande do Norte. Rio de Janeiro: Brasileira Lux, 1924.

História do Rio Grande do Norte. Rio de Janeiro: Typographia Leuzinger, 1921.

O Rio Grande do Norte - 1911. Rio de Janeiro: Typ. do Jornal do Commercio, 1912.

TAVARES DE LYRA, Augusto e LEMOS, Vicente de. Apontamentos sobre a questão de limites entre os estados do Ceará e Rio Grande do Norte. Revista do IHGRN, Natal, Typographia d'O Século, vol. III, n.01, p.11146, jan. 1905 (a).

Revista do IHGRN, Natal, Typographia d'O Século, vol. III, n.02, p.231-402, jul. 1905 (b).

VIDAL, Maria S. C. A ponte da exclusão: os dois lados da cidade de Natal-RN. Natal: Cooperativa Cultura da UFRN, 1998.

VIVEIROS, Paulo P. História da aviação no Rio Grande do Norte. Natal: Universitária, 1974.

\section{Artigos de jornais ${ }^{1}$}

ALECRIM, Otacílio. Retractos da cidade. A República, Natal, 27 abr. 1929, n. 95, p. 01. (a)

Retractos da cidade II. A República, Natal, 03 maio 1929, n. 99, p. 01. (b)

01. (c)

O plano da Cidade de Natal - standard da Propaganda. A República, Natal, 22 ago. 1929, n. 190, p.

\footnotetext{
${ }^{1}$ Não tivemos acesso a todos os artigos de Câmara Cascudo, principalmente aqueles escritos n'A Imprensa entre 1920 e 1921 ; assim, utilizamos a bibliografia anotada e organizada por Zila Mamede (1970)
} 
ANDRADE, Mário de. As tradições e o Nordeste. A República, Natal, n.01, p.03, 01 jan. 1929.

BENTO, Antonio. As condições actuaes do RN. A República, Natal, 07 ago. 1929, n. 178, p. 01.

CASCUDO, Luis da Câmara. Musicalerias. A República, Natal, 14 jun. 1929, n. 132, p. 01.(a)

O novo plano da cidade I - a cidade. A República, Natal, 30 out. 1929, n. 247, p. 01.(b)

. O novo plano da cidade II - a Ribeira no "Master Plan". A República, Natal, 3 nov. 1929, n. 252, p.

01.(c)

Bric-á-brac. A República, Natal, p.01, 11 ago. 1927 in SOARES, Jamilson A. op. cit., 1999.

1920.

A grande verdade do pequeno livro "Como se hygienisaria Natal". A Imprensa, Natal, 5 e 8 jun.

DANTAS, Christovam. Impressões da America - a arte de embelezar as cidades. A República, Natal, 12 jul. 1923 , n. 196, p. 01.

DANTAS, Garibaldi. O "Vegecreto". A República, Natal, 8 maio. 1929, n. 102, p. 01. (a)

A utilidade dos planos grandiosos. A República, Natal, 18 jun. 1929, n. 135, p. 01. (b)

O urbanismo. A República, Natal, 17 set. 1929, n. 211, p. 01. (c)

DANTAS, Manoel. Os serviços da cidade. A República, Natal, n.247, p.01, 15 nov.. 1921.

FARIA, Maria Amalia de. O congresso Panamericano de Architectos. A República, Natal, 16 jul. 1930, n. 162, p. 01. (extrato d'O Paiz, 24.06.1930)

FILGUEIRA, Salomão. De Pernambuco. A República, Natal, 19 mar. 1929, n. 63, p. 01.

GUERRA, P. Colonos Nacionais. A República, Natal, n.68, p.01, 24 mar. 1929. (a) . A República, Natal, s/n, p.01, 04 abr. 1929. (b) - A República, Natal, n.78, p.01, 07 abr. 1929. (c) . A República, Natal, n.84, p.01, 14 abr. 1929. (d) A República, Natal, n.87, p.01, 18 abr. 1929. (e) . A República, Natal, n.93, p.01, 25 abr. 1929. (f) A República, Natal, n.94, p.01, 26 abr. 1929. (g)

IRWIN, Desbriere. Aviação postal no Brasil. A República, Natal, 07 set. 1929, n. 204, p. 01.

LABOREIRO, Simão de. Três horas em Natal. A República, Natal, 06 mar. 1929, n. 52, p. 01. (a) Azas que palpitam. A República, Natal, 27 mar. 1929, n. 70, p. 01-2. (b)

LAMARTINE, Juvenal. As boas orientações administrativas: o Rio Grande do Norte no governo Juvenal Lamartine (em entrevista). A República, Natal, 20 jul. 1930, n. 166, p. 01.

MELLO E SOUZA, Antonio J. Mensagem - Serviços urbanos de Natal. A República, Natal, n.254, p.01, 25 nov. 1921.

O'GRADY, Omar. Os problemas da cidade. A República, Natal, suplemento especial, 01 jul. 1929, n. 121, p. 01. A cidade que se renova (em entrevista). A República, Natal, 27 mar. 1930, n. 71, p. 01-02.

PALUMBO, Giacomo. A remodelação de Natal (em entrevista). A República, Natal, 24 fev. 1929, n. 44, p. 01.

PEREIRA, Francisco B. A crise asinaria da E. T. Força e Luz - A Saude Publica em perigo - salve-nos o Sr. Inspector de Hygiene. A Imprensa, Natal, n.444, p.01, 02 jul. 1916.

PORTINHO, Carmem Velazcos. Os progressos constantes da aviação. A República, Natal, 16 abr. 1929, n. 85, p. 01.

A participação do RN no $4^{\circ}$ Congresso Pan-americano de Architectura (em entrevista ao Jornal do Brasil, RJ). A República, Natal, 02 jul. 1930, n. 150, p.01. (a)

A remodelação de Natal. A República, Natal, 13 jul. 1930, n. 160, p.02. (b)

SANTIAGO, Varela. Letalidade em Natal. A República, Natal, suplem. especial, 01 jul. 1929.

VASCONCELLOS, Manuel A. P. A aviação do nosso paiz: aero-clubs e iniciativa norteriograndense. $A$ República, Natal, 09 maio 1929, n. 105, p.01. 
WANDERLEY, Jayme G. Rainha das “Urbs” Modernas. A República, Natal, 14 Mar. 1929, n. 59, p. 01.

\section{Mensagens de Governo (organizadas cronologicamente) ${ }^{2}$}

1851

WANDERLEY, João C. Relatorio apresentado a Assemblea Legislativa Provincial do Rio Grande do Norte. Pernambuco: Typographia de M. F. de Faria, 1851. 27 p.

1878

MARCONDE, Lobato. Mensagem do Presidente da Provincia do Rio Grande do Norte, s.l., s.n., 1878.

1890

SILVA GORDO, Adolpho A. Mensagem dirigida ao Congresso Constituinte do Estado do RN em 08 de Fevereiro de 1890. Natal, s.n., 1890.

1891

BARROS, Francisco Amintas da Costa. Mensagem dirigida ao Congresso Constituinte do Estado do RN em 10 de junho de 1891. Natal: Typographia do RN, 1891.

CASTRO, Miguel Joaquim de Almeida. Mensagem dirigida ao Congresso Legislativo do Estado do RN em 20 de setembro de 1891. Natal: Tupographia do RN, 1891.

1892

SILVA, Manoel Nascimento Castro e CHAVES F. ${ }^{\circ}$, Joaquim Ferreira (junta governativa). Mensagem dirigida ao Congresso Legislativo do Estado do RN em 20 de fevereiro de 1892. Natal: Typ. d'A Republica, 1892.

1893

MARANHÃO, Pedro Velho de Albuquerque. Mensagem dirigida ao Congresso Legislativo do Estado do RN em 14 de junho de 1893. Natal: Typ. d'A Republica, 1893.

1894

MARANHÃO, Pedro Velho de Albuquerque. Mensagem dirigida ao Congresso Legislativo do Estado do RN em 14 de julho de 1894. Natal: Typ. d'A Republica, 1894.

1895

MARANHÃO, Pedro Velho de Albuquerque. Mensagem dirigida ao Congresso Legislativo do Estado do RN em 31 de janeiro de 1895. Natal: Typ. d'A Republica, 1896.

MARANHÃO, Pedro Velho de Albuquerque. Mensagem dirigida ao Congresso Legislativo do Estado do RN em 14 de julho de 1895. Natal: Typ. d'A Republica, 1895.

1896

FERREIRA CHAVES, Joaquim. Mensagem dirigida ao Congresso Legislativo do Estado do RN em 15 de julho de 1896. Natal: Typographia d'A República, 1896.

1897

FERREIRA CHAVES, Joaquim. Mensagem dirigida ao Congresso Legislativo do Estado do RN em 14 de julho de 1897. Natal, Typ. d'A República, 1897.

1898

FERREIRA CHAVES, Joaquim. Mensagem dirigida ao Congresso Legislativo do Estado do RN em 14 de julho de 1898. Natal, Typ. d'A República, 1898.

1899

FERREIRA CHAVES, Joaquim. Mensagem dirigida ao Congresso Legislativo do Estado do RN em 14 de julho de 1899. Natal, Typ. d'A República, 1900.

1900

${ }^{2}$ Esta série documental pode ser consultada na Biblioteca Nacional do Rio de Janeiro e no Instituto Histórico e Geográfico do Rio Grande do Norte. 
MARANHÃO, Alberto. Mensagem lida perante o Congresso Legislativo do Estado do RN. Natal, Typ. d’A República, 1900.

1901

MARANHÃO, Alberto. Mensagem lida perante o Congresso Legislativo do Estado do RN em 14 de Julho de 1901. Natal, Typ. d'A República, 1904.

1902

MARANHÃO, Alberto. Mensagem lida perante o Congresso Legislativo do Estado do RN em 14 de Julho de 1902. Natal, Typ. d'A República, 1904.

1903

MARANHÃO, Alberto. Mensagem lida perante o Congresso Legislativo do Estado do RN em 14 de Julbo de 1903. Natal, Typ. d'A República, 1905.

1904

MARANHÃO, Alberto. Mensagem lida perante o Congresso Legislativo do Estado do RN em 25 de Março de 1904. Natal, Typ. d'A República, 1905.

TAVARES DE LYRA, Augusto. Mensagem lida perante o Congresso Legislativo do Estado do RN em 14 de Julho de 1904. Natal, Typ. d'A República, 1905.

1905

TAVARES DE LYRA, Augusto. Mensagem lida perante o Congresso Legislativo na abertura da sessão extraordinária de 22 de Janeiro de 1905. Natal, 1905.

TAVARES DE LYRA, Augusto. Mensagem lida perante o Congresso Legislativo a 14 de julho de 1905. Natal, Typ. d'A Republica, 1906.

1906

TAVARES DE LYRA, Augusto. Mensagem lida perante o Congresso Legislativo a 14 de julho de 1906. Natal, Typ. d'A Republica, 1907.

1907

MELLO E SOUZA, Antonio J. Mensagem apresentada ao Congresso Legislativo a 01 de Novembro de 1907. Natal: Typographia d'A Republica, 1907.

1908

MARANHÃO, Alberto. J. Mensagem apresentada ao Congresso Legislativo a 01 de Novembro de 1908. Natal: Typographia d'A Republica, 1908.

1909

MARANHÃO, Alberto. Mensagem apresentada ao Congresso Legislativo a 01 de Novembro de 1909. Natal: Typographia d'A Republica, 1909.

1910

MARANHÃO, Alberto. Mensagem apresentada ao Congresso Legislativo em 01 de Novembro de 1910. Natal: Typographia d'A Republica, 1910.

1911

MARANHÃO, Alberto. Mensagem apresentada ao Congresso Legislativo em 01 de Novembro de 1911. Natal: Typographia d'A Republica, 1911.

1912

MARANHÃO, Alberto. Mensagem apresentada ao Congresso Legislativo em 01 de Novembro de 1912. Natal: Typographia d'A Republica, 1912.

1913

MARANHÃO, Alberto. Mensagem apresentada ao Congresso Legislativo em 01 de Novembro de 1913. Natal: Typographia d'A Republica, 1913. 
FERREIRA CHAVES, Joaquim. Mensagem apresentada ao Congresso Legislativo em 01 de Novembro de 1914. Natal: Typographia d'A Republica, 1914.

1915

FERREIRA CHAVES, Joaquim. Mensagem apresentada ao Congresso Legislativo em 01 de Novembro de 1915. Natal: Typographia d'A Republica, 1915.

1916

FERREIRA CHAVES, Joaquim. Mensagem apresentada ao Congresso Legislativo em 01 de Novembro de 1916. Natal, 1916.

1917

FERREIRA CHAVES, Joaquim. Mensagem apresentada ao Congresso Legislativo em 01 de Novembro de 1917. Natal, 1917.

1918

FERREIRA CHAVES, Joaquim. Mensagem apresentada ao Congresso Legislativo em 01 de Novembro de 1918. Natal, Typ. d'A República, 1918.

1919

FERREIRA CHAVES, Joaquim. Mensagem apresentada ao Congresso Legislativo em 01 de Novembro de 1919. Natal, Typographia Comercial J. Pinto e Cia., 1919.

1920

MELLO E SOUZA, Antonio J. Mensagem lida perante o Congresso Legislativo em 01 de Novembro de 1920. Natal, Typographia Commercial J. Pinto e Cia., 1920.

1921

MELLO E SOUZA, Antonio J. Mensagem lida perante o Congresso Legislativo na abertura da $1^{a}$ Sessão da $11^{a}$ Legistatura em 01 de Novembro de 1921. Natal, Typographia Commercial J. Pinto e Cia., 1921.

1922

MELLO E SOUZA, Antonio J. Mensagem lida perante o Congresso Legislativo na abertura da $2^{a}$ Sessão da $11^{a}$ Legistatura em 01 de Novembro de 1922. Natal, Typographia Commercial J. Pinto e Cia., 1922

MELLO E SOUZA, Antonio J. Mensagem lida perante o Congresso Legislativo em 01 de Novembro de 1923. Natal, 1920.

MEDEIROS, José A. B. Mensagem lida perante o Congresso Legislativo em 01 de Novembro de 1924. In Mensagens dos Presidentes do Estado do Rio Grande do Norte na Primeira Republica, VIII, Coleção Documentos Potiguares, n.16. Natal: Fundação José Augusto; Brasília: Centro Gráfico do Senado Federal, p.11-70, 1984.

MEDEIROS, José A. B. Mensagem lida perante o Congresso Legislativo em 01 de Novembro de 1925. In Mensagens dos Presidentes do Estado do Rio Grande do Norte na Primeira Republica, VIII, Coleção Documentos Potiguares, n.16. Natal: Fundação José Augusto; Brasília: Centro Gráfico do Senado Federal, p.71-125, 1984.

1926

MEDEIROS, José A. B. Mensagem lida perante o Congresso Legislativo em 01 de Outubro de 1926. In Mensagens dos Presidentes do Estado do Rio Grande do Norte na Primeira Republica, VIII, Coleção Documentos Potiguares, n.16. Natal: Fundação José Augusto; Brasília: Centro Gráfico do Senado Federal, p.127-184, 1984.

\section{7}

MEDEIROS, José A. B. Mensagem lida perante o Congresso Legislativo em 01 de Outubro de 1927. In Mensagens dos Presidentes do Estado do Rio Grande do Norte na Primeira Republica, VIII, Coleção Documentos Potiguares, n.16. Natal: Fundação José Augusto; Brasília: Centro Gráfico do Senado Federal, p.185-309, 1984.

1928

LAMARTINE DE FARIA, Juvenal. Mensagem apresentada à Assembléia Legislativa em 01 de Outubro de 1928. Natal: Imprensa Official do Estado, 1928.

1929 
LAMARTINE DE FARIA, Juvenal. Mensagem apresentada à Assembléia Legislativa em 01 de Outubro de 1929. Natal: Imprensa Official, 1929.

1930

LAMARTINE DE FARIA, Juvenal. Mensagem apresentada à Assembléia Legislativa em 01 de Outubro de 1930. Natal: Imprensa Official, 1930.

Periódicos consultados

(local de publicação, ${ }^{3}$ período pesquisado)

Gazeta do Natal (1888-1890), A Patria (1890), A República (1890-1932), Quinze de Novembro (1890), Tribuna Juvenil (1890), O Nortista (São José do Mipibu, 1892), Oásis (1894-1899); Diário de Natal (19001912), Revista do Instituto Histórico e Geográfico do Rio Grande do Norte (1903-1921), O Arurau (1905), O Pyrilampo (1905), O Trabalho (1905), Ze-Povinho (1905), O Progresso (Currais Novos, 1906), Gazeta do Commercio (1907), Gazeta de Macau (Macau, 1909), O Torpedo (1909), O Gondolas (1910), Correio do Seridó (Caicó, 1910-1911), Argos (1912), O Binóculo (1912), O Echo (1912), O Martello (1912, 1914), O Telephono (1912), A Cruz (1913), A Encrenca (1913), A Lavoura (Ceará-Mirim, 1913), Folha Nova (Macau, 1913), Gazeta do Sertão (Villa das Flores, 1913), Gazeta da Tarde (1913), Jornal da Manhã (1913), A Avenida (1914), Diário de Noticias (1914), O Espectador (1914), O Prego (1914), Gazeta da Semana (1914), Aeroplano (1915), A Liberdade (Nova Cruz, 1915), A Urucubaca (1915), O Alfinete (1915), A Platea (1916), A Imprensa (1917-1920), Boletim de Instrucção (1918, 1924), O Imparcial (Macau, 1918), O Momento (1918), Natal-Jornal (1919), O Sportivo (1919), A Pua (1920), O Bandeirante (1920), O Fon-fon (1920), A Cathedral (1921), Revista do Centro Polymathico (1920), A Noticia (1921), A Palavra (1921, 1932), Jornal do Norte (1921), O Leme (1921), O Commercio (1924), O Democrata (Nova Cruz, 1924), O Commerciario (1928), Revista de Antropofagia (São Paulo, 1928-1929), Architectura e Construcções (São Paulo, 1929-1930), Revista Brasileira de Engenharia (Rio de Janeiro, 1929-1930), Revista do Club de Engenharia (São Paulo, 1929-1932, 1934-35), Revista Politécnica (São Paulo, 1929-1937), O Cabuji (Angicos, 1930), O Paiz (Rio de Janeiro, 1930), Revista de Engenharia Mackenzie (São Paulo, 1930-1933), O Dardo (Mossoró, 1931), Revista da Directoria de Engenharia - PDF (Rio de Janeiro, 1932-1943), Arquitetura e Urbanismo (Rio de Janeiro, 1936-1937), Aviation (EUA, 1941-42), Aviação (Rio de Janeiro, 1942-43).

Outros documentos históricos

CASTELBRANCO, Basilico de. Diccionario Contemporaneo da lingua portugueza. Lisboa: Livraria Editora, 1918.

CONSTANCIO, Francisco S. Diccionario critico e etymologico da lingua portugueza. Paris: Tor, 1836.

FIGUEIREDO, Candido de. Novo diccionáro da Lingua portuguesa. vol. 1. Lisboa: Livraria Clássica Editor, 1913.

REIS, Aarão. Obras Novas Contra as Sêcas (relatório apresentado ao Ministro de Viação e Obras Públicas sobre as obras executadas entre 3 de setembro de 1915 e 31 de outubro de 1918). Rio de Janeiro: Imprensa Nacional, 1920.

“As sêcas no Nordeste”. In Obras Novas Contra as Sêcas (relatório apresentado ao Ministro de Viação e Obras Públicas sobre as obras executadas entre 3 de setembro de 1915 e 31 de outubro de 1918). Rio de Janeiro: Imprensa Nacional, p.223-246, 1920.

\footnotetext{
${ }^{3}$ Todas as publicações são de Natal, salvo indicação em contrário.
} 
Anexos 


\title{
Artigos originais transcritos (publicados no jornal A República)
}

\author{
CASCUDO, Luís da Câmara. O Novo plano da Cidade - I - A Cidade. A República, \\ Natal, n.247, p.01, 30 out. 1929. \\ Officialmente existe a Cidade do Natal ha tresentos e trinta annos. Relativamente parece com \\ este titulo há oito ou nove annos. Ou melhor, imita cidade recem fundada, se o \\ enviesamento das arterias não denunciasse a velhice.
}

O "chão elevado e firme" onde se plantou a cidade é a praça André de Albuquerque. A Ribeira permaneceu sempre um mixto de commercio e de casas raras que as grandes cercas distanciavam. O Potengy, caminho de venda para Pernambuco, abrigou a fila de casinhas seguindo o curso. A conquista do leste é modernissima. Nós podemos dizer que a cidade se dividiu em tres "blocos". O da Ribeira, o da Cidade-Alta, o Ribeirinho. Petropolis, Tyrol e Alecrim não podem entrar no computo porque são recentes. Inda vive quem assistiu a construcção da primeira residencia em Tyrol, das primeiras casas em Petropolis (nomes de sitios do governador Alberto Maranhão) quem caçou cotias na actual praça Pedro Velho e jacus na avenida Hermes.

Os tres "blocos" estendem-se numa irregularidade coherente. Havia a coherencia do factor economico que era a facil remessa dos productos pela via maritima. A cidade segregada entre morros e mar não tinha sinão vagas nocções de commercio de interior que se escoava rumo ao sul, nos comboios lentos partidos do Seridó ou vindos do Piauhy atraves de Ceará e Rio Grande do Norte, via Assú.

A cidade isolada guardava tenues liames interprovinciaes. O Potengy que dera nome á região, indicava o futuro da terra guiando para o mar os recursos realisados.

A cidade teve bem cedo o aspecto que hoje conserva em traço geral. O "bloco" ribeirinho estendeu-se da Praticagem ao Oitizeiro. O segundo, a Ribeira, ganhou profundidade indo esbarrar nos areaes das Roccas e para leste com Areial, dahi, em curva lenta, articulando-se numa continuidade de cochicholos, espraiava-se nos taboleiros cobertos de cajueiros bravos e mangabas.

O terceiro "bloco", tirante a "subida da ladeira", a Rua da Cruz, era o maior bairro, o bairro residencial e de commercio meúdo.

Tivemos desta forma tres direcções para uma cidade pequena. Em 1873 inda se dizia Cidade do Natal? Não ha-tal! O amontoado de casario plantado a vontade dentro de allinhamentos invisiveis deu bem cedo o plano disparatado d'uma cidade em curvas, obliquas e angulos agudos.

As rectas traçadas afoitamente são attitudes modernas ou exigencias imperiosas duma situação topographica que não consentiu que a indifferente attenção dos homens desvirtuasse o que naturalmente estava feito.

Dahi a Rua da Cruz, Junqueira Ayres, João Manuel, Conceição e Rua Nova. O nome dispensa provanças de modernidade relativa.

O que Natal apresenta actualmente é a ligação dos tres "blocos" iniciaes com a teia de aranha das ruas irracionaes. Depois da André de Albuquerque, descendo para o rio, a tortuosidade das ruas lembra um delirio de linhas convulsas. São as paralellas Paula Barros e Presidente Ramos e a da Misericordia, riscos á doida, quebrados, tortos, alinhando filas de casas que parecem ter sido fixadas á murro. É a obliquidade da rua Ferreira Chaves. A incrivel sinuosidade da Felippe Camarão, o desmantelo da do Commercio (que Sampaio Correia pediu como remediu um phosphoro e duas latas de kerozene), o angulo agudo formado pela Felippe Camarão com a da Boa Vista findando na montanha russa da Bicco-da-Telha, são os exemplos dos caminhos tremulos e indecizos das cidades doentes de colloração esthetica.

A cidade em conjunto poderia ser explicada em dois grandes arcos. Um antigo, irregular, atribilario, incorrigivel em todo, parte irracional, parte iniciadera da cidade centenaria, arco cujas extremidades tocam as Roccas e o Baldo. A recta partida destes extremos marca a 
verdadeira cidade do Natal. O outro arco, parte moderna, já racciocinada, um pouco moderna pela sisudez geometrica do enxadrezado, terá seus extremos tocando os dois do primeiro arco e correndo de leste a sul enquanto o primeiro parte de norte a oeste.

A conquista das primeira praças, Augusto Severo e Leão XIII que eram pantanaes, o alinhamento da Silva Jardim que era um alagado, trouxe o pensamento do xadrez porque este partida da idéia do primeiro retangulo saneado, plantado e conquistado ao rio. A recta surgiu como uma expressão de segurança. A Tavares de Lyra já demonstra isto. Os fulcros seriam as rectas que partindo do rio subissem para o morro. $\mathrm{O}$ desenho geometrico iniciou-se inda timido mas coherente e seguro. Tavares de Lyra - Silva Jardim - Sachet - Dr. Barata. A lucta daria a visão do rio, inimigo tradicional e alliado consideravel. O prolongamento da Sachet aceitou o plano inconsciente e primitivo do começo do xadrez. Manoel Dantas que morou no Natal velho sonhou em 1909 a Ribeira "enxadrezada".

A cidade do Natal, entre rio e morro, ficou como uma massa esperando o aspecto. O titulo já possuia desde 1599.

CASCUDO, Luís da Câmara. O Novo plano da Cidade - II - A Ribeira no 'Master Plan. A República, Natal, n.252, p.01, 07 nov. 1929.

O "Master Plan" que o sr. Omar O’Grady entregou ao technico Palumbo é a utilisação da massa citadina num plano racional de correcção. Correcção na parte existente. Os elementos constitutivos num trabalho de urbanismo serão forçosamente aquelles que se relacionem e aperfeiçoem o aspecto esthetico da cidade aproveitando seus recursos em paysagem e conjuncto, a facilidade de circulação e viação urbanas, os transportes e os recreios. A existencia do "zoning" e a inevitável arte cívica, dão a demão derradeira. O "master plan" em sua primeira plancha dá a impressão de intelligente resultado destes elementos. Os accessos á Cidade Alta passarão a quatro. A circulação será garantida pela amplidão das ruas e avenidas. O aspecto total apresentará uma harmonia da nossa Cidade tradicional com sua paysagem corrigida pela intelligencia.

Não estamos na phase eterna do "paper dreams". Uma forte attitude de realisação pede naturalmente a collaboração das solidariedades collectivas. Urbanismo é justamente the science of linking up connection between things. A phrase é de Urwin [sic. R. Unwin, na verdade].

Um "master plan" não é uma luva que se applique immediata e totalmente sobre a mão. É passível de remodelações e de concessões. É um programma que póde e deve ser alterado em detalhes. No mais é como uma lei de bom gosto que se seguirá no curso da vida material da cidade. Não se pretende estabelecer um dogma definitivo em assumpto urbanistico. Os americanos são assim. Riscam uma cidade e constroem-na. Como quem ergue um bôlo. Assim reconstruiram S. Francisco da California e reformaram Oakland. Assim os ingleses fizeram na moderna capital australiana de Camberra.

Parece que em Natal seguir-se-ha o conselho do professor Steinhoff, da Universidade de Viena. Para Steinhoff não é possível determinantes porque uma cidade é um organismo vivo que cresce sob a influencia multipla de elementos tambem variaveis, como o factor economico, a idéa pessoal dos dirigentes, a moda architectural, etc.

Mas o que será a Ribeira quando o "master plan" estiver victorioso materialmente?

Começa o passeio pelas parallelas ao rio Potengy. As ruas que cahem perpendicularmente sobre o rio serão vistas em segundo lugar.

Rua do Commercio. Terá o mesmo comprimento. Será corrigida. Soffre duas deflexões, duas passagens obrigadas na Tavares de Lyra e Ferreira Chaves que hoje não vem até o rio. Corre a Commercio desde a Central até a Praticagem. Dahi em diante seguirá com outro nome, numa outra avenida que figurará na cidade novissima das Dunas. Terá, quando corrigida, uma praça-caes que servirá para as pequenas embarcações. Onde é a velha Alfandega. Os quarteirões da Commercio serão cinco, em tamanho decrescente. Trez travessas 
communicarão com o rio. Actualmente a Commmercio não tem sinão o inutil e esquecido caes do Palacio. Uma outra praçuela ajardinada cahirá sobre o eixo da Ferreira Chaves. Ficará a Commercio com seis accessos para o Potengy. E pequenos parques á beira rio.

Rua Dr. Barata seguirá corrigida. Conservar-se-hão as travessas Venezuela, Argentina e Quintino Bocayuva que será alargada.

Rua Frei Miguelinho. Mesmo tamanho e direcção. As ruas transversaes Nysia Floresta, Ferreira Chaves e Triumpho que vêm agora atravessando a Sachet e terminando na Frei Miguelinho terão uma valorização inesperada. As duas primeiras irão até o rio, coincidindo na articulação das travessas da rua do Commercio. O final da Frei Miguelinho é a Silva Jardim. Dahi em diante é o domínio de um plano ideal, dum plano de extensão, desdobrando os horizontes da cidade do Natal.

Senador Bonifácio, a rua das Virgens, alinha-se, acerta-se e ponto final.

Avenida Sachet será uma caracteristica de belleza simples e de amplidão magnifica. Virá desde a Junqueira Ayres, cortará o parque Augusto Severo fazendo triangulos rectos e isoseles, atravessa a Tavares de Lyra, Nysia Floresta, Ferreira Chaves, 15 de Novembro (por que se mudou o nome de Triumpho?) e irá em recta até a Silva Jardim. Como a Frei Miguelinho e Commercio a Sachet fixar-se-ha numa immensa avenida contornante que abraçará Natal.

Almino Affonso. Rua irregular. Rua dançando charleston. Entrará uma linha razoavel de decencia e de ordem. Virá em recta com a largura de 18 metros desde o contorno da Silva Jardim (a Almino hoje é uma rua de novello em mão de macaco) até intestar-se com o inicio da Avenida Rio Branco que terá passado os terrenos da Villa Barretto. Um becco que é a curava do Triumpho, a pracinha onde está a Prophylaxia, desaparecerão. A Almino ficará, ao avistar a Rio Branco que agora vem morrer deante do Bom Jesus da Ribeira depois das soluções de continuidade da Villa Barretto, etc., etc., numa praça nova que substituirá a actual Leão XIII. A Almino ficará nesta praça que deixará o Bom Jesus isolado e com um outro aspecto de imponencia e expressão architectural.

O novo quarteirão que substituirá a praça Leão XIII terá como limites as ruas Nysia Floresta, Sachet, Tavares de Lyra e a futura praça. Nesta, no lado sul virá a Rio Branco que passando as ruas Sul e Norte (lado direito da Domestica e direito do Carlos Gomes) attingirá ahi o seu terminus.

A rua General Glycerio (por que este nome?) ficará rectificada.

$\mathrm{E}$ as ruas perpendiculares ao rio? A rua Sul irà ligar-se na rua da Felippe Camarão. Ella actualmente existe até a cota 5 mas é impraticavel. Tem 16 metros. O prolongamento da praça Augusto Severo chamado Travessa Aureliano terá 16 metros. Estender-se-há até a avenida Deodoro passando a rua Norte. Agora ella possue este mesmo traçado, é de quasi impossivel subida. Este prolongamento será uma via de ligação desde a Deodoro até o Potengy. Justamente neste local estará o caes que substituirá o da Praticagem. De mim mesmo encontro nestes 16 metros uma largura que não satisfará futuramente a necessidade do trafego cada vez maior. Dentro de dez annos a Prefeitura terá que ampliar este algarismo. Mesmo agora a travessa já é de circulação intensa e nos dias de trem coincidindo com as vindas de algodão e embarque para a Great Western sua estreiteza é asphyxiante. Os 16 metros serão paliativos. Melhor seria remediar de vez.

A Tavares de Lyra continuara com seus 22 metros até a cota 5 , passando à direita da praça que isolará egreja Bom Jesus e terminará num local reservado para monumento. As ruas Nysia Floresta e Ferreira Chaves subirão até a avenida Deodoro.

A Silva Jardim vai até a cota 5 e se confundirá com o prolongamento da Deodoro. Uma "reserva" dará o futuro mercado do bairro-baixo. A Silva Jardim é rua-grande na cidade novissima que fará esfarelar-se os arruados das Roccas, Areial, Limpa, Canto do Mangue, Chama-maré, etc.

Por ora só se passeiou na Ribeira Systematizada. A impressão é de audacia muito respeitoza. Tudo ou quasi tudo se poupou. Os traçados obedeceram a linha tradicional parallelas e 
verticaes ao rio. Apenas o braço do homem alinhou raciocinadamente os valores confuzos que herdamos em nome da cidade.

O'GRADY, Omar. Os problemas da cidade. A República, Natal, suplem. esp., n.121, p.01, 01 jul. 1929.

Serve hoje de base para comparação do progresso das cidades o que se há convencionado chamar o coefficiente de calcamento. Este coefficiente nada mais é do que o numero de metros quadrados de calçamento que corresponde a cada habitante de uma cidade. Para que este coefficiente, no entanto, exprima verdadeiramento o grau de desenvolvimento de uma cidade torna-se necessario tomar em conta a natureza, ou typo, do calçamento, pois muito mais vale um coefficiente 5 para calçamento de typo superior do que um coefficiente 10 resultante, no todo ou na sua quase totalidade, de pavimentação de alvenaria irregular ou simples empedramentos, que recebem, sempre, as honras de calçamento no seu sentido rigoroso.

Pelos dados que temos em mãos verificamos que este indice, em média, é de 6 nas cidades allemães, de 9 nas cidades americanas, que em S. Paulo é cerca de 6, e em Bello Horizonte 5,2. Considera-se, ainda, como satisfactorio, um coefficiente de 10 para as cidades de pequena densidade. Ha varias cidades americanas desta cathegoria que attingiram a 14.

Comparemos, agora, os indices acima com o da nossa capital. Temos, actualmente, 100466 metros quadrados de calçamento para uma população de 35000 habitantes, sendo, portanto, o nosso coefficiente

$\underline{100466}=2,87$

35000

Isto tomando-se em consideração o total de area calçada (inclusive empedramentos); se, porem, considerarmos, apenas, a area calçada a parallepipedos e macadame pixado, que é de 26955 metros quadrados, temos

$\underline{26955}=0,77$

35000

que deveria ser o nosso verdadeiro e significativo indice de calçamento, porque os calçamentos que não foram considerados para este calculo, na sua maioria, quase não merecem o nome. É portanto muito baixo o nosso coefficiente de calçamento.

Foi comprehendendo a significação e a importância do problema de calçamentos que o actual governo da cidade fez do mesmo ponto principal do seu programma de realizações. Com effeito, nos ultimos quatro annos a administração municipal fez construir 36600 metros quadrados de calçamento, sendo 21016 de typo superior (parallelepipedos e macadame pixado) e 15644 de alvenaria irregular. Isto quer dizer que já durante a actual administração fez-se $36 \%$ do total da area pavimentada que tem a cidade.

Estes algarismos, conquanto pareçam animadores quando comparados com o que encontramos feito em materia de calçamentos, são ainda insignificantes quando tivermos de consideral-os sob o ponto de vista das exigencias provenientes do desenvolvimento da cidade, ou comparal-os com os indices de calçamento das cidades a que acima nos referimos. E escolhemos, muito de proposito, para base de nossa comparação as medias de cidades em paizes como a Allemanha e os Estados Unidos, e dentre as nossas S. Paulo e Bello Horizonte, porque deve servir de padrão aquillo que já attingiu um certo grau de perfeição, e nunca o que está em plano baixo, semelhante, apenas, á cousa comparada. Não nos devem interessar os indices de calçamentos em cidades de paizes atrazados, ou os das nossas proprias cidades mais rotineiras. Como, tambem, não devemos nos conformar com os erros ou falhas de outros. Não devemos ficar satisfeitos porque ha outras cidades de nosso paiz com coefficientes menores do que o nosso, nem porque ha cidades, como, por exemplo, 
Fortaleza que não possuem outro calçamento que não seja o empedramento commum sobre areia.

Alem de estabelecer as condições de trafego e de superficies de rolamento compativeis com o desenvolvimento cada vez maior da autoviação, intensificado hoje com o transporte collectivo por meio dos autos-omnibus, devemos considerar que um bom calçamento transforma por completo o aspecto de uma rua, dando-lhe uma feição alegre com a construcção de novos passeios, corrigindo com o assentamento dos meios-fios os pequenos erros de alinhamento, acertando definitivamente o seu grade, resolvendo a drenagem das aguas pluviaes que resulta tambem na solução de pequenos problemas de saneamento, e realizando afinal, varios outros pequenos serviços complementares de aformozeamento, inclusive a arborização e illuminação, cujo conjuncto completa a transformação da rua, serviços estes que são sempre levados a effeito com a construcção definitiva de um bom calçamento. Para exemplo basta citarmos, sem commentario, os casas das Avenidas Junqueira Ayres, Atlantica e Sachet (apenas começada), praça Augusto Severo e ruas Dr. Barata e José Bonifácio. Não precisamos insistir na valorização da propriedade beneficiada com o calçamento na rua em que está localizada. A valorização é uma consequencia tão immediata e tão certa que não ha espirito por mais rotineiro e pessimista que seja que, de bôa fé, ouze contestal-a.

Estamos, felizmente, em situação relativamente facil para darmos solução ao nosso problema de bons calçamentos.

Quando falamos em bons calçamentos queremos nos referir a parallelepipedos, sobre base de concreto ou de macadame, conforme as condições do grade e de trafego, pois, para as condições especiaes do nosso meio, é este o typo ideal.

Com a permissão do governo federal temos um trecho da pedreira de Macahyba que nos fornece um granito ideal para parallelepipedos, cujo transporte de 20 kilometros por via fluvial é facil e economico. Quanto á mão de obra de pedreira, graças á organização dada com o aproveitamento de um pequeno numero de bons operarios de fora e ensinando aos nossos proprios operarios, que aprendem com relativa facilidade e disciplina, conseguimos, por meio do regimem de tarefas, preços menos altos do que os do sul do paiz. O mesmo se dá com a mão de obra do assentamento, ou construcção propriamente dita do calçamento.

O financiamento da construcção de calçamentos, que é funcção da capacidade orçamentaria do Municipio, está, naturalmente, por esta limitada, limite este que está muitas vezes aquem do que continua a exigir o desenvolvimento da cidade. Contudo, com a resolução n ${ }^{\circ} 290$ de 13 de Setembro de 1928, que faz dividir de uma maneira suave e equitativa, com os proprietarios beneficiados os encargos provenientes da pavimentação das ruas, tornou-se mais facil para a Prefeitura realizar um programma mais extenso e um pouco menos afastado das necessidades da cidade. É-nos grato registrar que esta resolução municipal tem encontrado bôa acceitação por parte da quase totalidade dos proprietarios, que, com intelligencia, estão comprehendendo a sua alta finalidade utilitaria.

A pavimentação das ruas da nossa cidade contiua a ser um dos seus mais serios problemas e para solução do qual a Prefeitura está a dispender a maior parcella dos seus esforços e dos seus recursos.

Varios outros problemas, de ordem material, interessam intimamente a vida da cidade, alguns de importancia quase igual ao dos calçamentos, como sejam a construcção de um matadouro e de um novo mercado, restabelecimento da regularidade dos serviços de illuminação, força e viação urbanas, um novo serviço de abastecimento d'agua e construcção de uma rede de esgotos sanitarios. Alguns desses serviços podem esperar solução por mais tempo, tendo em vista a capacidade financeira do municipio e a propria necessidade dos mesmos em relação á população e movimento actuaes da cidade. Outros que estão sendo explorados pelo Estado, que pela somma vultosa que requerem para sua soleção só podem ser mesmo atacados pelo governo estadual, continuam a esperar deste a sua solução definitiva. 
Afora o que diz respeito á execução dos serviços materiaes ou construcções de vulto para attender ás necessidades reclamadas pelo desenvolvimento da cidade vemos um grande problema de cuja solução a Prefeitura já cuidou.

Referimo-nos a execução do plano definitivo da cidade. Uma cidade como a nossa, cheia de ruas irregulares e mal dispostas, não deve continuar a se desenvolver sem que se obedeça a um projecto que consulte os actuaes preceitos de urbanismo. É assim que a Prefeitura contractou com um urbanista a execução de um plano definitivo de cidade, visando o futuro desenvolvimento de nossa capital. Não se trata exactamente de um "plano grandioso" daqueles que Garibaldi Dantas, ha poucos dias n'A REPUBLICA, reclamava para as nossas cidades, mas, apenas de um modesto plano de systematização e extensão para evitar que o aggravamento de certos factores encareça difficulte ou [ilegível], quasi que impossibilite a solução, no futuro, dos nossos problemas de urbanismo, não recahindo sobre nós censurar por termos sidos imprevidentes. De par com o projecto da cidade - e hoje nada se executa sem projecto -cuidamos de um regulamento para construcções, cujo anti-projecto já elaborámos e apresentámos á consideração da Intendência Municipal.

O plano e o regulamento se completam para assegurarem o desenvolvimento da cidade dentro dos limites de urbanismo e de esthetica que os nossos fóros de cidade não permittem sejam por mais tempo violados.

PALUMBO, Giacomo. A Remodelação de Natal: perspectivas sobre a cidade futura (em entrevista) A República, Natal, n.44, p.01, 24 fev. 1929.

Antes de haver regressado para o Recife, onde tem actualmente o seu escriptório technico, o illustre engenheiro Giacomo Palumbo deu gentilmente, a este jornal, as suas impressões sobre a nossa capital, dum ponto de vista geral, demorando, entretanto, as suas observações e as variadas suggestões que nos foi fazendo, principalmente sobre as perspectivas immediatas do nosso desenvolvimento urbano.

Não precisamos encarecer daqui o nome e a competência profissional do sr. Palumbo, a quem a visão administrativa do sr. Presidente do Estado, de accordo com o sr. Prefeito Omar O'Grady, acaba de confiar o estudo dum plano completo de remodelação da cidade.

Tanto o Presidente Lamartine como o Prefeito Omar O'Grady estão directamente interessados pelo desenvolvimento rapido que a nossa capital vae forçosamente ter, como ponto de convergencia da aviação tri-continental, nestes tempos de formidavel intensificação do transporte aereo, de modo que o convite feito áquelle illustre technico para visitar esta cidade foi o mais opportuno e acertado.

Trata-se realmente dum engenheiro architecto e technico em assumptos de urbanismo de invulgares qualidades profissionaes com uma cultura especialisada bem solida, e dotado desse golpe de vista prompto e seguro que o seu métier requer.

Ouvimol-o por espaço duma meia hora discorrendo sobre a nossa cidade e, da nossa conversa que com elle mantivemos, vão abaixo resumidas algumas de suas mais importantes observações.

\section{Natal como cidade}

- Em urbanismo, clássico e moderno, começou dizendo-nos o sr. Palumbo, a cidade ideal deve ter do ponto de vista theorico duas partes bem distinctas, ou melhor, uma parte baixa e outra alta.

Naquella, deve ficar localisado o commercio e nesta os bairros de residencia particular.

Ora, Natal, apezar de certas irregularidades e de alguns ligeiros defeitos naturaes, satisfaz plenamente ás exigencias geraes desse quadro schematico de urbanismo theorico. 
Assim, na Ribeira, deve ficar localisada toda a vida commercial da cidade e a sua parte alta, com os bairros de Petropolis e Tyrol, pode-se destinar para o corpo de habitação propriamente particular da capital.

$\mathrm{Na}$ Ribeira, antes de mais nada, deve se cuidar, prevendo-se o crescimento e a importancia que a cidade terá brevemente, do seu aspecto economico - de modo que o principal problema a ser encarado pela Prefeitura deve ser o do trafego, bem como a uniformisação das ruas, que devem ser adaptadas ás exigencias do movimento commercial.

E, na Cidade Alta, deve-se tratar antes de outra coisa, de tornar aprazivel e harmonioso o desenvolvimento de bairros de residencia commum, tornados bairros jardins, cortados aqui e alli de parques, que façam agradavel a alegria de viver.

Os edificios publicos devem ficar situados entre essas duas partes da Cidade, mais ou menos onde estão o Palacio do Governo e a Prefeitura, muito bem localisados.

Aliás, diga-se de passagem, o primeiro é um edificio classico bem apresentavel, com uma fachada simples, a qual, com algumas modificações, poderá tornar-se um palacio de aspecto realmente sympathico.

\section{O porto de Natal}

- Natal possue um porto excellente, de admiraveis condições naturaes.

E estando o ancoradouro justamente situado junto á parte commercial da cidade, é imprescindivel que se cuide não só de facilitar os seus serviços de caracter puramente technico, como tambem de tornal-o um bonito porto.

Actualmente, quem chega a Natal, pelo mar, tem, sem duvida nenhuma, uma má impressão porque, alem de não ver o minusculo cáes da Tavares de Lyra, só avista fundos inestheticos de casas mal construidas.

E isso é positivamente lamentavel.

Creio que se deveria cuidar de fazer, com a brevidade que fosse possivel, uma avenida á borda do Potengy, partindo do cáes da Alfandega actualemente em serviço, até um pouco alem do Passo da Patria.

É uma necessidade para o porto de Natal construir-se uma avenida arborisada com um largo passeio, á beira rio.

Bem como me parece indispensavel, pensando-se um pouco na evolução rapida que Natal terá, que se consiga retirar a "Great Western" e a "Central do Rio Grande do Norte" do local onde actualmente estão, pois enquanto permanecerem alli, impedirão fatalmente $\mathrm{o}$ desenvolvimento da Cidade nesse sentido.

Do contrário, a entrada de Natal, pela via ferrea, offerecerá o aspecto melancholico, ou por outra, desagradavel que hoje se observa.

E, antes de mais nada, Natal precisa de ter um bom cáes de desembarque, que deve ser um bella praça, de traçado moderno e constituida de preferencia por edificios publicos.

Convem não esquecermos que nestes proximos annos será ahi que pisarão o solo do Continente sul-americano os passageiros que vierem em hydro-avião da Europa, Africa e America do Norte.

Essa praça deve continuar por uma larga avenida, que finalisará por um monumento ou edificio publico de silhueta monumental, que lhe dará o nome, segundo o modelo classico, em urbanismo, da Avenida da Opera ou dos Campos Elysios, de Paris.

A Cidade está se desenvolvendo agora e, antes que seja tarde, é preciso que se destine um bom e amplo logar para o cáes futuro.

$\mathrm{E}$ isso parece-me, na verdade, importante.

\section{O trafego da Ribeira}

- O problema do trafego aqui, na Ribeira, merece toda a attenção. 
Não devemos esquecer que elle deve ser feito paralelamente ao cáes, quer dizer ao curso do Potengy e nunca concentrado numa rua vertical, ao mesmo tempo como, por exemplo, na Avenida Tavares de Lyra.

Assim, pela actual avenida Sachet ou por outra arteria larga que será talvez aberta, deverá se fazer futuramente o trafego atravez da Ribeira, livre, então, de qualquer congestionamento.

\section{Grandes sombras, gramados}

- Numa cidade tropical como esta, a ausencia de grandes sombras, de parques apropriados á terra e ao clima, não se justifica mais.

O principal problema a ser cuidado agora, em toda a Cidade Alta destinada á moradia particular, é esse da delimitação dos terrenos para construcção dos grandes parques, com arborisação apropriada que a tornarão no futuro uma cidade jardim.

Grandes sombras e gramados amplos por toda parte, ahi está uma necessidade imperiosa para Natal, afim de dotal-a de uma systema de jardins publicos que a torne uma cidade verdadeiramente graciosa.

\section{Praia do Meio, Areia Preta}

- Essas praias constituem um dos encantos principaes da cidade, por sua singular e pittoresca belleza natural. Serão futuramente um dos encantos principaes de Natal.

Sua decoração natural é tudo o que há de mais simples e attrahente: a massa alva das dunas colorida pela pincelada verde dos cajueiros e outros arbustos.

Falta apenas que a Prefeitura exija que sejam alli feitas casas adaptadas ao local, bem como promova a construcção dum Casino, mesmo modesto, pouco importa, no qual os touristas que tocarem aqui possam passar umas horas agradaveis.

Esse Casino será, ao mesmo tempo, o grande attractivo da cidade na temporada de verão.

\section{Necessidades inadiaveis}

- A Cidade tem algumas necessidades inadiaveis a attender

entre estas impõe-se , como todos devem saber, a construcção immediata dum bom hotel, para o qual aliás, já conclui uma planta que me parece irá agradar muito aos natalenses.

Trata-se dum edificio de quatro andares, com uma fachada simples mas de grande effeito que, se for construido, estou certo que esta capital ficará dotada dum melhoramento consideravel sobre todos os pontos de vista.

O serviço de pavimentação da cidade deve ser continuado incessantemente.

O novo calçamento feito pelo actual Prefeito é bom e me parece plenamente satisfatorio.

Outra coisa de que Natal se ressente muito é da ausencia de bons edificios publicos e isso constitui realmente uma das mais importantes necessidades de uma cidade.

Entre outros, creio que se deveria fazer aqui um palacio para o Tribunal de Justiça.

\section{Plano definitivo da cidade}

- Se se quér promover a remodelação de Natal, deve-se fazer desde já, antes de outra qualquer cousa, uma planta definitiva da cidade, com as modificações que ela terá de soffrer.

Isso é inadiavel, em materia de urbanismo.

É preciso estabelecer logo o plano dos trabalhos que serão executados agora e futuramente, afim de que tudo vá marchando coordenadamente.

Cumpre que esse plano seja organisado, em todos os seus detalhes, não só quanto ao traçado definitivo da cidade a ser observado daqui por deante, como tambem com referencia ás questões de detalhe como sejam uniformisação dum typo geral de fachada para determinadas ruas, prohibição da pintura de casas com cores berrantes, que devem ser substituidas pelos tons neutros, etc. 
Estabelecendo a systhematização dum plano definitivo de remodelação da cidade, o presidente Juvenal Lamartine e o Prefeito Omar O'Grady, a quem Natal já deve os seus mais importantes melhoramentos modernos, terão prestado a esta capital um serviço cuja importancia só o tempo será capaz de mostrar.

PORTINHO, Carmem V. A remodelação de Natal. A República, n.160, Natal, p.02, 13 jul. 1930.

(Communicado da Agencia Brasileira de Carmem Velascos Portinho, engenheira civil, representante do Estado do Rio Grande do Norte ao IV Congresso Pan-Americano de Architectura)

Natal, a capital do Rio Grande do Norte, tem tomado, ultimamente, um grande impulso, devido a sua situação privilegiada que della faz um aeroporto de importancia internacional. No actual governo, o presidente Juvenal Lamartine, está envidando todos os esforços para tornar a sua capital digna do seu novo papel.

O projecto de remodelação de Natal, organisado pelo Estado, e pela Prefeitura sob a direcção do prefeito Omar O'Grady, projecto da autoria do architecto Giacomo Palumbo, foi exposto na Exposição Pan-Americana annexa ao Congresso Pan-Americano de Architectura.

O projecto de remodelação inclue as seguintes divisões de uma cidade moderna: bairro commercial, bairro residencial, bairro jardim, bairro operario, porto maritimo e aeroporto. $\mathrm{O}$ projecto visa alem do embellezamento, a systematização e, alem da esthetica, a possibilidade de execução.

O bairro commercial fica localisado na vizinhança do porto, na cidade baixa. As principaes modificações consistem em rasgar maior numero de avenidas parallelas aos caes, arborisadas e de largura sufficiente para o movimento commercial. Outro ponto focalisado é o augmento das vias de accesso para outras partes da cidade. Neste buario será aproveitado o maximo do que já existe.

O porto de Natal está sendo construido pelo illustre engenheiro Decio da Fonseca. Foram feitas obras de dragagem, aprofundamento e delimitação dos canal, removidos obstaculos, fixadas as dunas, feito um ancoradouro muito vasto e um caes, apparelhado de trilhos e armazens que permitte a atracação dos navios de maior calado.

$\mathrm{Na}$ zona administrativa a remodelação consiste em edificar predios condignos para as repartições publicas entre as quaes o Hospital de Crianças, já terminado, a Saude Publica, etc. A architectura escolhida é a moderna.

O actual bairro residencial de Natal, denominado Petropolis-Tyrol, localisado na cidade alta já está cortado por largas avenidas e nelle se encontram as mais bellas residencias de Natal. Estão terminados, de accordo com o Plano de remodelação o stadium Juvenal Lamartine, o maior do Norte do Brasil. O prado de corridas e o Aero-Club do RN, com campo de pouso e escola de aviação civil. Foram reservados espaços livres nos quaes serão construídos recreios activos e praças publicas. Os jardins destinados aos recreios activos para crianças, serão apparelhados de accordo com a orientação moderna com balanços, gangorras, jogos, tanques de vadesção, etc.

Na zona que fica entre o rio Potengy, que banha Natal e o oceano Atlantico será creado um bairro jardim novo, em moldes semelhantes aos inglezes. As construcções feitas nesse bairro obedecerão a rigorosos canones de urbanismo. Será feito o "zoning" moderno, sendo evitada a super-lotação e sendo os habitantes convidados a se pronunciarem sobre a administração do seu bairro, fixando o número e a localização de lojas e armazens. Largas avenidas serão rasgadas, indo terminar no Boulevard de contorno que parte do caes do porto, margina o rio e o Oceano. 
Todas as casas de operarios existentes junto ao caes, na entrada da cidade e em terrenos baldios serão demolidas, sendo construido um bairro operario inteiramente novo, um pouco afastado do centro. Os habitantes receberão como indemnisação um lote de terreno e uma planta para a edificação de um lar simples de accordo com as pessoas da familia e terão outras facilidades. O bairro operario também será um bairro jardim, havendo uma faixa de terreno em cada lote para plantação em frente da casa.

$\mathrm{Na}$ remodelação de Natal serão aproveitados os monumentos historicos e as bellezas naturaes. As lagôas existentes no perimetro urbano serão transformadas em piscinas. $\mathrm{Na}$ praças Del Prete será colocada a columna romana offerecida a Natal pela Italia, em commemoração de raid Roma-Natal.

O Instituto Historio e Geographico foi convidado a se pronunciar sobre a nomenclatura das avenidas, praças e ruas devendo os nomes serem escolhidos entre os das antigas tribus de indios do territorio estadoal, vultos historicos e personalidades, cujos nomes se acham ligados a historia norte riograndense.

A prefeitura está cuidando [...] de estabelecer um horto para a arborisação das ruas e distribuição de mudas aos habitantes dos bairros jardim.

O Aero-porto de Natal está sendo projectado, de accordo com a orientação do presidente Lamartine.

PORTINHO, Carmem V. Os progressos constantes da aviação. A República, Natal, n.85, p.01, 16 abril 1929 (publicado inicialmente no Jornal do Brasil, Rio de Janeiro)

Cada dia se accentua a importancia da aviação para o progresso humano. Arrojando-se atravez do espaço, o avião annulla as distancias, nivella os accidentes geographicos, apaga as differenças de raça e de crença. Zomba das florestas impenetraveis, dos desertos aridos e dos pantanaes insalubres. Com quanto que lhe proporcionem, de longe em longe, um pouso, eleva-se acima de todos os entraves que difficultam as communicações terrestres entre paizes e as differenças que separam homens e nações. É um formidavel factor de progresso a ave de aço que o cerebro humano creou. Estimula o commercio, diffunde a cultura, colloca o moribundo ao alcance da mão salvadora do cirurgião, permitte aos patriotas verdadeiros conhecer, de visu, o semblante da patria amada, estendendo-a ante seus olhos admirados qual carta animada Liga continentes, vincula corações humanos dos recantos mais distantes do mundo em amplexo de cordialidade e de paz.

Trabalhar pelo progresso da viação aérea é nobilitante; é um estimulo ao desenvolvimento da civilisação; é uma das tarefas mais fecundas a que um estadista moderno possa aspirar.

Vários governantes e soberanos o têm comprehendido perfeitamente. O Rei da Belgica, o Principe de Galles, o Chanceller da Allemanha, o Rei do Afghanistão, o proprio General Juan Vicente Gomes, presidente constitucional da Venezuela, todos elles estimulam o desenvolvimento das rêdes aereas. É um dos pontos capitaes do programma do Presidente Hoover, visando o commercio e a confraternisação americana, tanto assim que lhe dará inicio logo no primeiro anno da sua administração.

Nos paizes da velha Europa, onde, entretanto, as communicações terrestres são faceis, os governos estão envidando os maiores esforços em prol da aviação. O Governo britannico instituiu o Ministério do Ar. No Norte e no centro daquelle continente o aeroplano é considerado um dos meios normaes de transporte. As rêdes allemães de passageiros dão lucros consideraveis e o transporte por milha é mais barato e mais seguro do que por estrada de ferro ou auto-omnibus.

Em terras mais novas o progresso inicia-se mais lentamente. Começa nos pontos mais propicios e soffre os impulsos dados pelas personalidades que mais rapidamente acceitam as correntes novas de qualquer natureza que sejam: economicas, politicas e sociaes. A Colombia, por exemplo, cuja capital situada no interior, exigia para ser alcançada tres 
semanas de navegação fluvial pelo rio Magdalena, possue hoje um transito aereo regular. De toda a America do Sul é o paiz que ostenta linha aerea mais aperfeiçoada e de maior movimento.

Entre nós consoante a nossa civilisação littoranea o transito aereo estabeleceu-se em primeiro logar pela costa do paiz. Desde logo ressaltou a importancia reativa de certos pontos, para a aviação. Os grandes "raids" transatlanticos, por sua vez, sublinharam os fócos naturaes.

Desde logo ficou averiguado ser Natal o centro natural da rêde aerea sul americana. Sentinella avançada no oceno, destina-se a capital do Rio Grande do Norte a ser o "Caes da Europa", como o chamou Victor Konder. Na realidade já preenche esta funcção. Todos os "raids" intercontinentais iniciam ou terminam em Natal o vôo sobre o Atlantico.

O governo actual do Rio Grande do Norte, em boa hora confiado a um espirito essencialmente moderno, o comprehendeu admiravelmente. Cumprindo a missão verdadeira dos dirigentes, que é a de estimular as correntes naturaes do progresso economico e sociologico, muito está fazendo para accelerar o progresso da aviação.

A todos os visitantes alados, que vêm conhecer a formosa terra brasileira, naquelle progressivo recanto nordestino, recebe o Presidente Lamartine com amplexo fraternal. Proporciona as emprezas capazes de estimular o progresso brasileiro pelo melhoramento dos transportes, as facilidades que lhes permitem desenvolver actividade proficua. Natal, além de ser porto predestinado possue varios campos de aterissagem. O Aero-Club do Rio Grande do Norte, que o dr. Juvenal Lamartine preside, é uma instituição capaz de ser assemelhada aos grandes clubs aereos norte-americanos, que além de funcções technicas, cumpre a missão social de estabelecer o contacto entre a aviação e a vida diaria da população.

Emquanto muitos estados brasileiros não possuem um só campo de aterissagem, o interior do Rio Grande do Norte, cuja area é, entretanto, bem pequena, já ostenta campos em muitos municipios, campos estes constituidos pelo processo moderno da cooperação entre o Estado, o municipio e a iniciativa particular. Todas essas innovações são devidas ao enthusiasmo, á actuação directa do Presidente Juvenal Lamartine, cuja comprehensão do papel da aviação não é theorica, mas se evidencia de modo pratico, pois pessoalmente viaja em aeroplano, estuda os aspectos technicos da viação aerea e inaugura os campos.

Por isso mesmo tem despertado a sua actividade o interesse não só no Brasil, mas principalmente no estrangeiro. O Conde de La Vaux, presidente do Aero-Club da França e da Federação Aeronautica Internacional, tece encomios ás verdadeiras transformações operadas pelo esforçado presidente. O capitalista argentino e enthusiasta da aviação, Henrique Beneditti, que ora se acha no Brasil, preparando o "raid" Buenos Ayres-Sevilha, que custeará em parte, é da mesma opinião. O Conde de La Vaux, enaltece a importancia de Natal como centro aereo, dizendo que será a chave dos grandes systemas aereos americanos, a encruzilhada de todas as linhas-tronco, sobrepujando talvez aos centros norte-americanos, pois por Natal passarão além das linhas transatlanticas, as linhas norte-sul e as linhas de penetração em busca do Pacifico. É brilhante o futuro que o destino reserva á capital potyguar. E, para tornar-se apta a desempunhal-o teve a ventura de encontrar á frente do Governo na phase inicial, sempre difficil, um espirito moderno, dotado de descortino e tenacidade, emfim um verdadeiro realizador.

Fazemos votos de que o exemplo do Rio Grande do Norte, venha frutificar, em todo o Brasil. 


\section{Excerto do Relatório de 1930 do prefeito Omar O'Grady}

O'GRADY, Omar. Relatorio apresentado à intendencia municipal de Natal, em 30 de janeiro de 1930. Natal: Imprensa Official, 1930.

\section{PLANO DE SYSTEMATIZAÇÃO DA CIDADE}

De acordo a resolução n. 304 de 6 de abril de 1929, confiei ao architecto Giacomo Palumbo a elaboração de um plano geral de systematização da cidade nas condições do contracto lavrado em 22 de Abril de 1929 e que juntamos nos annexos.

Era este plano, no meu pensa, de uma necessidade inadiável.

Com as licções da falta de previdência e dos projectos sem a preoccupação do futuro que as nossas cidades brasileiras nos têm dado; com o exemplo animador do que se vem fazendo em relação a "planos de cidades" nos outros paizes cultos, principalmente nos Estados Unidos, aonde quase toda cidade tem o seu "máster plan"; com o despertar de uma phase de progresso na nossa cidade e tendo em vista a irregularidade e já insuficiência do nosso actual systema de arruamentos de par com o muito que é possível aproveitar da nossa natureza, não me parece justiicável tornando-se cada vez mais difícil e mais dispendiosa uma solução futura.

Não se trata de um projecto de realisação immediata envolvendo despezas centenas de vezes maiores do que as nossas possibilidades actuaes, mas apenas, do que delineamento de um plano geal de previsão estabelecendo normas dentro das quaes a cidade deverá systematizarse e extender-se. A sua execução já est' 'a sendo iniciada ao passo que o plano vae sendo elaborado, e poderá ser concluído dentro de dez, vinte, cincoenta, cem ou mais annos dependente da associação destes três factores: recursos, persisstencia e continuidade de acção administrativa, tempo.

É do factor tempo, entretanto, de que mais depende a execução de um plano de systematização de cidade. Com o tempo novos meios de financiamento serão forçosamente adaptados, e teremos de lançar mão do credito, da espropriação marginal e das taxas de beneficio, considerando-se tudo de um ponto de vista commercial, de modo que a necessidade geral prefiram sempre ao interesse privado. Somente com o tempo conseguiremos o que no Brasil de hoje ainda quase que não existe; a continuidade de acção administrativa. Mas o tempo há de chegar em que se execute um programma de interesse geral atravez de varias administrações, dividido methodicamente por exercícios financeiros, sem a preocupação das inaugurações apressadas dentro dos quatriênios governamentaes que parecem se preocuparem menos com o valor da obra construída do que com as placas de bronze commemorativas solenimente inauguradas. É com o tempo, afinal que mais economicamente se consegue a realisação da modificação ou systematização de um plano de cidade. É apenas necessário esperar que todas as construcões novas obedeçam aos alinhamentos e condições do projecto, e não permittir- sem-excepção- que reconstruções, modificações ou accrescimos sejam feitos em prédios que não estejam de accordo com estes alinhamentos.

Pelo clichê annexo mostrando a parte já projectada do plano de systematização da cidade, comprehendendo desde o forte dos reis Magos, ao norte, até á rua Jundiahy e seus prolongamentos, ao sul temos uma idéias da importância do trabalho que está em andamento.

Partindo da rua Silva Jardim verificamos que o plano ao norte desta artéria representa projecto novo. Sem preocupação de aproveitamento de arruamento existentes, enquanto que a parte ao sul da referida rua representa mais ou menos aproveitamento do velho plano da cidade com sas modificações imprescindíveis, algumas mesmo radicaes, como, por exemplo, o alargamento da tua do commercio para $12, \mathrm{~m} 00$, a construção de uma avenida de 16,m00 a partir da rua Silva Jardim conquistando terreno ao rio Potengy, o prolongamento da Avenida Tavares de Lyra até á cota cico, rectificação dos alinhamentos da actual Cathedral, 
concordância da praça João Maria com a rua Pedro Soares e o alargamento do cruzamento desta rua com a Avenida Rio Branco.

Uma critica das mais intelligentes e opportunas feitas ao plano foi de que estavam havendo uma preocupação muito grande com o aproveitamento dos alinhamentos existentes. De facto, tem razão de ser esta critica. No entanto ao ponto de prejudicar os imperativos, para o nosso caso, da orientação, da circulação das necessidades futuras do trafego de vehiculos automotores, nem mesmo da esthetica dos planos de cidade. O que não há duvida, entretanto, é que o padrão ou o ideal para planos de cidades de um milhão de habitantes a mais não poderá ser o mesmo para o nosso caso. E mais vale, aqui, darmos inicio a um plano de exeqüibilidade possível do que cuidarmos de um plano puramente ideal, inteiramente incompatível com os nossos recursos. O que é necessário é não se permitir que a cidade continua a crescer da forma em que tem crescido ata hoje. E a execução do plano, embora modesto, que está sendo projectado bem vale mais do que a expectativa de largas possibilidades futuras que permitam o inicio da realização de um plano ideal. E preciso darmos inicio imediato á execução do plano antes que o aggravamento de certos factores encareça, difficulte ou mesmo quase impossibilite a sua solução no futuro.

No clichê vemos assignalada uma curva de nível que corresponde á cinco referida ao zero do maregrapho (approximadamente o baixamar mínimo) estando indicada em cor mais escura a parte acima desta cota e em cor mais clara a parte mais baixa.

Os pontos de mais importância de ordem geral, nesta parte do plano são os seguintes: o proporcionamento de quatro accessos entre o bairro baixo e a cidade alta, em vez de um apenas, existente hoje; o estabelecimento de um bairro jardim na zona hoje conhecida pelo nome de Limpa; a construção de um boulevard de contorno partindo da cidade baixa, de perto do caes do porto, marginando a principio o rio Potengy, depois contornando a cidade jardim, e por fim, marginando o Oceano até ás praias do Meio e da Areia Preta; a construcção de uma avenida em seguida ao caes do porto, conquistando terreno ao rio Potengy, de modo a poder a cidade offerecer um aspecto agradável para o porto.

É agradável registrar o facto de que Natal é uma das poucas cidades no Brasil que estão cuidando seriamente dos planos de systematização, como problema de ordem geral, em contraste com os projectos parciaes sem a preoccupação do conjunto. O Rio de Janeiro com a administração Prado Junior deu o exemplo de que os problemas de urbanização só podem ser considerados do ponto de vista do conjuncto da cidade e tomando em seria consideração o seu desenvolvimento futuro. Os projectos isolados para beneficiar certas e determinadas zonas de uma cidade sem a preocupação do seu conjuncto e das suas necessidades futuras, devem ser considerados como erros graves. A cidade de Victoria é a outra cidade brasileira que tem comprehendido a necessidade a de resolver o seu problema de systematização. Desde a administração Henrique de Novaes, que projectou um intelligente plano geral de systematização e extensão para Victoria, até hoje, tem esta cidade se preoccupado com o seu problema de urbanização. Agora mesmo o governo do Estado do Espírito Santo acaba de nomear uma "commissão de Melhoramentos da Capital", talvez organização semelhante ás "City Plan Commissions", estes dispositivos utilíssimos de administração das modernas e progressistas cidades americanas. É ainda, motivo para satisfação de nossa parte sabermos que esta commissão de Victoria está sendo custeada pelo governo do Estado, em vista da insufficiência de recursos da Prefeitura de Victoria para financia-la, enquanto que entre nós a Prefeitura, só, está levando a effeito os trabalhos de seu plano de systematização sem qualquer auxilio. E a renda de Victoria vae a mais de dois mil contos annuaes, enquanto que a nossa ainda não attinge a mil. 


\section{Resolução municipal n. 304, de 6 de Abril de 1929}

\section{RESOLUÇÃO N. 304}

Autoriza a contractar um plano de systematização da cidade.

O Prefeito Municipal de Natal - Faço saber que a Intendencia municipal de Natal decreta e eu sanciono a presente resolução:

1.1 - Fica o Prefeito autorizado a contractar com pessoa idonea e technica, um plano de remodelação da cidade de Natal.

1.2 Para occorrer as despezas com os trabalhos, fica aberto um credito especial de $\mathrm{R} \$$. 100:000\$000. Sendo 30:000\$000 em moeda corrente da Republica e 70:000\$000 em apolices da Divida Publica Municipal, as quaes vencerão o juro anual de oito por cento pagavel semestramente nos mezes de Janeiro e julho de cada anno e seráo recebidas em pagamentos de impostos municipaes na razão de 20 sobre a importancia a pagar com excepção das contribuições da renda de apropriação especial.

Art. 3 - Revogam-se as disposições em contrario.

Prefeitura Municipal de Natal em 6 de Abril de 1929.

\section{(aa) Omar O Grady}

Prefeito

Mario Eugenio Lyra

Diretor do Expediente

\section{Termo do contrato entre a Prefeitura de Natal e o arquiteto Giacomo Palumbo}

Termo de contrato que fasem de uma parte, a Prefeitura Municipal de Natal, por seu Prefeito, e de outra, o engenheiro Giacomo Palumbo, para a execução de um plano de urbanisação de Natal.

Aos vinte e dois dias do mez de Abril de mil novecentos e vinte e nove, nesta cidade de Natal, Capital do Estado do Rio Grande do Norte, no gabinete do Prefeito Municipal, presente o Prefeito, Engenheiro Omar O'Grady, o engenheiro Archicto Giacomo palumbo, e as testemunhas abaixo assignadas, foi declarado pelo Sr. Prefeito que, de accordo com a Resolução n. 304 de 6 de Abril de 1929, vinha contractar com o citado Sr. Giacomo Palumbo a execução de um plano geral e definitivo de urbanismo para a cidade de Natal, para uma população até cem mil habitantes mediante as clausulas seguintes:

\section{I}

O contractante architecto Giacomo Palumbo, se compromette a, dentro do praso de um anno, a contar desta data, executar e entregar a Prefeitura desta Capital, um plano geral e definitivo da cidade de Natal, de accordo com os ultimos preceitos de urbanismo para uma população até cem mil habitantes e em condições de ser o mesmo plano desenvolvido ou irradiado de modo a poder acompanhar o futuro progresso da cidade.

II

O mesmo architecto obriga-se a fazer por sua conta o serviço de desenhos e estudos in locus.

III

O trabalho a que em virtude do presente contracto se obriga o architecto contratante, constará:

a) de uma planta do projecto da cidade, em pranchas, em papel cançon reforçado á tela, com referencias aos actuaes alinhamentos e costruções, em escala de 1:1000, em aquarella 
polychromia, com projecções de sombras, comprehendendo os quarteiròes administrativo, commercial, industrial, a cidade recreio e os bairro residencial e operario. Esta planta geral do projecto, em escala de1:1000, abrangerá toda a area limitada ao Norte pelo projecto da cidade recreio no local actualmente denominado "Limpa", a Leste pelo Oceano Atlantico, desde o Forte dos Reis Magos, até a Praia da Areia Preta: ao Sul pela Avenida 16 e seu prolongamentos até o Rio Potengy: á Oeste pelo Rio Potengy, desde o prolongamento da Avenida 16 até o Forte dos Reis Magos. Nesta mesma planta serão indicadas a localisação da illuminação publica, viação urbana, arborisação, passeios, monumentos, abrigos, jardins, e praças publicas, locaes para feiras, mercados, matadouros, cemiterios e demais estabelecimentos municipaes.

b) perfiz transversaes em escalas de 1:100, de todos os typos de ruas e avenidas consideradas no projecto.

IV

O projecto a ser elaborado deverá harmonisar as condições de esthetica e preceitos de urbanismo com os interesses da Prefeitura, de modo a reduzir a um minimum as despesas de desapropriação, movimentos de terra, e de obras de arte.

$\mathrm{V}$

Ficará á cargo da Directoria de Obras Municipaes o recebimento dos trabalhos constantes da clausula III, executados de accordo como estabelecido na clausula IV.

VI

Os serviços de levantamentos topographicos, que por ventura forem necessarios, além dos já existentes, e que constam da planta topographica em escala de 1:2000, com curvas de nivel de 2 em 2 metros, que servirá de base para o projecto a ser elaborado, serão feitos pela Prefeitura.

VII

A Prefeitura pagará ao contractante pela realisaçào dos serviços contractados a importancia de R\$. 100:000\$000 (cem contos de reis), sendo 70:000\$000 (setenta contos de reis em apolices da divida publica municipal, a juros de oito por cento ao anno, e R\$. 30:000\$000 (trinta contos de reis), em moeda corrente da Republica, em trez prestações a saber: a) 10:000\$000 em dinheiro e 23:000\$000 em apolices, no acto da assignatura deste termo: b) igual importancia em dinheiro (dez contos de reis) e vinte e trez contos de reis em apolices no acto da apresentação e entrega dos trabalhos a que se refere a letra b da clausula III: C) ainda igual quantia em dinheiro (dez contos de reis), e vinte e quatro contos de reis em apolices no momento da entrega dos ultimos detalhes em escala de 1:100.

VIII

A prefeitura obriga-se pela satisfação do pagamento de qualquer imposto a que estiver sujeito o presente contracto.

E para constar, mandou o Sr. Prefeito lavrar o presente contracto que assina com o contractante e as testemunhal que a tudo foram presentes. E eu Mario Eugenio Lyra, Director do Expediente da Prefeitura Municipal o escrevi.

Natal, 22 de Abril de 1929.

\section{a.a) Omar O Grady}

Giacomo Palumbo

Testemunhas - Manoel Florencio de Almeida Cascudo e João Lima. 